UNIVERSIDADE DE SÃO PAULO

ESCOLA DE ENGENHARIA DE SÃO CARLOS

INSTITUTO DE FÍSICA DE SÃO CARLOS

INSTITUTO DE QUÍMICA DE SÃO CARLOS

\title{
AVALIAÇÃO DE CAMADAS DE CARBONETOS E DE BORETOS \\ PRODUZIDAS NOS AÇOS AISI H13 E D2 POR MEIO DE TRATAMENTOS \\ TERMO-REATIVOS
}

CARLOS KLEBER NASCIMENTO DE OLIVEIRA

São Carlos

2006 


\section{AVALIAÇÃO DE CAMADAS DE CARBONETOS E DE BORETOS PRODUZIDAS NOS AÇOS AISI H13 E D2 POR MEIO DE TRATAMENTOS TERMO-REATIVOS}

Carlos Kleber Nascimento de Oliveira

Tese apresentada à Área Interunidades em Ciência e Engenharia de Materiais, da Universidade de São Paulo, como parte dos requisitos para obtenção do título de Doutor em Ciência e Engenharia de Materiais.

Orientador: Prof. Assoc. Dr. Luiz Carlos Casteletti

São Carlos 
Membros da Comissão Julgadora da Tese de Doutorado de CARLOS KLEBER NASCIMENTO DE OLIVEIRA, apresentada a Área Interunidades em Ciência e Engenharia de Materiais, da EESC-IFSC-IQSC, Universidade de São Paulo, em 06/04/2006.

\section{COMISSÃO JULGADORA:}

Prof. Dr. Luiz Carlos Casteletti - Orientador (EESC/USP)

Profa. Dra. Lauralice de Campos Franceschini Canale (EESC/USP)

Profa. Dra. Maria Clara Filippini lerardi (UNICAMP)

Prof. Dr. Tomaz Toshimi Ishikawa (UFSCar)

Prof. Dr. Claudemiro Bolfarini (UFSCar) 
Aos meus pais, José Nicácio e Francisca, pelo incentivo, apoio e amor, desde o começo. 


\section{AGRADECIMENTOS}

- Ao Programa de Pós-graduação Interunidades em Ciência e Engenharia de Materiais, EESC/IFSC/IQSC, USP, pela oportunidade e apoio.

- Ao CNPq, pela concessão da bolsa de estudo, e financiamento da pesquisa e de participação em eventos.

- À Universidade Regional do Cariri-URCA pela liberação durante o período do desenvolvimento do presente trabalho.

- Ao Prof. Dr. Luiz Carlos Casteletti, pela orientação, incentivo, amizade e ensinamentos.

- A minha mulher Clara, e a minha filha Marina, pelo companheirismo e alegria proporcionados neste período.

- Ao grande camarada Celso Pacheco, pelo apoio e amizade.

- Ao grande amigo Maia, que foi também um colaborador na execução de parte deste trabalho.

- Aos amigos Rosamel, Kleber Figueiredo, Omar, Cristina, Danilo, Luciana, Rodrigo, pela excelente convivência e cooperação.

- Aos meus grandes amigos de São Carlos, Marina Bezerra, Elton, Luciana Abdo, Luciana Montanari, Ronaldo Travassos e Isabel Brandão.

- Aos professores Dr. Antônio Carlos Hernandes e Dr. Waldeck Bose Filho, pelos ensinamentos em sala de aula e cordialidade.

- À Profa. Dra. Lauralice Canale, pelo uso de equipamentos utilizados em alguns experimentos.

- Aos funcionários João, Pedro e George, que sempre colaboraram nas atividades de laboratório, e em especial a Eliezer (Tico), pelo grande auxílio na preparação de corpos de prova e execução de alguns tratamentos, e a Silvânio, pela realização de análises químicas de materiais utilizados. 
- Às funcionárias do Departamento de Eng. de Materiais Regina, Ana, D. Elza, Eliete, Mazé, e da Coordenação do Programa, Érica, Wladerez e Cristiane, que sempre se mostraram prestativas.

- Ao funcionário do Laboratório de Microscopia Eletrônica do IQSC/USP, Carlos Bento e ao Prof. Dr. Germano Tremiliosi, pelas análises de MEV/EDS.

- Ao Eng. Nelson Medinos e à empresa LECO Instrumenta Ltda., pelas análises de GDOS.

- Aos funcionários das bibliotecas Central e do IFSC, pela grande ajuda. 


\section{SUMÁRIO}

LISTA DE FIGURAS

LISTA DE TABELAS vii

LISTA DE SIGLAS viii

LISTA DE SÍMBOLOS $\quad$ ix

RESUMO $\quad x$

ABSTRACT

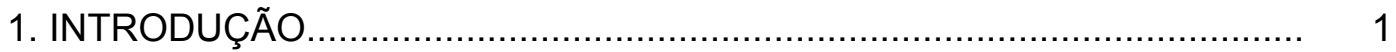

2. REVISÃO BIBLIOGRÁFICA ................................................................ 5

2.1. Introdução........................................................................ 5

2.2. Tratamentos superficiais.............................................................. 6

2.3. Tratamentos termo-reativos de deposição e difusão (TRD)............... 9

2.4. Tratamento de Boretação.......................................................... 17

2.5. Modos de desgaste dos materiais............................................. 21

2.6. Ensaio de desgaste micro-abrasivo................................................... 25

3. PROCEDIMENTO EXPERIMENTAL ................................................ 32

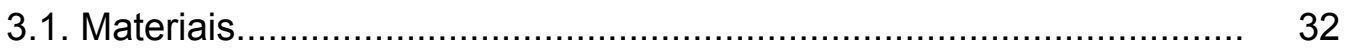

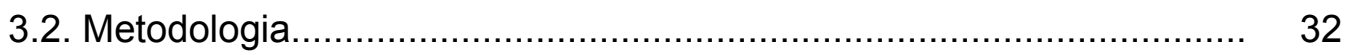

3.2.1. Determinação das composições químicas dos aços H13 e D2....... 34

3.2.2. Determinação das composições químicas dos ferros-ligas e do

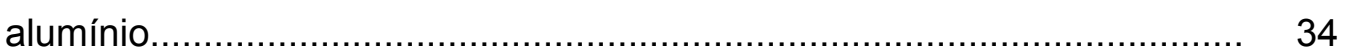

3.2.3. Obtenção dos pós de ferros-ligas................................................... 34

3.2.4. Usinagem dos corpos de prova e confecção dos cadinhos............. 34

3.2.5. Têmpera e revenido dos aços AISI H13 e D2 ............................... 35 
3.2.6. Nitretação lônica do aço AISI H13 .............................................. 35

3.2.7. Tratamentos termo-reativos em banhos de bórax......................... 36

3.2.8. Caracterização das amostras....................................................... 37

3.2.8.1. Microscopia ótica............................................................... 37

3.2.8.2. Microscopia eletrônica de varredura (MEV) com espectrometria de dispersão de energia (EDS)...................................................... 37

3.2.8.3. Difração de raios-X......................................................... 38

3.2.8.4. GDOS (glow discharge optical emission spectroscopy).............. 38

3.2.8.5. Medições das espessuras das camadas.................................... 39

3.2.8.6. Microdureza Vickers................................................................. 39

3.2.8.7. Ensaio de adesividade das camadas........................................ 40

3.2.8.8. Ensaio de desgaste em micro-escala...................................... 40

3.2.8.8.1. Ensaio de desgaste em micro-escala com a "esfera livre"........ 40

3.2.8.8.2. Ensaio de desgaste em micro-escala com a "esfera fixada"..... 42

4. RESULTADOS E DISCUSSÃO.......................................................... 45

4.1. Composições químicas dos aços AISI H13 e D2 .............................. 45

4.2. Análises por microscopia ótica e difração de raios-X dos aços AISI

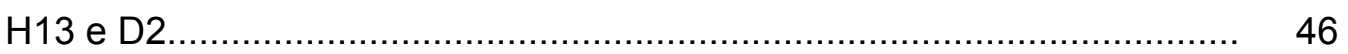

4.3. Nitretação iônica do aço AISI H13............................................... 48

4.4. Tratamentos termo-reativos em banho de bórax.............................. 49

4.4.1. Tratamentos em banho de bórax contendo ferro-nióbio / alumínio.

4.4.2. Tratamentos em banho de bórax contendo ferro-vanádio / alumínio

4.4.3. Tratamentos em banho de bórax contendo ferro-titânio / alumínio

4.4.4. Tratamentos em banho de bórax contendo ferro-titânio / ferronióbio / alumínio

4.4.5. Tratamentos em banho de bórax contendo apenas alumínio.

4.4.5.1. Boretação do aço AISI H13 .................................................. 66

4.4.5.2. Boretação do aço AISI D2 ........................................................ 69

4.4.6. Análises químicas pontuais por meio de MEV/EDS das camadas de boretos produzidas nos aços AISI H13 e D2. 
4.4.6.1. Análises químicas pontuais das camadas boretadas produzidas no aço AISI H13

4.4.6.2. Análises químicas pontuais das camadas boretadas produzidas no aço AISI D2

4.4.7. Análises das camadas de boretos por meio da técnica de GDOS ("Glow Discharge Optical Emission Spectroscopy").

4.4.7.1. Análise de GDOS das camadas de boretos produzidas no aço AISI H13

4.4.7.2. Análise de GDOS das camadas de boretos produzidas no aço AISI D2

4.4.7.3. Análise das relações Fe/B das camadas de boretos produzidas nos aços AISI H13 e D2 89

4.5. Microdureza Vickers das camadas de carbonetos 90

4.6. Microdureza Vickers das camadas de boretos 92

4.7. Aderência das camadas de carbonetos e de boretos 95

4.8. Resistência ao desgaste em micro-escala das camadas de carbonetos e de boretos 97

4.9. Avaliação das superfícies de desgaste

5. CONCLUSÕES

6. REFERÊNCIAS BIBLIOGRÁFICAS. 


\section{LISTA DE FIGURAS}

Figura 2.1 - Microdureza Vickers de camadas obtidas por diferentes tratamentos superficiais

Figura 2.2 - Variação de durezas de diferentes tipos de camadas em ciclos de aquecimentos e resfriamentos

Figura 2.3 - Esquema do mecanismo de formação da camada de carboneto no processo TD

Figura 2.4 - Relação entre as energias livres de formação de carbonetos e de óxidos de elementos adicionados a um banho de bórax e os tipos de camadas produzidas em um aço alto carbono, a $1000^{\circ} \mathrm{C}$

Figura 2.5 - Espessuras das camadas de VC formadas no aço W1 tratado em um banho de bórax contendo $20 \% \mathrm{Fe}-\mathrm{V}$, em diversas temperaturas

Figura 2.6 - Esquema do modo de desgaste abrasivo a dois corpos 22

Figura 2.7 - Esquema do modo de desgaste abrasivo a três corpos

Figura 2.8 - Filme aderido à superfície de desgaste caracterizando o modo de desgaste adesivo

Figura 2.9 - Diagrama esquemático do ensaio de desgaste micro-abrasivo com a esfera "livre"

Figura 2.10 - (a) Diagrama esquemático do ensaio de desgaste micro-abrasivo com a esfera "fixada"

Figura 2.11 - Superfície de desgaste típica para o modo de abrasão a dois corpos.

Figura 2.12 - Superfície de desgaste típica do modo de abrasão a três corpos

Figura 3.1 - Componentes utilizados nos banhos de bórax

Figura 3.2 - Fluxograma do processo utilizado na presente pesquisa

Figura 3.3 - Esquema mostrando a medição da espessura de uma camada de boreto, produzida no aço AISI H13

Figura 3.4 - Equipamento utilizado no ensaio de desgaste micro-abrasivo com a esfera "livre" (CALOTEST), mostrando o eixo, a esfera e a amostra

Figura 3.5 - Esquema do aspecto da camada obtido após o ensaio de desgaste micro-abrasivo com a esfera "livre"

Figura 3.6 - Máquina utilizada no ensaio de desgaste em micro-escala, com a esfera "fixada" 
Figura 3.7 - Esquema mostrando a determinação do diâmetro da calota de desgaste em micro-escala.

Figura 4.1 - Micrografia ótica do aço AISI H13 temperado e revenido

Figura 4.2 - Difratograma de raios-X do aço AISI H13 temperado e revenido

Figura 4.3 - Micrografia ótica do aço AISI D2 temperado e revenido

Figura 4.4 - Difratograma de raios-X do aço AISI D2 temperado e revenido

Figura 4.5 - Micrografia ótica do aço AISI H13 nitretado ionicamente

Figura 4.6 - Difratograma de raios-X da camada produzida no aço AISI H13 nitretado ionicamente

Figura 4.7 - Micrografias óticas das seções transversais do aço AISI H13 tratado no banho de bórax contendo $16 \% \mathrm{Fe}-\mathrm{Nb}+3 \% \mathrm{Al} \ldots$

Figura 4.8 - Micrografia ótica da calota formada após ensaio de desgaste microabrasivo, para o aço AISI H13 tratado no banho de bórax contendo $16 \% \mathrm{Fe}-\mathrm{Nb}$ $+3 \% \mathrm{Al}$

Figura 4.9 - Difratograma de raios-X do aço AISI H13 tratado em banho de bórax contendo $16 \% \mathrm{Fe}-\mathrm{Nb}+3 \% \mathrm{Al}$

Figura 4.10 - Aço AISI H13 tratado em banho contendo Fe-Nb, $1000^{\circ} \mathrm{C} / 4 \mathrm{~h}$ : (a) Micrografia eletrônica mostrando a camada, a matriz, constituída de martensita, e a linha de varredura para o aço AISI H13; (b) Varredura em linha por EDS.

Figura 4.11 - Micrografias óticas do aço AISI D2 tratado em bórax fundido contendo $16 \% \mathrm{Fe}-\mathrm{Nb}+3 \% \mathrm{Al}$

Figura 4.12 - Difratograma de raios-X do aço AISI D2 tratado em bórax fundido contendo $16 \% \mathrm{Fe}-\mathrm{Nb}+3 \% \mathrm{Al}$

Figura 4.13 - Aço AISI D2 tratado em banho contendo 16\%Fe-Nb + 3\%AI: (a) Micrografia eletrônica mostrando a camada, a matriz, constituída de martensita e de carbonetos primários, e a linha de varredura

Figura 4.14 - Micrografias óticas do aço AISI H13 tratado em banho de bórax contendo $10 \% \mathrm{Fe}-\mathrm{V}+3 \% \mathrm{Al}$

Figura 4.15 - Difratograma de raios-X da superfície do aço AISI H13 tratado em banho de bórax contendo $10 \% \mathrm{Fe}-\mathrm{V}+3 \% \mathrm{Al}$

Figura 4.16 - Aço AISI H13 tratado em banho contendo 10\%Fe-V + 3\%Al: (a) Micrografia eletrônica mostrando a camada, a matriz, constituída de martensita, e a linha de varredura

Figura 4.17 - Micrografias óticas do aço AISI D2 tratado em banho de borax contendo $10 \% \mathrm{Fe}-\mathrm{V}+3 \% \mathrm{Al}$ 
Figura 4.18 - Difratograma de raios-X da superfície do aço AISI D2 tratado em banho contendo $10 \% \mathrm{Fe}-\mathrm{V}+3 \% \mathrm{Al}$

Figura 4.19 - Aço AISI D2 tratado em banho contendo 10\%Fe-V + 3\%Al: (a) Micrografia eletrônica mostrando a camada, a matriz, constituída de martensita e de carbonetos primários, e a linha de varredura.

Figura 4.20 - (a) Micrografia ótica da camada formada no aço AISI H13, tratado em banho de bórax contendo $10 \% \mathrm{Fe}-\mathrm{Ti}+5 \% \mathrm{Al}$

Figura 4.21 - Difratograma de raios-X do aço AISI H13 tratado em banho de bórax contendo $10 \% \mathrm{Fe}-\mathrm{Ti}+5 \% \mathrm{Al}$

Figura 4.22 - Micrografia ótica mostrando a camada formada sobre o aço AISI D2, tratado no banho $10 \% \mathrm{Fe}-\mathrm{Ti}+5 \% \mathrm{Al}$

Figura 4.23 - Difratograma de raios-X do aço AISI D2 tratado em banho de bórax contendo $10 \% \mathrm{Fe}-\mathrm{Ti}+5 \% \mathrm{Al}$

Figura 4.24 - MEV das amostras tratadas em banho de borax contendo $10 \% \mathrm{Fe}-\mathrm{Ti}+5 \% \mathrm{Fe}-\mathrm{Nb}+3 \% \mathrm{Al}$

Figura 4.25 - Difratograma de raios-X das superfícies dos aços tratados em banho de borax contendo $10 \% \mathrm{Fe}-\mathrm{Ti}+5 \% \mathrm{Fe}-\mathrm{Nb}+3 \% \mathrm{Al}$

Figura 4.26 - Micrografia ótica do aço AISI H13 tratado em banho de bórax contendo $5 \% \mathrm{Al}, 1000^{\circ} \mathrm{C} / 4 \mathrm{~h}$

Figura 4.27 - (a) Micrografia ótica do aço AISI H13 tratado em banho de bórax contendo $10 \% \mathrm{Al}, 1000^{\circ} \mathrm{C} / 4 \mathrm{~h}$

Figura 4.28 - Difratograma de raios-X do aço AISI H13 tratado no banho de bórax contendo $10 \% \mathrm{Al}, 1000^{\circ} \mathrm{C} / 4 \mathrm{~h}$

Figura 4.29 - (a) Micrografia ótica do aço AISI H13 tratado em banho de bórax contendo $15 \% \mathrm{Al}, 1000^{\circ} \mathrm{C} / 4 \mathrm{~h}$

Figura 4.30 - Difratograma de raios-X do aço AISI H13 tratado em banho de bórax com $15 \% \mathrm{Al}, 1000^{\circ} \mathrm{C} / 4 \mathrm{~h}$

Figura 4.31 - Micrografia ótica do aço AISI D2 tratado em banho de bórax contendo $10 \% \mathrm{Al}, 1000^{\circ} \mathrm{C} / 4 \mathrm{~h}$

Figura 4.32 - Difratograma de raios-X do aço AISI D2 tratado em banho de bórax contendo $10 \% \mathrm{Al}, 1000^{\circ} \mathrm{C} / 4 \mathrm{~h}$

Figura 4.33 - Micrografia ótica do aço AISI D2 tratado em banho de bórax contendo $15 \% \mathrm{Al}, 1000^{\circ} \mathrm{C} / 4 \mathrm{~h}$

Figura 4.34 - Difratograma de raios-X do aço AISI D2 tratado em banho de bórax contendo $15 \% \mathrm{Al}, 1000^{\circ} \mathrm{C} / 4 \mathrm{~h}$ 
Figura 4.35 - Micrografia ótica do aço AISI D2 tratado em banho de bórax contendo $15 \% \mathrm{Al}, 800^{\circ} \mathrm{C} / 4 \mathrm{~h}$

Figura 4.36 - Difratograma de raios-X do aço AISI D2 tratado em banho de bórax com $15 \% \mathrm{Al}, 800^{\circ} \mathrm{C} / 4 \mathrm{~h}$

Figura 4.37 - (a) MEV do aço AISI H13 boretado no banho contendo 10\%Fe-Ti $+5 \% \mathrm{Al}, 1000^{\circ} \mathrm{C} / 4 \mathrm{~h}$

Figura 4.38 - Perfis de concentração de Si, V, Mo e Cr na camada de boreto, determinados por EDS.

Figura 4.39 - (a) MEV do aço AISI H13 boretado no banho contendo 15\%Al, $1000^{\circ} \mathrm{C} / 4 \mathrm{~h}$

Figura 4.40 - Perfis de concentração de Si, V, Mo e Cr na camada de boreto, determinados por EDS

Figura 4.41 - (a) MEV do aço AISI D2, boretado no banho contendo $10 \% \mathrm{Fe}-\mathrm{Ti}$ $+5 \% \mathrm{Al}, 1000^{\circ} \mathrm{C} / 4 \mathrm{~h}$

Figura 4.42 - Perfis de concentração de Si, V, Mo e Cr na camada de boreto, determinados por EDS

Figura 4.43 - (a) MEV do aço AISI D2, boretado no banho com adição de $15 \% \mathrm{Al}, 1000^{\circ} \mathrm{C} / 4 \mathrm{~h}$;

Figura 4.44 - Perfis de concentração de Si, V, Mo e Cr na camada de boreto, determinados por EDS

Figura 4.45 - (a) MEV do aço AISI D2, boretado no banho com adição de $15 \% \mathrm{Al}, 800^{\circ} \mathrm{C} / 4 \mathrm{~h}$

Figura 4.46 - Perfis de concentração de Si, V, Mo e Cr na camada de boreto, determinados por EDS nos pontos de 1-5

Figura 4.47 - Curvas de GDOS da camada de boreto obtida no aço AISI H13. Banho: $10 \% \mathrm{FeTi} / 5 \% \mathrm{Al}$, à $1000^{\circ} \mathrm{C} / 4 \mathrm{~h}$

Figura 4.48 - Curvas de GDOS da camada de boreto obtida no aço AISI H13. Banho: $15 \% \mathrm{Al}$, à $1000^{\circ} \mathrm{C} / 4 \mathrm{~h}$

Figura 4.49 - Perfis de concentração de boro nas camadas de boretos obtidas no aço AISI H13, em diferentes composições de banhos.

Figura 4.50 - Curvas de GDOS da camada obtida no aço AISI D2. Banho: $10 \% \mathrm{FeTi} / 5 \% \mathrm{Al}$, à $1000^{\circ} \mathrm{C} / 4 \mathrm{~h}$

Figura 4.51 - Curvas de GDOS da camada obtida no aço AISI D2. Banho: $15 \% \mathrm{Al}$, à $1000^{\circ} \mathrm{C} / 4 \mathrm{~h}$

Figura 4.52 - Curvas de GDOS da camada de boreto obtida no aço AISI D2. Banho: $15 \% \mathrm{Al}$, à $800^{\circ} \mathrm{C} / 4 \mathrm{~h}$ 
Figura 4.53 - Perfis de concentração de boro nas camadas de boretos obtidas no aço AISI D2, em diferentes condições de banhos e de tratamentos

Figura 4.54 - Indentações Vickers na superfície do aço H13 substrato (Temperado e revenido), e com diferentes tipos de camadas

Figura 4.55 - Indentações Vickers na superfície do aço D2 substrato (Temperado e revenido), e com diferentes tipos de camada

Figura 4.56 - Perfis de microdureza Vickers das camadas de boretos obtidas no banho contendo $10 \% \mathrm{FeTi} / 5 \% \mathrm{Al}$, à $1000^{\circ} \mathrm{C} / 4 \mathrm{~h}$ : (a) aço $\mathrm{AISI} \mathrm{H} 13$, (b) aço AISI D2

Figura 4.57 - Perfis de microdureza Vickers das camadas de boretos, obtidas no banho contendo $15 \% \mathrm{Al}$, à $1000^{\circ} \mathrm{C} / 4 \mathrm{~h}$ : (a) aço AISI H13, (b) aço AISI D2

Figura 4.58 - Indentações Vickers na interface da camada de NbC com o substrato (aço AISI H13)

Figura 4.59 - Indentações Vickers na interface da camada de VC com o substrato (aço AISI D2).

Figura 4.60 - Indentações Vickers na interface da camada de Fe-B com o substrato (aço AISI D2).

Figura 4.61 - Curvas de desgaste em micro-escala para o aço AISI H13: temperado/revenido (TR) e revestido com camadas de nitretos, carbonetos e boretos

Figura 4.62 - Calotas formadas no aço AISI H13 após ensaio de desgaste em micro-escala, para uma distância de deslizamento de $177 \mathrm{~m}$.

Figura 4.63 - Curvas de desgaste em micro-escala para o aço AISI D2: temperado/revenido (TR) e revestido com camadas de nitretos, carbonetos e boretos

Figura 4.64 - Calotas formadas no aço AISI D2 após ensaio de desgaste em micro-escala, para uma distância de deslizamento de $177 \mathrm{~m}$.

Figura 4.65 - Superfícies de desgaste das camadas, obtidas para uma distância de deslizamento de $177 \mathrm{~m}$

Figura 4.66 - (a) MEV e (b) EDS pontual da superfície de desgaste no aço AISI $\mathrm{H} 13$ temperado e revenido.

Figura 4.67 - (a) MEV e (b) EDS pontual da superfície de desgaste da camada de $\mathrm{NbC}$. Substrato: aço H13

Figura 4.68 - (a) MEV e (b) EDS pontual da superfície de desgaste da camada de NbC. Substrato: aço D2

Figura 4.69 - (a) e (b) MEV e (c) EDS pontual da superfície de desgaste da camada de VC. Substrato: aço H13 
Figura 4.70 - (a) MEV e (b) EDS pontual da superfície de desgaste da camada de boreto. Substrato: aço H13

Figura 4.71 - (a) MEV e (b) EDS pontual da superfície de desgaste da camada boretada. Substrato: aço D2 


\section{LISTA DE TABELAS}

Tabela 2.1 - Características dos processos CVD, PVD e TRD 10

Tabela 2.2 - Propriedades das fases $\mathrm{Fe}_{2} \mathrm{~B}$ e FeB. 19

Tabela 3.1 - Parâmetros da têmpera e do revenido realizados nos aços AISI H13 e D2.

Tabela 3.2 - Parâmetros do tratamento de nitretação iônica realizado no aço AISI H13

Tabela 3.3 - Composições dos banhos usados nos tratamentos termoreativos

Tabela 3.4 - Parâmetros utilizados nos testes de desgaste em micro-escala

Tabela 4.1 - Composições químicas dos aços AISI H13 e D2

Tabela 4.2 - Composição química da liga Fe-Nb

Tabela 4.3 - Composição química da liga Fe-V

Tabela 4.4 - Composição química da liga Fe-Ti

Tabela 4.5 - Composição química do alumínio

Tabela 4.6 - Espessuras das camadas de NbC formadas aços AISI H13 e D2, à $1000^{\circ} \mathrm{C} / 4 \mathrm{~h}$

Tabela 4.7 - Relação Fe/B (em \% atômica) nas camadas boretadas, em função da profundidade da camada

Tabela 4.8 - Microdurezas Vickers $\left(\mathrm{HV}_{0,050}\right)$ dos aços AISI H13 e D2, substratos e revestidos

Tabela 4.9 - Microdurezas Vickers $\left(\mathrm{HV}_{0,50}\right)$ das camadas boretadas obtidas em diferentes composições de banho, à $1000^{\circ} \mathrm{C}$. 


\section{LISTA DE SIGLAS}

AISI - "American Iron and Steel Institute"

CCDM - Centro de Caracterização e Desenvolvimento de Materiais

CVD - Deposição Química de Vapor (“Chemical Vapour Deposition”)

EDS - Espectroscopia de dispersão de energia ("Energy Dispersive X-Ray

Spectroscopy")

EESC - Escola de Engenharia de São Carlos

EFC - Elemento Formador de Carboneto

GDOS - "Glow Discharge Optical Spectroscopy"

HV - Microdureza Vickers

IFSC - Instituto de Física de São Carlos

IQSC - Instituto de Química de São Carlos

MEV - Microscopia Eletrônica de Varredura

PMMA - Poli Metacrilato de Metila

PVD - Deposição Física de Vapor (“Physical Vapour Deposition”)

SMM - Departamento de Engenharia de Materiais, Aeronáutica e Automobilística

TD - "Toyota Diffusion"

TRD - Termo-Reativo de Deposição e Difusão

UFSCar - Universidade Federal de São Carlos 


\section{LISTA DE SÍMBOLOS}
d Diâmetro médio da calota de desgaste
D Diâmetro da esfera
$\mathrm{d}_{1}, \mathrm{~d}_{2} \quad$ Diâmetros da calota de desgaste
$D_{S} \quad$ Distância de deslizamento
e Espessura da camada
$e_{1} \quad$ Espessura da camada medida no microdurômetro com um micrômetro acoplado
$e_{2} \quad$ Espessura da camada determinada por meio do ensaio de desgaste micro-abrasivo
$\mathrm{F}_{\mathrm{N}} \quad$ Força normal de contato
$k$ Constante da taxa de crescimento da camada
$N_{R} \quad$ Número de revoluções da esfera de desgaste
$\mathrm{R} \quad$ Raio da esfera
t Tempo
$t_{s} \quad$ Tempo do experimento
V Volume da calota de desgaste 


\section{RESUMO}

Neste trabalho, camadas de elevadas durezas e resistentes ao desgaste, constituídas de $\mathrm{NbC}$, VC ou Fe-B, foram produzidas nos aços AISI H13 e D2, por meio de tratamentos termo-reativos em banhos de bórax, com adição de $\mathrm{Fe}-\mathrm{Nb}, \mathrm{Fe}-$ $\mathrm{V}, \mathrm{Fe}-\mathrm{Ti}$ e Al. As amostras foram caracterizadas por meio de microscopias ótica e eletrônica de varredura com EDS (espectroscopia de dispersão de energia), difração de raios-X, GDOS ("Glow discharge optical spectroscopy"), microdureza Vickers, e ensaios de adesividade e desgaste em micro-escala. Para os banhos contendo $\mathrm{Fe}-\mathrm{Nb} / \mathrm{Al}$, foram obtidas camadas de $\mathrm{NbC}$ nos dois aços, com espessuras médias de $6,2 \mu \mathrm{m}$, quando produzida no aço AISI H13, e 15,6 $\mu \mathrm{m}$ para o aço AISI D2. No caso do banho com adição de Fe-V/Al, produziram-se camadas de VC, com espessuras médias de 5,8 e 14,2 $\mu \mathrm{m}$, para os aços AISI H13 e D2, respectivamente. As durezas das camadas de $\mathrm{NbC}$ e VC situaram-se na faixa de 2338 a $2471 \mathrm{HV}$. No caso dos banhos contendo $\mathrm{Fe}-\mathrm{Ti}$ e $\mathrm{Al}$ ou apenas $\mathrm{Al}$, foram produzidas camadas de boretos, principalmente $\mathrm{FeB}$ e $\mathrm{Fe}_{2} \mathrm{~B}$, com espessuras variando de 30 a $130 \mu \mathrm{m}$, e durezas médias na faixa de 1583 a $1742 \mathrm{HV}$. Os ensaios de adesividade evidenciaram as excelentes aderências das camadas com os substratos. Todas as camadas apresentaram resistências ao desgaste muito superiores as dos substratos, destacando-se as camadas de $\mathrm{NbC}$ e VC. Os ensaios de desgaste em micro-escala foram realizados sob carga elevada e sem uso de abrasivo, simulando condições de desgaste adesivo-abrasivo, uma vez que inexistem dados a respeito desse comportamento. Com o decorrer do ensaio, o modo de desgaste passou de adesivo para abrasivo, o que foi registrado pela presença de sulcos paralelos e de superfícies polidas nas calotas de desgaste. 


\begin{abstract}
In the present work, hard and wear resistant layers, consisting of $\mathrm{NbC}, \mathrm{VC}$ or $\mathrm{Fe}-\mathrm{B}$, were produced on AISI H13 and D2 steels, by thermo-reactive treatments in borax baths, added with Fe-Nb, Fe-V, Fe-Ti and Al. Samples were characterized by optical and scanning electron microscopy, energy dispersive X-ray spectrometry (EDS), Xray diffraction (XRD), Glow discharge optical spectroscopy (GDOS), Vickers microhardness, and adhesion and micro-scale wear tests. For the baths containing $\mathrm{Fe}-\mathrm{Nb} / \mathrm{Al}$, the layers obtained on both steels consisted of $\mathrm{NbC}$, with an average thickness of $6.2 \mu \mathrm{m}$, when formed on AISI H13 steel, and $15.6 \mu \mathrm{m}$ for the AISI D2 steel. In the case of borax bath added with $\mathrm{Fe}-\mathrm{V} / \mathrm{Al}$, the produced layers contained VC, which had average thicknesses of 5.8 and $14.2 \mu \mathrm{m}$, for the AISI H13 and D2 steels, respectively. The hardness of the $\mathrm{NbC}$ and $\mathrm{VC}$ layers varied from 2338 to $2471 \mathrm{HV}$. In the case of the borax bath containing $\mathrm{Fe}-\mathrm{Ti}$ and $\mathrm{Al}$ or only $\mathrm{Al}$, boride layers were produced, mainly $\mathrm{FeB}$ and $\mathrm{Fe}_{2} \mathrm{~B}$, with depths ranging from 30 to $130 \mu \mathrm{m}$, and average hardnesses varying from 1583 to $1742 \mathrm{HV}$. The obtained layers presented excellent adhesion to the substrates. All layers presented wear resistance superior to the substrates, mainly the $\mathrm{NbC}$ and $\mathrm{VC}$ layers. The micro-scale wear tests were performed under high applied loads and without addition of abrasive, thus simulating adhesive-abrasive wear conditions, as there is no existing data concerning this wear behavior. During the micro-scale wear test, the wear mode changed from adhesive wear to abrasive wear, which was verified by the presence of parallel grooves and smooth surfaces in the wear craters.
\end{abstract}




\section{INTRODUÇÃO}

Cada vez mais acentua-se o desenvolvimento de novos materiais e otimizam-se os processos de fabricação, visando-se ao aumento da produtividade e ao melhoramento da qualidade dos produtos. Os tratamentos superficiais prestamse muito bem para esse fim, uma vez que possibilitam a obtenção de propriedades específicas onde são mais necessárias, como por exemplo, dureza superficial elevada, aliada a uma boa tenacidade da peça como um todo. Assim, o uso de revestimentos adequados pode aumentar a vida útil e melhorar o desempenho de ferramentas de corte e matrizes de forjamento e de injeção, entre outros, e com isso, amenizar a maioria dos problemas existentes nos processos de fabricação mecânica. Vários tratamentos superficiais, dos convencionais aos mais modernos, são utilizados com esta finalidade, como nitretação, carbonitretação, aspersão térmica, deposição química de vapor (CVD), deposição física de vapor (PVD), boretação e tratamentos termo-reativos de deposição e difusão (TRD).

Os tratamentos TRD em banhos de bórax são utilizados com sucesso para produzir camadas de $\mathrm{NbC}, \mathrm{VC}, \mathrm{Cr}_{7} \mathrm{C}_{3}$ e $\mathrm{Cr}_{23} \mathrm{C}_{6}$ em substratos contendo carbono, com níveis de dureza que podem exceder 3000HV (Arai e Harper, 1991). Neste processo, elementos como nióbio, vanádio ou cromo, dissolvidos no banho, combinam-se quimicamente com o carbono do substrato, formando a camada. As espessuras destas camadas geralmente situam-se na faixa de 5 a $15 \mu \mathrm{m}$, dependendo dos parâmetros do processo e da quantidade de carbono no substrato. As camadas produzidas por meio do tratamento TRD apresentam propriedades 
similares as dos revestimentos de TiC, TiN e TiCN obtidos pelos métodos CVD e PVD, em termos de aplicações industriais, sendo que o processo TRD apresenta a vantagem de ser mais simples e ter um custo menor (Arai e Harper, 1991; Arai, 1992).

No processo de boretação obtêm-se camadas com durezas na faixa de 1400 a 2100HV (Ozbek e Bindal, 2002). A camada boretada forma-se pela reação química do boro, fornecido pelo banho, com o metal base. Em aços e em ferro puro geralmente obtêm-se camadas de $\mathrm{Fe}_{2} \mathrm{~B}$ e $\mathrm{FeB}$ (Sinha, 1991). As camadas podem apresentar espessuras de até $380 \mu \mathrm{m}$, dependendo do tempo e da temperatura do processo e da presença de elementos de liga no substrato (Ozbek e Bindal, 2002; Özbek et al., 2002).

Os níveis de dureza das camadas obtidos nos dois processos descritos são superiores aos da dureza de revestimentos obtidos pelos tratamentos de nitretação, cementação e eletrodeposição de cromo. As camadas de boretos e de carbonetos apresentam também baixo coeficiente de atrito, elevada resistência ao desgaste, boa resistência à corrosão e excelente adesão ao metal-base (Sinha, 1991; Arai, 1979; Plumb, 1985).

Tratamentos termo-reativos em banhos de bórax com adição de vanádio, nióbio e cromo, foram desenvolvidos no início dos anos 70, no "Toyota Central Research Institute", Japão, sendo conhecido como o processo TD ("Toyota Diffusion"). No entanto, a utilização de um banho de bórax contendo titânio, que também é um formador de carboneto, ainda não foi devidamente explorada. De acordo com Arai et al. (1987), camadas de carbonetos ou de boretos podem ser obtidas em aços tratados em um banho de bórax com adição de $\mathrm{Fe}-\mathrm{Ti}$, mas resultados experimentais não foram apresentados neste caso. Este tipo de banho foi estudado na presente pesquisa. Investigou-se também o tipo da camada formada em um banho de bórax misto contendo Fe-Nb + Fe-Ti. 
No presente trabalho, amostras dos aços AISI H13 e D2 foram revestidas por meio de tratamentos em banhos de bórax e em seguida foram caracterizadas, utilizando-se técnicas que permitiram determinar as morfologias, as composições químicas e as resistências ao desgaste das camadas. Avaliou-se o comportamento tribológico das camadas de carbonetos e de boretos por meio de ensaios de desgaste em micro-escala. $\mathrm{O}$ ensaio de desgaste micro-abrasivo foi desenvolvido recentemente por Rutherford e Hutchings (1996), e tem como princípio o deslizamento de uma esfera sobre a superfície ensaiada, na presença de um abrasivo. O método, embora seja usado para estudar o comportamento ao desgaste de vários tipos de materiais, principalmente no estudo de revestimentos finos de elevada dureza (Allsopp e Hutchings, 2001; Batista et al., 2002), ainda não foi utilizado para avaliar a resistência ao desgaste de camadas de carbonetos de nióbio e de vanádio. Em relação às camadas boretadas, os resultados encontrados na literatura (Martini et al., 2004-a) não chegaram ao nível de investigação desenvolvido no presente trabalho. Por outro lado, os ensaios de desgaste realizados na presente pesquisa ocorreram em condições de carga elevada e sem o uso de lama abrasiva, que são parâmetros diferentes dos encontrados na literatura (Trezona et al., 1999; Bose e Wood, 2005), induzindo condições de desgaste do tipo adesivo-abrasivo. Os desempenhos ao desgaste em micro-escala das camadas de carbonetos e de boretos foram comparados entre si e também com uma camada nitretada obtida no aço-ferramenta AISI H13.

Os aços ferramentas AISI H13 e D2, utilizados no presente estudo, são os mais usados em suas classes, em diversas operações de fabricação mecânica. Eles apresentam alta temperabilidade, elevada resistência ao amolecimento, baixa distorção na têmpera e boa resistência ao desgaste. O aço-ferramenta para trabalho a quente AISI H13 é usado na confecção de matrizes para forjamento, estampagem a quente e extrusão, moldes de fundição e em ferramentas de corte e 
de furação à quente. O aço-ferramenta para trabalho a frio AISI D2 encontra aplicações em ferramentas de corte, de furação, extrusão a frio, entre outras. Os teores de carbono e de cromo dos aços AISI H13 e D2, foram considerados na seleção desses substratos, uma vez que o carbono exerce influência crucial na formação das camadas de carbonetos, enquanto os dois elementos influenciam na espessura, morfologia e composição das camadas boretadas. Por fim, os aços AISI H13 e D2 apresentam faixas de austenitização comuns, o que possibilitou efetuar os tratamentos de todas as amostras sob as mesmas condições de aquecimento (por exemplo, à $1000^{\circ} \mathrm{C}$ ), e realizar as têmperas diretamente do banho.

O objetivo do presente trabalho consistiu na obtenção de camadas de carbonetos e de boretos nos aços AISI H13 e D2, por meio de tratamentos termoreativos em banhos de bórax, e nas suas caracterizações, principalmente em termos da determinação de suas composições e da avaliação de seus comportamentos quanto ao desgaste em micro-escala, com carga elevada e sem o uso de abrasivos. 


\section{REVISÃO BIBLIOGRÁFICA}

\subsection{Introdução}

Durante a operação em serviço, os moldes para fundição sob pressão são submetidos a elevadas tensões mecânicas induzidas pelo fluxo à alta pressão do metal líquido, e a tensões térmicas decorrentes do contato alternado com o material fundido, em temperaturas superiores a $700^{\circ} \mathrm{C}$. Tais tensões térmicas ocorrem também nas matrizes de forjamento. Essas condições de trabalho são as razões para o rápido desgaste dos moldes e das matrizes, assim como para a formação de trincas superficiais nas áreas de maiores pressões, fatores que desqualificam a ferramenta, comprometendo definitivamente a matriz ou tornando necessária a sua recuperação (Walkowicz et al., 1997; Lee et al., 1996; Quaeyhaegens et al., 1996).

Nas operações de corte dos metais, muitos materiais a serem usinados podem conter partículas ou fases que apresentam durezas muito maiores do que a da peça como um todo. Muitas destas partículas são mais duras do que a matriz do aço ferramenta, mantendo ainda esta dureza a temperaturas elevadas. Tais materiais em condições de trabalho podem causar abrasão na ferramenta sob situações de deslizamento, sendo que na maioria dos trabalhos publicados sobre desgaste de ferramentas, o desgaste de flanco, em particular, é atribuído à abrasão (Sirvio et al., 1982).

Desgaste é um dos problemas mais comumente encontrado na indústria, acarretando a substituição de componentes, consumo de lubrificantes e redução na eficiência das operações, apresentando, portanto, significativa importância econômica (Eyre, 1991). Os principais problemas de desgaste referentes às 
ferramentas de corte, matrizes de forjamento e moldes de fundição podem ser amenizados por meio da utilização de tratamentos superficiais, para a obtenção de revestimentos de elevadas durezas e resistências ao desgaste e baixos coeficientes de atrito (Holmberg, 1992; Subramaniam et al., 1996).

\subsection{Tratamentos superficiais}

O uso de tratamentos superficiais amplia a possibilidade de projetar peças de forma a se obter propriedades específicas aonde são mais necessárias. Assim, uma peça tratada superficialmente pode apresentar um núcleo com resistência mecânica e tenacidade elevadas e ao mesmo tempo ser altamente resistente ao desgaste. Os aços-ferramenta são largamente usados em aplicações industriais como componentes mecânicos, ferramentas de corte, moldes e matrizes, onde a resistência ao desgaste e à corrosão e o coeficiente de atrito são de importância primordial.

A engenharia de superfície, que é definida como um campo que engloba as técnicas e processos usados para induzir, modificar e melhorar o desempenho de superfícies, com respeito ao desgaste, fadiga, corrosão e biocompatibilidade, vem sendo usada cada vez mais para melhorar o desempenho de moldes e matrizes e das ferramentas de corte citadas anteriormente (Subramanian et al., 1996; Sidky et al., 1999). A principal motivação para o uso de revestimentos duros em ferramentas de corte e de conformação, assim como em outros campos da indústria, tem sido a econômica. Por exemplo, revestimentos de TiN podem aumentar a vida da ferramenta em mais de dez vezes (Subramanian et al., 1993).

Outro campo de grande interesse no uso de revestimentos duros é o da estampagem, que é um processo de fabricação largamente utilizado nas engenharias industrial e de precisão. Revestimentos com durezas elevadas aumentam a resistência ao desgaste das ferramentas, ampliando assim a vida útil 
das mesmas e melhorando a qualidade de produtos estampados. Os requisitos fundamentais para um revestimento ser eficaz nestas ferramentas são: boa adesão ao metal base, para suportar as altas cargas e forças de cisalhamento sem destacar-se, dureza e tenacidade elevadas, e baixo coeficiente de atrito contra o material estampado para reduzir o desgaste (Zeng et al., 2000). As técnicas de revestimentos duros que podem ser usadas nas ferramentas de estampagem são as mesmas descritas anteriormente para matrizes e ferramentas de corte.

Dentre as técnicas modernas disponíveis para o melhoramento do desempenho de ferramentas de corte, moldes e matrizes, utilizados na fabricação mecânica, destacam-se os processos de nitretação e carbonitretação iônicas, aspersão térmica, revestimento por solda, implantação iônica, deposição física de vapor (PVD), deposição química de vapor (CVD), tratamentos termo-reativos de deposição e difusão (TRD) e boretação. Os dois últimos, que são os métodos utilizados no presente trabalho, consistem em processos bastante efetivos para a produção de camadas com níveis de dureza que situam-se entre os mais altos alcançados em revestimentos. Como mostrado na figura 2.1, camadas de carbonetos de vanádio ( $\mathrm{VC})$ e de nióbio $(\mathrm{NbC})$ obtidas por tratamentos TRD apresentam durezas similares às durezas do TiC e TiN obtidos por CVD e PVD (Arai e Harper, 1991; Arai, 1992). Na figura 2.1 verifica-se ainda que os níveis de dureza das camadas de boretos de ferro são superiores aos das camadas obtidas pelos processos de nitretação e eletrodeposição.

As camadas de carbonetos e de boretos apresentam durezas relativamente altas mesmo quando submetidas a temperaturas elevadas. Como pode se observar na figura 2.2 (Pág. 9), durezas na faixa de 900 a 1000HV podem ocorrer a uma temperatura de $800^{\circ} \mathrm{C}$. Outra característica importante é que, após exposição à altas temperaturas, as durezas dessas camadas retornam a um nível ainda elevado quando resfriadas até a temperatura ambiente. 


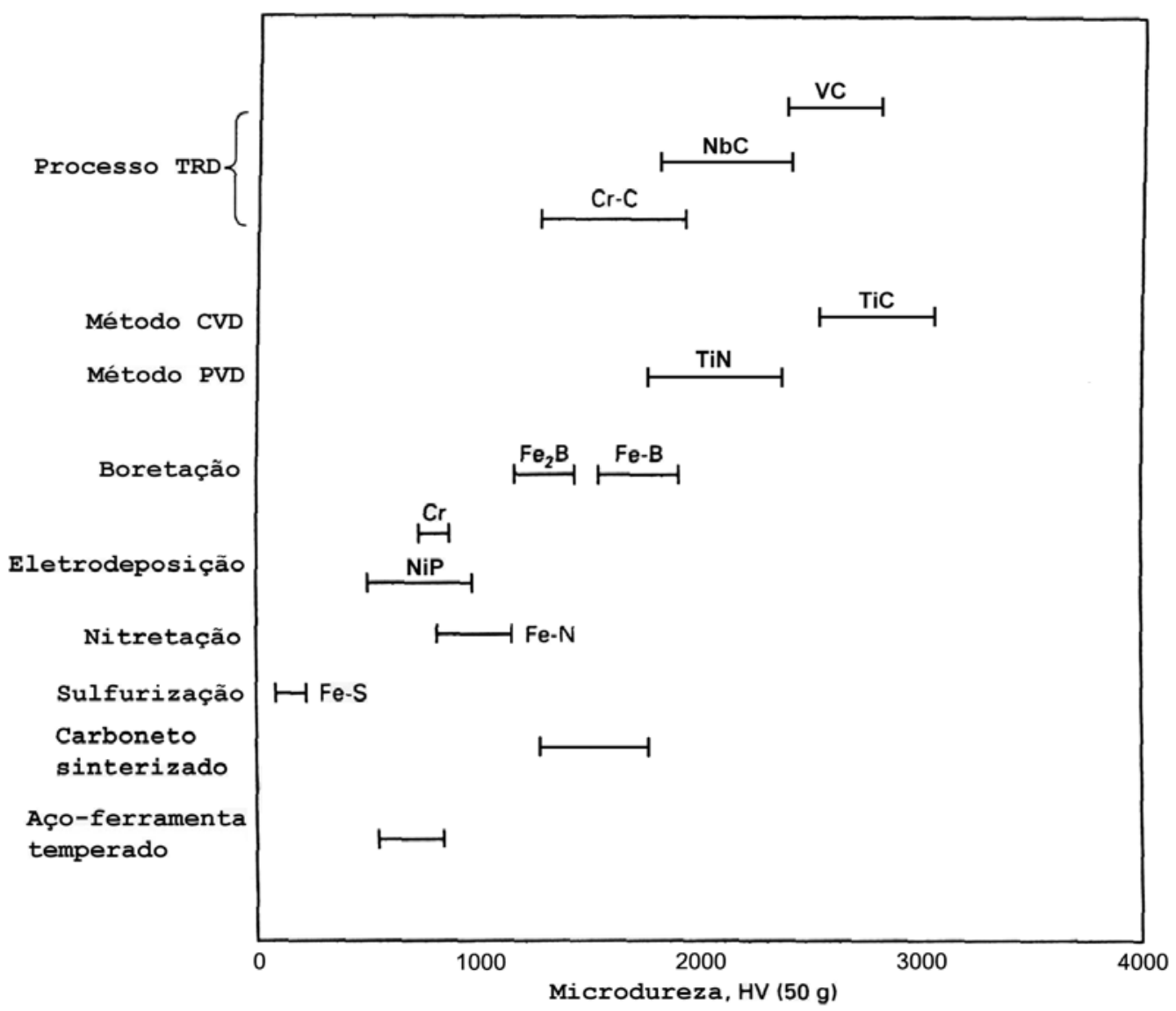

Figura 2.1 - Microdureza Vickers de camadas obtidas por diferentes tratamentos superficiais [Arai e Harper, 1991, e adaptado de Chicco et al., 1999; Child et al., 1984; Sinha, 1991; Sricharoenchai et al., 1998]. 


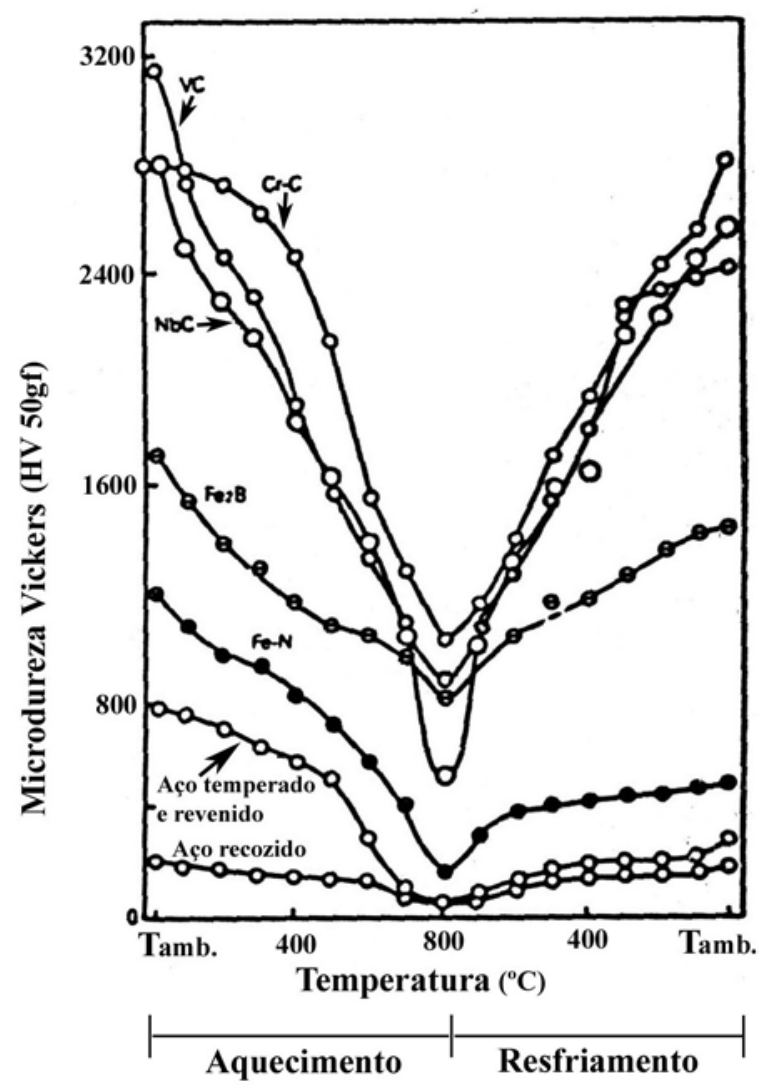

Figura 2.2 - Variação de durezas de diferentes tipos de camadas em ciclos de aquecimentos e resfriamentos [Adaptado de Arai, 1981].

\subsection{Tratamentos termo-reativos de deposição e difusão (TRD)}

O tratamento termo-reativo de deposição e difusão (TRD) é um processo pelo qual um elemento formador de carboneto ou de nitreto é depositado na superfície de um substrato contendo carbono e/ou nitrogênio, para a produção de camadas de carboneto ou carbonitreto do elemento dissolvido (Arai e Harper, 1991; Chicco et al., 1999). As características dessas camadas são elevadas dureza e resistência ao desgaste, baixo coeficiente de atrito, boa resistência à oxidação e a corrosão, além de uma ligação metalúrgica com o substrato, tornando o processo bastante efetivo para a obtenção de um produto com excelentes propriedades tribológicas (Arai e Harper, 1991; Plumb, 1985). Outra grande vantagem é que a elevada dureza superficial não afeta a tenacidade da peça (Plumb, 1985), que é governada pela tenacidade do substrato (Arai et al., 1987). A espessura da camada 
geralmente situa-se na faixa de 5 a $15 \mu \mathrm{m}$, dependendo de fatores como parâmetros do tratamento e quantidade de carbono no substrato (Plumb, 1985; Sricharoenchai et al., 1998). Os tratamentos TRD são realizados em temperaturas elevadas, geralmente entre 850 e $1050^{\circ} \mathrm{C}$, com tempos de tratamentos que variam de $0,5 \mathrm{a}$ 10h (Arai e Harper, 1991).

As camadas produzidas por meio do tratamento TRD encontram as mesmas aplicações industriais dos revestimentos de TiC, TiN e TiCN obtidos pelos métodos CVD e PVD, com a vantagem de ser um processo mais simples e ter um custo menor. Enquanto nos processos PVD e CVD utilizam-se câmaras de vácuo, atmosferas controladas e o manuseio de gases (Bunshah, 1992), o tratamento TRD pode ser realizado em fornos comuns de tratamentos térmicos, utilizando cadinhos ou caixas metálicas, em atmosfera ambiente (Arai et al., 1987; Arai, 1992). Uma comparação entre os três processos é realizada na tabela 2.1 .

Tabela 2.1 - Características dos processos CVD, PVD e TRD.

\begin{tabular}{||l|c|c|c||}
\hline & CVD & PVD & TRD \\
\hline Revestimento & TiN, TiCN, TiC & TiN & VC \\
\hline Espessura $(\mu \mathrm{m})$ & $5-10$ & $2-5$ & $2-15$ \\
\hline $\begin{array}{l}\text { Temperatura de } \\
\text { tratamento }\left({ }^{\circ} \mathrm{C}\right)\end{array}$ & $950-1050$ & $180-550$ & $850-1050$ \\
\hline $\begin{array}{l}\text { Tratamento térmico } \\
\text { da peça }\end{array}$ & $\begin{array}{c}\text { Após } \\
\text { revestimento }\end{array}$ & $\begin{array}{c}\text { Antes do } \\
\text { revestimento }\end{array}$ & $\begin{array}{c}\text { Após } \\
\text { revestimento }\end{array}$ \\
\hline $\begin{array}{l}\text { Problema de } \\
\text { distorção }\end{array}$ & Severo & Leve & Severo \\
\hline Adesão à camada & Alta & Baixa & Alta \\
\hline Polimento & $\begin{array}{l}\text { Usualmente } \\
\text { necessário }\end{array}$ & $\begin{array}{c}\text { Necessário ou } \\
\text { não }\end{array}$ & $\begin{array}{c}\text { Usualmente } \\
\text { necessário }\end{array}$ \\
\hline
\end{tabular}

[Adaptado de Arai, 1992].

As aplicações mais freqüentes das camadas de carbonetos são em matrizes usadas na estampagem de metais, nas operações de forjamento a quente e a frio e na trefilação de arames e tubos, em moldes de fundição sob pressão de alumínio, 
em ferramentas de corte para metais e não-metais e em peças de precisão da indústria têxtil (Plumb, 1985).

As camadas de VC e de NbC são as que apresentam melhores desempenhos nas solicitações de desgaste. No caso de aplicações onde a resistência à oxidação a temperaturas elevadas é o principal requisito, uma camada de $\mathrm{Cr}_{7} \mathrm{C}_{3}$ é mais adequada (Plumb, 1985; Arai et al., 1987). Wang (1997) mostrou que uma camada de VC exibiu uma resistência ao desgaste entre 9 e 30 vezes superior a de um aço temperado, o que foi atribuído à elevada dureza da camada, a qual estava bem ligada e compatível com o substrato. Diebel et al. (2001) mostraram que $\mathrm{VC}$ foi mais resistente ao desgaste do que revestimentos de $\mathrm{TiN}$ e TiCN, utilizando o ensaio de desgaste do tipo pino sobre disco.

O tratamento TRD de um aço pode ser projetado para ser realizado na sua temperatura de austenitização, de forma que a têmpera possa ser realizada diretamente do banho, por meio de resfriamento em água, óleo, sal ou ar, dependendo da dureza requerida do núcleo, do tamanho da peça e da temperabilidade do material tratado (Arai e Harper, 1991). O revenido pode ser realizado ao ar, sob vácuo ou em gás protetor (Arai, 1979).

Outra grande vantagem do processo TRD é que ferramentas podem ser reprocessadas para reconstituição da camada. Arai e Harper (1991) reportaram que algumas ferramentas foram re-tratadas até oito vezes.

O processo TRD pode ocorrer em banho de sal (Arai e Harper, 1991; Plumb, 1985; Arai et al., 1988), meio sólido (Sen, 2004; Topuz e Toplu, 1999) ou leito fluidizado (King et al., 2004; Chen et al., 1998).

Os tratamentos TRD realizados em banhos de bórax, com adição de elementos formadores de carboneto (EFC's), são conhecidos como o processo TD (“Toyota Diffusion”). Nesse processo, substratos contendo carbono são imersos no banho de bórax contendo $\mathrm{V}, \mathrm{Nb}$ ou $\mathrm{Cr}$, para a obtenção de camadas de $\mathrm{VC}, \mathrm{NbC}$, 
$\mathrm{Cr}_{7} \mathrm{C}_{3}$ e $\mathrm{Cr}_{23} \mathrm{C}_{6}$ (Arai e Harper, 1991). Aços submetidos a esse tratamento devem apresentar um teor de carbono superior a $0,3 \%$ (em massa). A camada se forma pela combinação química do carbono presente no substrato com o elemento formador de carboneto (EFC) dissolvido no banho, conforme esquematizado na figura 2.3. A composição química da camada é praticamente independente da composição química do substrato (Arai, 1979).

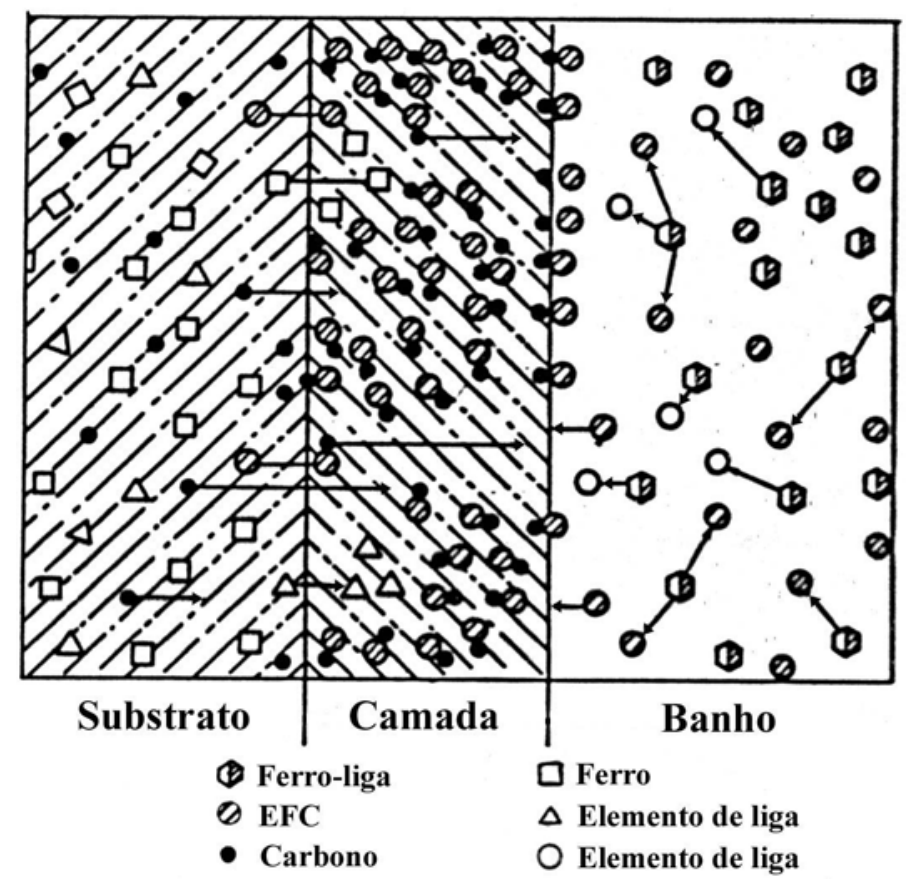

Figura 2.3 - Esquema do mecanismo de formação da camada de carboneto no processo TD [Adaptado de Tokyo Heat Treating Co.[s.n.t.]].

A obtenção de camadas nas superfícies de peças tratadas em banhos de bórax depende dos aditivos presentes nos banhos. O tipo da camada formada pode ser explicado considerando-se as energias livres de formação de carboneto e de óxido relativas ao elemento dissolvido. A figura 2.4 ilustra graficamente a relação entre os tipos de camadas formadas em um aço de alto carbono, em banho de bórax, e as energias livres de formação de óxidos e de carbonetos do elemento adicionado (Arai et al., 1987). Elementos como V, Nb e Cr são bons aditivos para 
tratamento em banhos de bórax, uma vez que apresentam energias livres de formação de carboneto relativamente baixas e energias livres de formação de óxido superiores a do $\mathrm{B}_{2} \mathrm{O}_{3}$ (Arai et al., 1987; Child et al., 1984).

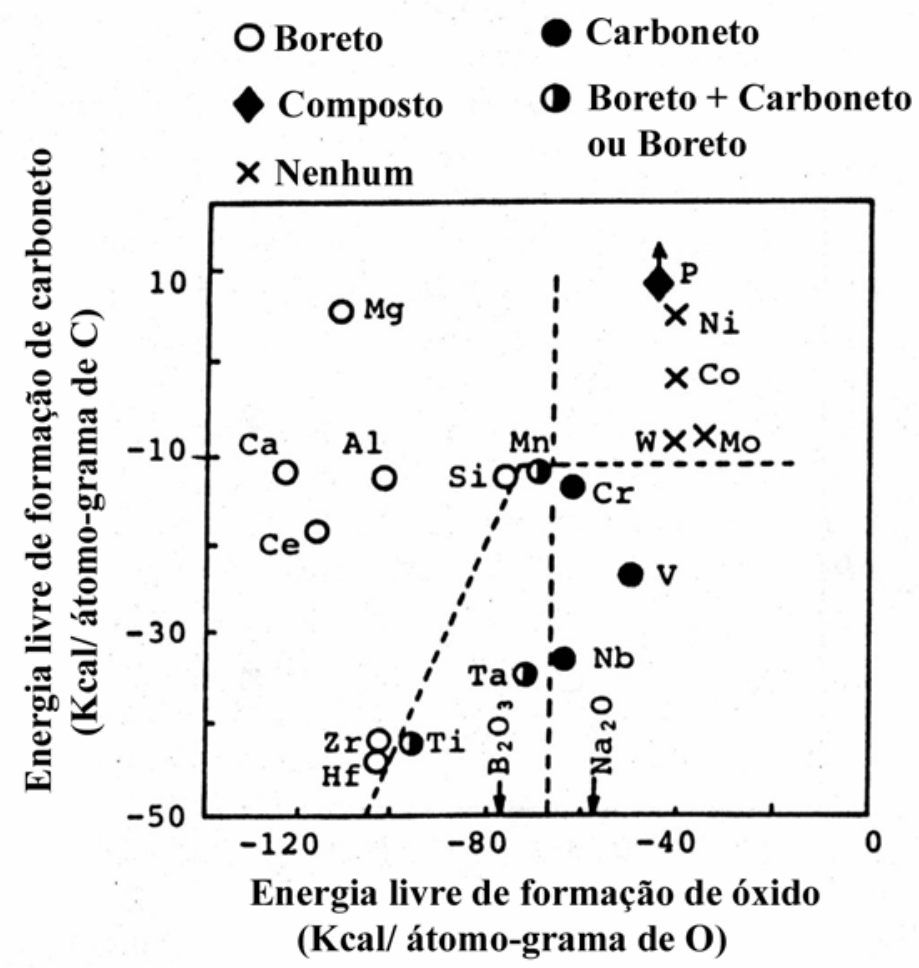

Figura 2.4 - Relação entre as energias livres de formação de carbonetos e de óxidos de elementos adicionados a um banho de bórax e os tipos de camadas produzidas em um aço alto carbono, a $1000^{\circ} \mathrm{C}$ [Adaptado de Arai et al., 1987].

Se o elemento dissolvido possuir energias livres de formação de carboneto e de óxido relativamente baixas, pode ocorrer a reação de redução do $\mathrm{B}_{2} \mathrm{O}_{3}$, com uma conseqüente liberação de átomos de boro, possibilitando assim, a formação de boretos e carbonetos (Arai et al., 1987). Ti, Ta e Mn pertencem a esta categoria, conforme mostrado na figura 2.4. Caso o elemento adicionado apresente elevadas energias livres de formação de óxido e de carboneto, não se obtêm camadas de carbonetos nem de boretos (Arai et al., 1987). 
Os EFC's são introduzidos no banho em forma de ferro-liga ou de óxido, sendo necessário também a adição de um agente redutor como $\mathrm{B}_{4} \mathrm{C}$ ou alumínio (Arai e Harper, 1991; Arai e Moriyama, 1994). Child et al. (1984) observaram que banhos compostos de $\mathrm{Na}_{2} \mathrm{~B}_{4} \mathrm{O}_{7}-\mathrm{V}_{2} \mathrm{O}_{5}$, sem adição de um agente redutor, não se mostraram ativos para produzir uma camada de VC.

Mesmo quando se usa ferro-liga de um EFC como aditivo, a utilização de um agente redutor pode ser necessária. Isso ocorre porque os ferros-ligas não se dissolvem no bórax fundido em forma de elementos metálicos, sendo inicialmente oxidados. Essa oxidação pode acontecer na interface banho/ar, principalmente quando o banho é agitado (Child et al.,1984). Segundo Khoee et al. (1994), quando pós de $\mathrm{Fe}-\mathrm{V}$ ou Fe-Nb são adicionados ao bórax fundido, ocorre primeiro a formação de óxidos de vanádio e de nióbio. De acordo com Child et al., (1984), pode se formar os óxidos $\mathrm{Nb}_{2} \mathrm{O}_{5}$ e $\mathrm{V}_{2} \mathrm{O}_{5}$.

Sricharoenchai et al. (1998) estudaram o efeito da adição de alumínio em banhos de bórax com adição de $\mathrm{Fe}-\mathrm{Nb}$, à atmosfera ambiente e a uma temperatura de tratamento de $1000^{\circ} \mathrm{C}$. O teor de alumínio variou de 0 a $10 \%$ (em peso), enquanto as quantidades de Fe-Nb investigadas situaram-se na faixa de 2 a $32 \%$. Sem adição de alumínio, não se formou camada. Para o banho contendo $10 \% \mathrm{Al}$ ocorreu a formação de $\mathrm{NbC}, \mathrm{NbB}_{2}, \mathrm{FeB}$ e $\mathrm{Fe}_{2} \mathrm{~B}$. Neste caso, o alumínio provavelmente não reduziu apenas o óxido de nióbio $\left(\mathrm{Nb}_{2} \mathrm{O}_{5}\right)$, mas também o $\mathrm{B}_{2} \mathrm{O}_{3}$. Verificou-se que o teor de alumínio de $3 \%$ foi o mais adequado, enquanto o de $\mathrm{Fe}-$ $\mathrm{Nb}$ foi $16 \%$. O alumínio pode reduzir os óxidos mais estáveis $\mathrm{V}_{2} \mathrm{O}_{5}$ e $\mathrm{Nb}_{2} \mathrm{O}_{5}$ para gerar os óxidos menos estáveis $\mathrm{V}_{2} \mathrm{O}_{3}$ e $\mathrm{Nb}_{2} \mathrm{O}_{3}$ ou para liberar átomos do elemento metálico. Por meio de análises químicas quantitativas realizadas em banhos de bórax que foram ativos para se produzir uma camada de VC, Child et al. (1984) constataram que o vanádio estava na forma $\mathrm{V}_{2} \mathrm{O}_{3}$ e não mais na forma que foi adicionado $\left(\mathrm{V}_{2} \mathrm{O}_{5}\right)$. 
Khoee et al. (1994) observaram que a adição de Fe-V ao bórax fundido diminuiu a fluidez do banho, o que implicou em dificuldade de limpeza da peça tratada. Esse problema foi contornado com a adição de ácido bórico, que aumenta a fluidez do banho. Uma composição de banho com 10\%Fe-V e 5\% de ácido bórico foi usada com sucesso. No caso do Fe-Nb, observou-se que a fluidez do banho praticamente não foi afetada pela introdução do ferro-liga, mesmo em quantidades elevadas, de forma que a adição de até $20 \%$ Fe-Nb ao banho foi possível.

As espessuras das camadas de carbonetos são afetadas pela temperatura do banho, tempo de imersão e composição do substrato, particularmente em termos do teor de carbono. Com o aumento da temperatura do banho, tem-se um aumento na taxa de difusão do carbono (Arai e Harper, 1991). A temperatura do banho e o tempo de imersão afetam a espessura da camada como mostrado na figura 2.5 .

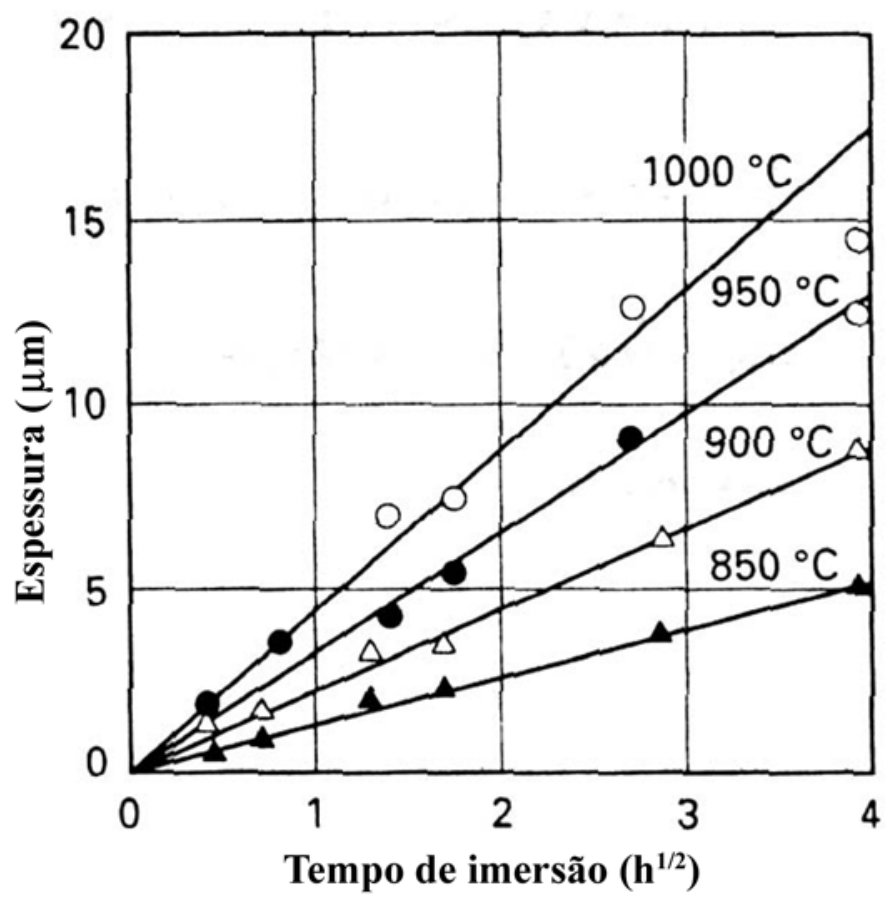

Figura 2.5 - Espessuras de camadas de VC formadas no aço W1 tratado em um banho de bórax contendo $20 \% \mathrm{Fe}-\mathrm{V}$, em diversas temperaturas [Adaptado de Arai e Harper, 1991]. 
Segundo Arai e Harper (1991) a relação entre o tempo de imersão e a espessura da camada obtida é dada pela Eq. (2.1):

$$
e^{2}=k \cdot t
$$

onde,

t: tempo (s)

$\mathrm{k}$ : constante da taxa de crescimento da camada $\left(\mathrm{cm}^{2} / \mathrm{s}\right)$, em função da temperatura

e: espessura da camada $(\mathrm{cm})$

A espessura da camada é independente da composição do banho, desde que a quantidade de CFE adicionado seja suficiente, o que corresponde a teores de ferro-vanádio, ferro-nióbio, ferro-cromo ou cromo puro superiores a $10 \%$. Geralmente, não existe diferença entre as espessuras das camadas de $\mathrm{VC}, \mathrm{NbC}$, $\mathrm{Cr}_{7} \mathrm{C}_{3}$ ou $\mathrm{Cr}_{23} \mathrm{C}_{6}$ (Arai e Harper, 1991).

As camadas obtidas pelo processo TRD podem também ser constituídas de nitretos ou de carbonitretos, dependendo da composição química do substrato (Arai e Harper, 1991; King et al., 2004). Em tratamentos realizados em amostras previamente nitretadas ou carbonitretadas, realizados em banho de bórax contendo vanádio, foram obtidas camadas de nitretos e de carbonitretos de vanádio (Chicco et al., 1999).

Camadas de carbonetos complexos são formadas em banhos contendo dois ou três diferentes tipos de pós metálicos, para se obter uma combinação vantajosa de propriedades (Arai et al., 1987). De acordo com Holleck (1986), a microdureza Vickers do carboneto misto $(\mathrm{V}, \mathrm{Nb}) \mathrm{C}$ pode ser maior do que a dureza dos carbonetos simples $\mathrm{VC}$ ou $\mathrm{NbC}$. 
Camadas de carbonetos podem também ser produzidas por meio de tratamentos TRD realizados a temperaturas relativamente baixas, usando para tanto, outras composições de banhos. Arai et al. (1988) trataram amostras de aços em banhos compostos de cloretos $\left(\mathrm{NaCl}\right.$ e $\left.\mathrm{CaCl}_{2}\right)$ e $\mathrm{Fe}-\mathrm{V}$, na faixa de $550-700^{\circ} \mathrm{C}$. Nesse nível de temperatura, a taxa de difusão do carbono é muito baixa, requerendo tempos de tratamentos longos para formar uma camada com espessura suficiente para aplicações práticas. Uma espessura de camada maior foi conseguida mediante a utilização de tratamentos duplex, consistindo de nitretação, em banho de sal ou iônica, seguida do tratamento em banho de cloreto contendo o ferro-liga (Arai et al., 1988).

\subsection{Tratamento de Boretação}

A boretação é um tratamento superficial onde se obtém camadas de durezas elevadas, constituídas de boretos de elementos do substrato. Durante o tratamento, átomos de boro difundem para o interior do substrato e reagem com o metal base, formando a camada boretada. Esse processo pode ser empregado em uma grande variedade de materiais, ferrosos e não-ferrosos, sendo utilizado para produzir camadas com dureza superficial elevada, alta resistência ao desgaste e baixo coeficiente de atrito. A combinação de elevada dureza com baixo coeficiente de atrito contribui para o combate aos principais mecanismos de desgaste (Sinha, 1991). A camada boretada apresenta também uma boa resistência à oxidação a temperaturas elevadas, de até $900^{\circ} \mathrm{C}$ (Matiašovský et al., 1988).

A forte ligação covalente da maioria dos boretos é a responsável por seus altos valores de ponto de fusão, módulo de elasticidade e dureza (Sen et al., 2001). As camadas boretadas apresentam valores de durezas geralmente na faixa de 1400 a 1800HV (Sen et al., 2005-a; Ozbek e Bindal, 2002). Suas espessuras podem variar de 21 a $380 \mu \mathrm{m}$, dependendo dos parâmetros do tratamento como 
tempo e temperatura, e da presença de elementos de liga no substrato (Ozbek e Bindal, 2002; Özbek et al., 2002; Sen et al., 2005-b). Os tratamentos geralmente são realizados entre 700 e $1000^{\circ} \mathrm{C}$ (Sen et al., 2001; Genel et al., 2003).

O tratamento de boretação pode ocorrer em meio sólido, líquido, gasoso, leito fluidizado ou por plasma (Sinha, 1991; Sen et al., 2001; Özbek et al., 2002; Sen e Sen, 2003; Cabeo et al., 1999). A boretação em meio líquido foi o método usado no presente trabalho.

No processo de boretação termoquímica em banho de sal, utiliza-se um meio boretante contendo uma fonte de boro (por exemplo, $\mathrm{Na}_{2} \mathrm{~B}_{4} \mathrm{O}_{7}, \mathrm{KBF}_{4}$ ou $\mathrm{K}_{2} \mathrm{~B}_{4} \mathrm{O}_{7}$ ) e um agente redutor (principalmente $\mathrm{B}_{4} \mathrm{C}$, SiC, Fe-Al ou $\mathrm{Al}$ ). A redução termoquímica que ocorre na mistura boretante libera boro elementar, que difunde para o interior do substrato (Matiašovský et al., 1988). Os átomos de boro reagem com o metal base, formando uma camada de boretos (Sinha, 1991; Genel et al., 2003; Ozbek e Bindal, 2002).

Dependendo da natureza do agente redutor, a mistura boretante pode apresentar um potencial de boretação maior, que se verifica na obtenção de camadas mais espessas e de fases ricas em boro. Em tratamentos realizados em um aço carbono, a $900^{\circ} \mathrm{C}$, a ação redutora do $\mathrm{B}_{4} \mathrm{C}$ foi maior do que a do $\mathrm{SiC}$ (Matiašovský et al., 1988). Por sua vez, de acordo com Sinha (1991), o efeito redutor do alumínio é mais efetivo do que o do $\mathrm{B}_{4} \mathrm{C}$.

Devido ao seu tamanho relativamente pequeno e a sua alta mobilidade, os átomos de boro podem difundir facilmente em ligas ferrosas e formar os compostos FeB e $\mathrm{Fe}_{2} \mathrm{~B}$ (Genel et al., 2003; Sen et al., 2001). O processo de formação da camada de boreto é então controlado pela difusão do boro através da rede do substrato. A taxa de crescimento e a composição química da camada são determinadas pela concentração de boro no banho (potencial de boretação), temperatura de tratamento e composição química do substrato. Temperatura e 
tempo de tratamentos mais elevados, assim como um maior potencial de boretação da mistura, produzem camadas com espessuras maiores (Matiašovský et al., 1988; Ozbek e Bindal, 2002).

As fases que se formam dependem da composição química do substrato. Nos aços, as camadas são constituídas predominantemente de $\mathrm{Fe}_{2} \mathrm{~B}$ e $\mathrm{FeB}$, assim como de boretos dos elementos de liga, tais como Cr, V, Mo e Ni (Sinha, 1991; Sen e Sen, 2003; Özbek et al., 2002).

A camada boretada pode ser formada por uma fase única $\mathrm{Fe}_{2} \mathrm{~B}$ ou por uma dupla fase $\mathrm{FeB}+\mathrm{Fe}_{2} \mathrm{~B}$ (Martini et al., 2004-b). Em aplicações tribológicas, uma camada boretada constituída pela fase única $\mathrm{Fe}_{2} \mathrm{~B}$ geralmente é mais desejável, pois a fase $\mathrm{FeB}$, rica em boro, é mais frágil (Sen e Sen, 2003). A tenacidade à fratura da fase $\mathrm{Fe}_{2} \mathrm{~B}$ é aproximadamente quatro vezes superior a da fase $\mathrm{FeB}$ (Ozbek e Bindal, 2002). Outro fator a ser considerado é que as duas fases apresentam comportamentos distintos, com diferenças significativas em seus módulos de elasticidade e coeficientes de expansão térmica, de maneira que a formação de trincas ao longo da interface $\mathrm{FeB} / \mathrm{Fe}_{2} \mathrm{~B}$ é freqüentemente observada (Sinha, 1991; Ozbek e Bindal, 2002; Martini et al., 2004-a). Na tabela 2.2 são apresentadas algumas propriedades das fases $\mathrm{FeB}$ e $\mathrm{Fe}_{2} \mathrm{~B}$.

Tabela 2.2 - Propriedades das fases $\mathrm{Fe}_{2} \mathrm{~B}$ e FeB.

\begin{tabular}{||l|l|l||}
\hline \hline $\begin{array}{l}\text { Teor de boro } \\
\text { (\% em massa) }\end{array}$ & $\mathrm{FeB}$ & $\mathrm{Fe}_{2} \mathrm{~B}$ \\
\hline Estrutura & 16,23 & 8,83 \\
\hline Parâmetro de rede $(\AA)$ & ortorrômbica & $\begin{array}{l}\text { tetragonal de corpo } \\
\text { centrado }\end{array}$ \\
\hline Densidade $\left(\mathrm{g} / \mathrm{cm}^{3}\right)$ & $\begin{array}{l}\mathrm{a}=4,053 \\
\mathrm{~b}=5,495 \\
\mathrm{c}=2,946\end{array}$ & $\begin{array}{l}\mathrm{a}=5,078 \\
\mathrm{c}=4,249\end{array}$ \\
\hline $\begin{array}{l}\text { Coeficiente de expansão térmica, } \\
\text { entre 200 e } 600^{\circ} \mathrm{C}\left(10^{-6}{ }^{\circ} \mathrm{C}^{-1}\right)\end{array}$ & 6,75 & 7,43 \\
\hline Módulo de elasticidade $(\mathrm{GPa})$ & 23 & 7,65 \\
\hline Microdureza $(\mathrm{GPa})$ & 590 & $285-295$ \\
\hline \hline
\end{tabular}

[Adaptado de Sinha, 1991]. 
A formação da fase rica em boro $\mathrm{FeB}$, depende da disponibilidade de boro e da composição química do substrato (Sen e Sen, 2003). A maioria dos elementos de liga presentes em um aço tende a formar uma barreira de difusão, reduzindo a taxa de crescimento da camada (Matiašovský et al., 1988; Sinha, 1991). Com a dificuldade de difusão do boro provocada pela presença de elementos de liga, sua concentração na superfície do substrato aumenta, levando à formação da fase FeB (Ozbek e Bindal, 2002).

A morfologia da camada também é afetada pela composição do substrato. Em aços de baixo carbono e em ferro puro, pode ocorrer a formação de uma camada com uma morfologia dentada na interface camada/substrato, sendo conhecida como do tipo "dente-de-serra" (Sinha, 1991). Teores de carbono e/ou elementos de liga mais elevados tendem a suprimir o desenvolvimento de uma camada com esta morfologia (Sinha, 1991).

O carbono não se dissolve significativamente na camada boretada e durante o processo de boretação é forçado a difundir em direção à matriz, podendo formar sob a camada, o composto misto do tipo $\mathrm{Fe}_{3}(\mathrm{~B}, \mathrm{C})$, chamado de borocementita (Sinha, 1991). Assim como o carbono, o silício é insolúvel na camada de boreto de ferro, e tende a se concentrar na interface da camada com o substrato (Palombarini e Carbucicchio, 1993). O silício é um elemento formador de ferrita e produz, em alguns casos, uma zona ferrítica sob a camada de boreto, com dureza inferior à da matriz, criando o efeito conhecido como "casca de ovo", que é a formação de uma camada ferrítica "mole" entre a camada de boreto e a matriz (Sinha, 1991; Chicco et al., 1998).

O cromo pode modificar consideravelmente a morfologia e a constituição dos boretos de ferro. Quando o teor de cromo aumenta, os efeitos observados são uma diminuição na espessura da camada, a tendência a formação de uma interface plana desta com o substrato e a obtenção de produtos ricos em cromo (Sinha, 
1991). O cromo pode reagir com o boro, formando compostos binários ( $\mathrm{Cr}-\mathrm{B}$ ) e/ou ternários (Fe-Cr-B) (Matiašovský et al., 1988). A substituição do ferro por cromo nos compostos $\mathrm{FeB}$ e $\mathrm{Fe}_{2} \mathrm{~B}$ da camada pode ocorrer, e dessa forma, ter-se os boretos mistos (Fe,Cr)B ou (Fe,Cr) $)_{2} \mathrm{~B}$ (Matiašovský et al., 1988; Chicco et al., 1998). Outros elementos de liga como $\mathrm{Mn}, \mathrm{W}$, Mo e $\mathrm{V}$ também reduzem a espessura da camada $\mathrm{e}$ contribuem para a formação de uma interface camada/substrato plana (Sinha, 1991).

\subsection{Modos de desgaste dos materiais}

Desgaste pode ser definido como um dano a uma superfície sólida, que geralmente envolve a perda de material, ocasionado pelo movimento relativo entre duas superfícies de contato. O desgaste pode ser provocado por uma outra superfície sólida ou por partículas duras, que podem deslizar, rolar ou colidir contra uma superfície sólida (Tylczak, 1992).

Os materiais podem sofrer desgaste por meio de uma variedade de mecanismos, como abrasão, adesão, fadiga, corrosão, oxidação e erosão, os quais são influenciados por fatores como ambiente, temperatura, condições de carregamento e superfícies de contato (Bayer, 1985).

O desgaste abrasivo ocorre devido à ação de partículas ou de protuberâncias duras que se movem ao longo da superfície sólida de um material (Tylczak, 1992). Estas partículas podem remover material por meio de microcortes, microfraturas ou arrancamento de grãos. O próprio material removido da superfície de desgaste pode agir como partículas abrasivas (Stachowiak e Batchelor, 1993).

O desgaste abrasivo pode ser classificado basicamente como desgaste abrasivo a dois corpos e a três corpos, dependendo da maneira como as partículas atuam sobre a superfície de desgaste. O modo de desgaste abrasivo a dois corpos ocorre quando uma aspereza dura da superfície de contato (contra corpo) ou uma 
partícula rigidamente fixada a esta (Fig. 2.6), desliza sobre a superfície de desgaste como uma ferramenta de corte, sendo caracterizado pela presença de sulcos ou ranhuras lineares na direção de deslizamento. No desgaste abrasivo a três corpos a partícula de desgaste está livre para rolar (assim como para deslizar) na região de contato (Fig. 2.7). Neste caso, a superfície de desgaste normalmente apresenta uma topografia aleatória, sem características de direcionalidade (Trezona et al., 1999; Stachowiak e Batchelor, 1993).

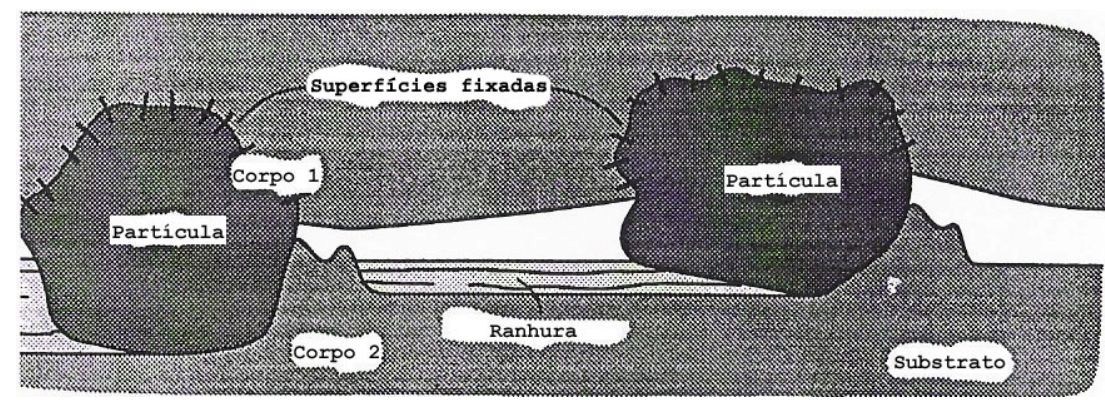

Figura 2.6 - Esquema do modo de desgaste abrasivo a dois corpos [Adaptado de Stachowiak e Batchelor, 1993].

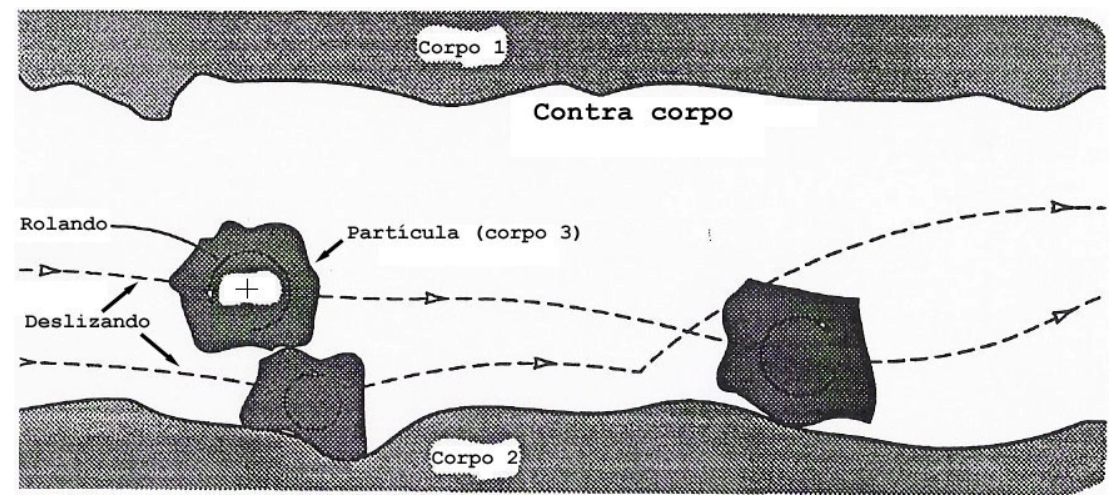

Figura 2.7 - Esquema do modo de desgaste abrasivo a três corpos [Adaptado de Stachowiak e Batchelor, 1993].

O desgaste adesivo é uma forma severa de avaria dos materiais, caracterizado por altas taxas de desgaste e elevada instabilidade do coeficiente de atrito. Superfícies de contato deslizantes podem ser rapidamente destruídas, e em 
alguns casos, o movimento relativo pode até mesmo ser impedido. Os metais apresentam uma forte tendência à adesão quando em contato com um outro corpo sólido (Stachowiak e Batchelor, 1993).

O desgaste adesivo ("scoring", "galling", "seizing") ocorre quando duas superfícies sólidas deslizam uma contra a outra, a uma pressão de contato suficiente para causar deformação plástica local e adesão. Esta forma de desgaste é favorecida por superfícies limpas, condições não oxidantes e similaridade química e estrutural entre o par deslizante (Eyre, 1991). As duas superfícies colam uma na outra, e com um subseqüente movimento, ocorre a ruptura em um dos materiais (Bayer, 1985). Protuberâncias na superfície de contato são deformadas plasticamente e eventualmente "soldadas" como um efeito da pressão local. Com o deslizamento, estas ligações podem ser quebradas, produzindo partículas abrasivas, o que contribui para um desgaste ainda maior (Askeland, 1994).

Em uma grande parte de contatos deslizantes, como mancais, engrenagens, correntes e excêntricos, a causa de falhas rápidas, algumas vezes catastróficas, é o desgaste adesivo. Quando duas superfícies de contato não são devidamente separadas, como por exemplo, por um lubrificante, este modo de desgaste é quase inevitável (Stachowiak e Batchelor, 1993).

A formação de filmes na superfície de desgaste é uma característica do desgaste adesivo, onde material é transferido de uma superfície para outra (Fig. 2.8), podendo ser subseqüentemente liberado como partículas de desgaste. Isto distingue o desgaste adesivo da maioria dos outros mecanismos de desgaste (Stachowiak e Batchelor, 1993).

As propriedades do material são muito importantes no sentido de reduzir o desgaste adesivo. Normalmente, se as superfícies de contato têm durezas elevadas, a taxa de desgaste é baixa. Por exemplo, no caso dos materiais 
cerâmicos, devido a sua excepcional dureza e baixo coeficiente de atrito, espera-se uma boa resistência a este modo de desgaste (Askeland, 1994).

Os metais usualmente têm uma coesão menor do que os materiais cerâmicos, de forma que, num par tribológico metal-cerâmica, quando os pontos de contato se rompem, fragmentos de metal freqüentemente ficam aderidos ao material cerâmico. Maior adesão tende a ocorrer entre metais do mesmo tipo, como por exemplo ferro com ferro (Stachowiak e Batchelor, 1993).

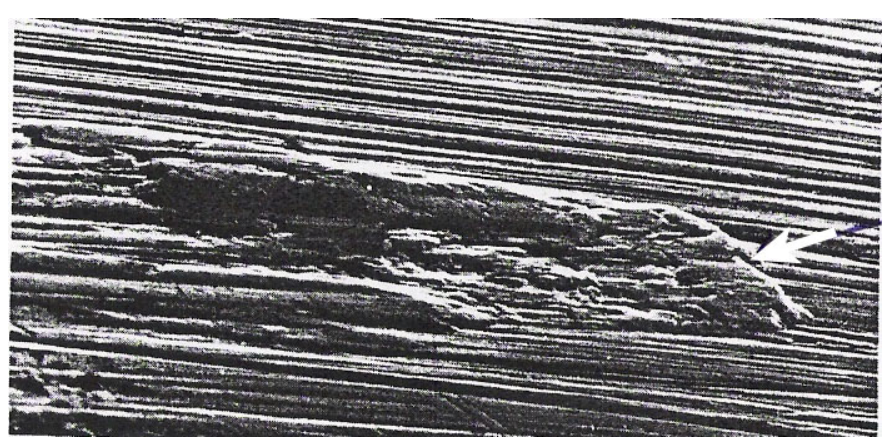

Figura 2.8 - Filme aderido à superfície de desgaste caracterizando o modo de desgaste adesivo [Adaptado de Stachowiak e Batchelor, 1993].

Desgaste por fadiga ocorre quando uma superfície é submetida a tensões cíclicas locais, que levam à formação de trincas (Bayer, 1985). A superfície de desgaste apresenta um elevado grau de deformação plástica. Ocorre a iniciação e o crescimento de trincas, seguido de fratura e geração de partículas de desgaste. 0 modo de desgaste por fadiga pode ocorrer quando duas superfícies deslizam entre si ou quando uma rola sobre a outra (Stachowiak e Batchelor, 1993).

O desgaste corrosivo está relacionado a qualquer forma de desgaste causada por um processo corrosivo, enquanto o desgaste oxidativo é aquele causado pela ação do oxigênio da atmosfera. A causa fundamental desses tipos de desgaste é uma reação química entre a superfície de desgaste e um meio corrosivo, que pode ser um reagente químico, um lubrificante reativo ou o próprio 
ar. A reação química que ocorre na superfície de um material, enquanto este é submetido a uma situação de desgaste, pode promover a formação de um filme durável. Assim, tem-se um efeito benéfico, com uma redução do coeficiente de atrito entre as superfícies de contato e uma melhora na resistência ao desgaste. Entretanto, a formação de um filme durável é muito pouco observada na prática, de maneira que a forma mais comum de desgaste corrosivo ocorre com a formação e subseqüente destruição de um filme fino de curto tempo de vida, na superfície de desgaste. Este filme geralmente consiste de óxidos ou compostos iônicos frágeis, que podem ser quebrados, gerando partículas de desgaste de alta dureza (Stachowiak e Batchelor, 1993).

\subsection{Ensaio de desgaste micro-abrasivo}

O ensaio de desgaste micro-abrasivo ("micro-abrasive" ou "ball cratering") é um método relativamente novo de avaliação da resistência ao desgaste de materiais, que despertou o interesse de muitos pesquisadores e está sendo analisado com o objetivo de se chegar à sua normalização. Neste sentido, grupos de pesquisadores, na Europa e nos EUA, estão realizando ensaios em diferentes laboratórios para estudar a sua reprodutibilidade (Gee et al., 2003).

O ensaio consiste na rotação de uma esfera, sob pressão e na presença de um abrasivo, contra uma superfície plana da amostra, onde se obtém uma calota, chamada de calota ou cratera de desgaste ("wear crater"). O volume da calota de desgaste é calculado e definido como volume de desgaste (Rutherford e Hutchings, 1996; Gee et al., 2003).

Duas variantes do teste, conhecidas como ensaio com a esfera "livre" e ensaio com a esfera "fixada" (Gee et al., 2003), são mostradas esquematicamente nas figuras 2.9 e 2.10, respectivamente. No primeiro caso, a esfera é apoiada sobre a amostra e um eixo motor pela ação de seu próprio peso (figura 2.9). O eixo 
gira e transmite rotação a esfera, ocasionando seu deslizamento sobre a superfície da amostra. Esse tipo do ensaio é também conhecido como "Calotest" ou "Calowear" (Stachowiak e Stachowiak, 2004; Staia et al., 1998; Badisch e Mitterer, 2003; Jones, 2005). A carga aplicada é determinada pelo peso da esfera, pela posição lateral do eixo e pela inclinação da amostra, sendo limitada a pequenos valores (Gee et al., 2003).

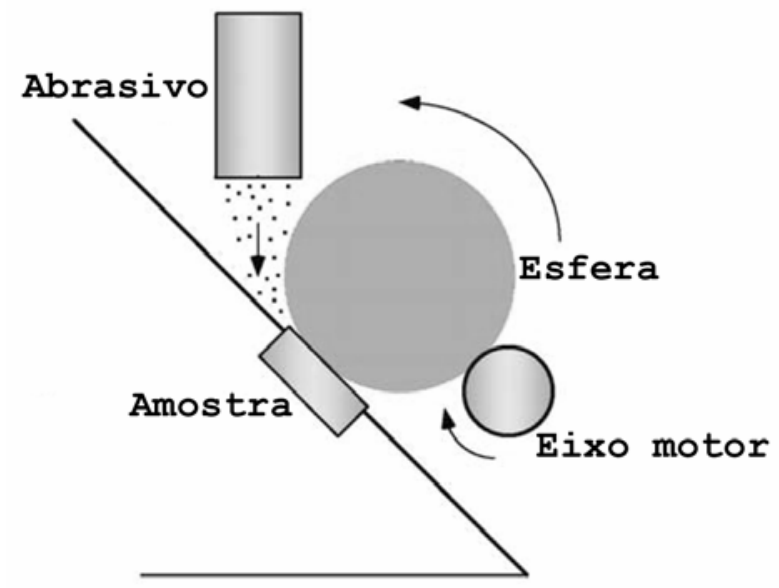

Figura 2.9 - Diagrama esquemático do ensaio de desgaste micro-abrasivo com a esfera "livre" [Adaptado de Stachowiak e Stachowiak, 2004].

No ensaio de desgaste micro-abrasivo com a esfera "fixada", esta é rigidamente presa entre dois eixos co-axiais, conforme mostrado na figura 2.10 , e gira exatamente na mesma rotação dos eixos. Neste caso, pode-se aplicar uma grande variedade de cargas $\left(F_{N}\right)$ na região de contato (Fig. 10b), bastando para isso variar o peso suspenso. Neste ensaio não existe a possibilidade de deslizamento da esfera, como pode ocorrer no tipo esfera livre (Gee et al., 2003). 

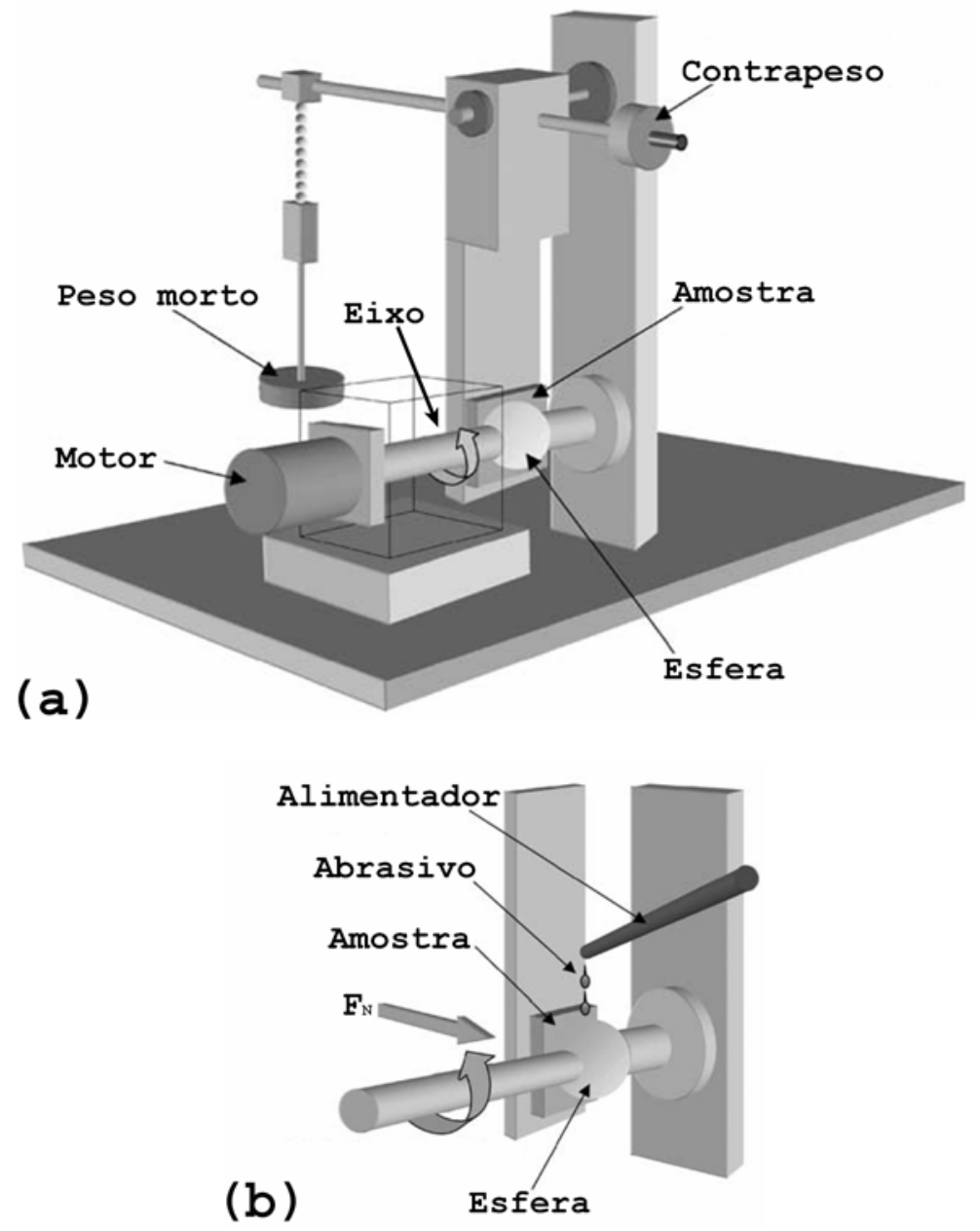

Figura 2.10 - (a) Diagrama esquemático do ensaio de desgaste micro-abrasivo com a esfera "fixada"; (b) Mesmo ensaio, destacando a esfera, a amostra e o abrasivo [Adaptado de Adachi e Hutchings, 2003].

O ensaio de desgaste micro-abrasivo apresenta muitas vantagens em comparação com outros testes de desgaste, tais como facilidade de operação, preparação muito simples das amostras e versatilidade. O par amostra/esfera pode ser facilmente trocado, o equipamento é relativamente barato e as amostras podem ser pequenas (Gee et al., 2003; Rutherford e Hutchings, 1996; Staia et al., 1998). O ensaio pode ser usado também para medir espessuras de camadas (Staia et al., 1998; Allsopp e Hutchings, 2001). O método pode ser adaptado para ensaiar amostras em temperaturas elevadas, como por exemplo, a $350^{\circ} \mathrm{C}$ (Allsopp e Hutchings, 2001). 
A pequena área da amostra requerida para o teste, juntamente com a pequena profundidade de penetração, torna o ensaio adequado ao estudo de pequenas amostras e de componentes tratados superficialmente (Rutherford e Hutchings, 1996). Por exemplo, o método permite avaliar a resistência ao desgaste de camadas de $\mathrm{TiN},(\mathrm{Ti}, \mathrm{Al}) \mathrm{N}$ e $\mathrm{Ti}(\mathrm{C}, \mathrm{N})$ obtidas por PVD, com espessuras entre $1 \mathrm{e}$ $5 \mu \mathrm{m}$, ou de fitas amorfas, com dimensões de $2 \mathrm{~mm} \times 5 \mathrm{~mm} \times 40 \mu \mathrm{m}$ (Rutherford e Hutchings, 1997).

Utilizando este ensaio, Allsopp e Hutchings (2001) investigaram a resistência ao desgaste de revestimentos de TiN, TiCN e AITiN obtidos por PVD em um aço-ferramenta, com espessuras na faixa de 1,5 a $5,1 \mu \mathrm{m}$. Rutherford e Hutchings (1996) usaram o método para medir as resistências ao desgaste de camadas de TiN, TiCN e TiAIN obtidas por PDV em aços ferramentas. Batista et al. (2003) estudaram o comportamento ao desgaste de revestimentos de TiN obtidos por PVD no aço AISI H13. Martini et al. (2004-a) avaliaram a resistência ao desgaste de camadas de boretos de ferro.

Inicialmente desenvolvido para o estudo de revestimentos duros, o teste de desgaste micro-abrasivo é usado também para avaliar a resistência ao desgaste de materiais do substrato, assim como de materiais "moles". Como exemplos de materiais analisados incluem-se aços ferramentas (Trezona et al., 1999; Jones, 2005), aços carbono (Staia et al., 1998), ferro-fundido (Stachowiak e Stachowiak, 2004), carboneto duro sinterizado (Chen et al., 2005), alumínio comercialmente puro e poli-metacrilato de metila-PMMA (Trezona e Hutchings, 1999).

As esferas comumente usadas são de aço para rolamento (AISI 52100) com 25,4mm de diâmetro (Bose e Wood, 2005, Trezona et al., 1999, Batista et al., 2002), sendo também utilizadas esferas do aço inoxidável 440C (Shipway, 1999). Esferas de polipropileno foram usadas por Adachi e Hutchings (2005) para ensaiar amostras de PMMA. 
O modo de desgaste micro-abrasivo pode ocorrer a dois corpos ou a três corpos, dependendo do movimento das partículas abrasivas na região de contato entre a esfera e a superfície da amostra (Bose e Wood, 2005).

Stack e Mathew (2003) estudaram o comportamento ao desgaste de açocarbono, alumínio e cobre, utilizando uma suspensão de SiC como abrasivo, e verificaram que o desgaste abrasivo a três corpos puro raramente existe, e que este é quase sempre acompanhado pela presença de ranhuras, provocadas por partículas agarradas ao contra corpo, que são arrastadas sobre a superfície desgaste.

Adachi e Hutchings (2003) observaram uma mudança no modo de desgaste, de abrasão a três corpos para abrasão a dois corpos, com o aumento da carga e a diminuição da concentração de abrasivo.

Trezona et al. (1999) avaliaram os mecanismos de desgaste em função da carga aplicada e da concentração do abrasivo, utilizando três tipos de abrasivos: $\mathrm{SiC}, \mathrm{Al}_{2} \mathrm{O}_{3}$ e diamante. $\mathrm{O}$ desgaste abrasivo a dois corpos foi dominante para altas cargas e/ou baixas concentrações de abrasivos, para os três tipos de abrasivos utilizados. Esse modo de desgaste ocorre quando as partículas são incrustadas na superfície da esfera e agem como uma ponta cortante, produzindo uma série de riscos paralelos na superfície da amostra, conforme mostra-se na figura 2.11. Em condições de baixas cargas e/ou elevadas concentrações do abrasivo, o modo de desgaste a três corpos foi dominante. Neste caso, as partículas ficaram livres para rolar na área de contato, produzindo uma superfície de desgaste sem evidência de direcionalidade, como mostrado na figura 2.12 . 


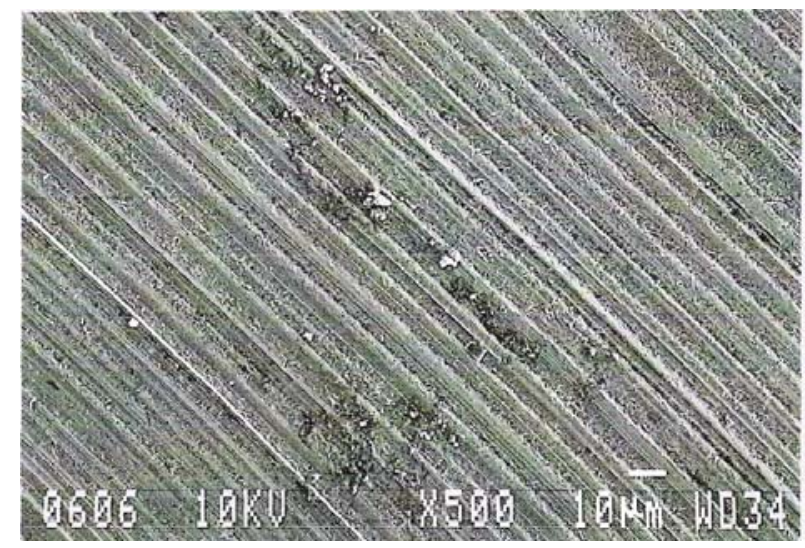

Figura 2.11 - Superfície de desgaste típica para o modo de abrasão a dois corpos. Observa-se a presença de riscos paralelos [Trezona et al., 1999].

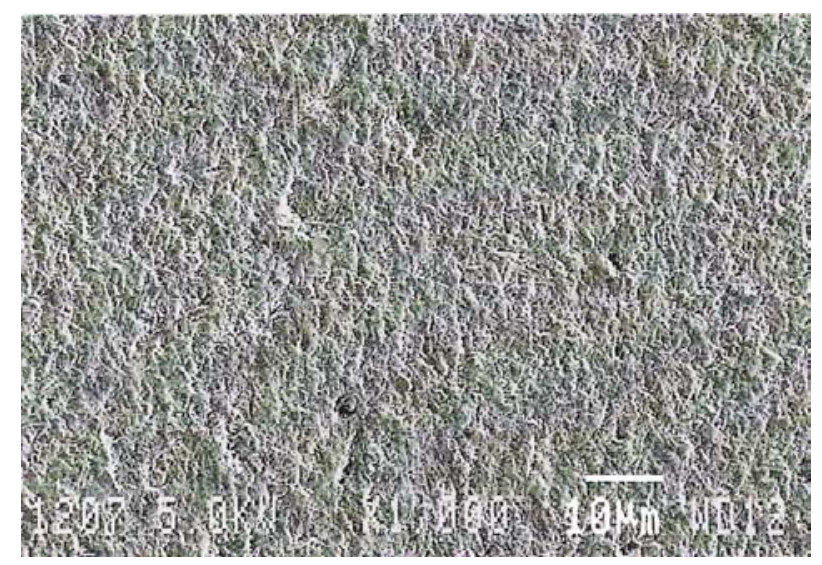

Figura 2.12 - Superfície de desgaste típica do modo de abrasão a três corpos [Trezona et al., 1999].

O modo de desgaste pode ser influenciado também pelo material da esfera e da amostra (Adachi e Hutchings, 2003). No caso de esfera mole, pode se ter uma maior quantidade de partículas aderidas à sua superfície, o que promove o desgaste por riscamento (Gee et al., 2003).

A superfície de desgaste pode ainda apresentar uma característica mista, com abrasão a dois e a três corpos (Adachi e Hutchings, 2003; Trezona et al., 1999).

No presente trabalho, utilizou-se uma máquina de maior porte, com a esfera fixada, para a realização de ensaios de desgaste em micro-escala, com carga 
elevada e sem o uso de abrasivos, simulando condições de desgaste do tipo adesivo-abrasivo.

Apresenta-se, a seguir, o procedimento experimental utilizado, indicando-se os materiais usados e descrevendo-se a metodologia dos tratamentos realizados e as análises empregadas na caracterização das amostras estudadas. 


\section{PROCEDIMENTO EXPERIMENTAL}

\subsection{Materiais}

Os materiais usados como substratos para os tratamentos termo-reativos foram os aços ferramentas AISI H13 e D2.

Os componentes dos banhos foram bórax (borato de sódio P.A.: $\mathrm{Na}_{2} \mathrm{~B}_{4} \mathrm{O}_{7} .10 \mathrm{H}_{2} \mathrm{O}$ ), ferro-nióbio (63\% Nb, em peso), ferro-vanádio ( $46 \% \mathrm{~V}$, em peso), ferro-titânio (34\%Ti, em peso) e alumínio, os quais são mostrados na figura 3.1 .

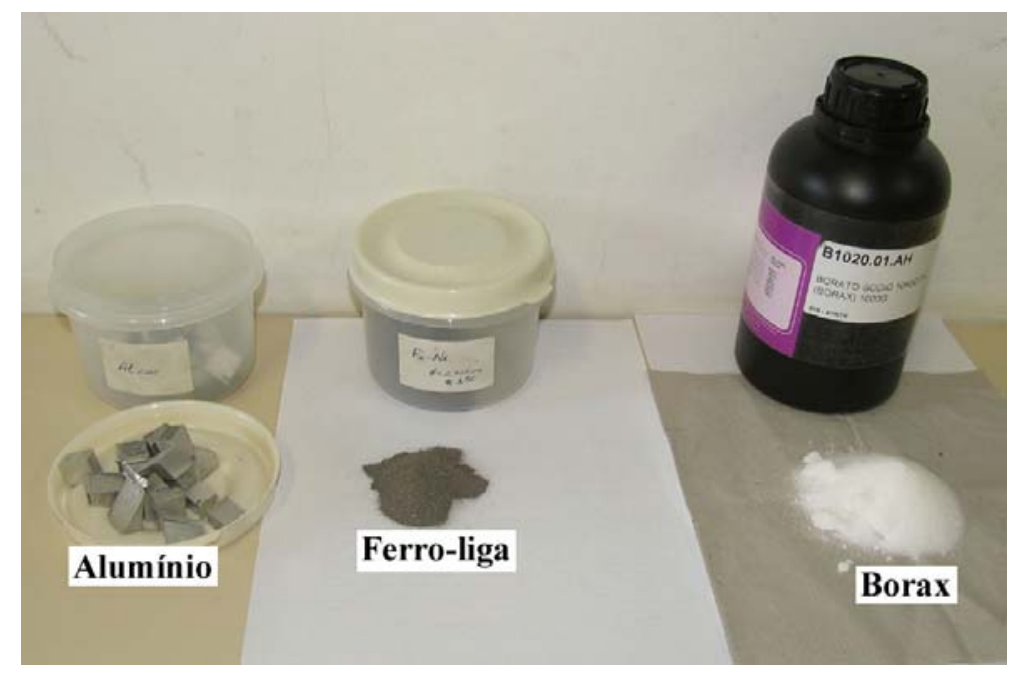

Figura 3.1 - Componentes utilizados nos banhos de bórax.

\subsection{Metodologia}

Um fluxograma do processo, mostrando os tratamentos realizados nos aços AISI H13 e D2 e as análises realizadas nas amostras tratadas, é apresentado na figura 3.2. 


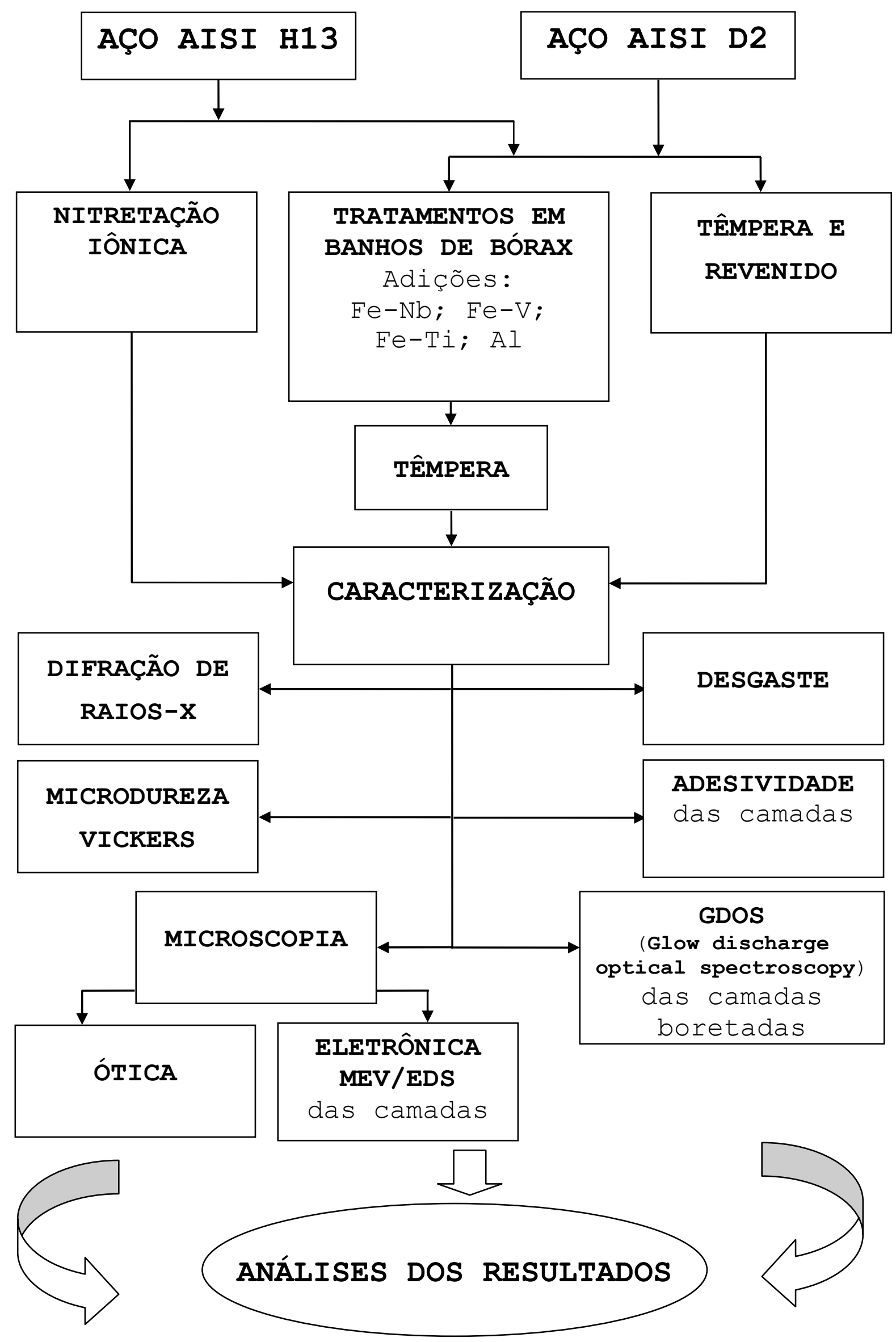

Figura 3.2 - Fluxograma do processo utilizado na presente pesquisa. 


\subsubsection{Determinação das composições químicas dos aços AISI H13 e D2}

As composições químicas dos aços AISI H13 e D2 foram determinadas por via úmida, no Laboratório de Análises Químicas do Departamento de Engenharia de Materiais, Aeronáutica e Automobilístca (SMM) da EESC/USP.

\subsubsection{Determinação das composições químicas dos ferros-ligas e do alumínio}

As composições químicas dos ferros-ligas (Fe-V e Fe-Ti) e do alumínio adicionados aos banhos foram determinas por via úmida, no Laboratório de Análises Químicas-SMM/EESC/USP. A liga Fe-Nb foi analisada também por via úmida, no Centro de Caracterização e Desenvolvimento de Materiais (CCDM) da Universidade Federal de São Carlos (UFSCar).

\subsubsection{Obtenção dos pós de ferros-ligas}

Os ferros-ligas (Fe-Nb, Fe-V e Fe-Ti) foram adicionados aos banhos em forma de pó, com tamanho de partículas inferiores a $105 \mu \mathrm{m}$, obtidos após fragmentação por martelamento manual e peneiramento $(\phi<105 \mu \mathrm{m})$.

\subsubsection{Usinagem dos corpos de prova e confecção dos cadinhos}

As amostras dos aços AISI H13 e D2 foram preparadas para os tratamentos mediante corte, fresamento e lixamento (até a lixa $n^{\circ} 600$ ). Suas dimensões foram $22 \mathrm{~mm} \times 20 \mathrm{~mm} \times 5 \mathrm{~mm}$ para o aço AISI D2 e $\phi 30 \mathrm{~mm} \times 5 \mathrm{~mm}$ para o aço AISI H13.

Os cadinhos utilizados na preparação dos banhos foram obtidos a partir de tubos do aço inoxidável 316, mediante corte e soldagem. As suas dimensões foram 90mm de diâmetro interno, $140 \mathrm{~mm}$ de profundidade e $3 \mathrm{~mm}$ de espessura. 


\subsubsection{Têmpera e revenido dos aços AISI H13 e D2}

A têmpera e o revenido dos aços AISI H13 e D2 ocorreram segundo os parâmetros mostrados na tabela 3.1. As amostras submetidas à têmpera foram protegidas com carvão vegetal, em uma caixa metálica. No revenido, o aquecimento ocorreu imediatamente após a têmpera, sem proteção das peças. Nos dois casos utilizou-se um forno tipo mufla.

Tabela 3.1: Parâmetros da têmpera e do revenido realizados nos aços AISI H13 e D2.

\begin{tabular}{||c|c|c|c|c|c|c||}
\hline \multirow{2}{*}{ Aço } & \multicolumn{3}{|c|}{ Têmpera } & \multicolumn{3}{c||}{ Revenido } \\
\cline { 2 - 7 } & $\mathrm{T}\left({ }^{\circ} \mathrm{C}\right)$ & $\mathrm{t}(\mathrm{h})$ & Resf. & $\mathrm{T}\left({ }^{\circ} \mathrm{C}\right)$ & $\mathrm{t}(\mathrm{h})$ & Resf. \\
\hline $\mathrm{H} 13$ & 1020 & 1 & Óleo & 540 & 2 & $\mathrm{Ao} \mathrm{Ar}$ \\
\hline $\mathrm{D} 2$ & 1000 & 1 & Óleo & 300 & 2 & $\mathrm{Ao} \mathrm{Ar}$ \\
\hline
\end{tabular}

\subsubsection{Nitretação lônica do aço AISI H13}

$\mathrm{O}$ aço AISI $\mathrm{H} 13$ foi nitretado ionicamente segundo as condições apresentadas na tabela 3.2 (Muñoz Riofano e Casteletti, 1999). As amostras foram lixadas até a lixa $n^{\circ} 600$ e em seguida submetidas à limpeza ultrassônica em álcool etílico durante $12 \mathrm{~min}$. Os tratamentos foram realizados em amostras previamente temperadas e revenidas.

Tabela 3.2 - Parâmetros do tratamento de nitretação iônica realizado no aço AISI H13.

\begin{tabular}{||c|c|c|c|c||}
\hline Tratamento & $\begin{array}{c}\mathrm{T} \\
\left({ }^{\circ} \mathrm{C}\right)\end{array}$ & $\begin{array}{c}\mathbf{t} \\
(\mathrm{h})\end{array}$ & $\mathbf{P}$ (mbar) & $\begin{array}{c}\text { Composição } \\
\text { do Gás }\end{array}$ \\
\hline Nitretação & 550 & 5 & 5 & $80 \% \mathrm{H}_{2}+20 \% \mathrm{~N}_{2}$ \\
\hline
\end{tabular}

O equipamento utilizado foi um reator com câmara cilíndrica de aço inoxidável medindo $30 \mathrm{~cm}$ de diâmetro e $30 \mathrm{~cm}$ de altura, no Laboratório de Engenharia de Superfície-SMM/EESC/USP. Esse equipamento possui uma fonte 
com tensão máxima de saída de $800 \mathrm{~V}$, corrente contínua, e uma potência de $2 \mathrm{kVA}$. Pode-se obter também uma tensão pulsada com freqüência variável de 1 a $10 \mathrm{kHz}$.

\subsubsection{Tratamentos termo-reativos em banhos de bórax}

Os tratamentos termo-reativos ocorreram em banhos compostos de bórax fundido com adição de ferro-liga e alumínio ou apenas de alumínio, conforme mostrado na tabela 3.3.

Tabela 3.3 - Composições dos banhos usados nos tratamentos termoreativos.

\begin{tabular}{|c|c|}
\hline Grupo & Composição do banho (\% em massa) \\
\hline $\begin{array}{c}\text { 1.Ferro-liga } \\
+ \\
\text { alumínio }\end{array}$ & $\begin{array}{l}\text { 1. } \mathrm{Na}_{2} \mathrm{~B}_{4} \mathrm{O}_{7}+(16 \% \mathrm{Fe}-\mathrm{Nb}+3 \% \mathrm{Al}) \\
\text { 2. } \mathrm{Na}_{2} \mathrm{~B}_{4} \mathrm{O}_{7}+(10 \% \mathrm{Fe}-\mathrm{V}+3 \% \mathrm{Al}) \\
\text { 3. } \mathrm{Na}_{2} \mathrm{~B}_{4} \mathrm{O}_{7}+(10 \% \mathrm{Fe}-\mathrm{Ti}+5 \% \mathrm{Al}) \\
\text { 4. } \mathrm{Na}_{2} \mathrm{~B}_{4} \mathrm{O}_{7}+(10 \% \mathrm{Fe}-\mathrm{Ti}+5 \% \mathrm{Fe}-\mathrm{Nb}+3 \% \mathrm{Al})\end{array}$ \\
\hline 2. Alumínio & $\begin{array}{ll}\text { 5. } & \mathrm{Na}_{2} \mathrm{~B}_{4} \mathrm{O}_{7}+(5 \% \mathrm{Al}) \\
\text { 6. } & \mathrm{Na}_{2} \mathrm{~B}_{4} \mathrm{O}_{7}+(10 \% \mathrm{Al}) \\
\text { 7. } & \mathrm{Na}_{2} \mathrm{~B}_{4} \mathrm{O}_{7}+(15 \% \mathrm{Al})\end{array}$ \\
\hline
\end{tabular}

Utilizou-se um forno tipo "poço" com aquecimento por resistência elétrica. O bórax foi fundido em um cadinho de aço inoxidável, e em seguida adicionou-se o ferro-liga e o alumínio. O banho foi agitado, para uma melhor dissolução dos aditivos. As amostras foram introduzidas nos banhos após lixamento até a lixa $n^{\circ}$ 600.

Os tratamentos foram realizados à $1000^{\circ} \mathrm{C}$, durante $4 \mathrm{~h}$, em atmosfera ambiente. Em alguns casos, uma temperatura de tratamento de $800^{\circ} \mathrm{C}$ ou uma duração de $9 \mathrm{~h}$ foi usada, com o objetivo de se investigar o efeito desses parâmetros. As temperaturas dos banhos foram medidas usando um termopar do tipo cromel-alumel. As amostras foram resfriadas em óleo, a temperatura ambiente, diretamente do banho, com agitação. 


\subsubsection{Caracterização das amostras}

\subsubsection{Microscopia ótica}

As amostras foram cortadas transversalmente às camadas e preparadas segundo a seqüência: Embutimento em baquelite, lixamento (até lixa $n^{\circ} 2000$ ), polimento (em alumina de $0,05 \mu \mathrm{m}$ ) e ataque. Os reagentes utilizados nos ataques foram o Nital a $3 \%$ ou o reagente de Vilella $(100 \mathrm{ml}$ de álcool etílico, $5 \mathrm{ml}$ de ácido clorídico e $1 \mathrm{~g}$ de ácido pícrico).

As calotas de desgaste foram analisadas diretamente no microscópio, sem a necessidade de preparação prévia.

O equipamento utilizado foi um Microscópio ótico Carl-Zeiss, modelo Axiotech, com um analisador de imagens acoplado.

\subsubsection{Microscopia eletrônica de varredura (MEV) com Espectrometria de dispersão de energia (EDS)}

As camadas de carbonetos e de boretos, assim como as superfícies de desgaste obtidas nos ensaios de desgaste em micro-escala, foram analisadas em um Microscópio Eletrônico de Varredura equipado com um Espectrômetro de Dispersão de Energia (EDS), com o objetivo de se realizar a microanálise elementar.

As amostras foram cortadas transversalmente às camadas, embutidas em baquelite, polidas e atacadas com nital à $3 \%$ ou com reagente de Vilella. No caso das calotas de desgaste, suas superfícies foram analisadas da forma como obtidas no ensaio de desgaste em micro-escala.

As camadas obtidas nos banhos contendo $10 \% \mathrm{Fe}-\mathrm{Ti} / 5 \% \mathrm{Al}, 10 \% \mathrm{Fe}-$ $\mathrm{Ti} / 5 \% \mathrm{Fe}-\mathrm{Nb} / 3 \% \mathrm{Al}$ e $15 \% \mathrm{Al}$, foram analisadas por MEV/EDS em suas seções transversais, em pontos das camadas e dos substratos. Uma parte destas análises foi realizada em um Microscópio Eletrônico de Varredura do tipo DSM960-ZEISS, 
no Laboratório de Microscopia e Análise, no IFSC/USP, enquanto a outra parte foi analisada utilizando-se um Microscópio Eletrônico de Varredura, da marca LEO, modelo Stereosacan 440, no Centro de Caracterização e Desenvolvimento de Materiais-CCDM, da UFSCar.

As camadas produzidas nos banhos contendo $16 \% \mathrm{Fe}-\mathrm{Nb} / 3 \% \mathrm{Al}$ e $10 \% \mathrm{Fe}-$ $\mathrm{V} / 3 \% \mathrm{Al}$, assim como todas as calotas de desgaste foram analisadas em um Microscópio eletrônico de varredura do tipo LEO-440, no Laboratório de Microscopia Eletrônica do Instituto de Química de São Carlos-IQSC/USP. As análises das camadas ocorreram com uma varredura em linha, da superfície da camada em direção ao substrato. As calotas de desgaste foram analisadas em pontos das superfícies de desgaste e em um ponto fora da calota, para comparação.

\subsubsection{Difração de Raios-X}

Os ensaios por difração de raios- $X$ das camadas e dos substratos foram realizados utilizando-se radiação de cobre $(1,54 \AA)$, com o feixe incidindo sobre as superfícies das amostras. Utilizou-se varredura contínua, com uma velocidade de 1\%min. As amostras foram ensaiadas no Laboratório de Raios-X do Instituto de Física de São Carlos-IFSC/USP, utilizando um difratômetro Rigaku Gergerflex, com o ângulo de varredura $2 \theta$ variando de 30 a $120^{\circ}$, e no CCDM/UFSCar, em um difratômetro Siemens D5000, com $2 \theta$ na faixa de 20 a $90^{\circ}$. Os difratogramas de raios-X foram utilizados para se determinar as fases presentes nos substratos e nas camadas obtidas em todos os tratamentos realizados.

\subsubsection{GDOS (glow discharge optical emission spectroscopy)}

Os perfis dos elementos boro, ferro, carbono e cromo foram determinados quantitativamente por GDOS. As amostras foram enviadas ao Laboratório da 
Empresa LECO Instrumenta Ltda, St. Joseph-MI, USA, e as análises foram realizadas no equipamento LECO GDS-850A. Tal tipo de ensaio permite a determinação progressiva da composição química da camada, da superfície até o substrato.

\subsubsection{Medições das espessuras das camadas}

As espessuras das camadas foram determinadas por meio de leituras realizadas em um microscópio ótico com um micrômetro acoplado. No caso das camadas de boretos, que apresentam uma interface irregular com o substrato, as medições foram realizadas segundo mostra a figura 3.3.

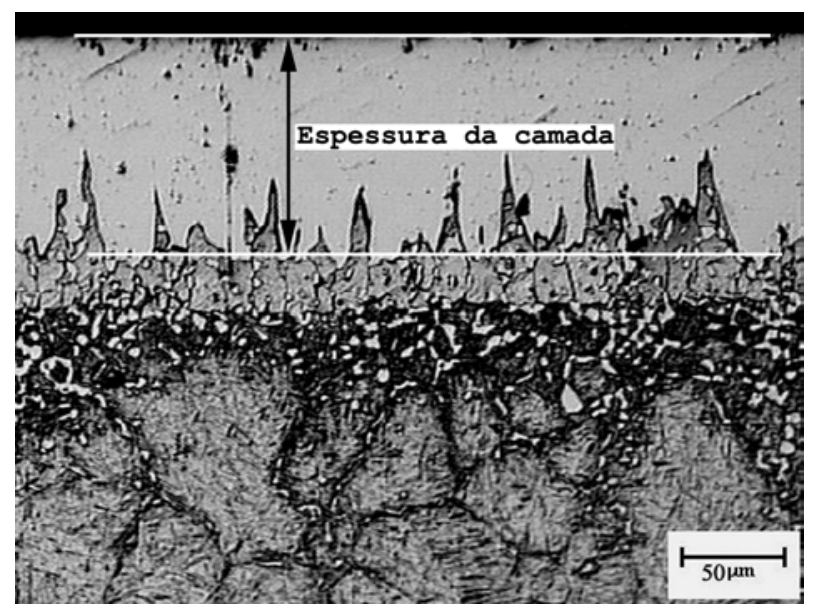

Figura 3.3 - Esquema mostrando a medição da espessura de uma camada de boreto, produzida no aço AISI H13 [Adaptado de Oliveira e Casteletti, 2004].

\subsubsection{Microdureza Vickers}

As medidas de microdurezas Vickers foram obtidas utilizando-se um microdurômetro digital (Micromet 2104), aplicando-se uma carga de 50gf. As amostras dos aços AISI H13 e D2 temperadas e revenidas, as camadas de carbonetos obtidas nesses dois aços e a camada nitretada formada no aço AISI H13, foram ensaiadas nas superfícies (dureza de topo). As camadas de carbonetos 
necessitaram ser ensaiadas na superfície devido as suas espessuras relativamente baixas. As medições das durezas das camadas boretadas foram realizadas nas suas seções transversais. Os valores de microdurezas apresentados são valores médios obtidos a partir de dez medições, para as camadas de carbonetos e de seis medições para as demais amostras.

\subsubsection{Ensaio de adesividade das camadas}

A aderência das camadas foi avaliada por meio de um indentador Vickers, aplicando-se cargas nas interfaces camada/substrato, com o objetivo de avaliar uma possível formação de trinca ao longo da interface ou destacamento da camada. As cargas aplicadas variaram de 25 a 1000gf, dependendo da espessura da camada. O equipamento usado foi um microdurômetro digital, Micromet 2104.

\subsubsection{Ensaios de desgaste em micro-escala}

Os ensaios de desgaste em micro-escala com a "esfera livre" e com a "esfera fixada" (Gee et al., 2003), foram utilizados no presente trabalho. Nos dois casos, o princípio do ensaio é a rotação de uma esfera na superfície da amostra, para obtenção de uma calota de desgaste, conforme apresenta-se a seguir.

\subsubsection{Ensaio de desgaste em micro-escala com a "esfera livre"}

Os testes de desgaste com a esfera "livre" (Fig. 3.4) foram realizados com adição de abrasivo, sendo tipicamente um ensaio de desgaste micro-abrasivo, e tiveram como objetivo revelar as camadas em uma outra perspectiva, além de sua seção transversal mostrada comumente pela micrografia ótica, assim como determinar as espessuras das camadas de carbonetos de acordo com a figura $3.5 \mathrm{e}$ a Eq. (3.1) (Págs. 41 e 42). Suspensões de alumina e de diamante, nesta 
seqüência, foram usadas como "lamas" abrasivas. A rotação do eixo foi de 800rpm o que resulta em uma velocidade linear da esfera de $61,5 \mathrm{~cm} / \mathrm{s}$ (Staia et al., 1998).

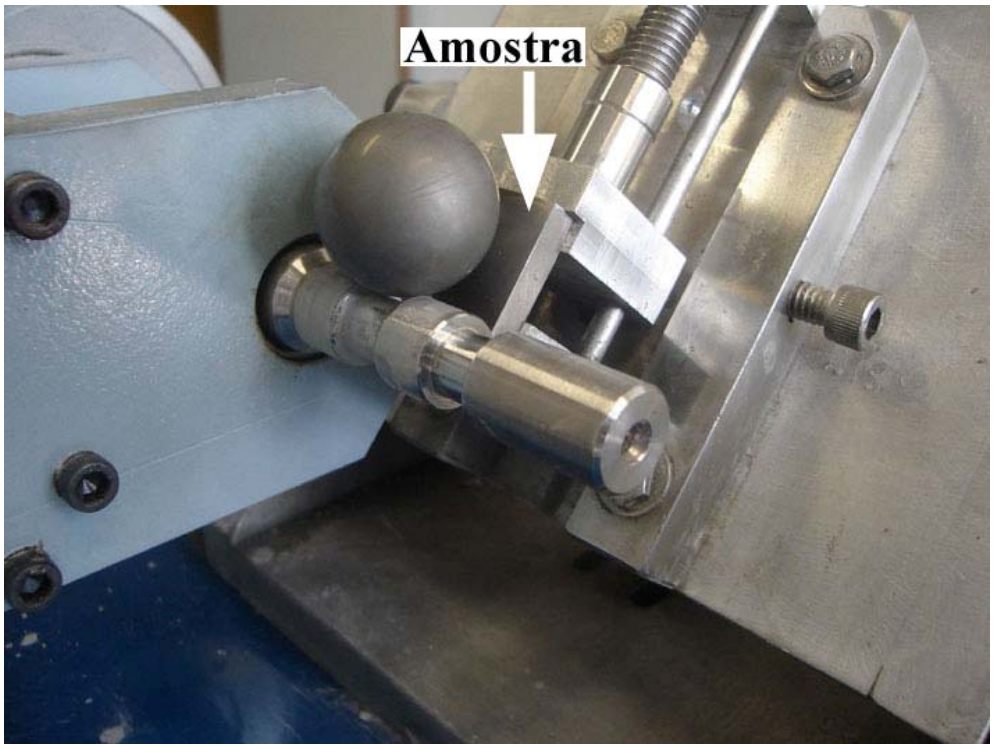

Figura 3.4 - Equipamento utilizado no ensaio de desgaste micro-abrasivo com a esfera "livre" (CALOTEST), mostrando o eixo, a esfera e a amostra.

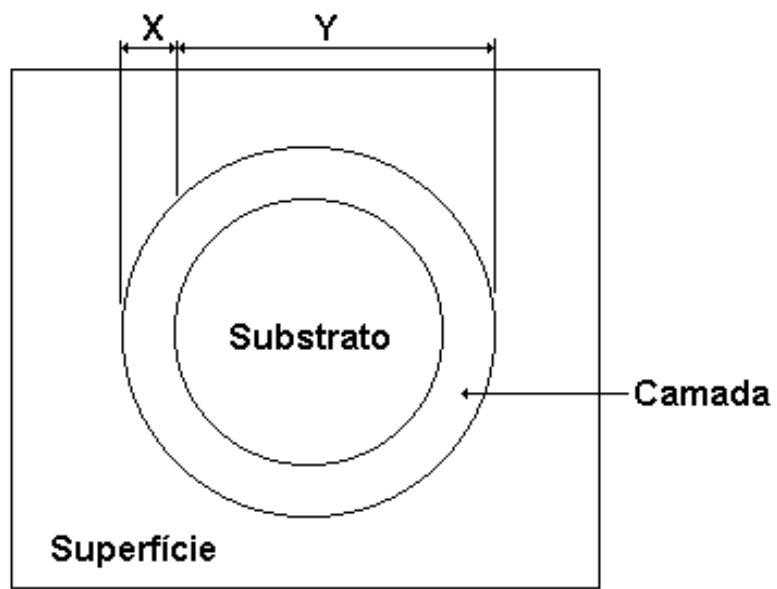

Figura 3.5 - Esquema do aspecto da camada obtido após o ensaio de desgaste micro-abrasivo com a esfera "livre". 


$$
e=\alpha(X \times Y)
$$

Sendo:

e: espessura da camada

$\alpha=1 / D$, onde $D$ é o diâmetro da esfera, $25,4 \mathrm{~mm}$

$X$ e $Y$ : medidos de acordo com a figura 3.5

\subsubsection{Ensaio de desgaste em micro-escala com a esfera "fixada"}

Neste tipo do ensaio, o comportamento ao desgaste das amostras foi avaliado utilizando-se um equipamento construído no Laboratório de Engenharia de Superfície (SMM/EESC-USP), mostrado na figura 3.6. Os volumes das calotas de desgaste das camadas e dos substratos foram determinados e definidos como os volumes de desgaste. Os testes foram realizados sem a adição de abrasivo, aplicando-se uma carga normal na superfície da amostra $\left(F_{N}\right)$ de $18,7 \mathrm{~N}$. Utilizou-se uma esfera do aço para rolamento AISI 52100, temperado, com dureza de $850 \mathrm{HV}$ e diâmetro de 25,4mm. Sua rotação foi de 148rpm, o que corresponde a uma velocidade linear superficial (velocidade de deslizamento) de $19,7 \mathrm{~cm} / \mathrm{s}$. Para cada amostra, uma série de cinco experimentos foi realizada, conforme as condições apresentadas na tabela 3.4 , onde $t_{s}$ é o tempo de cada experimento, $N_{R}$ o número de revoluções e $D_{S}$ a distância de deslizamento.

Tabela 3.4 - Parâmetros utilizados nos testes de desgaste em micro-escala.

\begin{tabular}{|c|c|c||}
\hline $\mathrm{t}_{\mathrm{S}}(\min )$ & $\mathrm{N}_{\mathrm{R}}(\mathrm{rev})$. & $\mathrm{D}_{\mathrm{S}}(\mathrm{m})$ \\
\hline 5 & 740 & 59 \\
\hline 10 & 1480 & 118,1 \\
\hline 15 & 2220 & 177,1 \\
\hline 20 & 2960 & 236,2 \\
\hline 25 & 3700 & 295,2 \\
\hline
\end{tabular}




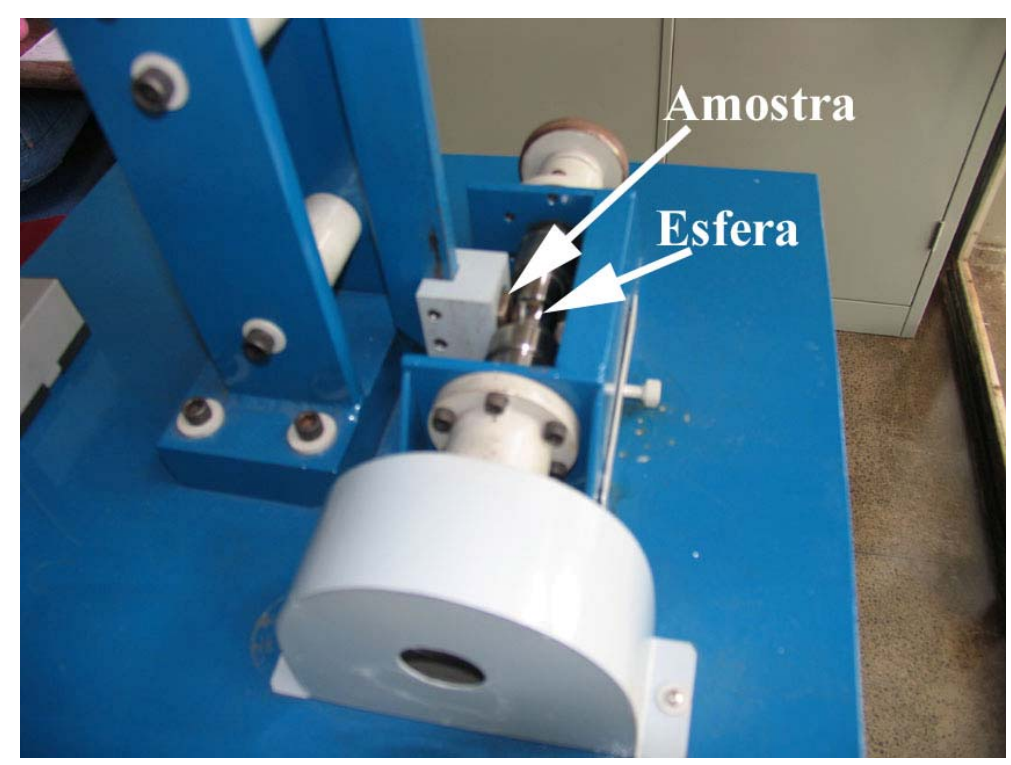

Figura 3.6 - Equipamento utilizado no ensaio de desgaste em micro-escala, com a esfera "fixada".

Um microscópio ótico foi usado para determinar os diâmetros das calotas de desgaste (d) e identificar os mecanismos de desgaste. As superfícies de desgaste foram analisadas também em um microscópio eletrônico, e as análises químicas elementares foram realizadas por EDS.

O volume de desgaste (V) foi calculado de acordo com a Eq. (3.2), que é válida quando a camada não é perfurada (Gee et al., 2003). Os diâmetros das calotas (d) foram determinados de acordo com a Eq. (3.3) e a figura 3.7.

$$
V=\frac{\pi d^{4}}{64 R}, \text { para } d<R
$$

Onde, d: diâmetro médio da calota de desgaste, determinado segundo a Eq. (3.3) e a figura 3.7.

$R$ : raio da esfera, $12,7 \mathrm{~mm}$. 
$d=\frac{d_{1}+d_{2}}{2}$

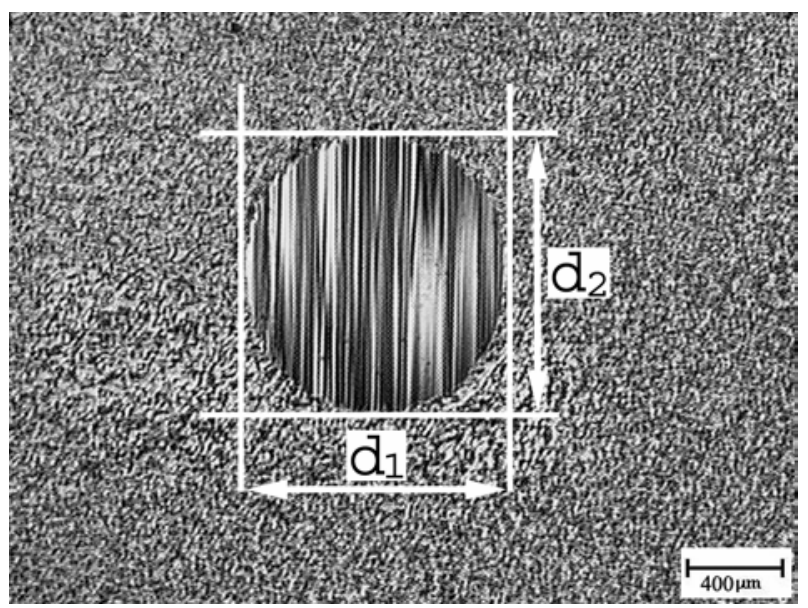

Figura 3.7 - Esquema mostrando a determinação do diâmetro da calota de desgaste em micro-escala. Calota formada em uma camada de $\mathrm{NbC}$ sobre o aço AISI D2, para uma distância de deslizamento de 295m.

Os resultados decorrentes das caracterizações descritas no presente capítulo, com as devidas discussões, são apresentados no capítulo seguinte. 


\section{RESULTADOS E DISCUSSÃO}

\subsection{Composições químicas dos aços AISI H13 e D2}

As composições químicas dos aços AISI H13 e D2 utilizados no presente trabalho são apresentadas na tabela 4.1, onde se verifica que as composições químicas obtidas estão dentro da faixa das composições nominais. Nas tabelas 4.2 a 4.4 são apresentadas as composições químicas dos ferros-ligas usados e na tabela 4.5 a composição do alumínio.

Tabela 4.1 - Composições químicas dos aços AISI H13 e D2 (\% em peso)

\begin{tabular}{|c|c|c|c|c|c|c|c|}
\hline Aço & $\mathbf{C}$ & $\mathbf{C r}$ & $\mathbf{M o}$ & $\mathbf{V}$ & $\mathbf{S i}$ & $\mathbf{M n}$ & $\mathbf{F e}$ \\
\hline $\begin{array}{c}\text { AISI H13 } \\
\text { (obtida) }\end{array}$ & 0,39 & 5,17 & 1,46 & 0,94 & 1,04 & 0,38 & Bal. \\
\hline $\begin{array}{c}\text { AISI H13 } \\
\text { (nominal) }\end{array}$ & $\begin{array}{c}0,32- \\
0,45\end{array}$ & $\begin{array}{c}4,75- \\
5,5\end{array}$ & $\begin{array}{c}1,1- \\
1,75\end{array}$ & $0,8-1,2$ & $0,8-1,2$ & $0,2-0,5$ & Bal. \\
\hline $\begin{array}{c}\text { AISI D2 } \\
\text { (obtida) }\end{array}$ & 1,48 & 11,91 & 0,98 & 0,76 & 0,96 & 0,45 & Bal. \\
\hline $\begin{array}{c}\text { AISI D2 } \\
\text { (nominal) }\end{array}$ & $1,4-1,6$ & $\begin{array}{c}11,0- \\
13,0\end{array}$ & $0,7-1,2$ & $\begin{array}{c}1,1 \\
\text { máx. }\end{array}$ & $\begin{array}{c}0,6 \\
\text { máx. }\end{array}$ & $\begin{array}{c}0,6 \\
\text { máx. }\end{array}$ & Bal. \\
\hline
\end{tabular}

Tabela 4.2 - Composição química da liga Fe-Nb (\% em peso)

\begin{tabular}{||c|c|c|c|c|c|c|c||}
\hline $\mathbf{C}$ & $\mathbf{M n}$ & $\mathbf{P}$ & $\mathbf{S}$ & $\mathbf{S i}$ & $\mathbf{A l}$ & $\mathbf{F e}$ & $\mathbf{N b}$ \\
\hline 0,066 & 0,14 & 0,005 & 0,029 & 6,33 & 0,27 & 30,12 & $\begin{array}{c}\text { Bal. } \\
(63,14)\end{array}$ \\
\hline
\end{tabular}

Tabela 4.3 - Composição química da liga Fe-V (\% em peso)

\begin{tabular}{||c|c|c|c|c|c|c|c||}
\hline $\mathbf{C}$ & $\mathbf{M n}$ & $\mathbf{P}$ & $\mathbf{S}$ & $\mathbf{S i}$ & $\mathbf{A l}$ & $\mathbf{F e}$ & $\mathbf{V}$ \\
\hline 0,18 & 0,50 & 0,017 & 0,026 & 0,56 & 5,86 & 46,98 & $\begin{array}{c}\text { Bal. } \\
(45,88)\end{array}$ \\
\hline
\end{tabular}


Tabela 4.4 - Composição química da liga Fe-Ti (\% em peso)

\begin{tabular}{||c|c|c|c|c|c|c|c||}
\hline $\mathbf{C}$ & $\mathbf{M n}$ & $\mathbf{P}$ & $\mathbf{S}$ & $\mathbf{S i}$ & $\mathbf{A l}$ & $\mathbf{F e}$ & $\mathbf{T i}$ \\
\hline 0,072 & 0,92 & 0,026 & 0,021 & 2,94 & 7,87 & 54,49 & $\begin{array}{c}\text { Bal. } \\
(33,66)\end{array}$ \\
\hline
\end{tabular}

Tabela 4.5 - Composição química do alumínio (\% em peso)

\begin{tabular}{||c|c|c|c|c|c||}
\hline $\mathbf{S i}$ & $\mathbf{C u}$ & $\mathbf{Z n}$ & $\mathbf{N i}$ & $\mathbf{F e}$ & $\mathbf{A l}$ \\
\hline 0,66 & 0,06 & 0,14 & 0,08 & 0,16 & Bal. \\
\hline
\end{tabular}

\subsection{Análises por microscopia ótica e difração de raios-X dos aços AISI H13 e}

D2

A micrografia ótica do aço AISI H13 é apresentada na figura 4.1, sendo sua microestrutura constituída de martensita, com a presença de carbonetos do tipo $\mathrm{M}_{7} \mathrm{C}_{3}$ como indicado pela análise de raios-X (Fig. 4.2). No aço AISI D2 a microestrutura é martensítica com a presença de carbonetos primários grosseiros (Fig. 4.3). Detectou-se por análise de raios-X a predominância dos carbonetos $\mathrm{Cr}_{7} \mathrm{C}_{3}$ e $\mathrm{Fe}_{7} \mathrm{C}_{3}$ e em menor escala, a presença do carboneto $\mathrm{Cr}_{23} \mathrm{C}_{6}$ (Fig. 4.4).

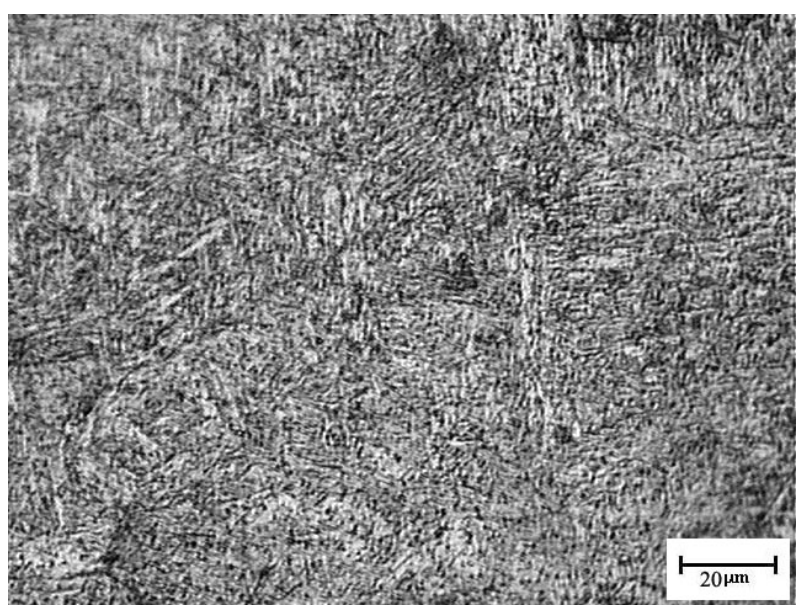

Figura 4.1 - Micrografia ótica do aço AISI H13 temperado e revenido. Microestrutura martensítica. Ataque: Reagente de Vilella. 


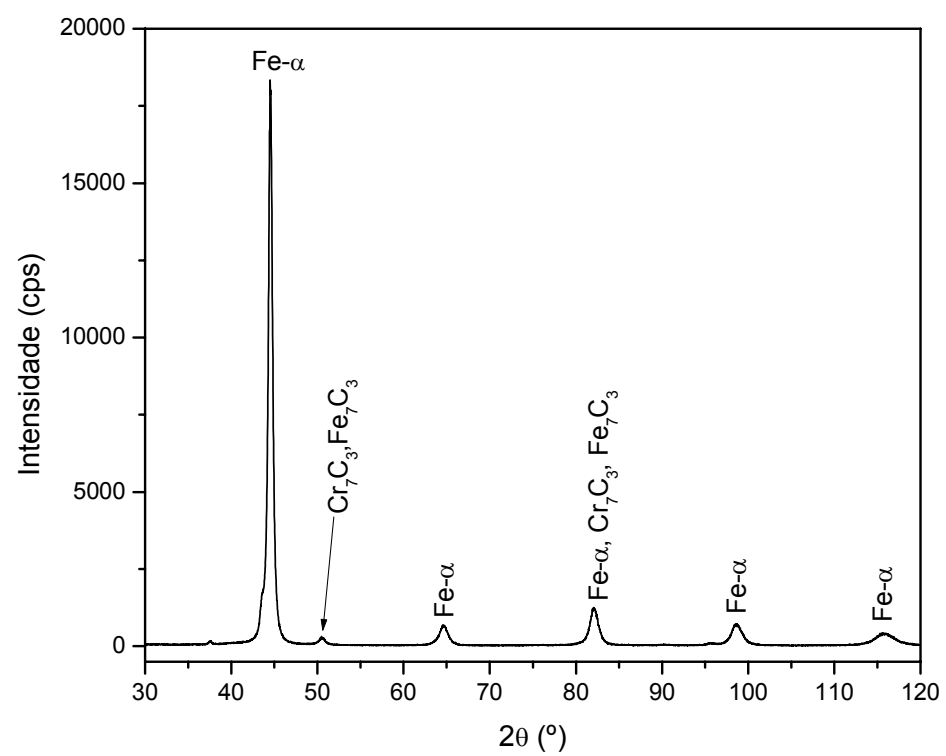

Figura 4.2 - Difratograma de raios-X do aço AISI H13 temperado e revenido.

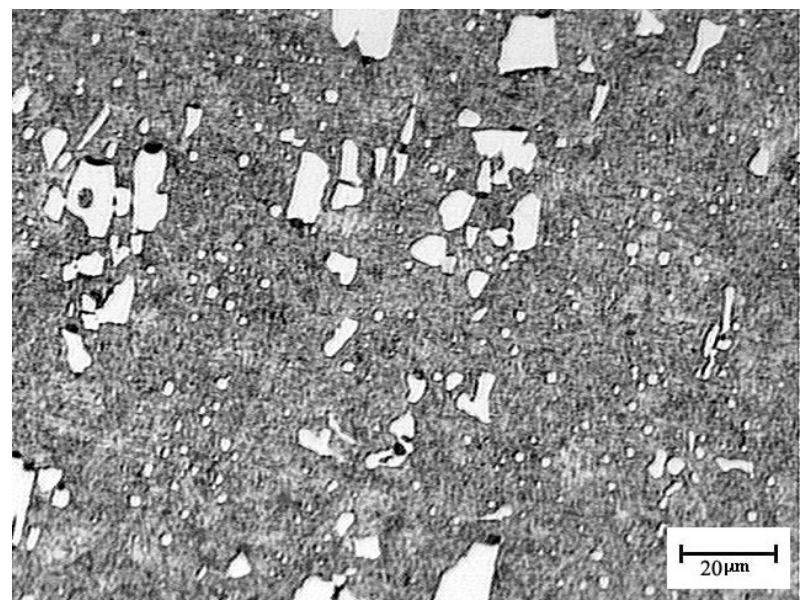

Figura 4.3 - Micrografia ótica do aço AISI D2 temperado e revenido. Microestrutura martensítica, com a presença de carbonetos. Ataque: Reagente de Vilella. 


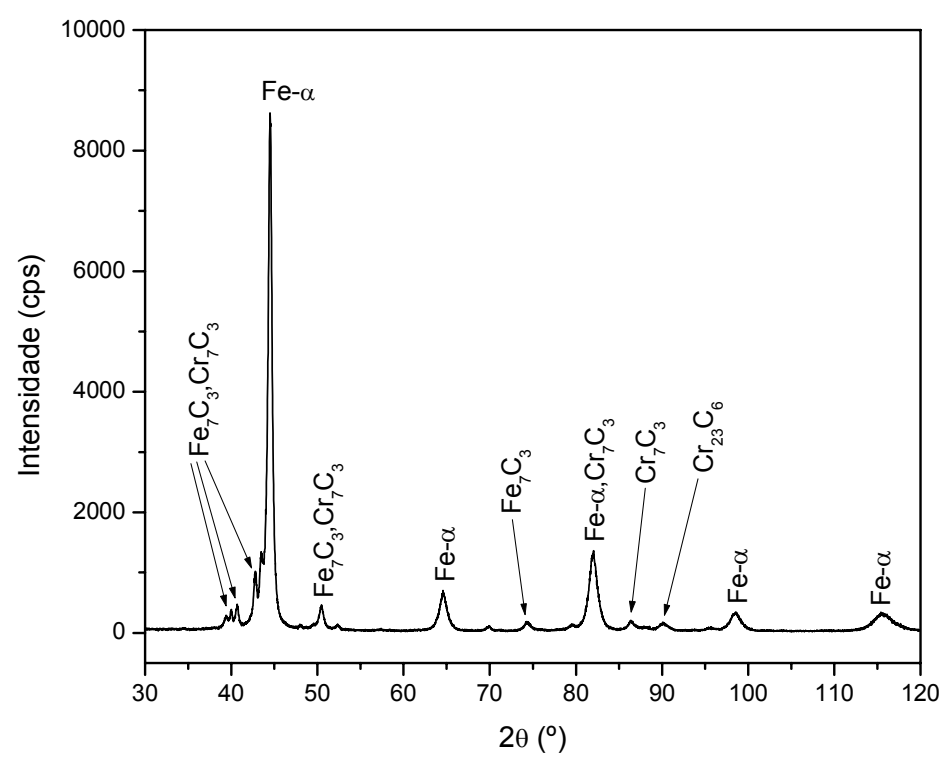

Figura 4.4 - Difratograma de raios-X do aço AISI D2 temperado e revenido.

\subsection{Nitretação iônica do aço AISI H13}

$\mathrm{O}$ aço AISI H13 foi nitretado ionicamente para a comparação de seu desempenho com as amostras tratadas em banhos de bórax, em termos de dureza e resistência ao desgaste. Na figura 4.5 apresenta-se a micrografia ótica deste aço nitretado à $550^{\circ} \mathrm{C}$ durante $5 \mathrm{~h}$, na qual se verifica a presença de uma camada de difusão espessa e uniforme. Sua espessura, obtida por microscopia ótica mediu $128,4 \pm 7,5 \mu \mathrm{m}$. A microestrutura do substrato é martensítica.

Verificou-se por difração de raios-X, conforme mostrado na figura 4.6, que a camada formada constitui-se basicamente dos nitretos $\mathrm{Fe}_{4} \mathrm{~N}\left(\gamma^{\prime}\right), \mathrm{Fe}_{3} \mathrm{~N}(\varepsilon)$ e $\mathrm{Cr}_{2} \mathrm{~N}$. 


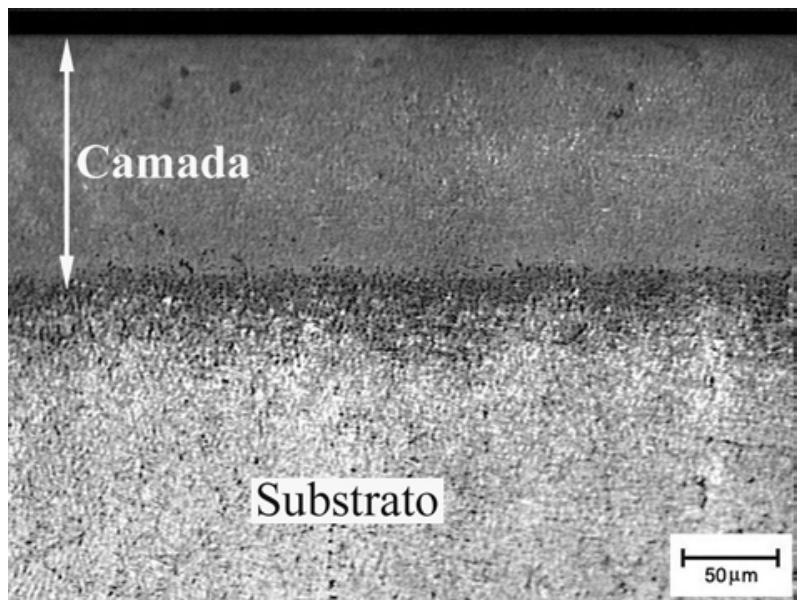

Figura 4.5 - Micrografia ótica do aço AISI H13 nitretado ionicamente, à $550^{\circ} \mathrm{C} / 5 \mathrm{~h}$. Camada de difusão sobre o substrato martensítico. Ataque: Nital 3\%.

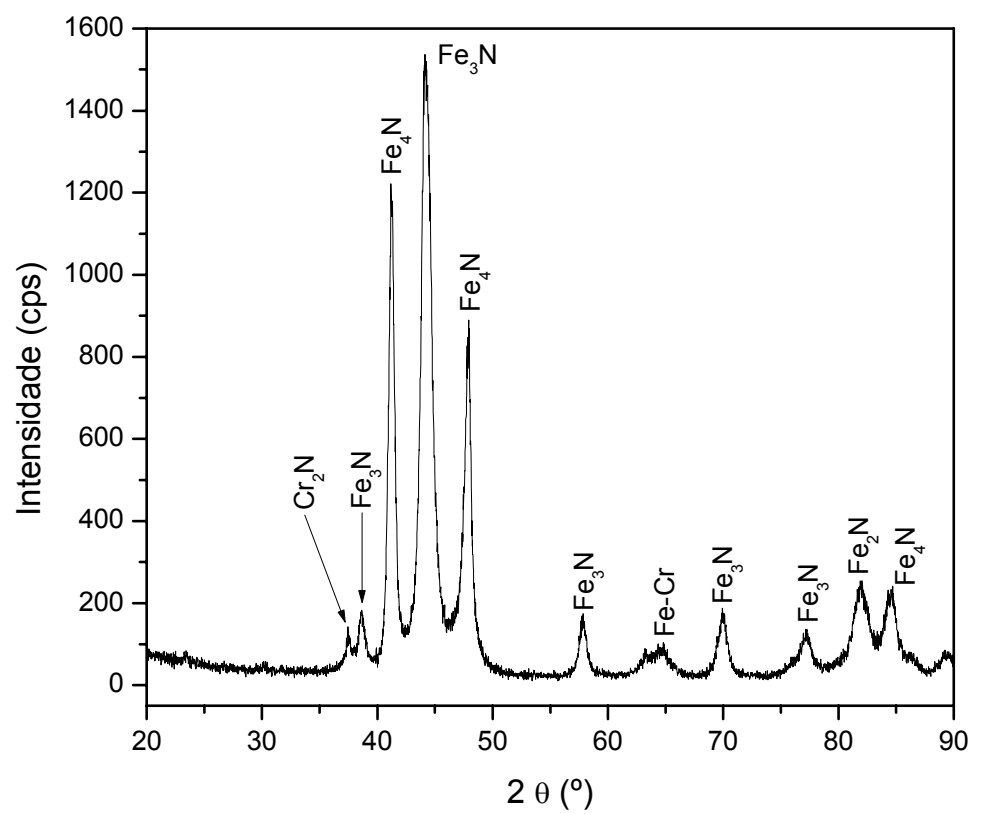

Figura 4.6 - Difratograma de raios-X da camada produzida no aço AISI H13 nitretado ionicamente, à $550^{\circ} \mathrm{C} / 5 \mathrm{~h}$.

\subsection{Tratamentos termo-reativos em banhos de bórax}

Os aços AISI H13 e D2 foram tratados em banhos de borax de diferentes composições, contendo ferro-liga (Fe-Nb, Fe-V ou Fe-Ti) e alumínio, ou com adição apenas de alumínio (Tab. 3.3, pág. 36). A seguir são apresentados os resultados obtidos em cada caso. 


\subsubsection{Tratamentos em banho de bórax contendo ferro-nióbio/alumínio}

O aço AISI H13 foi tratado no banho composto de bórax e 16\%Fe-Nb/3\%Al, a uma temperatura de $1000^{\circ} \mathrm{C}$, durante 4 e $9 \mathrm{~h}$, cujas micrografias óticas são mostradas na figura 4.7. As camadas apresentam grande regularidade, com uma interface plana com o substrato.

Verifica-se que a camada formada na amostra tratada durante 9h é mais espessa do que a obtida no tratamento de 4h. Sua espessura foi de aproximadamente $9,7 \mu \mathrm{m}$, enquanto a camada obtida no tratamento de $4 \mathrm{~h}$ apresentou uma espessura média de $6,2 \mu \mathrm{m}$. O aumento na espessura deveu-se ao maior tempo disponível para a difusão dos elementos formadores da camada. $\mathrm{Na}$ figura 4.8 mostra-se, para ilustração, uma calota de desgaste formada na superfície da amostra tratada por $4 \mathrm{~h}$, após ensaio de desgaste micro-abrasivo com a esfera solta. O anel formado pode ser relacionado matematicamente com a espessura da camada. Pode-se comprovar também aí a regularidade da espessura da camada.
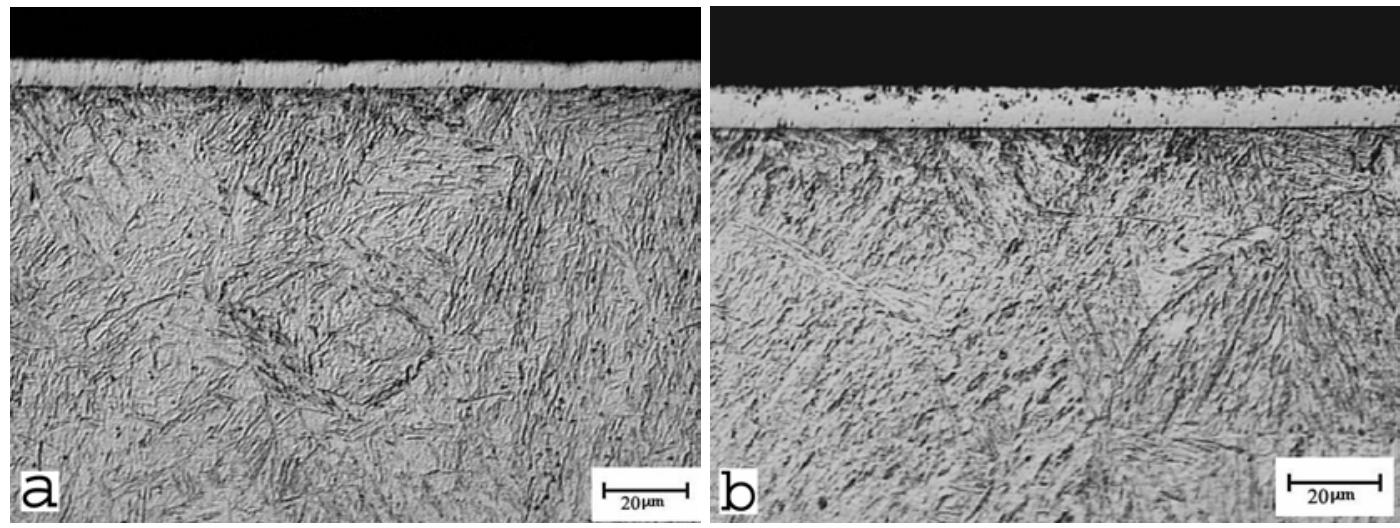

Figura 4.7 - Micrografias óticas das seções transversais do aço AISI H13 tratado no banho de bórax contendo $16 \% \mathrm{Fe}-\mathrm{Nb}+3 \% \mathrm{Al}$, à $1000^{\circ} \mathrm{C}$, durante (a) $4 \mathrm{~h}$ e (b) $9 \mathrm{~h}$. Camadas de carboneto sobre os substratos martensíticos. Ataque: Reagente de Vilella. 


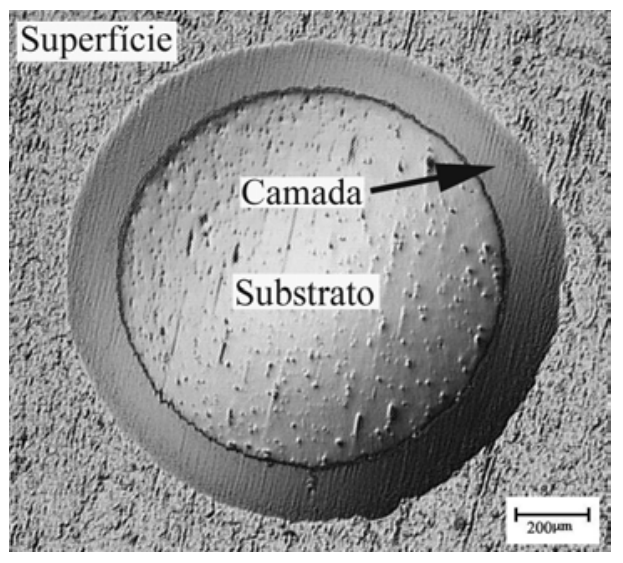

Figura 4.8 - Micrografia ótica da calota formada após ensaio de desgaste microabrasivo, para o aço AISI H13 tratado no banho de bórax contendo $16 \% \mathrm{Fe}-\mathrm{Nb}+$ $3 \% \mathrm{Al}$, à $1000^{\circ} \mathrm{C} / 4 \mathrm{~h}$.

A análise do difratograma de raios- $\mathrm{X}$ do aço $\mathrm{H} 13$ revestido segundo esse processo (figura 4.9) indica que a camada é constituída de carboneto de nióbio $(\mathrm{NbC})$. Os picos relativos às fases $\mathrm{NbC}$ estão de acordo com os obtidos por Sricharoenchai et al. (1998). Na figura 4.10 (Pág. 53) são apresentados uma fotomicrografia eletrônica e o resultado da varredura em linha (EDS), a partir da superfície da camada em direção ao substrato. A camada é rica em nióbio, que é o constituinte do carboneto presente, comprovando o resultado obtido pela análise de raios-X. 


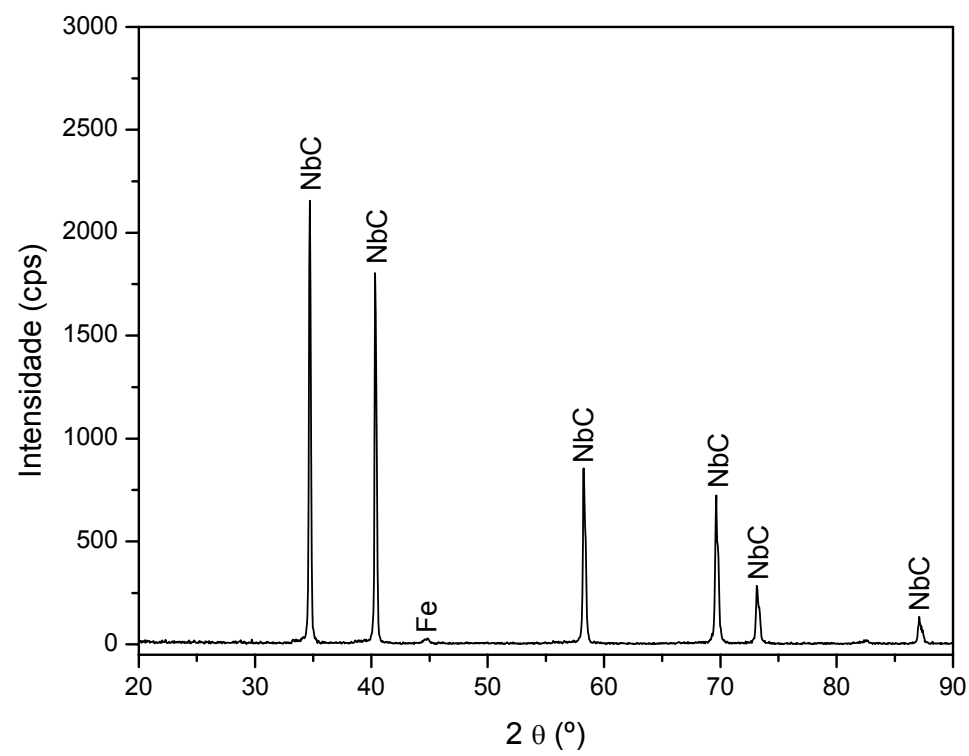

Figura 4.9 - Difratograma de raios-X do aço AISI H13 tratado em banho de bórax contendo $16 \% \mathrm{Fe}-\mathrm{Nb}+3 \% \mathrm{Al}$, à $1000^{\circ} \mathrm{C} / 4 \mathrm{~h}$.

No caso do aço AISI D2 tratado no mesmo tipo de banho, à $1000^{\circ} \mathrm{C} / 4 \mathrm{~h}$, a camada formada também apresentou regularidade em sua espessura e uma interface bem definida e plana com o substrato, conforme mostrado nas figuras 4.11a e 4.11b. Neste caso, a espessura média da camada foi de $15,6 \mu \mathrm{m}$. O difratograma de raios-X apresentado na figura 4.12 (pág. 54), indica que a camada formada no aço AISI D2 apresenta a mesma constituição da camada formada no aço AISI H13, ou seja, carboneto de nióbio ( $\mathrm{NbC}$ ). As camadas de carboneto se formaram pela combinação direta do carbono presente no substrato com o nióbio dissolvido no banho, como um resultado da baixa energia livre de formação de carboneto que o nióbio apresenta (Arai et al., 1987). Verifica-se que a composição química da camada independe da composição do substrato. Já em relação ao teor de carbono, este é um fator determinante da espessura da camada (Arai e Harper, 1991). 

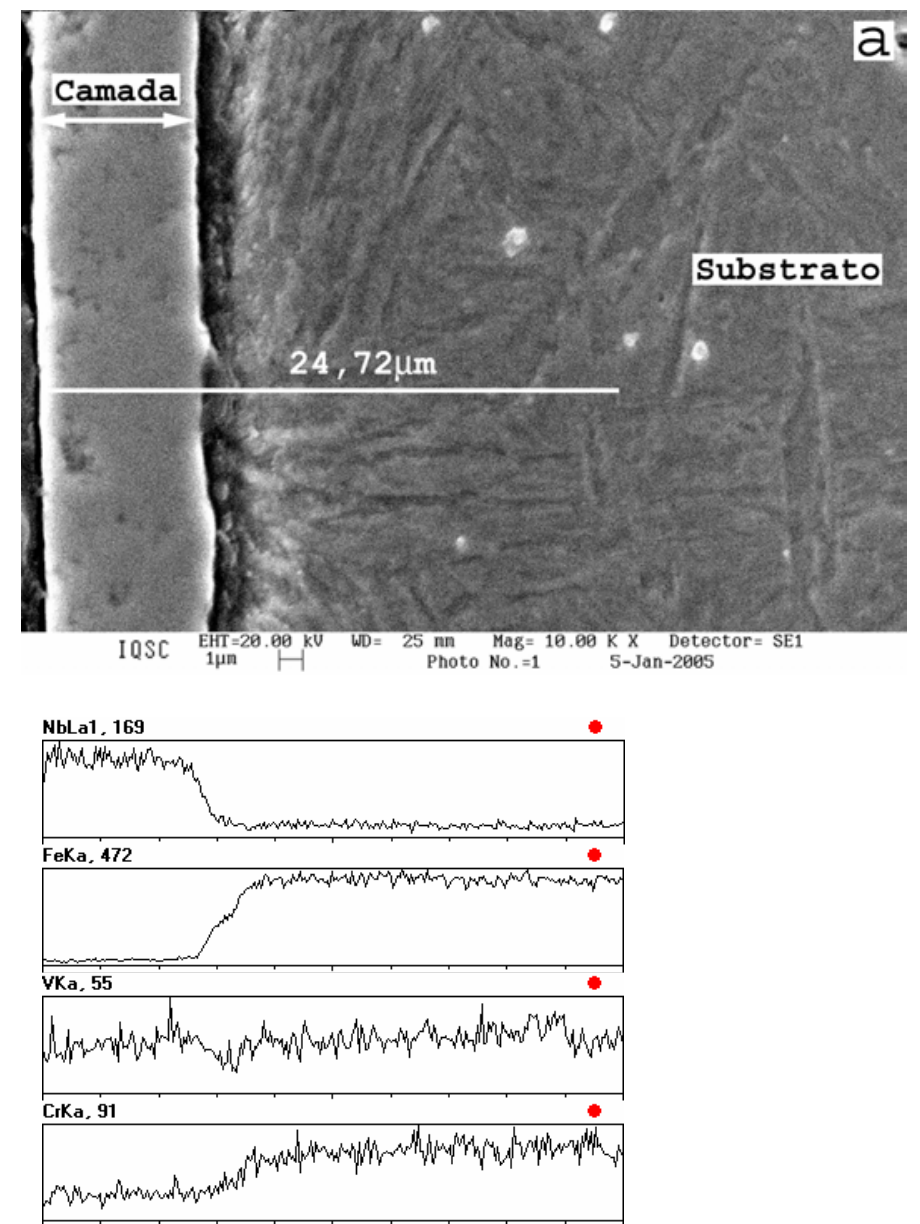

(b)

Figura 4.10 - Aço AISI H13 tratado no banho de bórax contendo 16\%Fe-Nb $+3 \% \mathrm{Al}$, $1000^{\circ} \mathrm{C} / 4 \mathrm{~h}$ : (a) Micrografia eletrônica mostrando a camada, a matriz, constituída de martensita, e a linha de varredura. Ataque: Reagente de Vilella; (b) Varredura em linha por EDS.
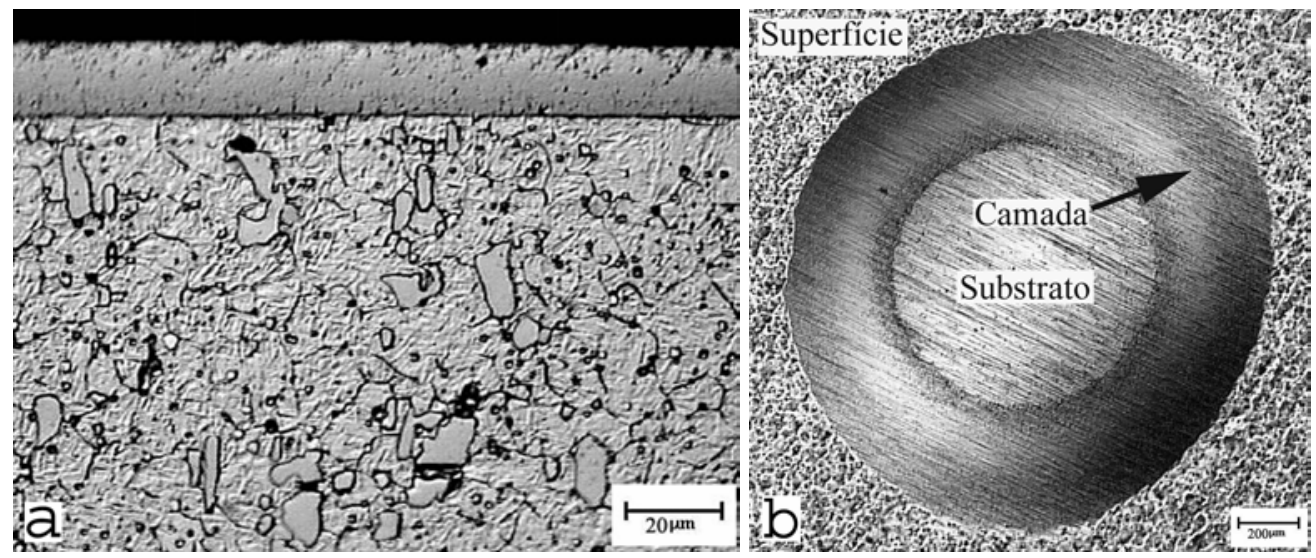

Figura 4.11 - Micrografias óticas do aço AISI D2 tratado em bórax fundido contendo $16 \% \mathrm{Fe}-\mathrm{Nb}+3 \% \mathrm{Al}$, à $1000^{\circ} \mathrm{C} / 4 \mathrm{~h}$ : (a) seção transversal. Camada sobre a matriz martensítica com carbonetos. Ataque: Nital 3\%; (b) calota formada após ensaio de desgaste micro-abrasivo. 


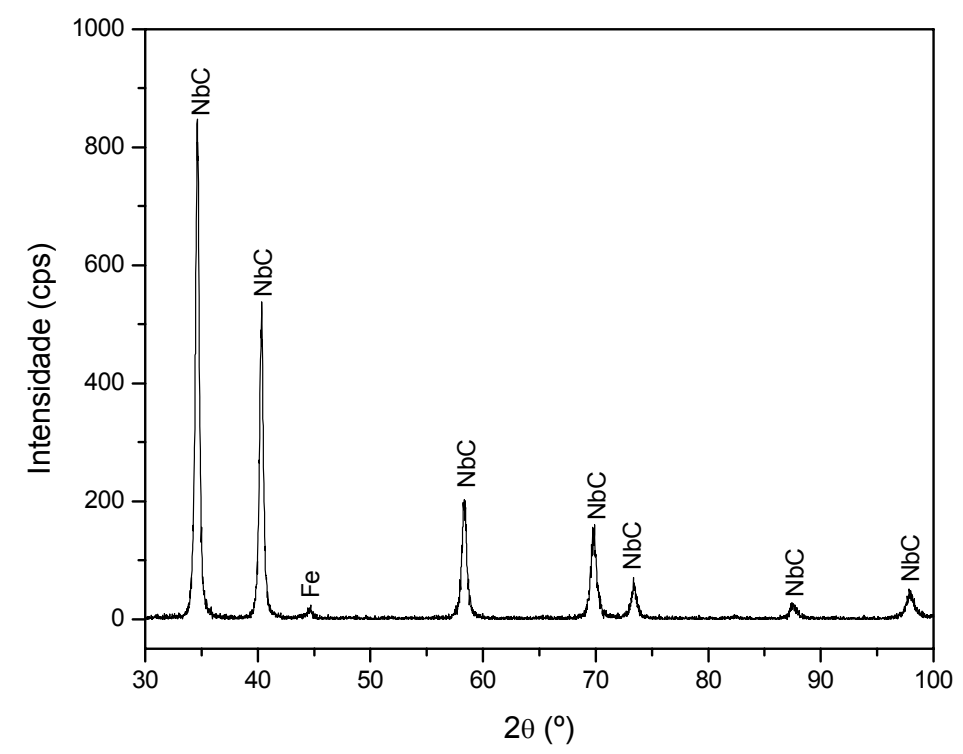

Figura 4.12 - Difratograma de raios-X do aço AISI D2 tratado em bórax fundido contendo $16 \% \mathrm{Fe}-\mathrm{Nb}+3 \% \mathrm{Al}$, à $1000^{\circ} \mathrm{C} / 4 \mathrm{~h}$.

A espessura da camada produzida no aço AISI D2 foi consideravelmente superior a da obtida no aço AISI H13, sob as mesmas condições, conforme pode ser verificado comparando-se as figuras 4.7 e 4.11 . O teor de carbono mais elevado do aço AISI D2 promoveu o fornecimento de uma quantidade de átomos de carbono maior do que no caso do aço $\mathrm{H} 13$, sendo o fator determinante para a formação de uma camada mais espessa (Arai e Harper, 1991; Plumb, 1985).

A fotomicrografia eletrônica do aço $\mathrm{D} 2$ revestido com $\mathrm{NbC}$ e o resultado da varredura em linha (EDS) a partir da superfície da camada, são apresentados na figura 4.13. A camada é rica em nióbio e não contém outros elementos, coerentemente com a análise de raios-X. 

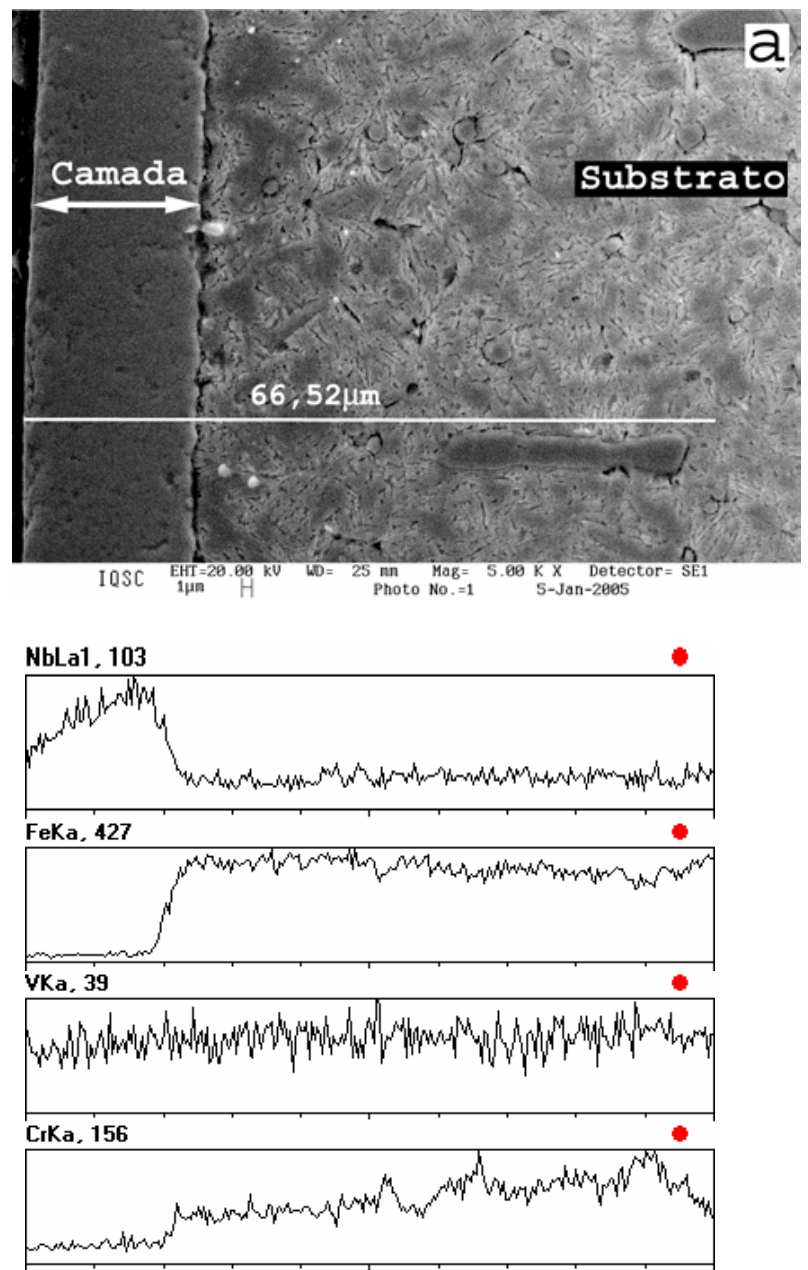

(b)

Figura 4.13 - Aço AISI D2 tratado em banho contendo 16\%Fe-Nb + 3\%Al: (a) Micrografia eletrônica mostrando a camada, a matriz, constituída de martensita e de carbonetos primários, e a linha de varredura. Ataque: Reagente de Vilella; (b) Varredura em linha por EDS.

\subsubsection{Tratamentos em banho de bórax contendo ferro-vanádio/alumínio}

Amostras dos aços AISI H13 e D2 foram tratadas também em banho de bórax contendo $10 \% \mathrm{Fe}-\mathrm{V}+3 \% \mathrm{Al}$, à $1000^{\circ} \mathrm{C}$, durante $4 \mathrm{~h}$. As camadas obtidas apresentaram uma interface bem definida com o substrato, com uma grande regularidade em suas espessuras. A micrografia ótica da seção transversal à superfície do aço AISI H13 tratado está mostrada na figura 4.14a, enquanto a calota de desgaste formada nesta superfície encontra-se na figura 4.14b. A espessura da camada mediu $5,8 \mu \mathrm{m}$. O difratograma de raios-X (Fig. 4.15) da camada indica que 
a mesma é constituída pela fase $\mathrm{VC}$, com algum ferro presente. $\mathrm{O}$ resultado da varredura em linha por EDS (Fig. 4.16), realizada a partir da superfície da camada em direção ao substrato, mostra que a camada é rica em vanádio, o que está em concordância com a identificação da fase VC realizada no difratograma de raios-X.
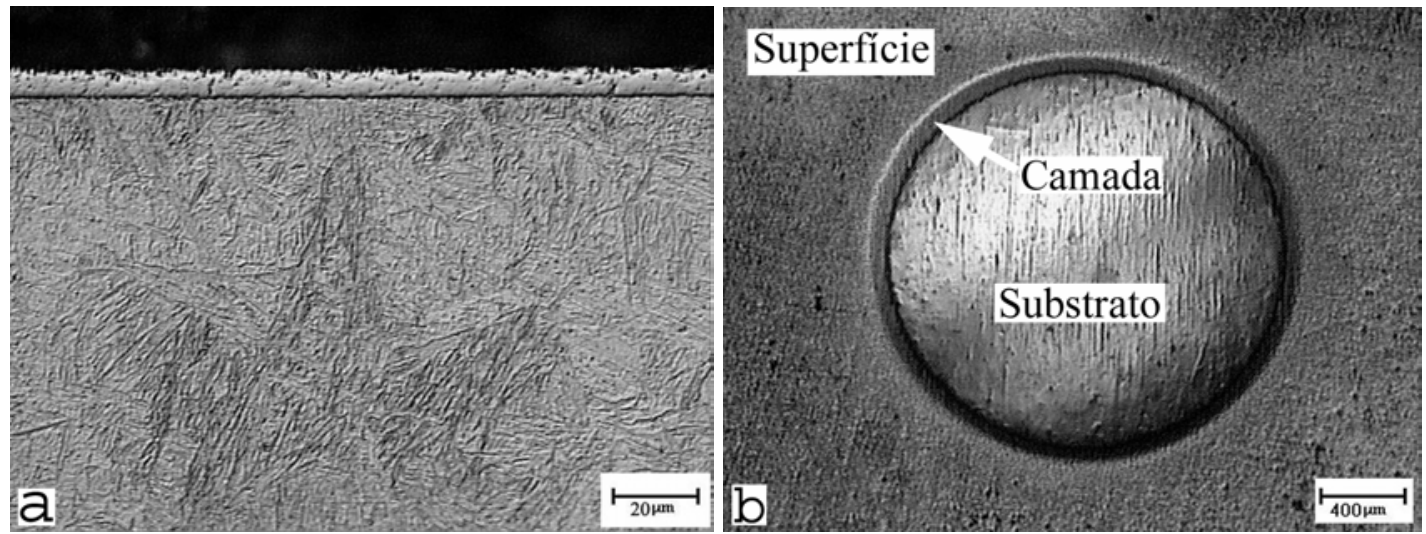

Figura 4.14 - Micrografias óticas do aço AISI H13 tratado em banho de bórax contendo $10 \% \mathrm{Fe}-\mathrm{V}+3 \% \mathrm{Al}$, à $1000^{\circ} \mathrm{C} / 4 \mathrm{~h}$ : (a) seção transversal. Camada de carboneto sobre a matriz martensítica. Ataque: Nital 3\%; (b) calota formada após ensaio de desgaste micro-abrasivo.

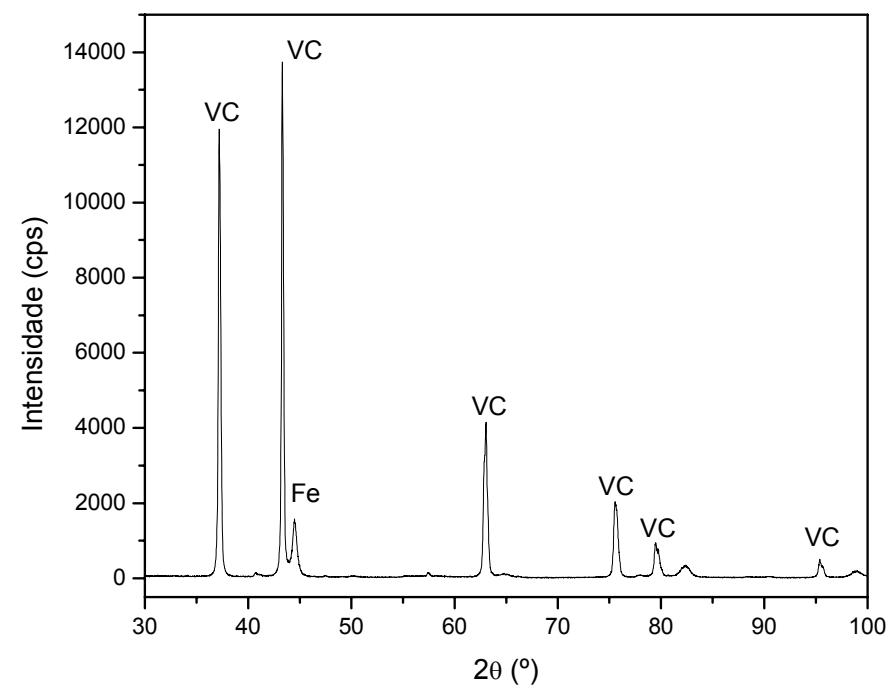

Figura 4.15 - Difratograma de raios-X da superfície do aço AISI H13 tratado em banho de bórax contendo $10 \% \mathrm{Fe}-\mathrm{V}+3 \% \mathrm{Al}$, à $1000^{\circ} \mathrm{C} / 4 \mathrm{~h}$. 

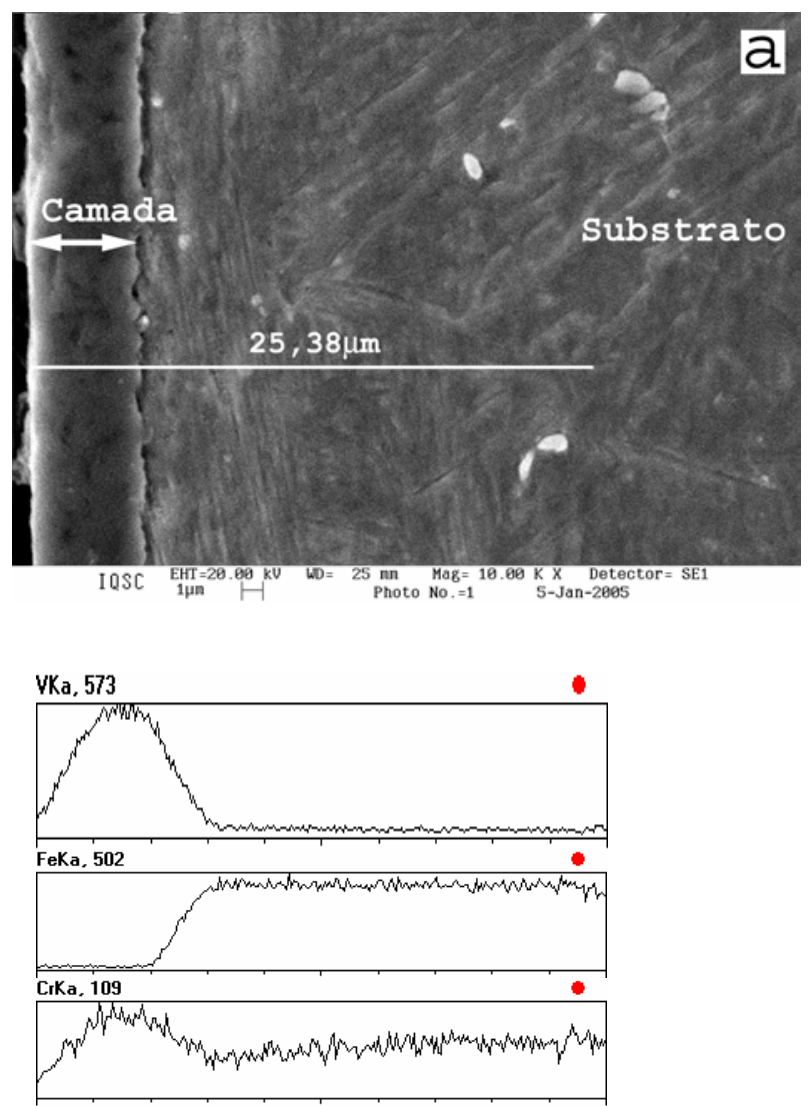

(b)

Figura 4.16 - Aço AISI H13 tratado em banho contendo 10\%Fe-V + 3\%Al: (a) Micrografia eletrônica mostrando a camada, a matriz, constituída de martensita, e a linha de varredura. Ataque: Reagente de Vilella; (b) Varredura em linha por EDS.

As micrografias óticas mostrando a camada formada no aço AISI D2 tratado no mesmo tipo de banho, nas mesmas condições, são apresentadas nas figuras 4.17a e 4.17b. Esta camada mediu $14,2 \mu \mathrm{m}$, sendo consideravelmente mais espessa do que a obtida no aço $\mathrm{H} 13$, conforme esperado.

O difratograma de raios- $X$ desta camada, na figura 4.18 , mostra que esta é constituída do mesmo tipo de carboneto (VC) obtido no aço AISI H13, com a presença de um pequeno pico relativo ao ferro. O vanádio, que é um forte formador de carboneto, difundiu através do banho em direção à superfície do substrato, onde se combinou quimicamente com o carbono, formando a camada de VC (Arai e Harper, 1991; Arai et al., 1987). O resultado da varredura em linha por EDS, mostrado na figura 4.19, indica que a camada é rica em vanádio. 

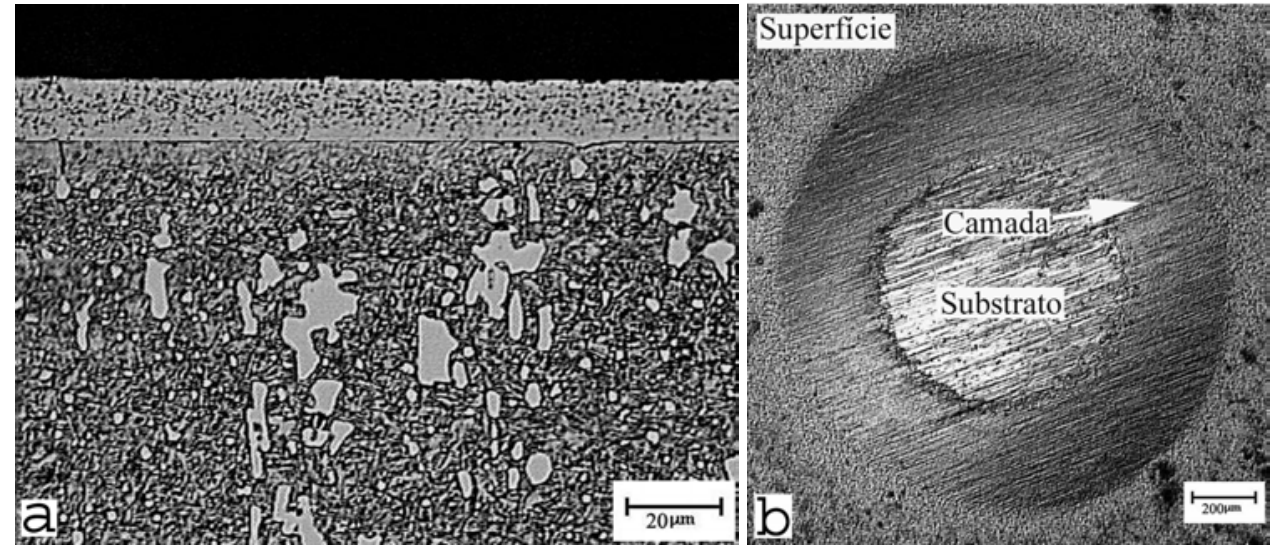

Figura 4.17 - Micrografias óticas do aço AISI D2 tratado em banho de borax contendo $10 \% \mathrm{Fe}-\mathrm{V}+3 \% \mathrm{Al}$, à $1000^{\circ} \mathrm{C} / 4 \mathrm{~h}$ : (a) seção transversal. Camada de carboneto sobre a matriz martensítica com carbonetos primários. Ataque: Reagente de Vilella; (b) calota formada após ensaio de desgaste micro-abrasivo.

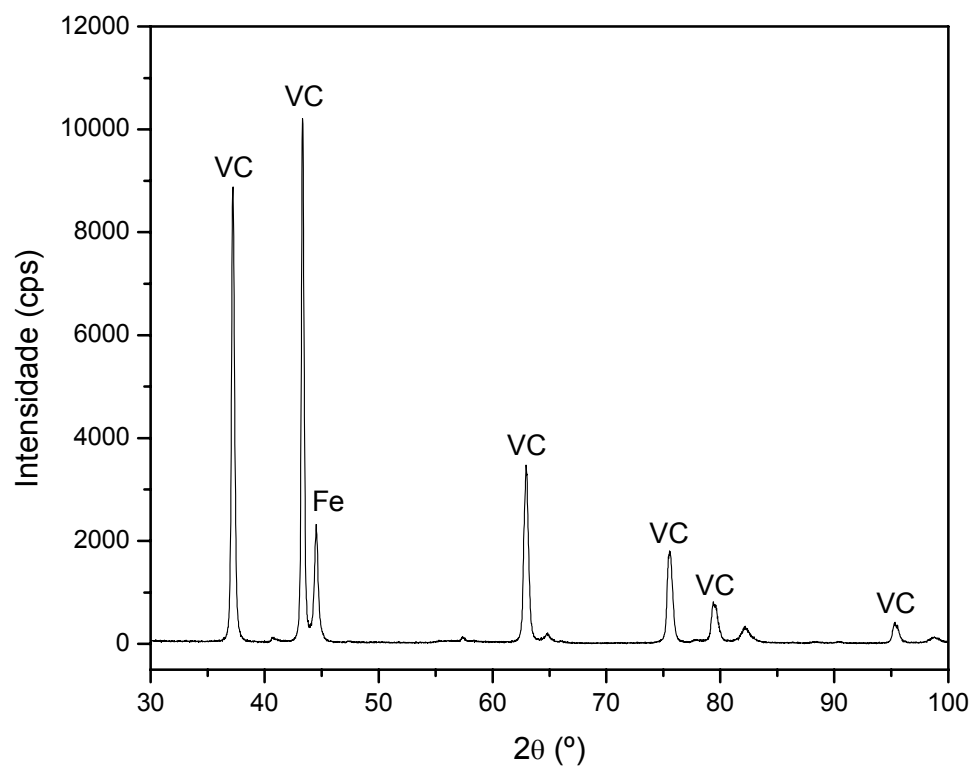

Figura 4.18 - Difratograma de raios-X da superfície do aço AISI D2 tratado em banho contendo $10 \% \mathrm{Fe}-\mathrm{V}+3 \% \mathrm{Al}$, à $1000^{\circ} \mathrm{C} / 4 \mathrm{~h}$. 

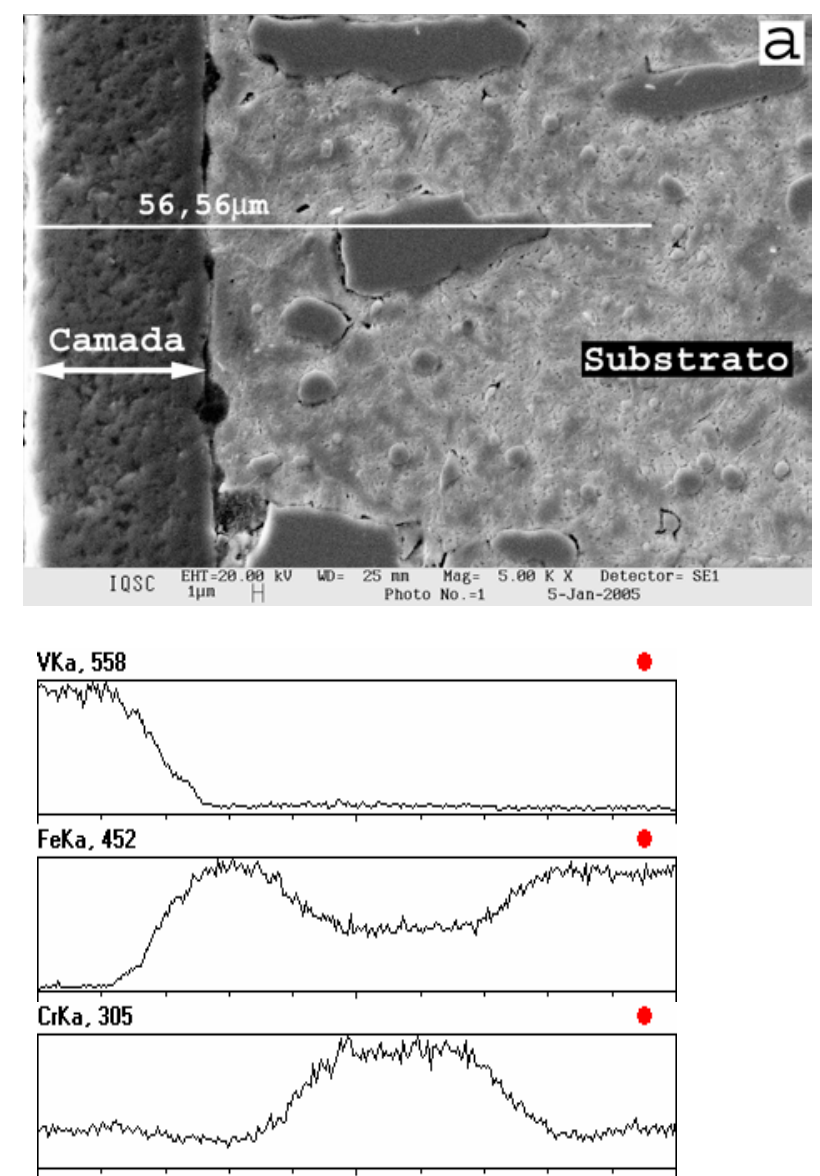

(b)

Figura 4.19 - Aço AISI D2 tratado em banho contendo 10\%Fe-V + 3\%Al: (a) Micrografia eletrônica mostrando a camada, a matriz, constituída de martensita e de carbonetos primários, e a linha de varredura. Ataque: Reagente de Vilella; (b) Varredura em linha por EDS.

Na tabela 4.6 são apresentados os valores de todas as espessuras das camadas de $\mathrm{NbC}$ e de VC obtidas nos aço AISI H13 e D2, determinados de duas formas: 1. Leitura direta no microdurômetro, com um micrômetro acoplado e, 2. calculada segundo a figura 3.5 e a Eq. (3.1) (Págs. 41 e 42, respectivamente), que utilizam o princípio do método de desgaste micro-abrasivo. Os resultados mostram que os valores obtidos das duas maneiras são coerentes, constatando a eficiência do método de medição por meio do ensaio de desgaste micro-abrasivo. 
Tabela 4.6 - Espessuras das camadas de $\mathrm{NbC}$ e de VC formadas aços AISI H13 e $\mathrm{D} 2$, à $1000^{\circ} \mathrm{C} / 4 \mathrm{~h}: e_{1}$ (medida no microdurômetro); $e_{2}$ (obtida segundo a equação 3.1).

\begin{tabular}{||c|c|c|c||}
\hline $\begin{array}{c}\text { Tipo da } \\
\text { camada }\end{array}$ & Substrato & $e_{1}(\mu \mathrm{m})$ & $\mathrm{e}_{2}(\mu \mathrm{m})$ \\
\hline \multirow{2}{*}{$\mathrm{NbC}$} & $\mathrm{H} 13$ & $6,2 \pm 1,0$ & 6,4 \\
\cline { 2 - 4 } & $\mathrm{D} 2$ & $15,6 \pm 1,2$ & 16,4 \\
\hline \multirow{2}{*}{$\mathrm{VC}$} & $\mathrm{H} 13$ & $5,8 \pm 1,0$ & 6,0 \\
\cline { 2 - 4 } & $\mathrm{D} 2$ & $14,2 \pm 1,0$ & 13,7 \\
\hline
\end{tabular}

\subsubsection{Tratamentos em banho de bórax contendo ferro-titânio/alumínio}

Nas amostras dos aços tratadas no banho contendo ferro-titânio, as camadas formadas apresentaram aspectos bastante diferentes daqueles das camadas de carbonetos obtidas nos banhos contendo ferro-nióbio ou ferro-vanádio. Na figura 4.20 têm-se micrografias da camada formada no aço AISI H13, tratado no banho de bórax contendo $10 \% \mathrm{Fe}-\mathrm{Ti}+5 \% \mathrm{Al}$. O difratograma de raios-X realizado na superfície da amostra tratada (Fig. 4.21), indica que a camada é constituída de boretos, principalmente pela fase $\mathrm{Fe}_{2} \mathrm{~B}$, e em menor escala pelas fases $\mathrm{FeB}$ e $\mathrm{CrB}$, o que está de acordo com a literatura (Sen et al., 2001). É provável que se tenha também a formação dos boretos mistos $(\mathrm{Fe}, \mathrm{Cr})_{2} \mathrm{~B}$ ou $(\mathrm{Fe}, \mathrm{Cr}) \mathrm{B}$, pois, como reportado por Chicco et al. (1998), o cromo tende a substituir o ferro na rede do $\mathrm{Fe}_{2} \mathrm{~B}$ da camada.

Nas micrografias óticas da seção transversal à superfície revestida da amostra, mostradas na figura 4.20, identificam-se quatro regiões distintas: 1. Uma camada superficial, a qual chamar-se-á de camada boretada; 2. Uma região sob a camada boretada, que é definida como subcamada "mole" (Chicco et al., 1998). 3. Uma zona de transição, caracterizada pela presença de partículas distribuídas na matriz (substrato), e 4. A matriz propriamente dita. A camada boretada apresenta 
neste caso, uma morfologia dentada, conhecida como "dente-de-serra" (Sinha, 1991; Chicco et al., 1998). De acordo com Selçuk et al. (2000), a morfologia do tipo "dente-de-serra" da camada de boreto de ferro é devido a uma pronunciada anisotropia do coeficiente de difusão do boro na rede tetragonal da fase $\mathrm{Fe}_{2} \mathrm{~B}$. $\mathrm{A}$ espessura média da camada boretada, medida conforme indicado na figura 3.3 (Pág. 45) foi de $70 \mu \mathrm{m}$. A região conhecida como sub-camada "mole" recebe esta nomenclatura por apresentar dureza inferior a do substrato (Sinha, 1991; Chicco et al., 1998). Este fenômeno é esperado em aços que apresentem teor de silício em torno de 1\%, em massa. A formação da sub-camada "mole", constituída de ferrita, é atribuída a ação do silício, que, por ser insolúvel na camada de boreto, é empurrado em direção ao substrato e se concentra na região da interface. Como o silício é um forte estabilizador da ferrita, ocorre a condição favorável para a formação dessa fase. A sub-camada mole é favorecida também pelo teor de carbono relativamente baixo do aço H13 (Sinha, 1991; Chicco et al., 1998).
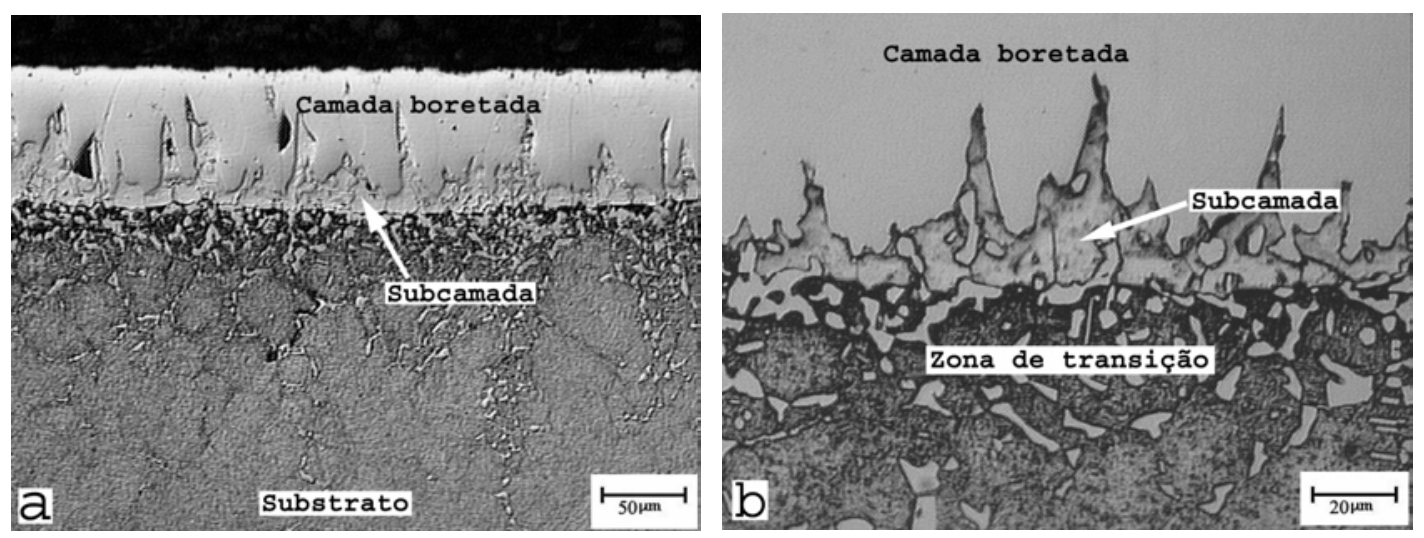

Figura 4.20 - (a) Micrografia ótica da camada formada no aço AISI H13, tratado em banho de bórax contendo $10 \% \mathrm{Fe}-\mathrm{Ti}+5 \% \mathrm{Al}, 1000^{\circ} \mathrm{C} / 4 \mathrm{~h}$; (b) Mesma amostra em aumento maior. Camadas de boretos sobre o substrato martensítico. Ataque: Nital $3 \%$. 


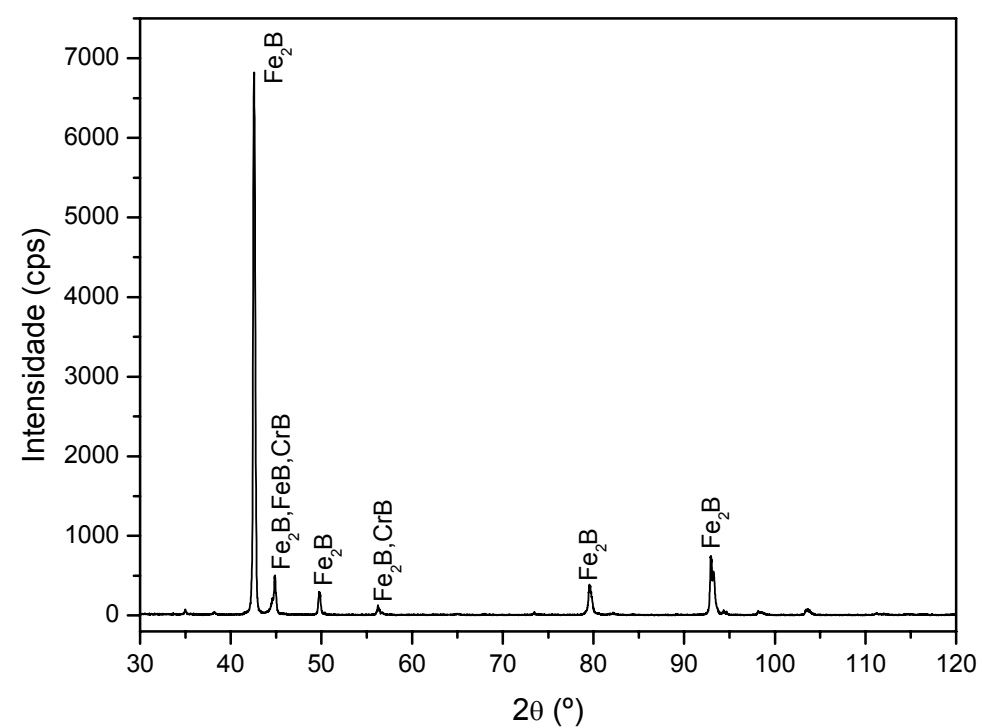

Figura 4.21 - Difratograma de raios-X do aço AISI H13 tratado em banho de bórax contendo $10 \% \mathrm{Fe}-\mathrm{Ti}+5 \% \mathrm{Al}, 1000^{\circ} \mathrm{C} / 4 \mathrm{~h}$.

No aço AISI D2 tratado no mesmo tipo de banho, a morfologia da camada é diferente da obtida no aço AISI H13. Não se observa a formação de uma subcamada "mole". Esse fato é atribuído ao teor de carbono mais elevado do aço AISI D2, considerando que o carbono é um estabilizador da austenita (Chicco et al., 1998) contrabalançando o efeito alfagênico do silício, permitindo assim, a obtenção de uma estrutura de têmpera. A camada apresenta uma interface irregular com o substrato. Sua espessura média foi de $60 \mu \mathrm{m}$. A menor espessura neste caso, em relação a espessura obtida no aço AISI H13, deveu-se provavelmente a presença do cromo, que dificulta a difusão do boro (Sinha, 1991). O difratograma de raios-X (figura 4.23) mostra que a camada obtida no aço AISI D2 também é constituída predominantemente de $\mathrm{Fe}_{2} \mathrm{~B}$, sendo observados ainda, picos relativos a outros tipos de boretos de ferro (FeB e $\left.\mathrm{Fe}_{3} \mathrm{~B}\right)$ e de cromo $\left(\mathrm{CrB}\right.$ e $\left.\mathrm{Cr}_{2} \mathrm{~B}_{3}\right)$. Observa-se que a quantidade de boretos de cromo é maior do que no caso do aço AISI H13, o que se explica pelo teor de cromo mais elevado do aço AISI D2. 


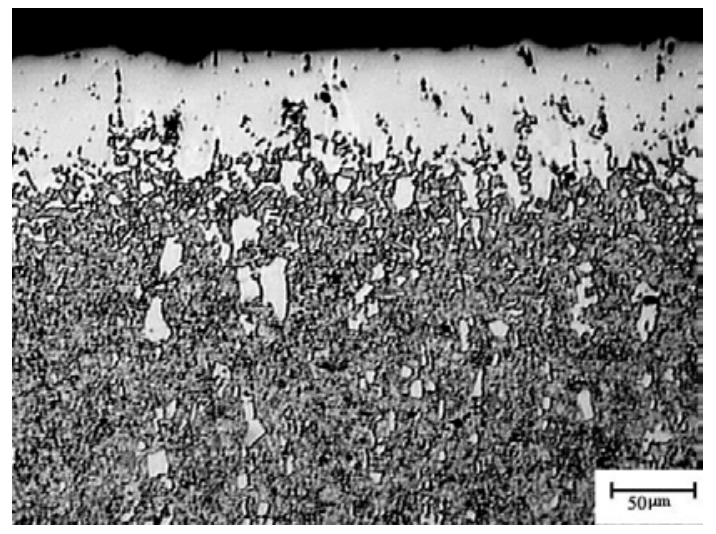

Figura 4.22 - Micrografia ótica mostrando a camada formada sobre o aço AISI D2, tratado no banho $10 \% \mathrm{Fe}-\mathrm{Ti}+5 \% \mathrm{Al}, 1000^{\circ} \mathrm{C} / 4 \mathrm{~h}$. Camada de boretos sobre o substrato martensítico. Ataque: Reagente de Vilella.

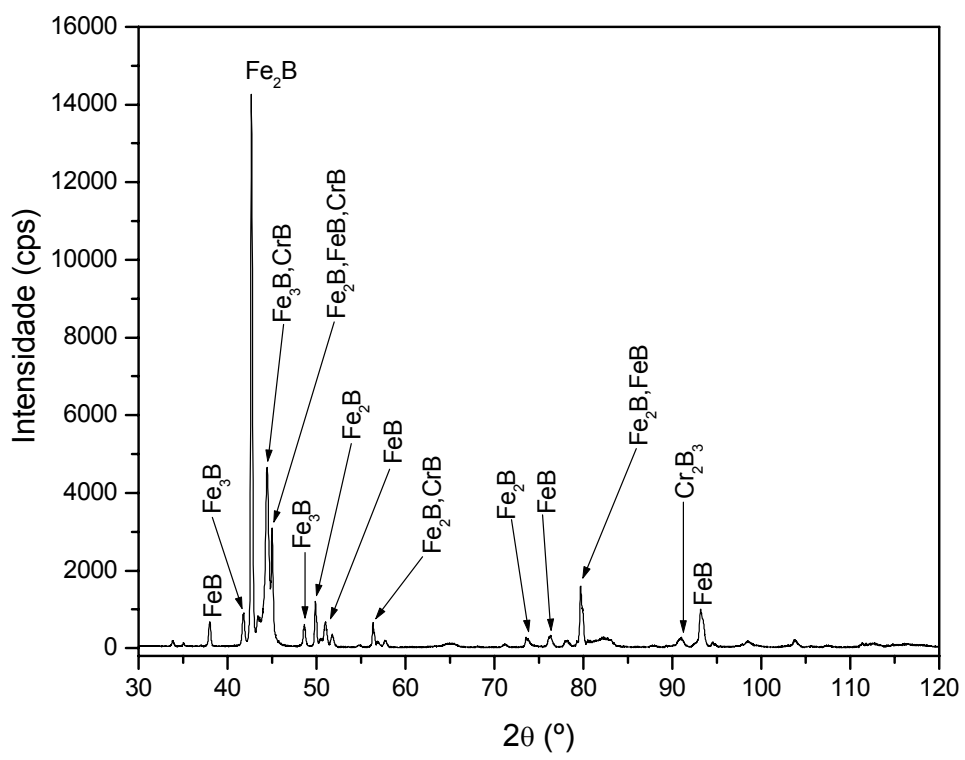

Figura 4.23 - Difratograma de raios-X do aço AISI D2 tratado em banho de bórax contendo $10 \% \mathrm{Fe}-\mathrm{Ti}+5 \% \mathrm{Al}, 1000^{\circ} \mathrm{C} / 4 \mathrm{~h}$.

A obtenção de camadas de boretos nos aços AISI H13 e D2 tratados nos banhos de bórax com adição de $10 \% \mathrm{Fe}-\mathrm{Ti}+5 \% \mathrm{Al}$ ocorreu, provavelmente, devido a redução química do bórax, com a conseqüente liberação de átomos de boro para se combinarem quimicamente com os elementos dos substratos. Embora o titânio apresente uma energia livre de formação de carboneto relativamente baixa, sua 
energia livre de formação de óxido é inferior a do $\mathrm{B}_{2} \mathrm{O}_{3}$ (Arai et al., 1987). Segundo Arai (1979), em um banho de bórax contendo Fe-Ti, pode ocorrer a formação de carboneto e/ou boreto na superfície de um aço.

\subsubsection{Tratamentos em banho de bórax contendo ferro-titânio/ferro- nióbio/alumínio}

Os aços AISI D2 e AISI H13 foram tratados em banho de bórax contendo $10 \% \mathrm{Fe}-\mathrm{Ti}+5 \% \mathrm{Fe}-\mathrm{Nb}+3 \% \mathrm{Al}$. Na figura 4.24 são apresentadas as micrografias eletrônicas destas amostras tratadas a $1000^{\circ} \mathrm{C}$, durante $4 \mathrm{~h}$. As camadas obtidas são homogêneas, com grande regularidade em suas espessuras e interfaces planas com os substratos.

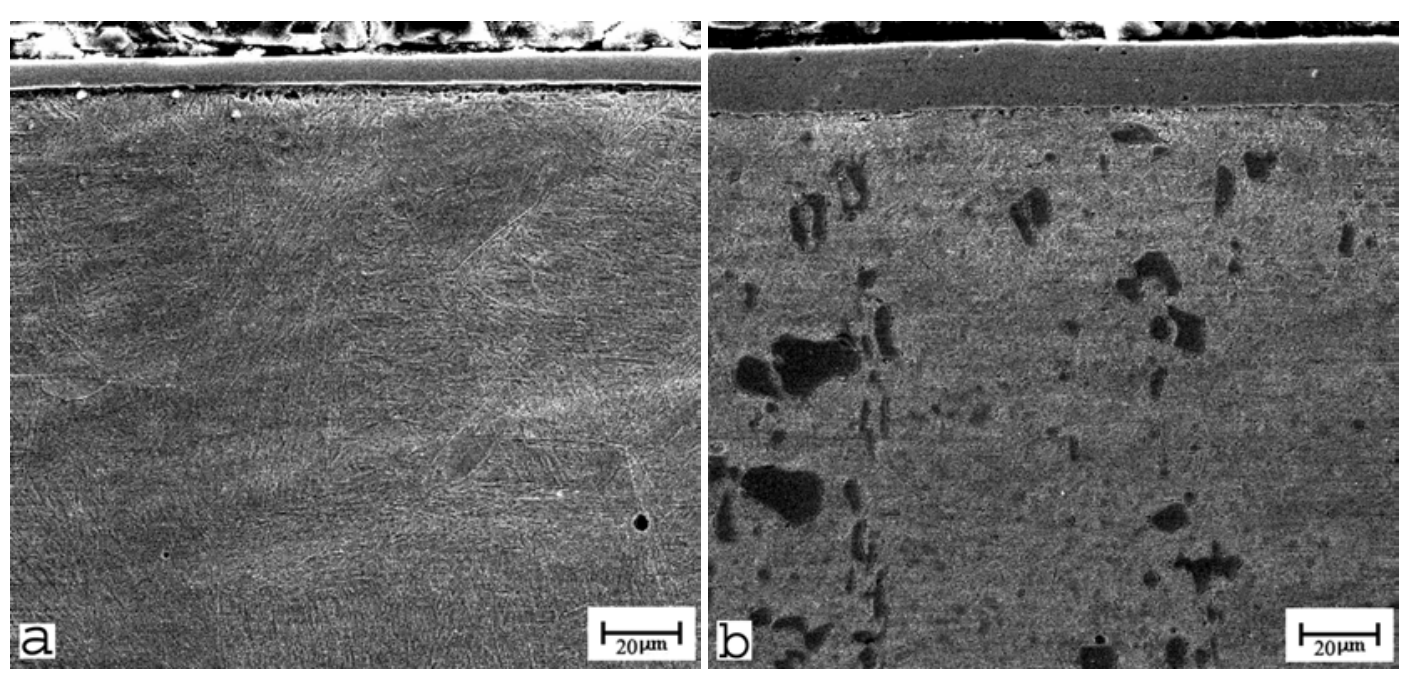

Figura 4.24 - MEV das amostras tratadas em banho de borax contendo $10 \% \mathrm{Fe}-\mathrm{Ti}+$ $5 \% \mathrm{Fe}-\mathrm{Nb}+3 \% \mathrm{Al}$, a $1000^{\circ} \mathrm{C} / 4 \mathrm{~h}$ : (a) Camada de carboneto sobre uma matriz martensítica do aço AISI H13; (b) Camada de carboneto sobre uma matriz martensítica com carbonetos primários do aço AISI D2. Ataque: Reagente de Vilella.

Nos difratogramas de raios-X das camadas, apresentados na figura 4.25 , verifica-se que para os dois aços não se formaram carbonetos complexos, nem boretos, sendo as camadas constituídas unicamente de $\mathrm{NbC}$. Este é o mesmo 
constituinte da camada obtida nos tratamentos realizados no banho contendo apenas ferro-nióbio e alumínio. As camadas foram formadas pela reação química do nióbio dissolvido no banho com o carbono no substrato. Provavelmente o titânio dissolvido no banho reagiu com o bórax, e quando as amostras foram imersas, não havia titânio livre em quantidade suficiente para formar o carboneto TiC em suas superfícies. As camadas de $\mathrm{NbC}$ obtidas nos aços AISI H13 e D2 apresentaram espessuras de 6,8 e 16,7 $\mu \mathrm{m}$, e durezas de 2357,0 e $2367,2 \mathrm{HV}$, respectivamente.
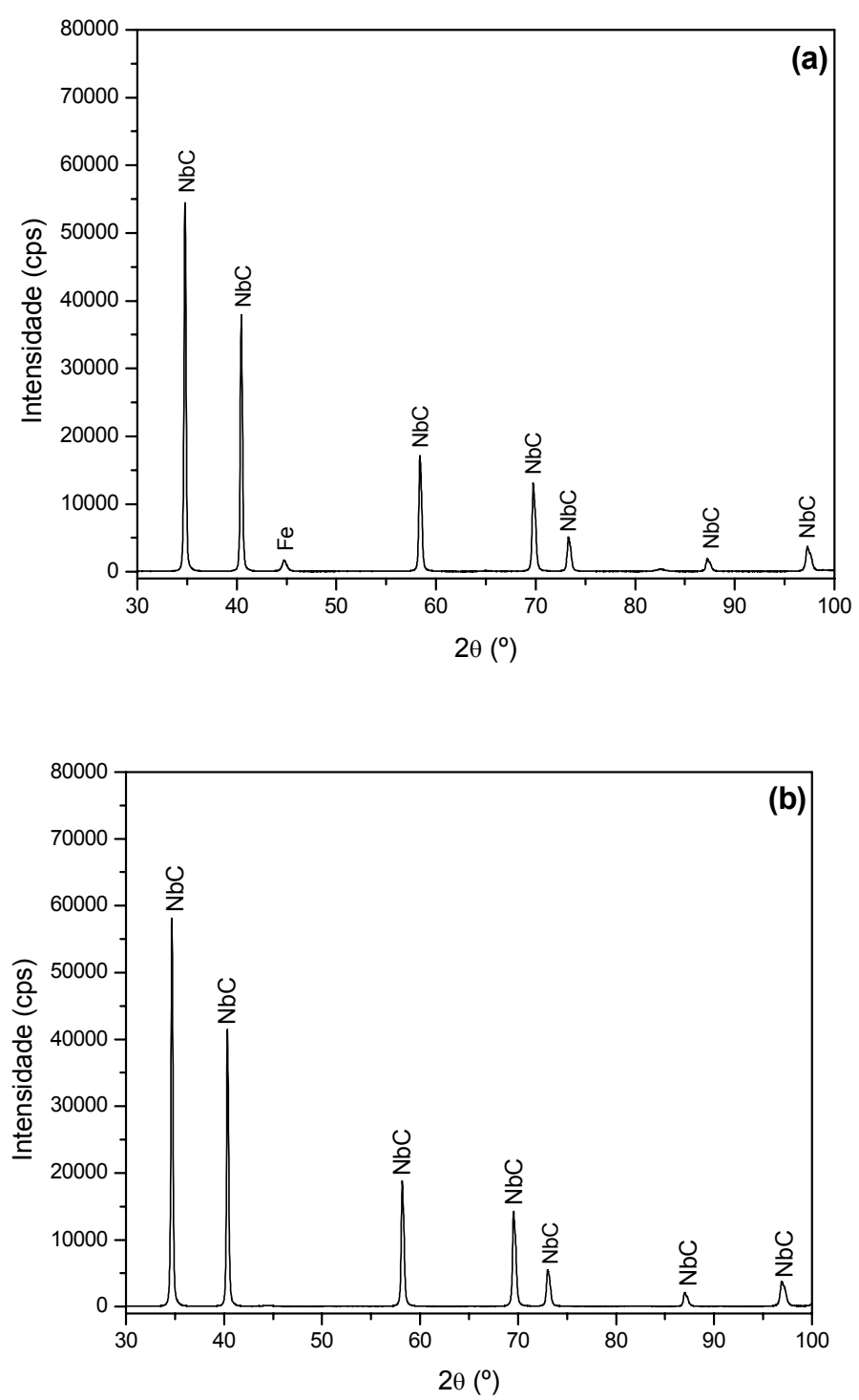

Figura 4.25 - Difratograma de raios- $X$ das superfícies dos aços tratados em banho de borax contendo $10 \% \mathrm{Fe}-\mathrm{Ti}+5 \% \mathrm{Fe}-\mathrm{Nb}+3 \% \mathrm{Al}$, a $1000^{\circ} \mathrm{C} / 4 \mathrm{~h}$ : (a) AISI H13 e (b) AISI D2. 


\subsubsection{Tratamentos em banho de bórax contendo apenas alumínio}

Foram realizados tratamentos dos aços AISI H13 e AISI D2 em banhos de bórax contendo apenas alumínio. Nesse caso, o bórax deixou de ser apenas um veículo, onde os elementos formadores da camada são dissolvidos, como ocorreu nos banhos adicionados de Fe-Nb e Fe-V, e passa a ser um agente ativo do processo, na medida em que a camada é formada pela combinação do ferro presente no substrato com o boro disponibilizado pela redução química do bórax, devido a ação do alumínio. Ocorre a formação de camadas de boretos.

\subsubsection{Boretação do aço AISI H13}

O aço AISI H13 foi tratado em banhos com teores de alumínio de 5, 10 e $15 \%$, a $1000^{\circ} \mathrm{C}$, durante $4 \mathrm{~h}$. As micrografias óticas, e as análises de raios- $\mathrm{X}$ das amostras tratadas são mostradas nas figuras 4.26 a 4.30 . Para o banho contendo 5\%Al não houve formação de camada (Fig. 4.26). Provavelmente a quantidade de alumínio não foi suficiente para reduzir o bórax a um nível adequado à boretação. Para teores de Al mais elevados ocorreu a formação de camadas. No banho contendo 10\%Al (Fig. 4.27) formou-se uma camada boretada com espessura média de $105 \mu \mathrm{m}$. A morfologia da camada apresentou o aspecto do tipo "dente-de-serra" na interface com a subcamada "mole" (indicada pela seta na Fig. 4.27a), a qual teve uma espessura média de $25 \mu \mathrm{m}$. Na amostra tratada no banho contendo $15 \% \mathrm{Al}$ (Fig. 4.29), a camada boretada apresentou morfologia semelhante e com uma espessura maior, a qual mediu $130 \mu \mathrm{m}$. Neste caso, a espessura média da subcamada foi de $30 \mu \mathrm{m}$. O banho contendo um teor de alumínio mais elevado tem um potencial de boretação maior, devido à maior redução química do bórax. Isso explica a obtenção de uma camada mais espessa quando se utilizou o banho contendo 15\%Al. Por meio de análises de raios-X (Figs. 4.28 e 4.30), identificou-se que as camadas são constituídas pelas fases $\mathrm{Fe}_{2} \mathrm{~B}$, $\mathrm{FeB}, \mathrm{CrB}$ e $\mathrm{Cr}_{2} \mathrm{~B}_{3}$, sendo $\mathrm{Fe}_{2} \mathrm{~B}$ 
a fase predominante, o que é desejável, uma vez que apresenta maior tenacidade (Sen e Sen, 2003). Observa-se que a quantidade de picos relativos à fase FeB é maior no caso da camada obtida no banho contendo 15\%Al. A formação da fase FeB é favorecida pelo maior potencial de boretação do banho (Selçuk et al., 2000).

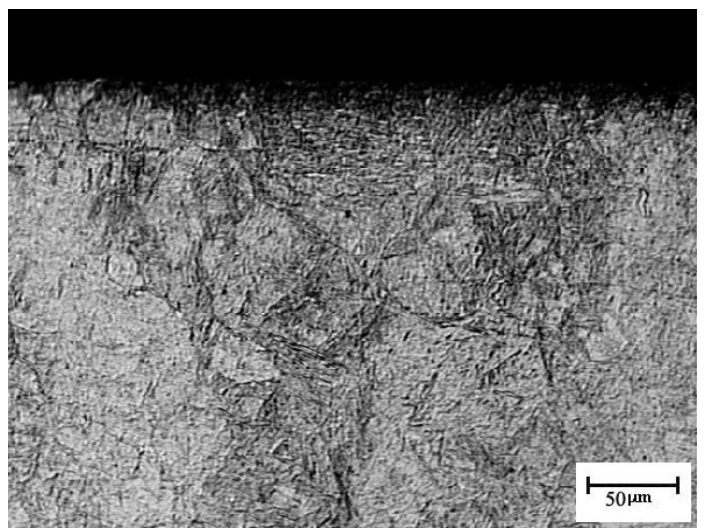

Figura 4.26 - Micrografia ótica do aço AISI H13 tratado em banho de bórax contendo $5 \% \mathrm{Al}, 1000^{\circ} \mathrm{C} / 4 \mathrm{~h}$. Não se formou camada. Ataque: Nital $3 \%$.
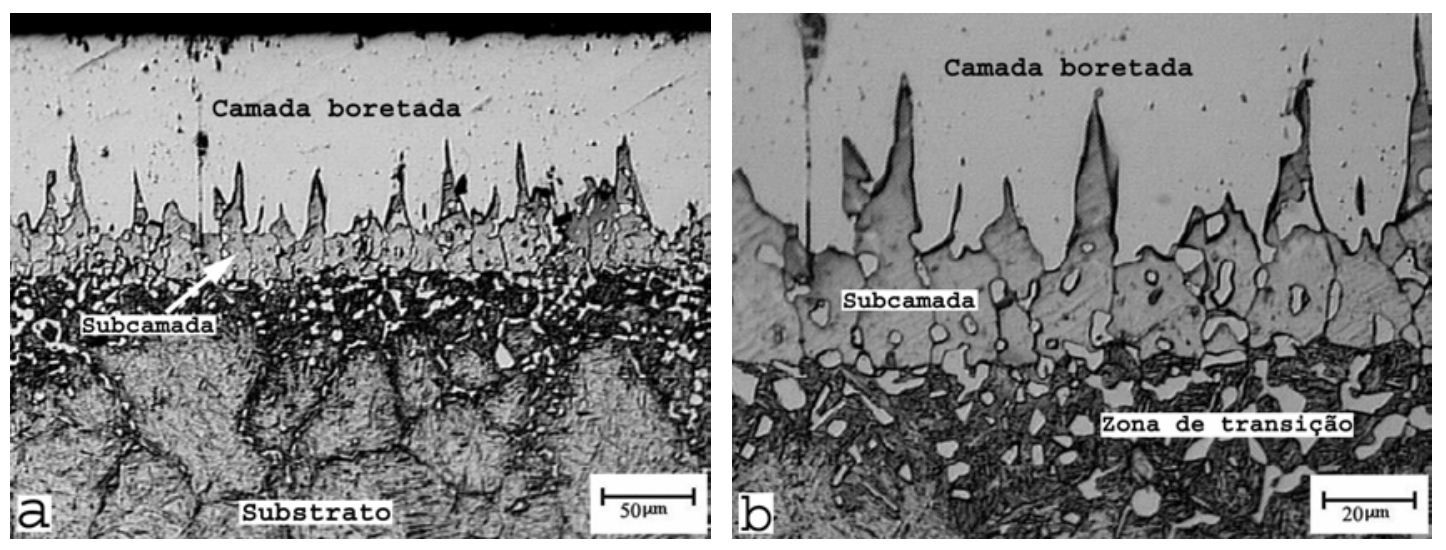

Figura 4.27 - (a) Micrografia ótica do aço AISI H13 tratado em banho de bórax contendo $10 \% \mathrm{Al}, 1000^{\circ} \mathrm{C} / 4 \mathrm{~h}$; (b) Mesma amostra, em aumento maior. Camada de boretos obtida sobre o substrato martensítico. Ataque: Nital $3 \%$. 


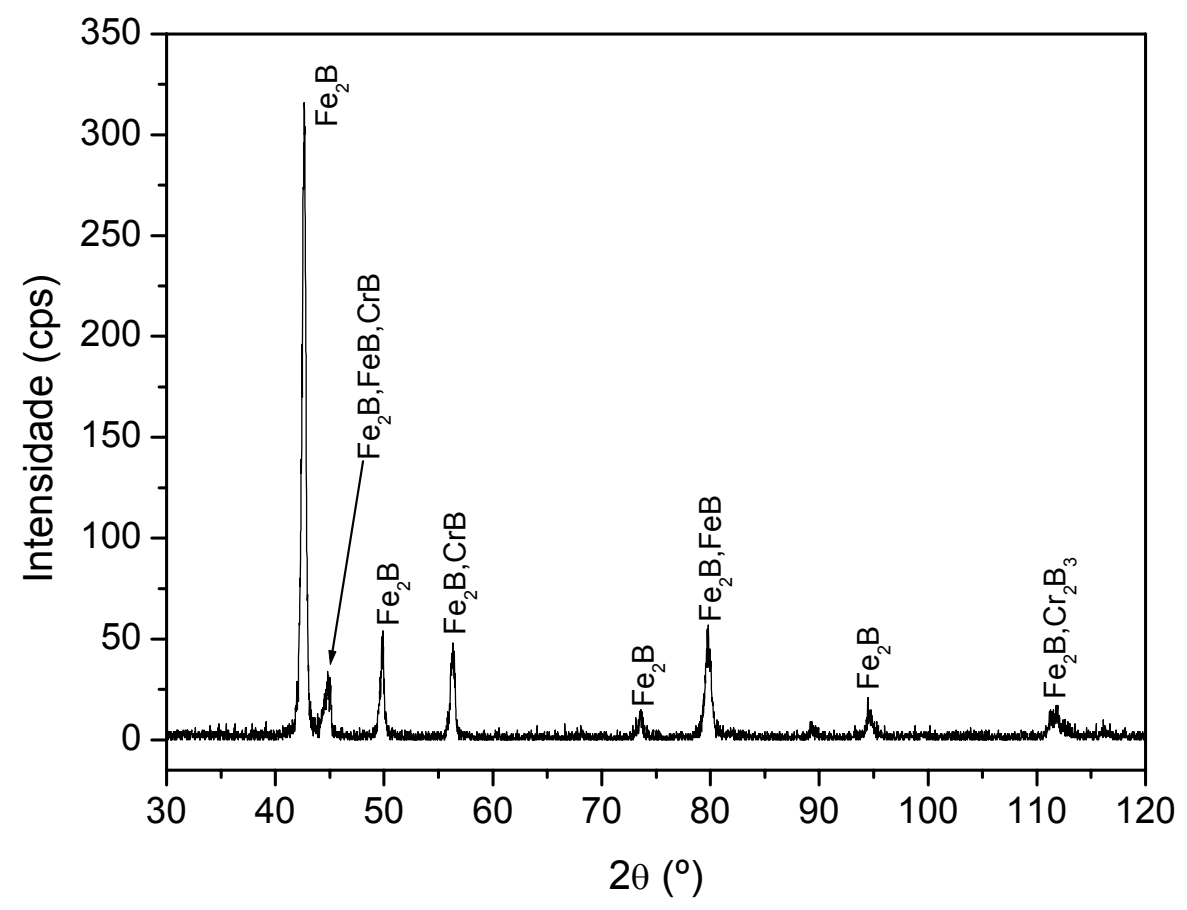

Figura 4.28 - Difratograma de raios-X do aço AISI H13 tratado no banho de bórax contendo $10 \% \mathrm{Al}, 1000^{\circ} \mathrm{C} / 4 \mathrm{~h}$.
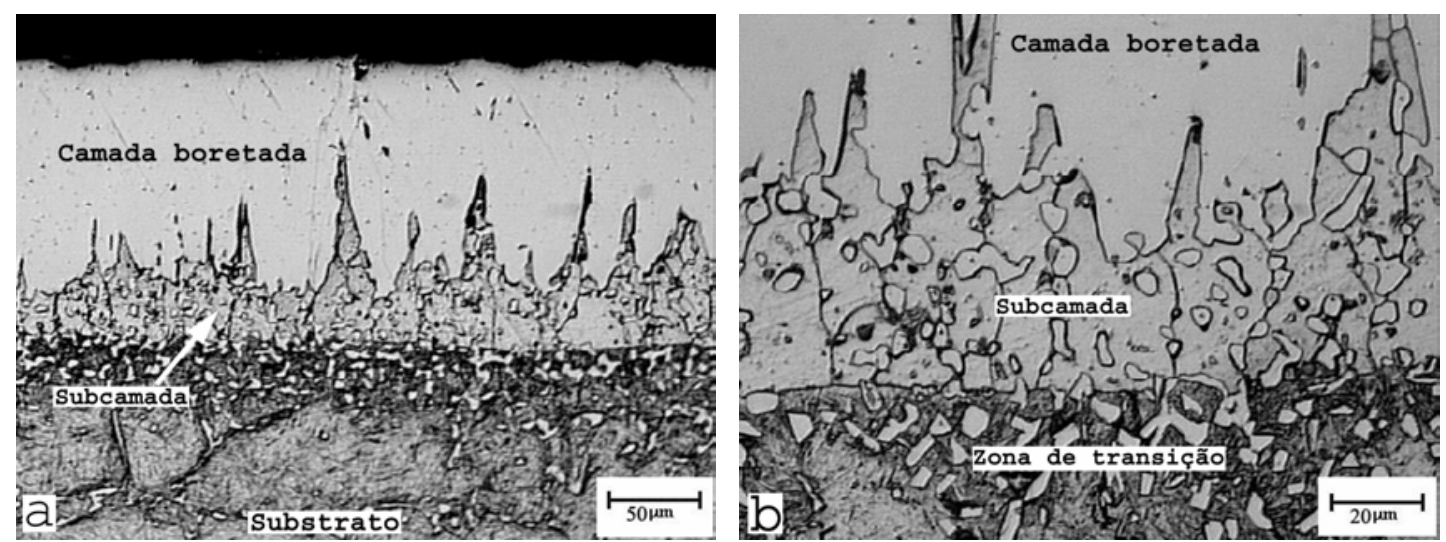

Figura 4.29 - (a) Micrografia ótica do aço AISI H13 tratado em banho de bórax contendo $15 \% \mathrm{Al}, 1000^{\circ} \mathrm{C} / 4 \mathrm{~h}$; (b) Mesma amostra, em aumento maior. Camada de boretos obtida sobre o substrato martensítico. Ataque: Nital 3\%. 


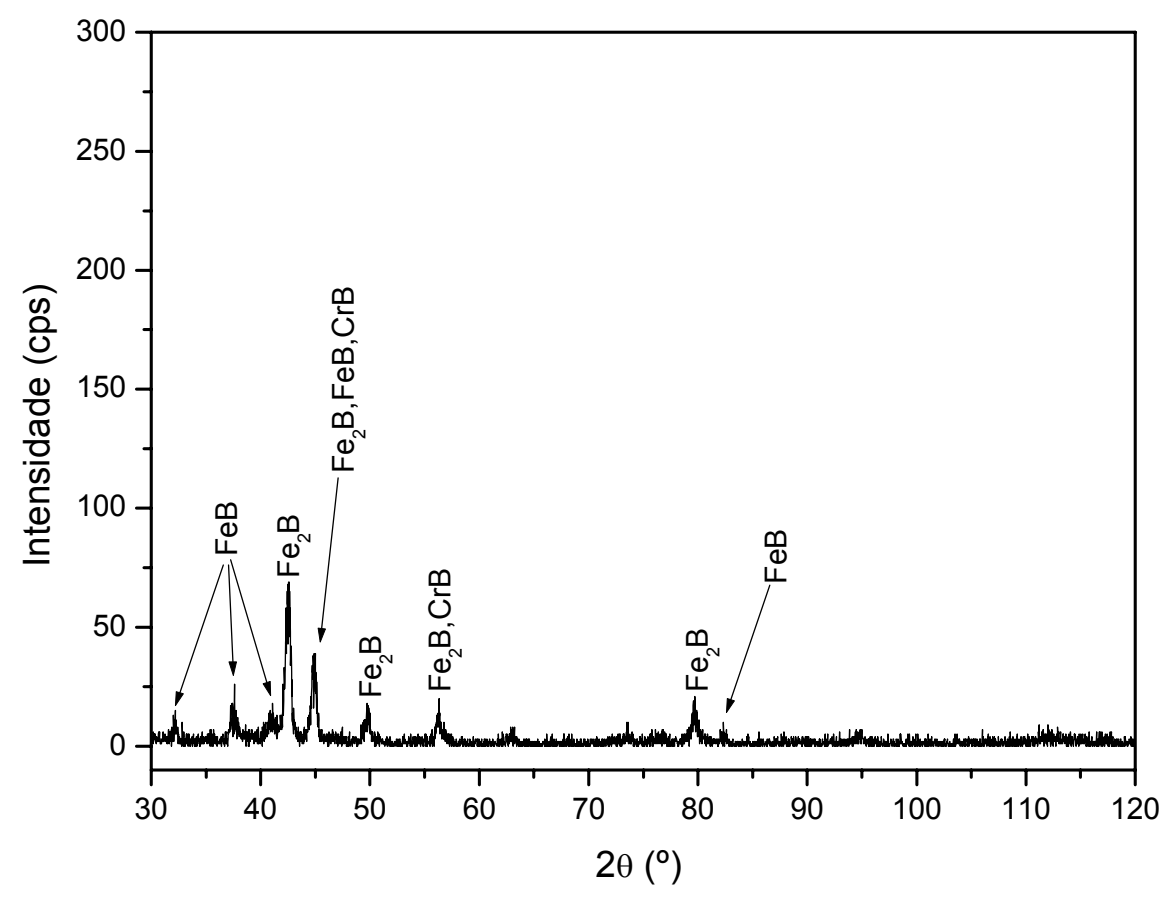

Figura 4.30 - Difratograma de raios-X do aço AISI H13 tratado em banho de bórax com $15 \% \mathrm{Al}, 1000^{\circ} \mathrm{C} / 4 \mathrm{~h}$.

\subsubsection{Boretação do aço AISI D2}

O aço AISI D2 foi tratado em banhos de bórax contendo 10 e $15 \%$ de alumínio. Para a composição de banho de $10 \% \mathrm{Al}$, o aço foi tratado à $1000^{\circ} \mathrm{C}$, enquanto que para o banho contendo $15 \% \mathrm{Al}$, realizaram-se tratamentos à $800 \mathrm{e}$ $1000^{\circ} \mathrm{C}$, para se verificar o efeito da temperatura de tratamento. As micrografias óticas e os difratogramas de raios- $\mathrm{X}$ das amostras tratadas à $1000^{\circ} \mathrm{C} / 4 \mathrm{~h}$ são mostradas nas figuras 4.31 a 4.34 .

Nas micrografias das amostras do aço AISI D2 boretadas, mostradas nas figuras $4.31,4.33$ e 4.35 , não se observa a formação da subcamada, de maneira que três regiões distintas são identificadas: 1. A camada boretada; 2. Uma zona intermediária entre a camada e o substrato; 3 . O substrato. 


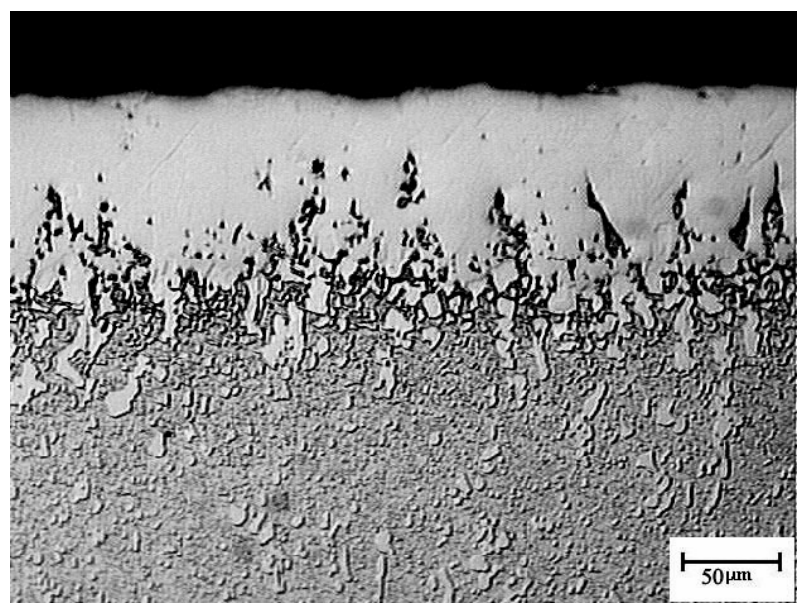

Figura 4.31 - Micrografia ótica do aço AISI D2 tratado em banho de bórax contendo $10 \% \mathrm{Al}, 1000^{\circ} \mathrm{C} / 4 \mathrm{~h}$. Camada de boretos sobre o substrato martensítico com carbonetos primários. Ataque: Reagente de Vilella.

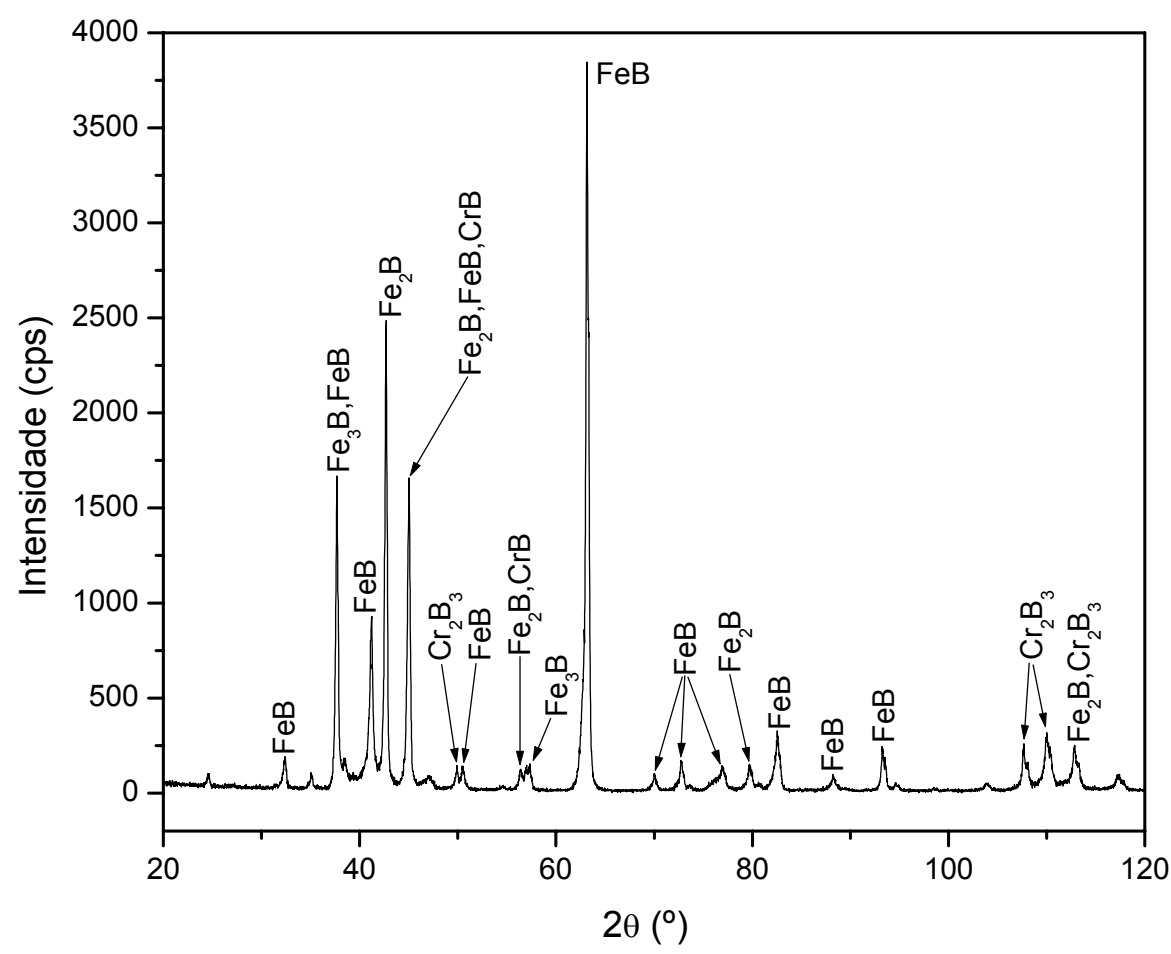

Figura 4.32 - Difratograma de raios-X do aço AISI D2 tratado em banho de bórax contendo $10 \% \mathrm{Al}, 1000^{\circ} \mathrm{C} / 4 \mathrm{~h}$. 


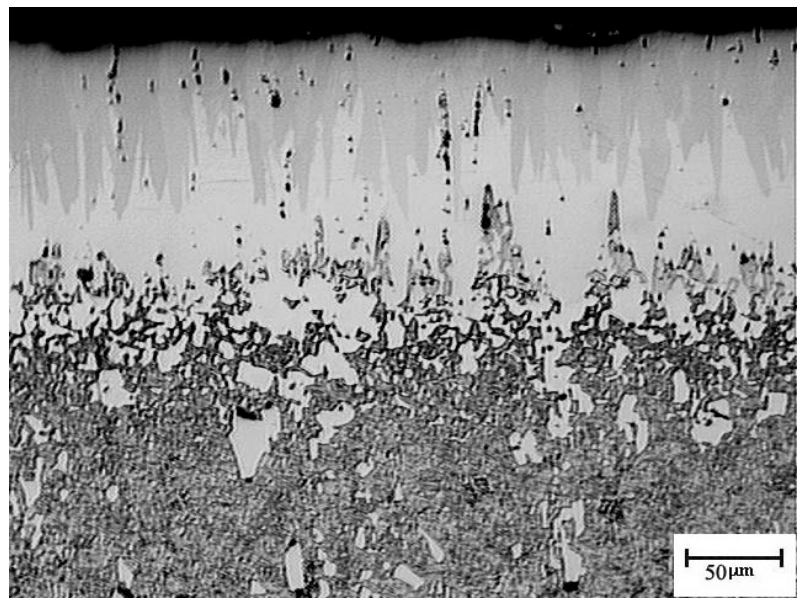

Figura 4.33 - Micrografia ótica do aço AISI D2 tratado em banho de bórax contendo $15 \% \mathrm{Al}, 1000^{\circ} \mathrm{C} / 4 \mathrm{~h}$. Camada de boretos sobre o substrato martensítico com carbonetos primários. Ataque: Reagente de Vilella.

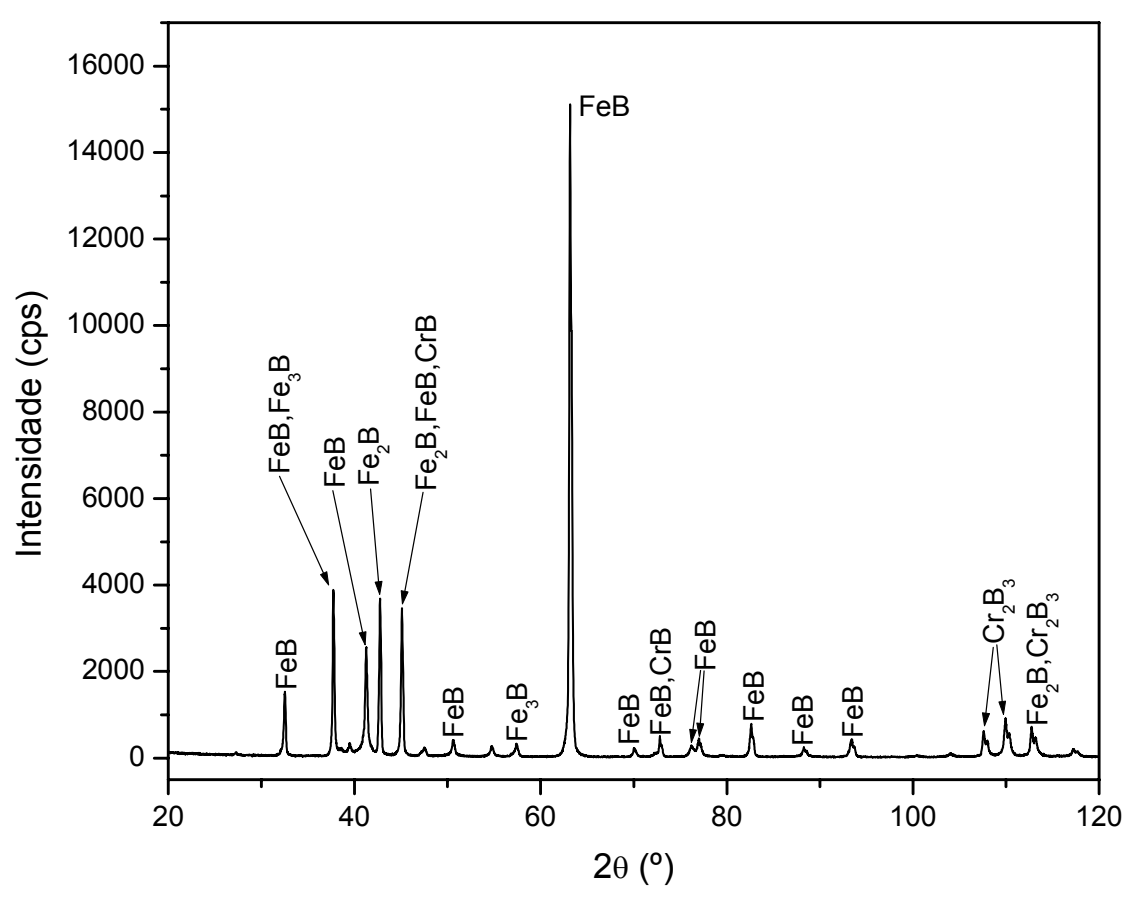

Figura 4.34 - Difratograma de raios-X do aço AISI D2 tratado em banho de bórax contendo $15 \% \mathrm{Al}, 1000^{\circ} \mathrm{C} / 4 \mathrm{~h}$.

A amostra tratada no banho contendo 10\%Al (Fig. 4.31) apresentou uma camada de boretos com espessura média de $90 \mu \mathrm{m}$, enquanto na amostra tratada no banho contendo 15\%Al (Fig. 4.33), a espessura da camada foi de $125 \mu \mathrm{m}$. O teor 
de cromo mais elevado do aço AISI D2 foi provavelmente o responsável pela menor espessura da camada, em comparação com a formada no aço AISI H13, uma vez que, segundo Sinha (1991), elementos de liga restringem a difusão do boro e retardam o crescimento da camada de boreto, devido à formação de uma barreira de difusão. Os difratogramas de raios-X do aço AISI D2 tratados nos banhos contendo 10 e 15\%Al, são mostrados nas figuras 4.32 e 4.34, respectivamente. Nos dois casos foram identificados boretos de ferro $\left(\mathrm{FeB}, \mathrm{Fe}_{2} \mathrm{~B}, \mathrm{Fe}_{3} \mathrm{~B}\right)$ e de cromo $(\mathrm{CrB}$, $\mathrm{Cr}_{2} \mathrm{~B}_{3}$ ), com predominância da fase FeB. A formação da fase $\mathrm{FeB}$ é favorecida pela presença de elementos de liga em teores elevados (Selçuk et al., 2000). Comparando-se as figuras 4.32 e 4.34 observa-se que o pico relativo à fase $\mathrm{Fe}_{2} \mathrm{~B}$ aparece com maior intensidade na amostra tratada no banho contendo um teor de alumínio menor, ou seja, quando se tem um menor potencial de boretação.

No tratamento do aço AISI D2 realizado à $800^{\circ} \mathrm{C} / 4 \mathrm{~h}$, no banho contendo 15\%Al (Fig. 4.35), a espessura da camada foi consideravelmente menor, medindo aproximadamente $30 \mu \mathrm{m}$, pelo fato da boretação ser um processo termicamente ativado (Sinha, 1991). Na figura 4.36 apresenta-se o difratograma de raios- $X$ dessa amostra. As fases identificadas foram $\mathrm{FeB}, \mathrm{Fe}_{2} \mathrm{~B}, \mathrm{Fe}_{3} \mathrm{~B}, \mathrm{CrB}$ e $\mathrm{Cr}_{2} \mathrm{~B}_{3}$, sendo o pico de maior intensidade aquele correspondente à fase FeB.

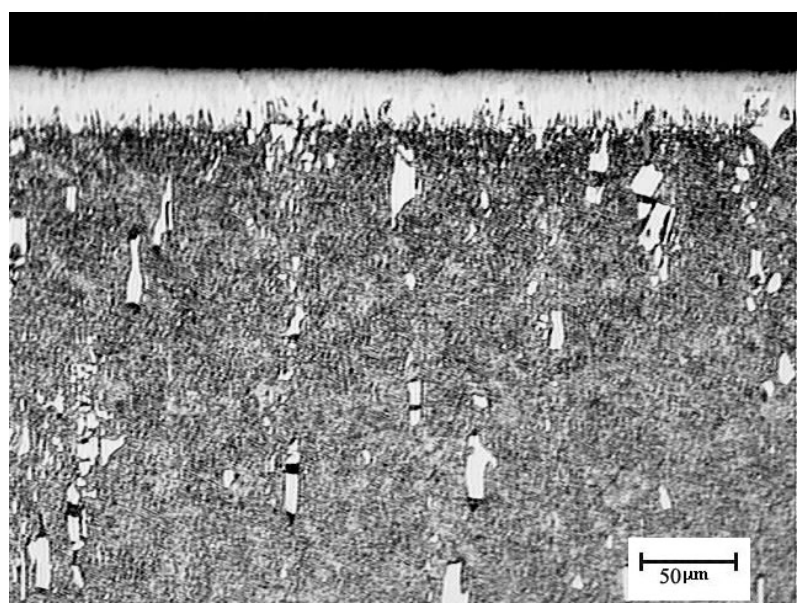

Figura 4.35 - Micrografia ótica do aço AISI D2 tratado em banho de bórax contendo $15 \% \mathrm{Al}, 800^{\circ} \mathrm{C} / 4 \mathrm{~h}$. Camada de boretos sobre o substrato martensítico com carbonetos primáros. Ataque: Reagente de Vilella. 


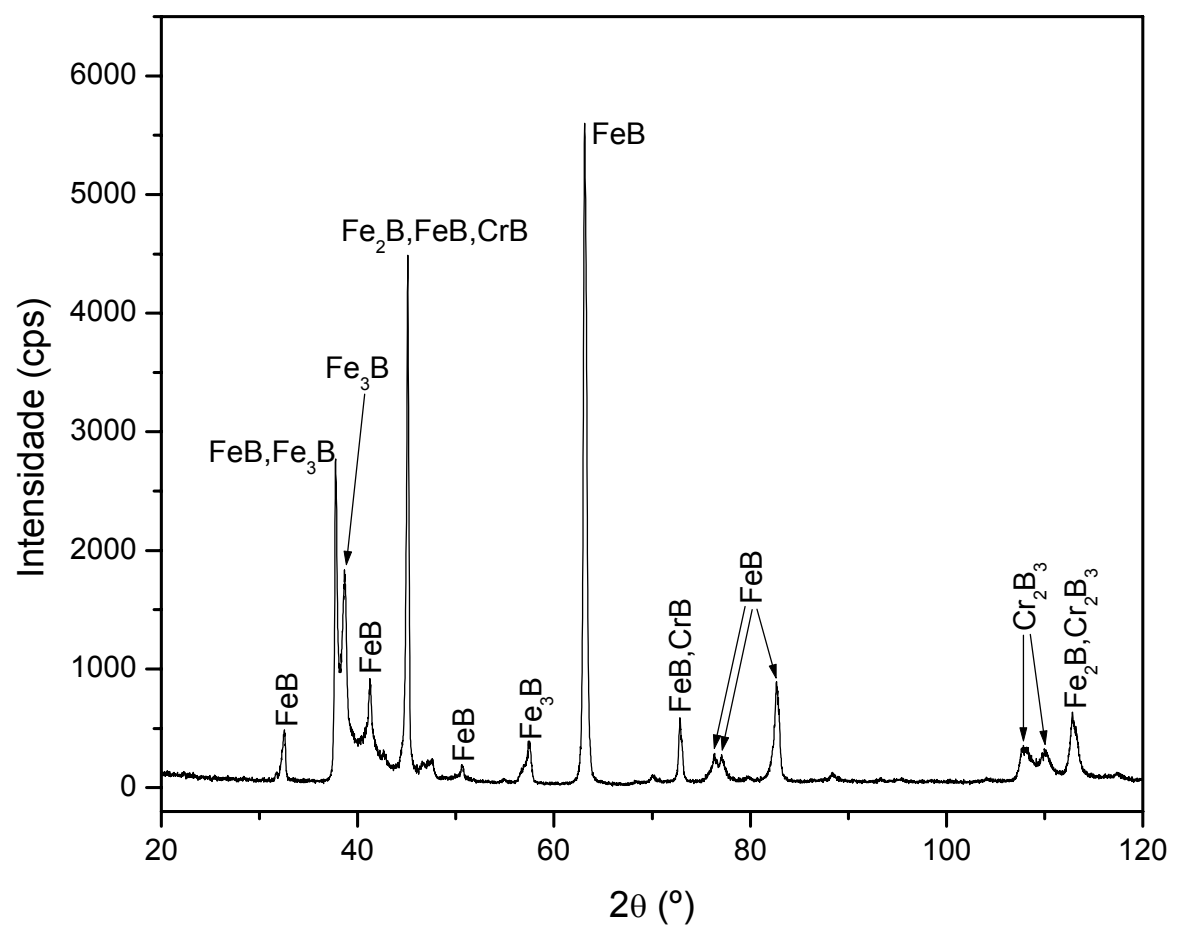

Figura 4.36 - Difratograma de raios-X do aço AISI D2 tratado em banho de bórax contendo $15 \% \mathrm{Al}, 800^{\circ} \mathrm{C} / 4 \mathrm{~h}$.

\subsubsection{Análises químicas pontuais por meio de MEV/EDS das camadas de} boretos produzidas nos aços AISI H13 e D2

As camadas de boretos obtidas nos aços AISI H13 e D2 foram analisadas por MEV/EDS. Realizaram-se análises pontuais para determinar as concentrações de Si, V, Cr e Mo ao longo das seções transversais dessas camadas.

\subsubsection{Análises químicas pontuais das camadas boretadas produzidas no} aço AISI H13

Nas figuras 4.37 e 4.38 apresentam-se, respectivamente, as micrografias eletrônicas e os perfis de concentração de Si, V, Cr e Mo, a partir da superfície em direção ao substrato, para o aço AISI H13 boretado no banho contendo $10 \% \mathrm{Fe}-\mathrm{Ti}+$ 
5\%Al. Os pontos de 1-5 foram analisados por EDS. Na figura 4.39 apresentam-se as micrografias eletrônicas do aço $\mathrm{H} 13$ tratado no banho contendo $15 \% \mathrm{Al}$, indicando os pontos analisados por EDS, cujos resultados são mostrados na figura 4.40 .
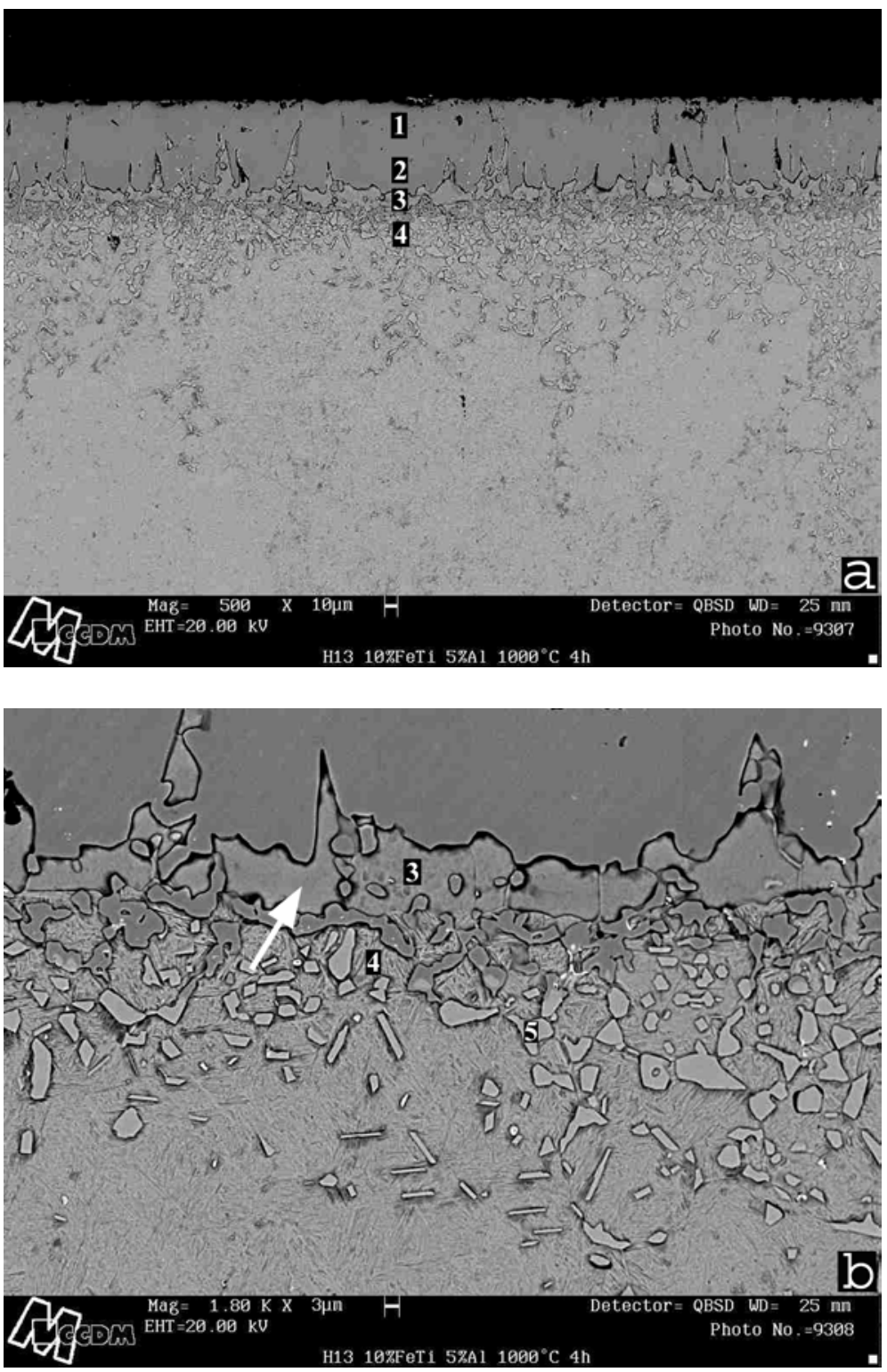

Figura 4.37 - (a) MEV do aço AISI H13 boretado no banho contendo $10 \% \mathrm{Fe}-\mathrm{Ti}+$ $5 \% \mathrm{Al}, 1000^{\circ} \mathrm{C} / 4 \mathrm{~h}$; (b) Mesma amostra, em aumento maior. Os pontos de 1-5 foram analisados por EDS. Camada boretada sobre a matriz martensítica. Ataque: Nital $3 \%$. 


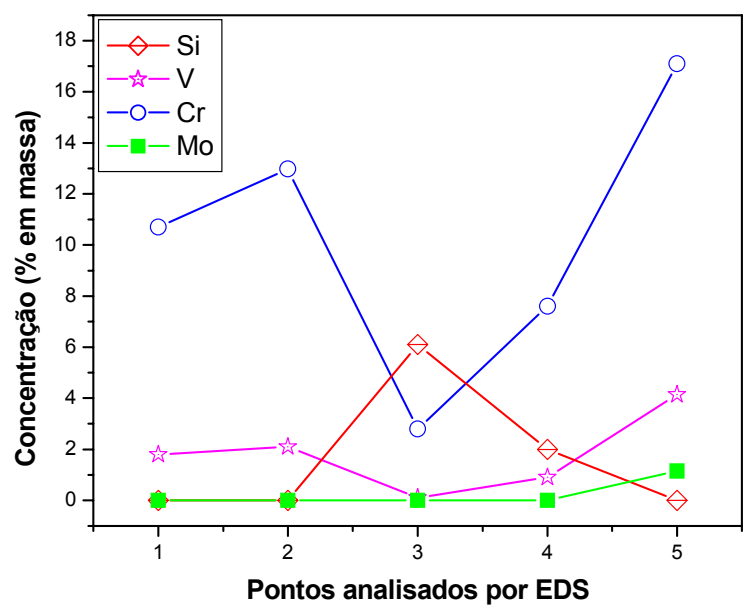

Figura 4.38 - Perfis de concentração de $\mathrm{Si}$, V, Mo e $\mathrm{Cr}$ na camada de boreto, determinados por EDS, nos pontos de 1-5, mostrados na figura 4.37. Aço AISI H13 tratado no banho contendo $10 \% \mathrm{Fe}-\mathrm{Ti}+5 \% \mathrm{Al}, 1000^{\circ} \mathrm{C} / 4 \mathrm{~h}$.

Os perfis de concentração dos elementos têm comportamentos similares, como pode observa-se nas figuras 4.38 e 4.40 . Nos dois casos, o silício está praticamente ausente na camada boretada (pontos 1 e 2), devido a sua baixa solubilidade, e se concentra no ponto 3 , que é a região da subcamada "mole", indicada pelas setas nas figuras 4.37b e 4.39b, resultado que está em concordância com a literatura (Chicco et al., 1998; Sinha, 1991). No ponto 4, localizado na zona intermediária, o teor de silício diminui consideravelmente em relação ao ponto 3 , e se torna praticamente zero na partícula indicada pelo ponto 5 , que provavelmente é constituída de boretos (Chicco et al., 1998). Os elementos $\mathrm{Cr}$ e $\mathrm{V}$ estão presentes na camada e apresentam suas menores concentrações na região da subcamada "mole" (ponto 3). Seus teores são maiores na partícula mostrada no ponto 5 , indicando que a mesma pode ser constituída de boretos desses elementos (Chicco et al., 1998). O cromo está presente na camada em grande quantidade, onde provavelmente forma boreto misto de cromo e ferro. Molibdênio só foi detectado na partícula identificada pelo ponto 5 . 

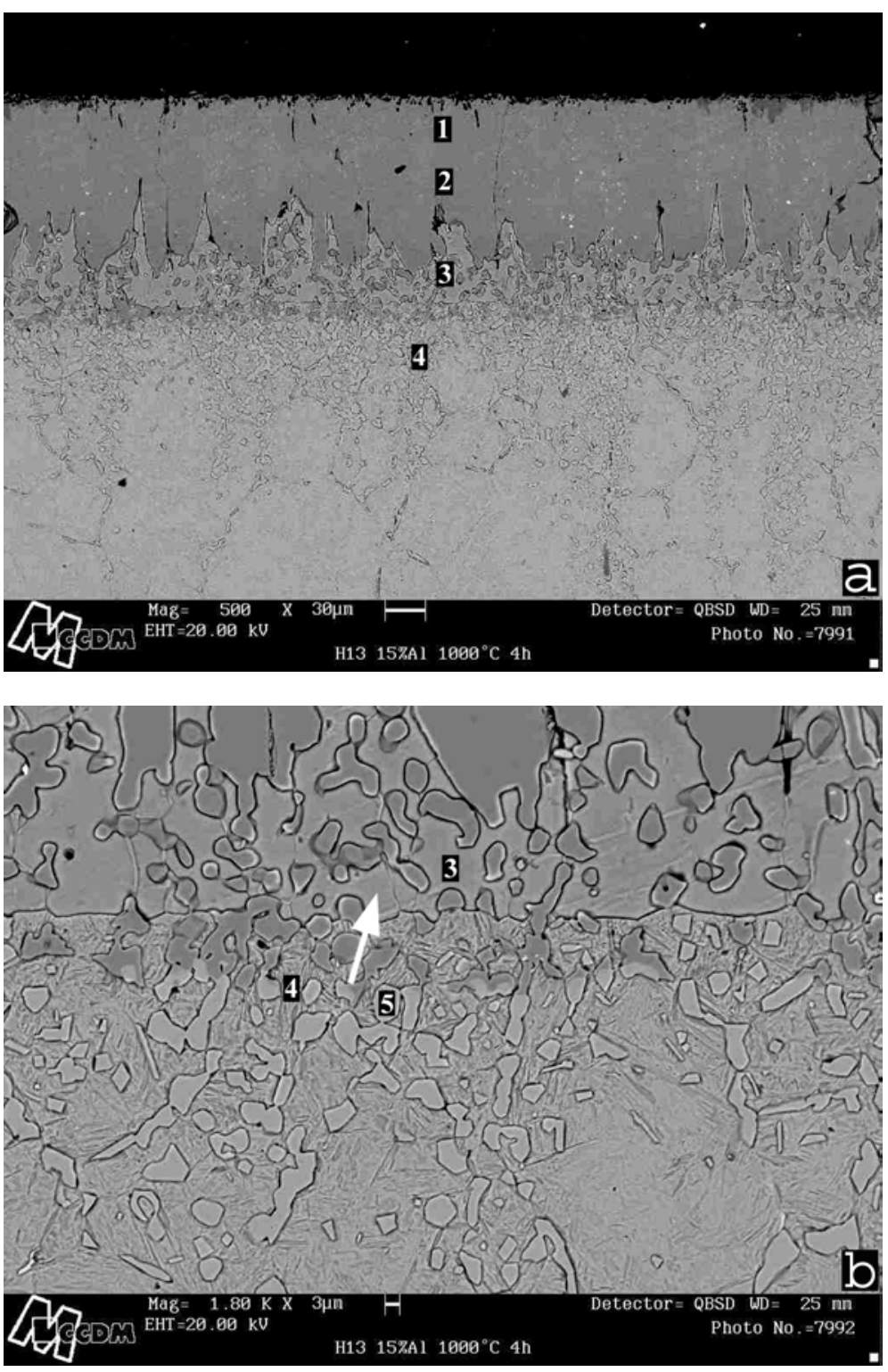

Figura 4.39 - (a) MEV do aço AISI H13 boretado no banho contendo 15\%Al, $1000^{\circ} \mathrm{C} / 4 \mathrm{~h}$; (b) Mesma amostra, em aumento maior. Os pontos de 1 a 5 foram analisados por EDS. Camada de boretos sobre a matriz martensítica. Ataque: Nital $3 \%$. 


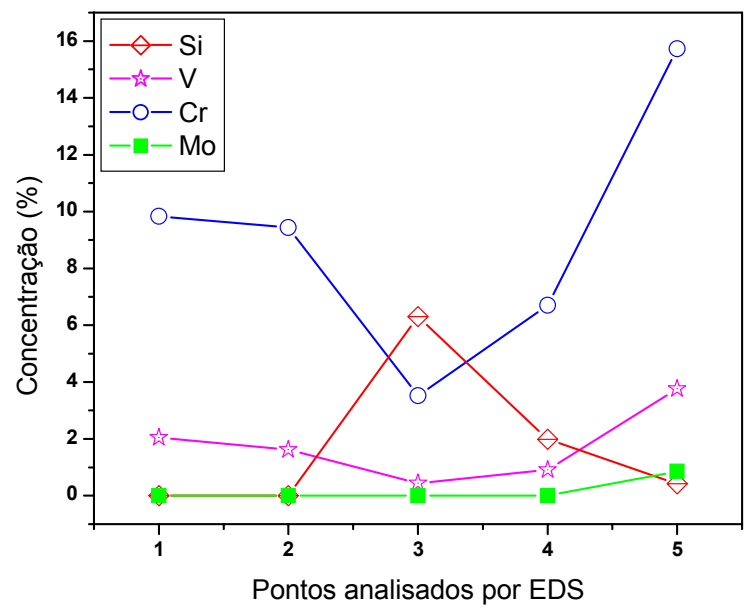

Figura 4.40 - Perfis de concentração de Si, V, Mo e Cr na camada de boreto, determinados por EDS, nos pontos de 1-5 (mostrados na figura 4.39). Aço AISI H13 tratado no banho contendo $15 \% \mathrm{Al}, 1000^{\circ} \mathrm{C} / 4 \mathrm{~h}$.

\subsubsection{Análises químicas pontuais das camadas boretadas produzidas no aço AISI D2}

Na figura 4.41 são mostradas as micrografias eletrônicas do aço AISI D2 boretado no banho contendo $10 \% \mathrm{Fe}-\mathrm{Ti}+5 \% \mathrm{Al}$, à $1000^{\circ} \mathrm{C} / 4 \mathrm{~h}$, indicando os pontos onde foram realizadas as análises por EDS. Os perfis de concentração dos elementos analisados são apresentados na figura 4.42. O silício praticamente não está presente na camada, assim como nos pontos 4 e 5 da zona de transição, tendo uma concentração relativamente alta no ponto 3. A maior concentração de silício nesse ponto deve-se provavelmente à sua expulsão da camada de boretos (Sinha, 1991). Apesar desta concentração de silício, não se observou a formação de uma subcamada ferrítica "mole", como ocorreu com o aço AISI H13. O carbono, que é um estabilizador da austenita e que está presente no aço AISI D2 em uma quantidade bem superior a do aço AISI H13, provavelmente dificultou a ação do silício em promover a formação da subcamada ferrítica "mole". O cromo tem suas maiores concentrações na camada (pontos 1 e 2), onde provavelmente forma boretos do tipo (Fe,Cr)B ou (Fe,Cr) $)_{2} \mathrm{~B}$ (Chicco et al., 1998). Na partícula mostrada 
no ponto 5 observa-se que cromo e molibdênio estão presentes, indicando que a partícula é provavelmente constituída de boretos mistos de $\mathrm{Cr}$, Mo e $\mathrm{Fe}$.
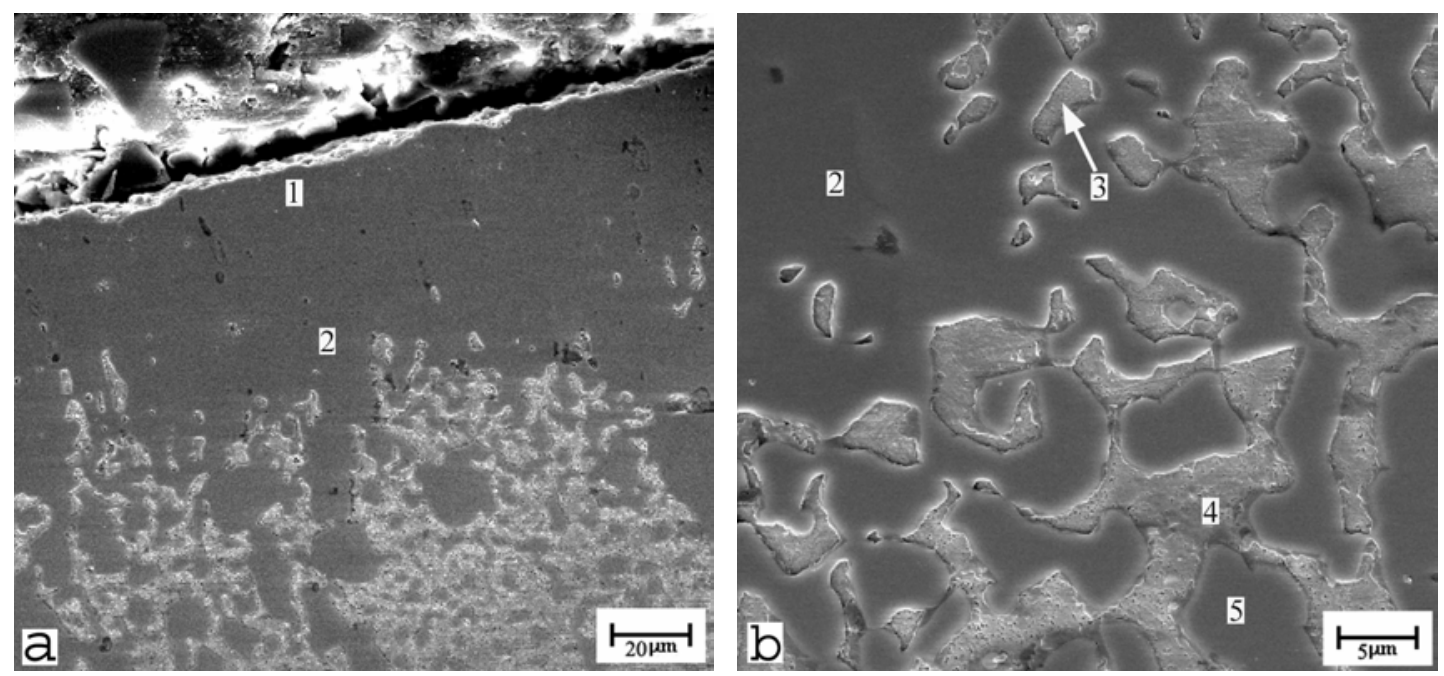

Figura 4.41 - (a) MEV do aço AISI D2, boretado no banho contendo $10 \% \mathrm{Fe}-\mathrm{Ti}+$ $5 \% \mathrm{Al}, 1000^{\circ} \mathrm{C} / 4 \mathrm{~h}$; (b) Mesma amostra, em aumento maior, destacando a zona de transição. Os pontos de 1-5 foram analisados por EDS. Ataque: Reagente de Vilella.

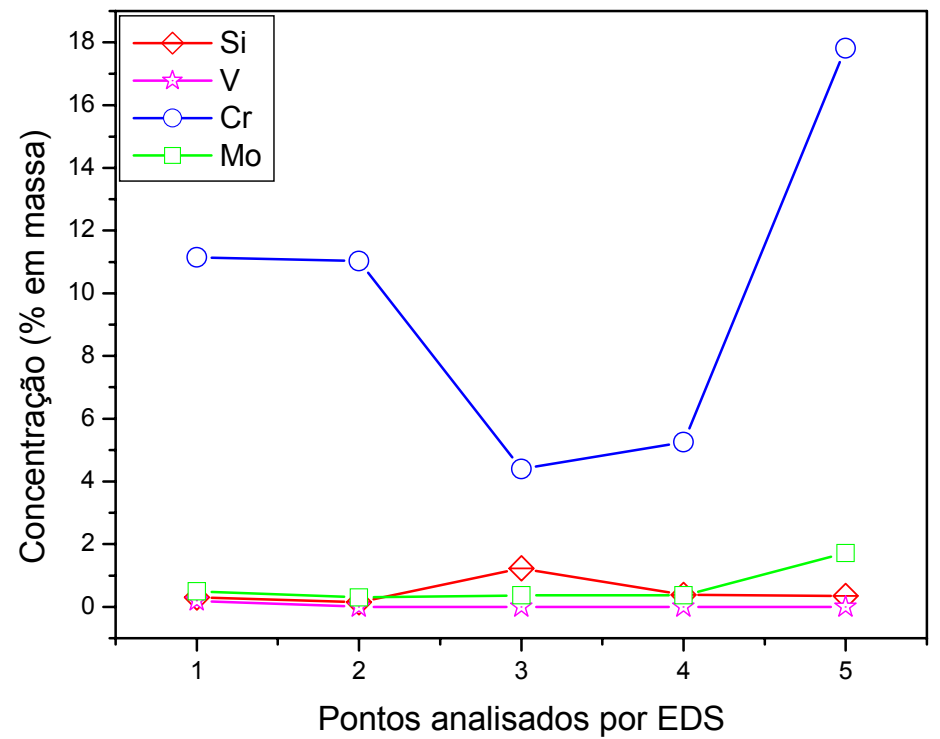

Figura 4.42 - Perfis de concentração de $\mathrm{Si}$, V, Mo e $\mathrm{Cr}$ na camada de boreto, determinados por EDS nos pontos de 1-5 (mostrados na figura 4.41). Aço AISI D2 tratado no banho contendo $10 \% \mathrm{Fe}-\mathrm{Ti} / 5 \% \mathrm{Al}, 1000^{\circ} \mathrm{C} / 4 \mathrm{~h}$. 
Nas figuras 4.43 a 4.46 são mostradas as micrografias eletrônicas obtidas por MEV e as curvas de concentrações dos elementos para aço AISI D2 tratado no banho contendo 15\%Al. As micrografias eletrônicas e os resultados das análises de EDS da amostra tratada à $1000^{\circ} \mathrm{C}$ encontram-se nas figuras 4.43 e 4.44 , enquanto para a amostra tratada à $800^{\circ} \mathrm{C}$, os resultados estão nas figuras 4.45 e 4.46 .

As curvas de concentração dos elementos, apresentadas nas figuras $4.44 \mathrm{e}$ 4.46, têm o mesmo comportamento apresentado pela amostra boretada no banho contendo $10 \% \mathrm{Fe}-\mathrm{Ti}+5 \% \mathrm{Al}$ (Fig. 4.42). O silício praticamente está ausente na camada (pontos 1 e 2), e tem sua maior concentração no ponto 3 . O cromo está presente na camada e, dentre os pontos analisados, tem uma concentração máxima na partícula mostrada no ponto 5 . O vanádio praticamente não foi detectado. O molibdênio apresenta um teor baixo nos pontos de 1-4, estando mais concentrado no ponto 5. As partículas localizadas na região de transição (ponto 5) provavelmente constituem-se de boretos mistos de cromo e molibdênio, com algum teor de ferro e vanádio (Chicco et al., 1998).

No caso da amostra tratada à $800^{\circ} \mathrm{C}$ observa-se uma menor variação nas concentrações dos elementos nos pontos analisados, o que é causado provavelmente pela difusividade menor nessa temperatura. Verifica-se que a concentração de cromo no ponto 5 é muito elevada (Fig. 4.46), indicando que a partícula é, provavelmente, um carboneto de cromo primário. 

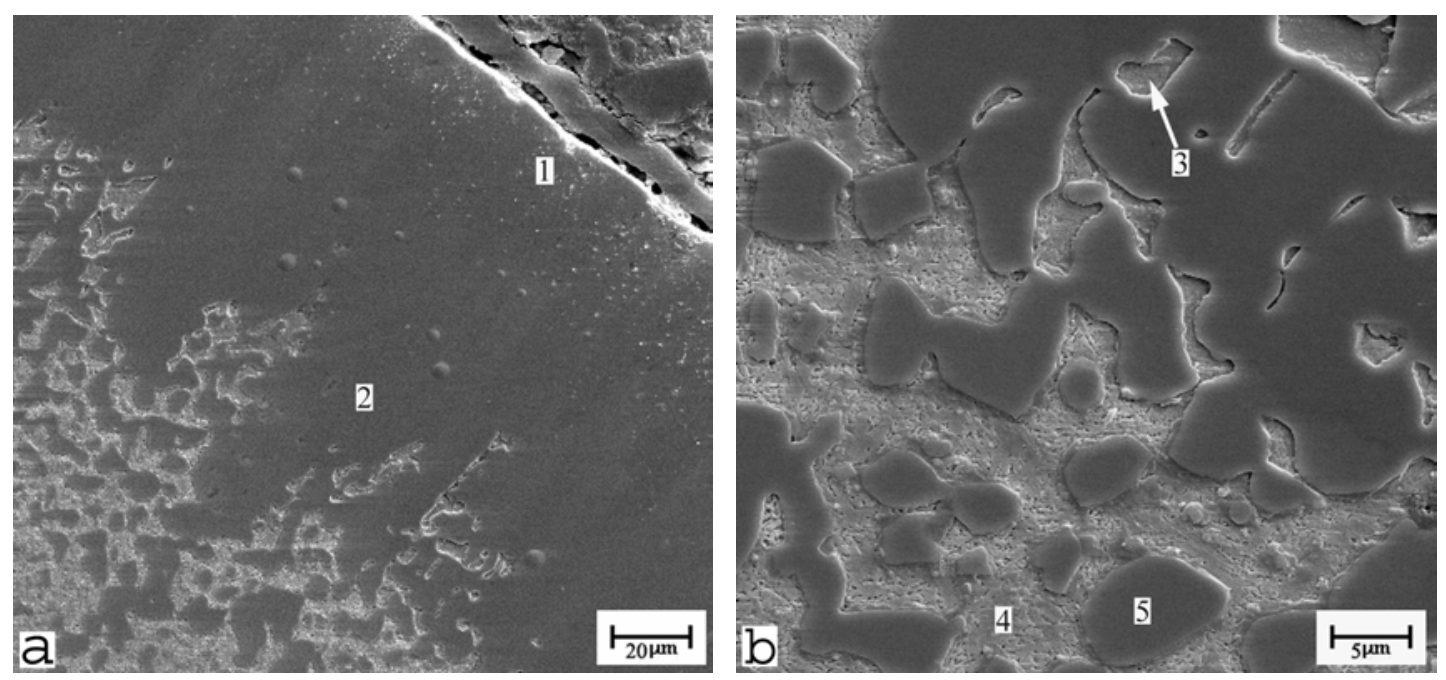

Figura 4.43 - (a) MEV do aço AISI D2, boretado no banho com adição de $15 \% \mathrm{Al}$, $1000^{\circ} \mathrm{C} / 4 \mathrm{~h}$; (b) Mesma amostra, em aumento maior, destacando a zona de transição. Os pontos de 1-5 foram analisados por EDS. Ataque: Reagente de Vilella.

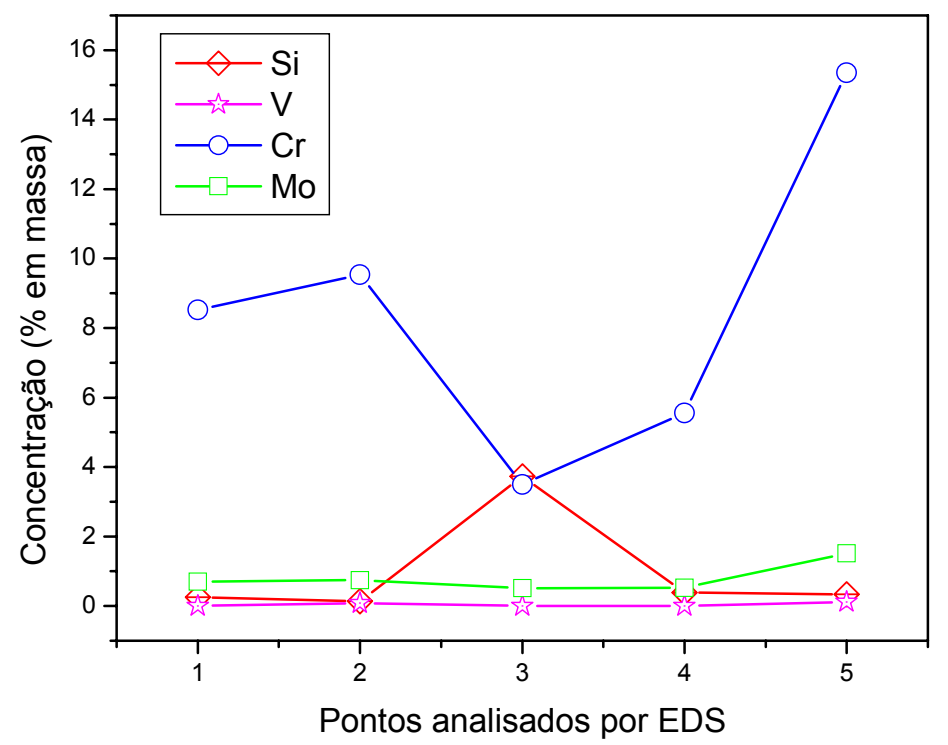

Figura 4.44 - Perfis de concentração de Si, V, Mo e $\mathrm{Cr}$ na camada de boreto, determinados por EDS nos pontos de 1-5 (mostrados na figura 4.43). Aço AISI D2 tratado no banho com adição de $15 \% \mathrm{Al}, 1000^{\circ} \mathrm{C} / 4 \mathrm{~h}$. 

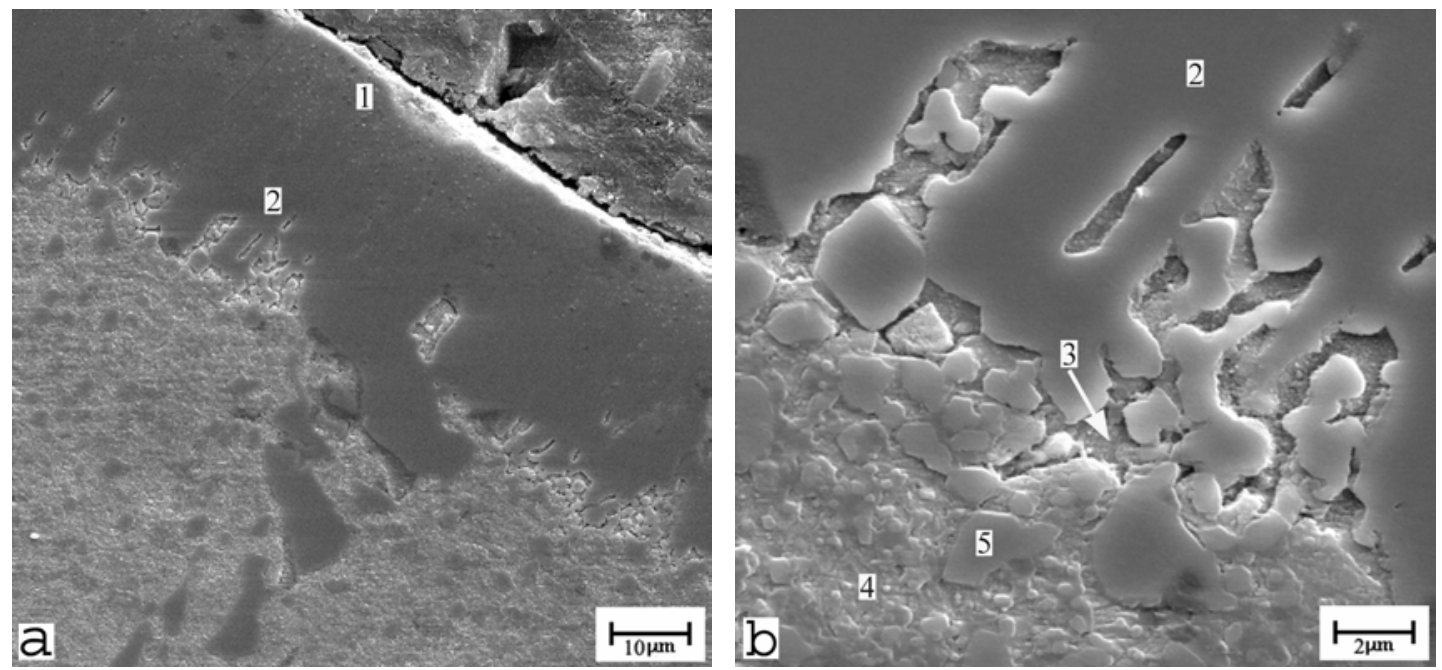

Figura 4.45 - (a) MEV do aço AISI D2, boretado no banho com adição de $15 \% \mathrm{Al}$, $800^{\circ} \mathrm{C} / 4 \mathrm{~h}$; (b) Mesma amostra, em aumento maior, destacando a zona de transição. Os pontos de 1-5 foram analisados por EDS. Ataque: Reagente de Vilella.

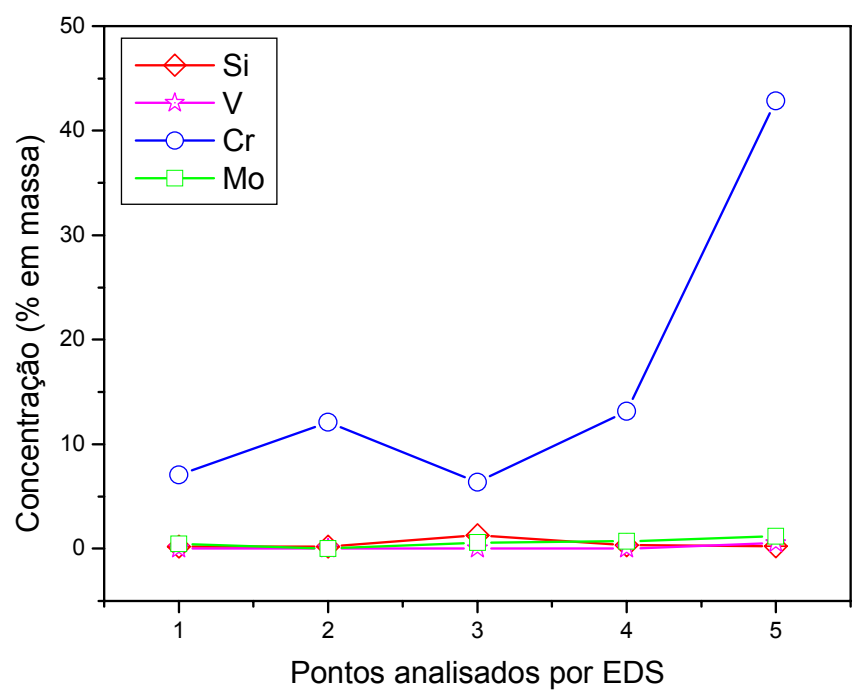

Figura 4.46 - Perfis de concentração de $\mathrm{Si}$, V, Mo e $\mathrm{Cr}$ na camada de boreto, determinados por EDS nos pontos de 1-5 (mostrados na figura 4.45). Aço AISI D2 tratado no banho com adição de $15 \% \mathrm{Al}, 800^{\circ} \mathrm{C} / 4 \mathrm{~h}$.

\subsubsection{Análises das camadas de boretos por meio da técnica de GDOS ("Glow} Discharge Optical Emission Spectroscopy")

As camadas boretadas obtidas nos aços AISI H13 e D2 foram analisadas por GDOS, técnica esta particularmente adequada para a determinação mais 
segura dos perfis de concentração dos elementos. Os perfis de concentração de B, $\mathrm{Fe}, \mathrm{Cr}$ e C, a partir da superfície em direção ao substrato, foram determinados quantitativamente.

\subsubsection{Análise de GDOS das camadas de boretos produzidas no aço AISI H13}

Os resultados das análises realizadas em amostras do aço AISI H13, tratadas nos banhos de bórax contendo $10 \% \mathrm{FeTi}+5 \% \mathrm{Al}$ e $15 \% \mathrm{Al}$, são apresentados nas figuras 4.47 e 4.48 , respectivamente. Na figura 4.49 são evidenciados os perfis de concentração de boro para as duas amostras, em maior escala, para facilitar a visualização. Nos dois casos, o teor de boro próximo à superfície encontra-se na faixa de 6-7\% (em massa) e diminui em direção ao substrato. Para o banho contendo $10 \% \mathrm{FeTi}+5 \% \mathrm{Al}$ (Figs. 4.47 e 4.49 ), o teor de boro diminuiu rapidamente, de forma que, a uma profundidade de $30 \mu \mathrm{m}$ sua concentração encontra-se em um patamar de 1,5\%, permanecendo com esse teor até aproximadamente $60 \mu \mathrm{m}$ de profundidade. Na faixa de 60 a $80 \mu \mathrm{m}$ de profundidade, o teor de boro diminui até desaparecer. Como mostrado na figura 4.47, o carbono apresenta um comportamento inverso ao do boro, com sua concentração aumentando à medida que o teor de boro diminui, indicando assim a sua baixa solubilidade na camada boretada (Sinha, 1991). A uma profundidade de $60 \mu \mathrm{m}$ ocorre um aumento do teor de carbono de forma mais acentuada. Com base nas análises dos perfis de concentração de boro e carbono, verifica-se que a espessura da camada situa-se entre 60 e $80 \mu \mathrm{m}$. Esse resultado está coerente com o valor de $70 \mu \mathrm{m}$, determinado na microscopia ótica. 


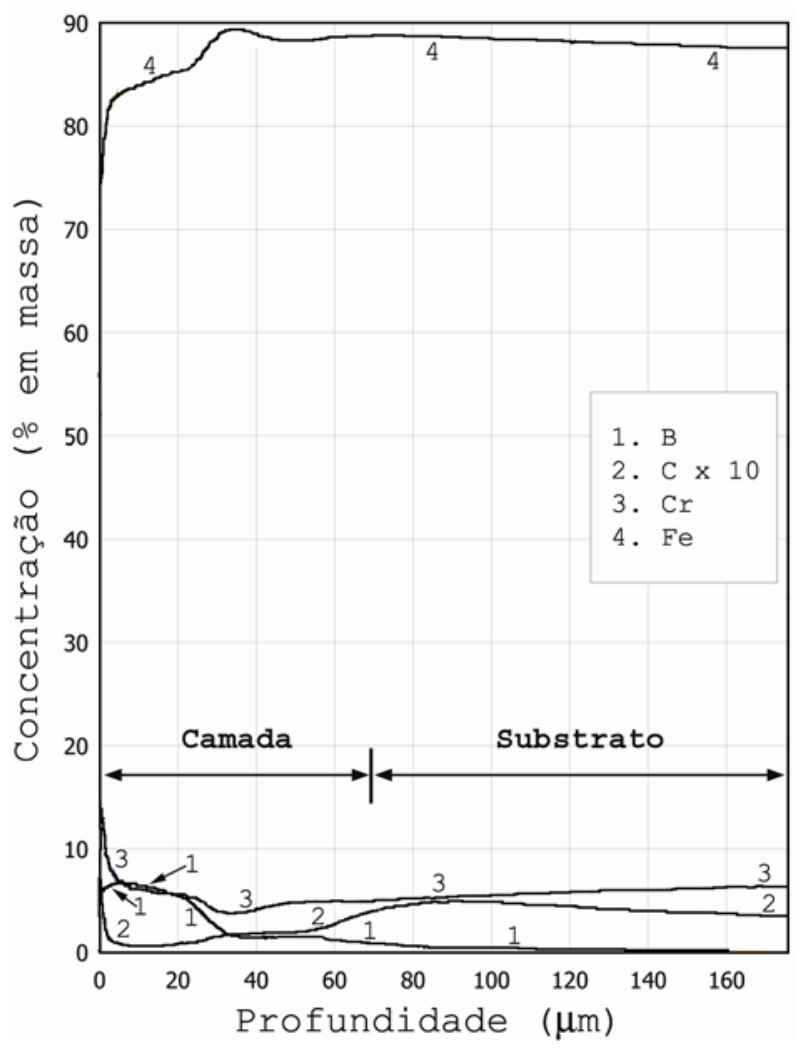

Figura 4.47 - Curvas de GDOS da camada de boreto obtida no aço AISI H13.

Banho: $10 \% \mathrm{FeTi} / 5 \% \mathrm{Al}$, à $1000^{\circ} \mathrm{C} / 4 \mathrm{~h}$.

As curvas de concentrações dos elementos, para o aço AISI H13 tratado no banho contendo $15 \% \mathrm{Al}$, apresentaram comportamentos similares aos verificados no caso do banho contendo $10 \% \mathrm{FeTi}+5 \% \mathrm{Al}$. Nas figuras 4.48 e 4.49 observa-se que a concentração de boro situa-se na faixa de 7 \% (em massa) próximo da superfície, diminuindo gradualmente em direção ao substrato, até uma profundidade de aproximadamente $100 \mu \mathrm{m}$. A partir desse ponto o teor de boro diminui, atingindo um valor de aproximadamente $1,6 \%$ a uma profundidade de $150 \mu \mathrm{m}$. Conforme determinado por microscopia ótica, a camada de boreto tem uma espessura média de $130 \mu \mathrm{m}$. Na figura 4.49 pode-se observar que a uma profundidade acima deste valor o boro ainda está presente, indicando que este elemento difundiu no substrato. Na figura 4.48 verifica-se a ausência de carbono na região 
correspondente a camada de boreto. Acima de aproximadamente $130 \mu \mathrm{m}$ o teor desse elemento aumenta gradualmente em direção ao substrato.

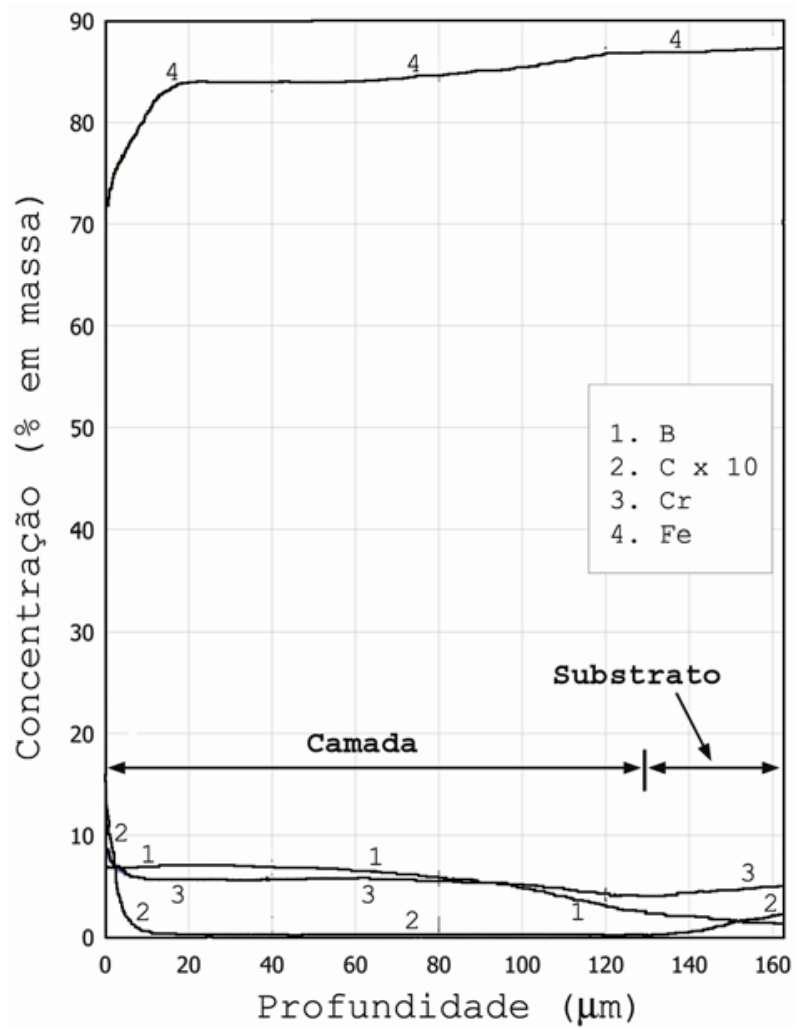

Figura 4.48 - Curvas de GDOS da camada de boreto obtida no aço AISI H13. Banho: $15 \% \mathrm{Al}$, à $1000^{\circ} \mathrm{C} / 4 \mathrm{~h}$.

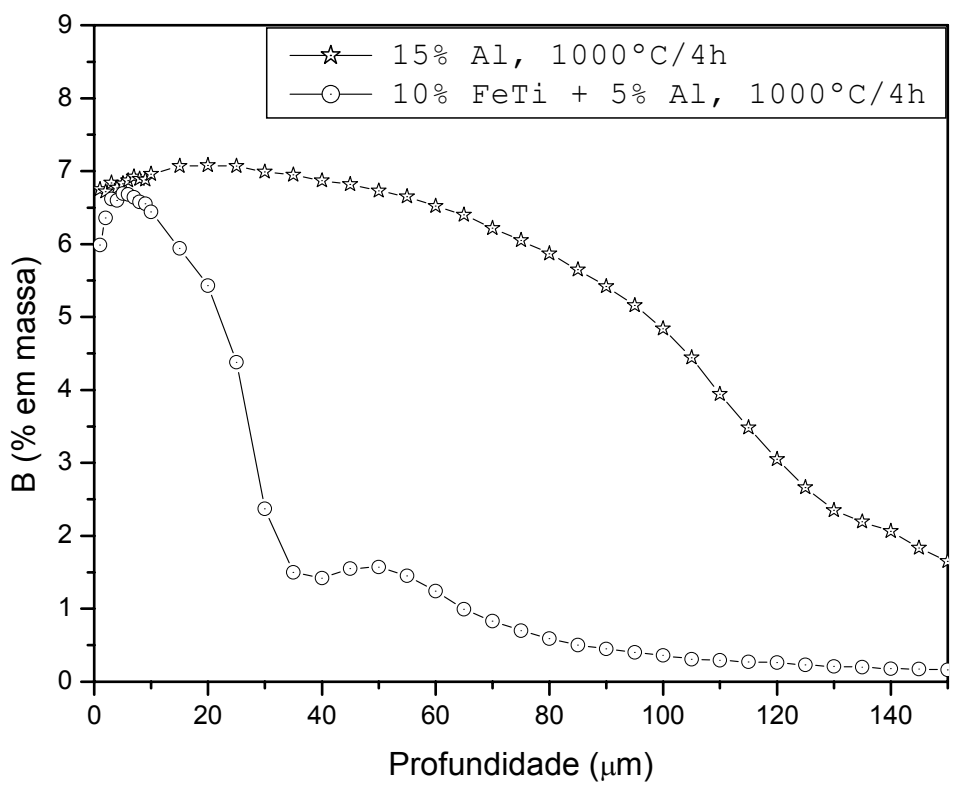

Figura 4.49 - Perfis de concentração de boro nas camadas de boretos obtidas no aço AISI H13, em diferentes composições de banhos. 


\subsubsection{Análise de GDOS das camadas de boretos produzidas no aço AISI D2}

No aço AISI D2, foram analisadas as camadas obtidas a 1000 e $800^{\circ} \mathrm{C}$, no banho contendo $15 \% \mathrm{Al}$, e a amostra tratada no banho com adição de $10 \% \mathrm{Fe}-\mathrm{Ti}+$ $5 \% \mathrm{Al}$, à $1000^{\circ} \mathrm{C}$. Nas figuras 4.50 a 4.52 apresentam-se os resultados gerais das análises de GDOS destas camadas, com os perfis de concentração de B, C, Fe e Cr, a partir da superfície em direção ao substrato. Na figura 4.53 são apresentados os resultados desses ensaios, nas três condições de tratamentos, referentes apenas às concentrações de boro, e em maior escala, para facilitar a visualização.

$\mathrm{Na}$ figura 4.50 registram-se as curvas obtidas por GDOS, com os perfis de concentração dos elementos na amostra do aço AISI D2 tratada no banho contendo $10 \% \mathrm{Fe}-\mathrm{Ti}+5 \% \mathrm{Al}$.

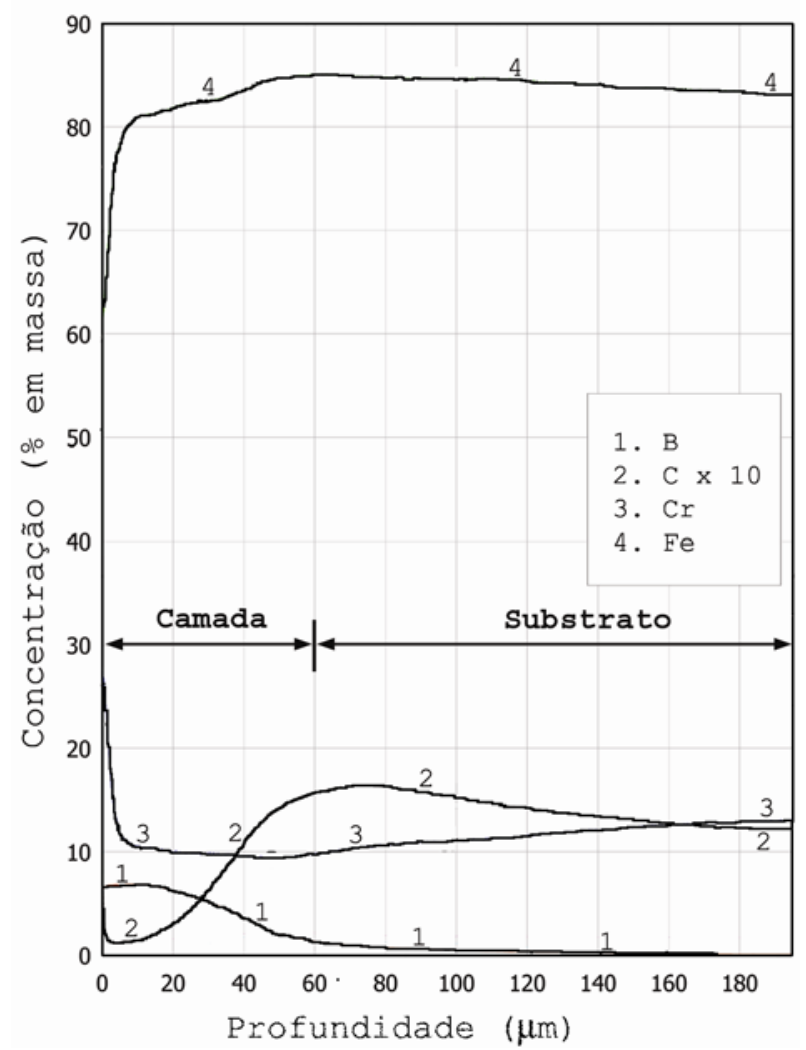

Figura 4.50 - Curvas de GDOS da camada obtida no aço AISI D2. Banho: $10 \% \mathrm{FeTi} / 5 \% \mathrm{Al}$, à $1000^{\circ} \mathrm{C} / 4 \mathrm{~h}$. 
O carbono apresenta-se em baixa concentração próximo à superfície da camada e aumenta gradualmente em direção ao substrato. Na faixa de 20 a $60 \mu \mathrm{m}$ apresenta um forte aumento, alcançando um teor superior ao do substrato. $\mathrm{O}$ teor de carbono superior ao do substrato pode ser atribuído à expulsão desse elemento pela frente de formação da camada de boreto. Verifica-se a presença do cromo em teores elevados na camada, indicando a possibilidade da existência de boretos mistos Fe-Cr. O teor médio de boro da superfície até a profundidade de $20 \mu \mathrm{m}$ é de 6,5\% (em massa), diminuindo a partir daí em direção ao substrato, o que pode ser verificado com maior detalhamento na figura 4.53. O comportamento inverso entre as curvas de boro e carbono indica a baixa solubilidade do carbono na camada de boretos.

As curvas obtidas por GDOS nas amostras do aço AISI D2 tratadas no tipo de banho contendo $15 \% \mathrm{Al}$, à $1000^{\circ} \mathrm{C}$ e à $800^{\circ} \mathrm{C}$, são mostradas nas figuras $4.51 \mathrm{e}$ 4.52, respectivamente. $\mathrm{Na}$ amostra tratada à $1000^{\circ} \mathrm{C}$ (Fig. 4.51) o teor de carbono na região da camada é muito baixo $(\sim 0,2 \%)$, aumentando gradativamente a partir do final da camada $(\sim 120 \mu \mathrm{m})$ em direção ao substrato, apresentando uma tendência de equalização. No tratamento realizado à $800^{\circ} \mathrm{C}$, verifica-se na figura 4.52 que o teor médio de carbono na camada foi de $0,5 \%$. Este teor de carbono mais elevado deve-se provavelmente a menor energia de ativação do processo para a sua difusão à frente da camada, o que acarreta a sua permanência na camada em maior quantidade. O cromo está presente na camada em um teor de aproximadamente $10 \%$, indicando a possibilidade da existência de boretos mistos Fe-Cr. A concentração superficial de boro nesses dois casos é o dobro da obtida no banho contendo $10 \% \mathrm{Fe}-\mathrm{Ti}+5 \% \mathrm{Al}$, situando-se em torno de $13 \%$ (em massa), decaindo rapidamente no caso da amostra tratada à $800^{\circ} \mathrm{C}$ a partir de $10 \mu \mathrm{m}$, devido à baixa energia de ativação para a formação da camada (Fig. 4.53). No caso da amostra tratada à $1000^{\circ} \mathrm{C}$ o decréscimo do teor de boro é mais suave. O potencial 
de boretação elevado do banho contendo $15 \% \mathrm{Al}$, combinado com a temperatura elevada do tratamento permitiu uma profundidade relativamente alta de penetração do boro.

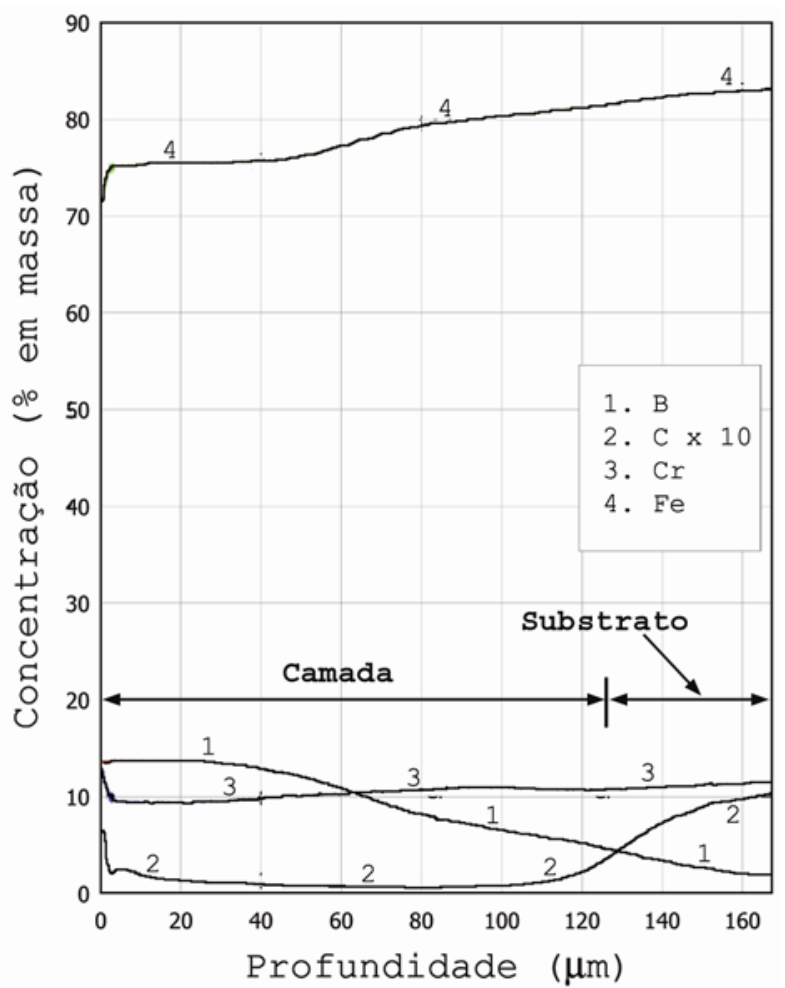

Figura 4.51 - Curvas de GDOS da camada obtida no aço AISI D2. Banho: 15\%Al, à $1000^{\circ} \mathrm{C} / 4 \mathrm{~h}$. 


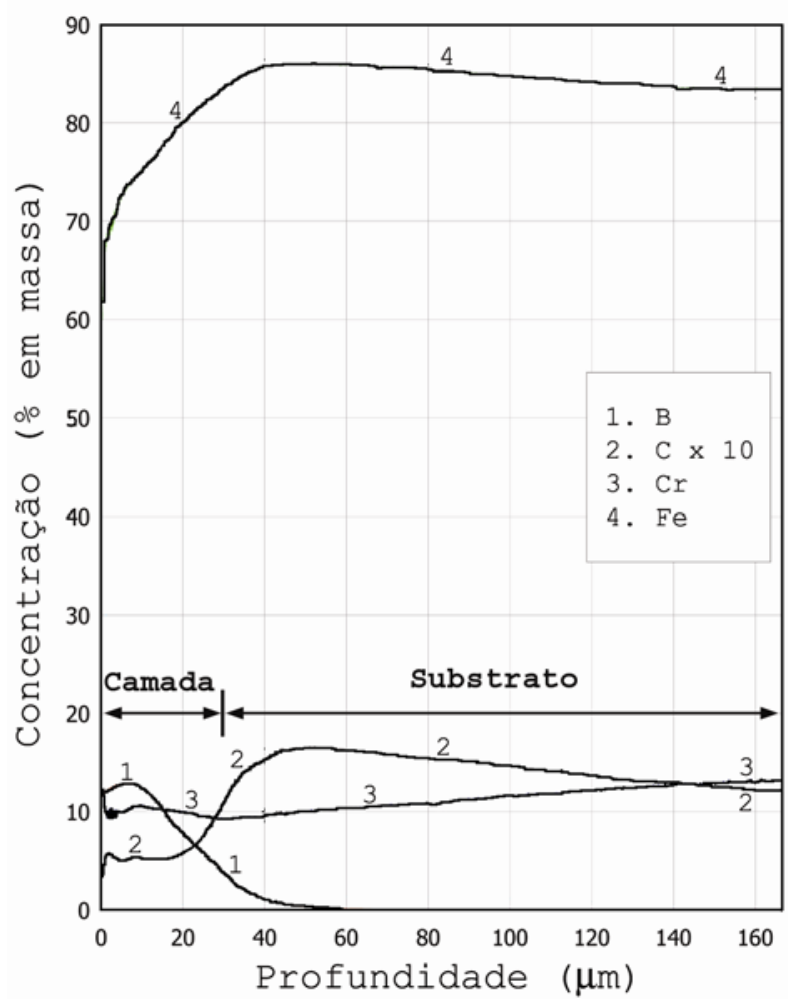

Figura 4.52 - Curvas de GDOS da camada de boreto obtida no aço AISI D2. Banho: $15 \% \mathrm{Al}$, à $800^{\circ} \mathrm{C} / 4 \mathrm{~h}$.

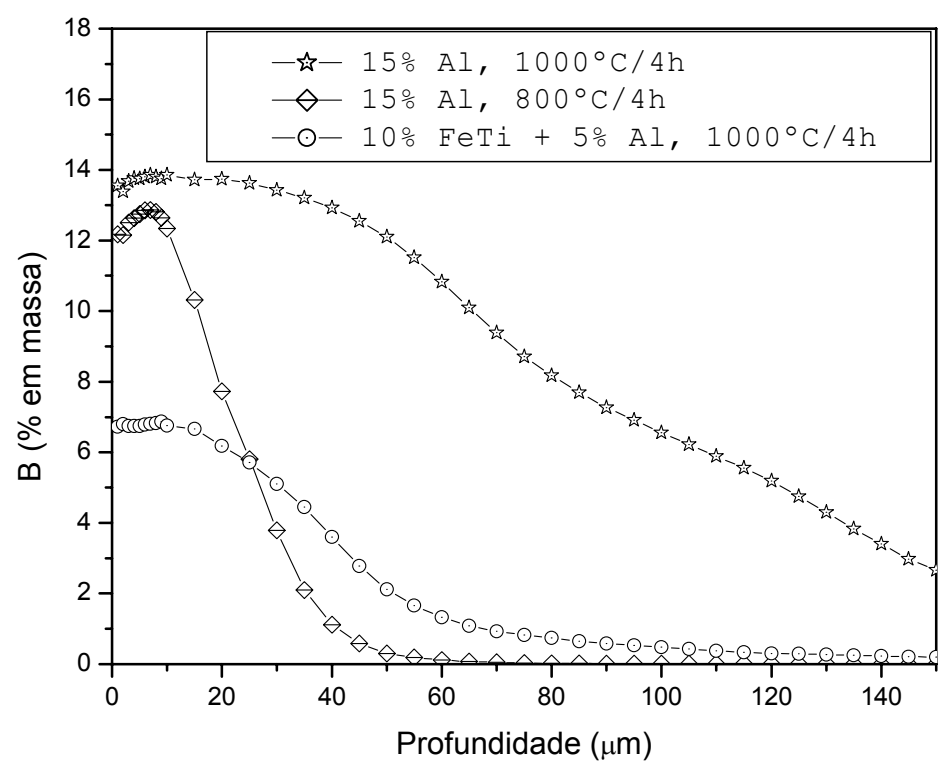

Figura 4.53 - Perfis de concentração de boro nas camadas de boretos obtidas no aço AISI D2, em diferentes condições de banhos e de tratamentos. 


\subsubsection{Análise das relações Fe/B das camadas de boretos produzidas nos aços AISI H13 e D2}

$\mathrm{Na}$ tabela 4.7 evidenciam-se as relações Fe/B (\% atômica) das camadas boretadas, em função da profundidade da camada, obtidas a partir das análises de GDOS.

Para o aço AISI H13 tratado no banho contendo 10\%FeTi + 5\%Al, tem-se a relação $\mathrm{Fe} / \mathrm{B} \cong 2,5$, próximo à superfície, e para o banho com adição de $15 \% \mathrm{Al}$, o valor de Fe/B é igual a 2,2. Esses níveis de concentrações de boro estão coerentes com a fase $\mathrm{Fe}_{2} \mathrm{~B}$ identificada também pelas análises de raios-X (Figs. 4.21 e 4.30).

No caso do aço AISI D2, pelos dados da tabela 4.7, verifica-se próximo à superfície, a relação $\mathrm{Fe} / \mathrm{B} \cong 1,1$ para as camadas obtidas nos banhos com adição de $15 \% \mathrm{Al}$, nas temperaturas de 800 e $1000^{\circ} \mathrm{C}$, indicando a presença da fase FeB, que foi também detectada na difração de raios-X (Figs. 4.34 e 4.36). Para a camada obtida no banho contendo $10 \% \mathrm{Fe}-\mathrm{Ti}+5 \% \mathrm{Al}$ a relação $\mathrm{Fe} / \mathrm{B}$ foi igual a 2,2, indicando a fase $\mathrm{Fe}_{2} \mathrm{~B}$, o que também está em concordância com a análise de raios-X (Fig. 4.23).

As relações $\mathrm{Fe} / \mathrm{B}$ e os teores de $\mathrm{Cr}$ verificados nas análises de GDOS indicam a possibilidade de formação de boretos dos tipos (Fe, $\mathrm{Cr})_{2} \mathrm{~B}$ e $(\mathrm{Fe}, \mathrm{Cr}) \mathrm{B}$ nas camadas obtidas nos dois aços.

Tabela 4.7 - Relação Fe/B (em \% atômica) nas camadas boretadas, em função da profundidade da camada.

\begin{tabular}{|c|c|c|c|c|c|}
\hline $\begin{array}{c}\text { Profundida } \\
\text { de }(\mu \mathrm{m})\end{array}$ & $\begin{array}{c}\mathrm{H} 13 \\
15 \% \mathrm{Al} \\
1000^{\circ} \mathrm{C}\end{array}$ & $\begin{array}{c}\mathrm{H} 13 \\
\mathrm{FeTi} / \mathrm{Al} \\
1000^{\circ} \mathrm{C}\end{array}$ & $\begin{array}{c}\mathrm{D} 2 \\
15 \% \mathrm{Al} \\
1000^{\circ} \mathrm{C}\end{array}$ & $\begin{array}{c}\mathrm{D} 2 \\
15 \% \mathrm{Al} \\
800^{\circ} \mathrm{C}\end{array}$ & $\begin{array}{c}\mathrm{D} 2 \\
\mathrm{FeTi} / \mathrm{Al} \\
1000^{\circ} \mathrm{C}\end{array}$ \\
\hline 1 & 2,09 & 2,52 & 1,07 & 1,1 & 2,2 \\
\hline 5 & 2,15 & 2,43 & 1,06 & 1,09 & 2,24 \\
\hline 10 & 2,22 & 2,53 & 1,05 & 1,18 & 2,3 \\
\hline 20 & 2,27 & 3,06 & 1,06 & 2,01 & 2,6 \\
\hline
\end{tabular}




\subsection{Microdurezas Vickers das camadas de carbonetos}

Devido às espessuras relativamente baixas das camadas de carbonetos, as medidas de microdurezas foram realizadas nos topos das camadas. Nas figuras 4.54 e 4.55 são mostradas as indentações Vickers nas superfícies das camadas e dos substratos, e na tabela 4.8 são apresentados seus valores de dureza.

As impressões obtidas nas camadas de carbonetos são muito menores do que as indentações formadas nas amostras não revestidas, indicando seus altos níveis de dureza.
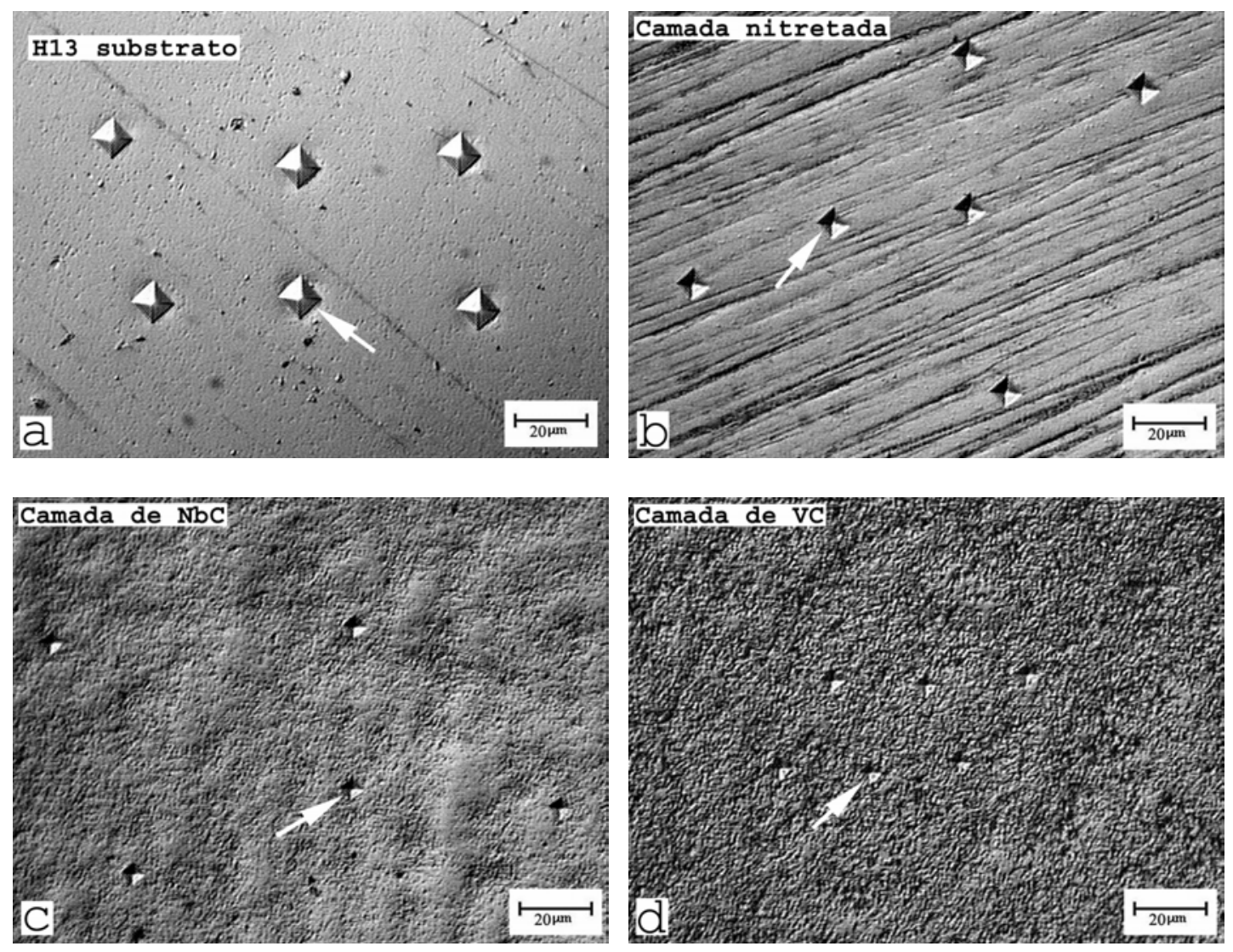

Figura 4.54 - Indentações Vickers na superfície do aço H13 substrato (Temperado e revenido), e com diferentes tipos de camadas. Setas destacam as indentações.

Carga aplicada: 50gf. 

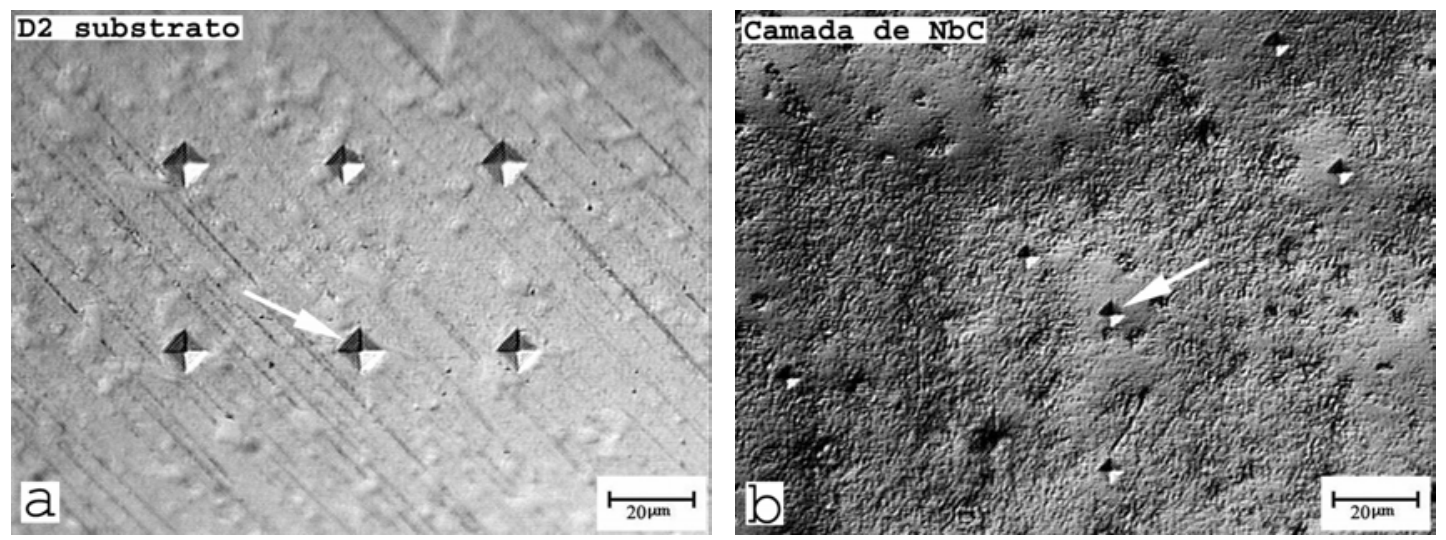

Figura 4.55 - Indentações Vickers na superfície do aço D2 substrato (Temperado e revenido), e com diferentes tipos de camadas. Setas destacam as indentações. Carga aplicada: $50 \mathrm{gf}$.

$\mathrm{Na}$ tabela 4.8 apresentam-se os valores das durezas das camadas de $\mathrm{NbC}$ e VC obtidas nos aços AISI H13 e D2, da camada nitretada produzida no aço AISI $\mathrm{H} 13$ e dos substratos temperados e revenidos. As durezas das camadas de $\mathrm{NbC}$ obtidas nos aços AISI H13 e D2 foram de 2338,2 e 2353,0 HV, respectivamente. A semelhança desses valores é explicada pelo fato das camadas serem constituídas pelo mesmo tipo de carboneto $(\mathrm{NbC})$. No caso das camadas de VC formadas no aço AISI H13, a dureza foi de 2470,7 HV e para a camada no aço AISI D2 a dureza foi de 2460,8 HV. Tais níveis de dureza obtidos são compatíveis com os valores encontrados na literatura (Child et al., 1984; Sricharoenchai et al., 1998; Chicco et al., 1999).

Tabela 4.8 - Microdurezas Vickers $\left(\mathrm{HV}_{0,050}\right)$ dos aços AISI H13 e D2, substratos e revestidos.

\begin{tabular}{||c|c|c|c|c||}
\hline \hline Aço & TR & Nitretado & NbC & VC \\
\hline & 663,7 & 1130,7 & 2338,2 & 2470,7 \\
H13 & $\pm 27,4$ & $\pm 36,3$ & $\pm 100,0$ & $\pm 109,4$ \\
\hline D2 & 679,4 & - & 2353,0 & 2460,8 \\
& $\pm 36,4$ & & $\pm 91,8$ & $\pm 93,2$ \\
\hline
\end{tabular}




\subsection{Microdureza Vickers das camadas de boretos}

As maiores espessuras das camadas de boretos permitiram as medições das durezas transversalmente às mesmas.

Nas figuras 5.56 e 5.57 são apresentadas as micrografias das camadas e substratos, juntamente com suas respectivas curvas de microdureza Vickers.

Os perfis de microdureza das camadas de boretos obtidas nos aços AISI H13 e D2 tratados no banho contendo $10 \% \mathrm{Fe}-\mathrm{Ti}+5 \% \mathrm{Al}$, são mostrados na figura 4.56. Verifica-se que nos dois casos acima, a dureza da camada próximo à superfície encontra-se em torno de $1600 \mathrm{HV}$, diminuindo em direção ao substrato. No caso do aço AISI H13 (Fig. 4.56a), observa-se a acentuada queda de dureza abaixo da camada boretada para um patamar de aproximadamente $400 \mathrm{HV}$, que é inferior a dureza do substrato, indicando a presença da "subcamada ferrítica mole". Este valor de dureza, que é relativamente elevado para uma estrutura ferrítica, foi provavelmente influenciado pelas fases de boretos presentes. No caso do aço AISI D2 (Fig. 4.56b), verifica-se uma dureza relativamente elevada na região de transição, indicando que não ocorreu a formação da "subcamada mole".

Na figura 4.57 apresentam-se os perfis de microdurezas para as amostras tratadas no banho contendo 15\%Al. Observa-se nos dois aços uma dureza média da camada de 1700 HV próximo à superfície, diminuindo gradualmente em direção ao substrato. No aço AISI H13 (Fig. 4.57a) pode-se constatar a baixa dureza na região da "subcamada mole", o que não ocorreu no aço AISI D2.

Pelas análises das curvas de microdureza e da tabela 4.9, verifica-se que as camadas produzidas a $1000^{\circ} \mathrm{C}$ apresentaram níveis de durezas semelhantes para o caso dos banhos com adições de 10 e 15\%Al ( 1700HV). No caso dos banhos contendo $10 \% \mathrm{Fe}-\mathrm{Ti}+5 \% \mathrm{Al}$ ocorreu uma pequena queda de dureza $(\sim 1600 \mathrm{HV})$, tendo o mesmo acontecido para a amostra do aço AISI D2 tratada a $800^{\circ} \mathrm{C}$ no banho contendo 15\%Al. Tais níveis de dureza estão de acordo com os resultados 
encontrados na literatura para camadas boretadas (Kulka e Pertek, 2003; Ozbek e Bindal, 2002; Sen et al., 2005a).
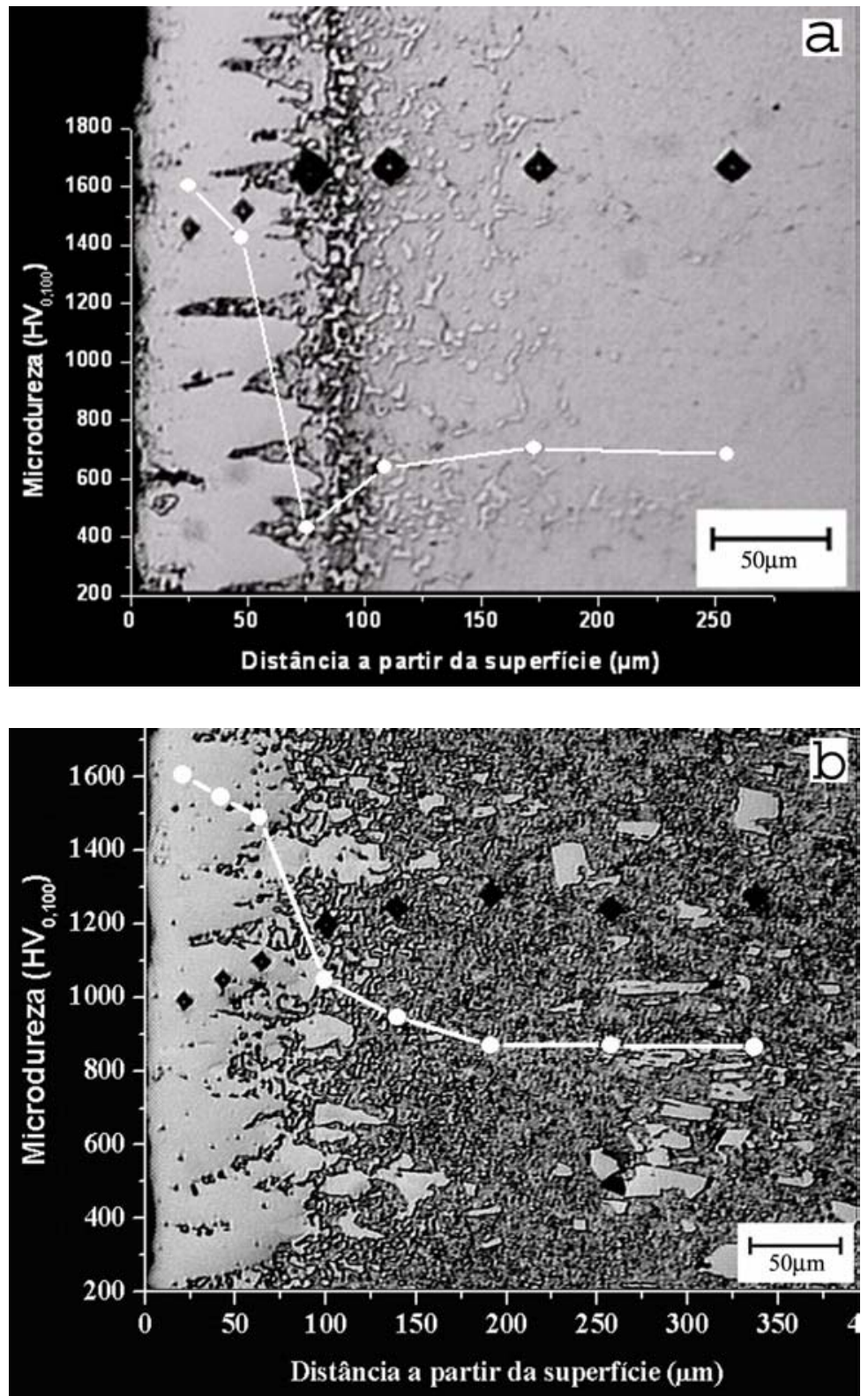

Figura 4.56 - Perfis de microdureza Vickers das camadas de boretos obtidas no banho contendo $10 \% \mathrm{FeTi} / 5 \% \mathrm{Al}$, à $1000^{\circ} \mathrm{C} / 4 \mathrm{~h}$ : (a) aço AISI H13, (b) aço AISI D2. Ataque: Reagente de Vilella. 

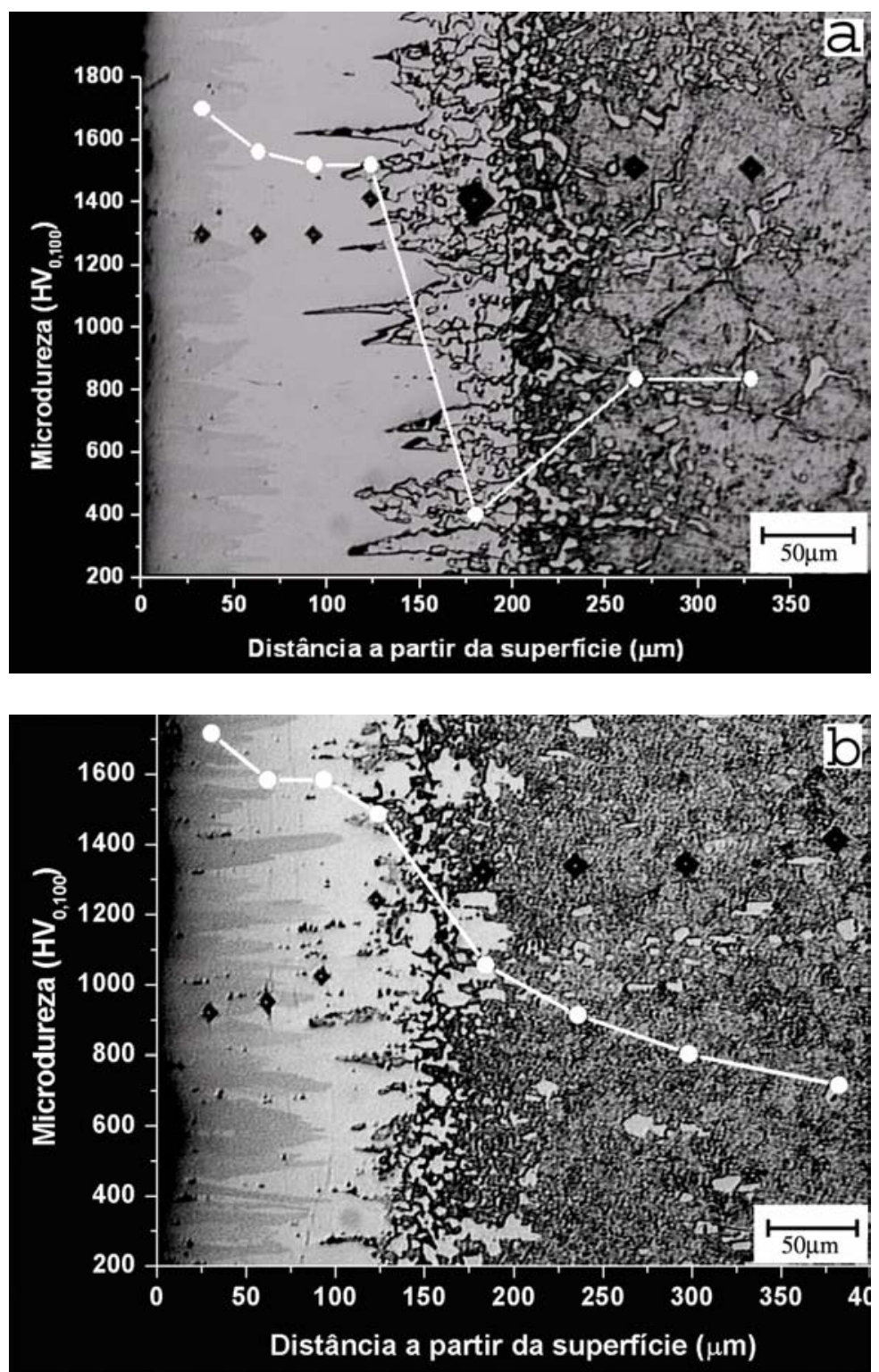

Figura 4.57 - Perfis de microdureza Vickers das camadas de boretos, obtidas no banho contendo $15 \% \mathrm{Al}$, à $1000^{\circ} \mathrm{C} / 4 \mathrm{~h}$ : (a) aço AISI H13, (b) aço AISI D2. Ataque: Reagente de Vilella.

Tabela 4.9 - Microdurezas Vickers $\left(\mathrm{HV}_{0,050}\right)$ das camadas boretadas obtidas em diferentes composições de banho, à $1000^{\circ} \mathrm{C}$.

\begin{tabular}{|c|c|c|c|c|c||}
\hline \hline Aço & TR & Fe-Ti & $10 \% \mathrm{Al}$ & $15 \% \mathrm{Al}$ & $15 \% \mathrm{Al}^{*}$ \\
\hline \multirow{2}{*}{ AISI H13 } & 663,7 & 1582,7 & 1706,3 & 1722,2 & - \\
& $\pm 27,4$ & $\pm 69,3$ & $\pm 66,1$ & $\pm 56,9$ & \\
\hline \multirow{2}{*}{ AIS D2 } & 679,1 & 1596,0 & 1717,4 & 1741,6 & 1616,4 \\
& $\pm 36,4$ & $\pm 60,9$ & $\pm 55,3$ & $\pm 48,7$ & $\pm 40,8$ \\
\hline
\end{tabular}

* Realizado à $800^{\circ} \mathrm{C}$. 


\subsection{Aderência das camadas de carbonetos e de boretos}

Indentações Vickers, com cargas crescentes, foram aplicadas nas interfaces camada/substrato para se avaliar a ligação das camadas de NbC, VC e Fe-B com os substratos. Nas figuras 4.58 a 4.60 são apresentadas as micrografias óticas mostrando as indentações mais representativas produzidas nas interfaces dessas camadas com seus respectivos substratos. O fator limitante das cargas aplicadas foram as espessuras das camadas, uma vez que a parte da impressão contida na camada não poderia logicamente exceder sua espessura. Verifica-se a excepcional aderência das camadas aos substratos em todos os casos, não tendo ocorrido qualquer destacamento da camada ou o aparecimento de trincas nas interfaces.
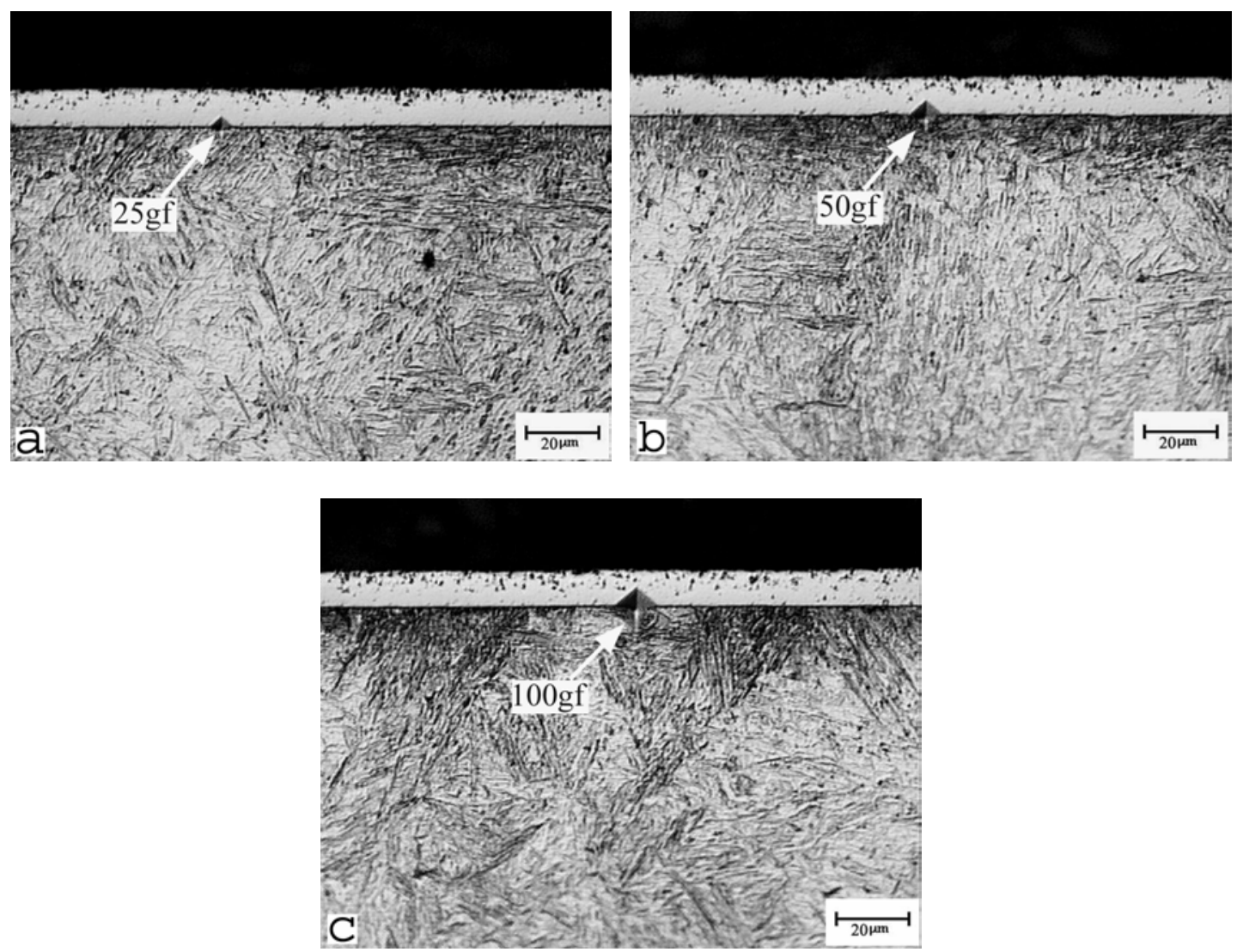

Figura 4.58 - Indentações Vickers na interface da camada de $\mathrm{NbC}$ com o substrato (aço AISI H13). Camada obtida à $1000^{\circ} \mathrm{C} / 9 \mathrm{~h}$. Não se formaram trincas. Ataque: Reagente de Vilella. 

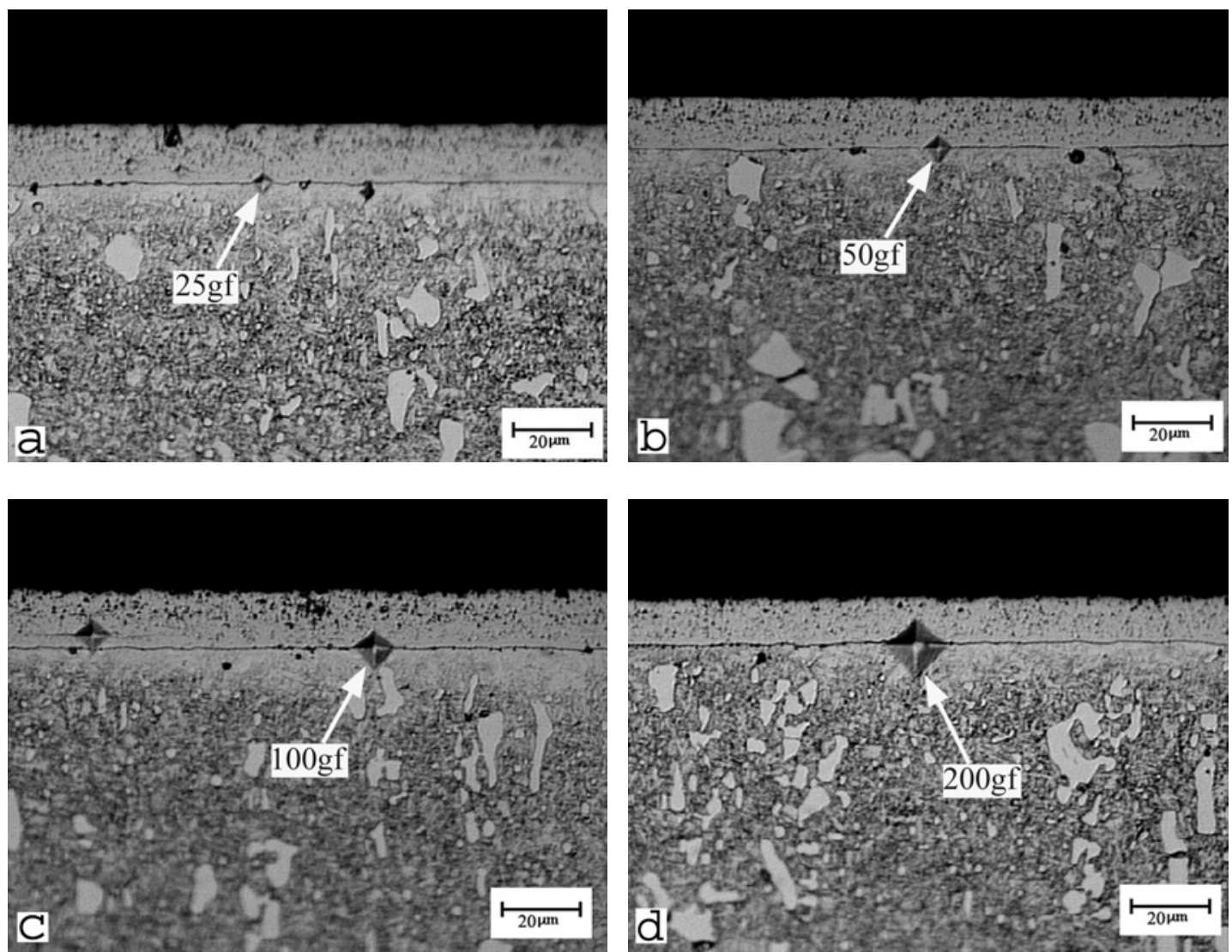

Figura 4.59 - Indentações Vickers na interface da camada de VC com o substrato (aço AISI D2). Camada obtida à $1000^{\circ} \mathrm{C} / 4 \mathrm{~h}$. Ataque: Reagente de Vilella.

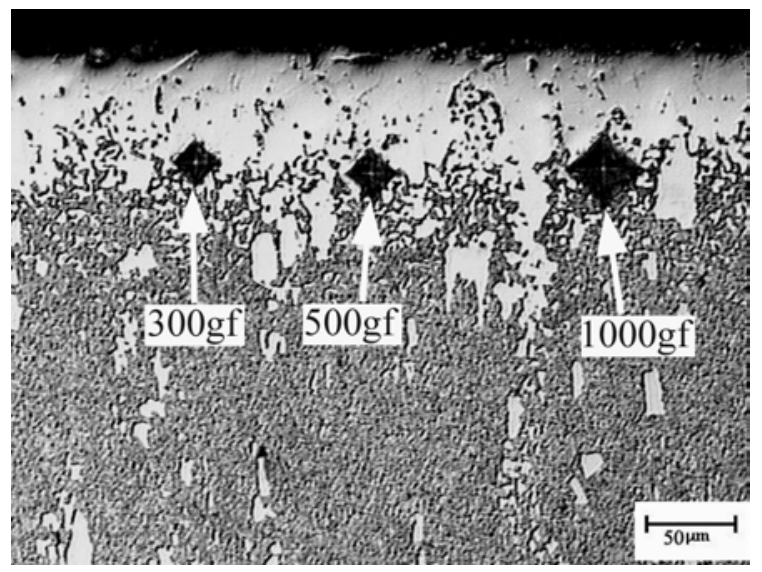

Figura 4.60 - Indentações Vickers na interface da camada de Fe-B com o substrato (aço AISI D2). Camada obtida à $1000^{\circ} \mathrm{C} / 4 \mathrm{~h}$. Ataque: Reagente de Vilella. 


\subsection{Resistência ao desgaste em micro-escala das camadas de carbonetos e}

\section{de boretos}

Na figura 4.61 são mostradas as curvas de desgaste em micro-escala do aço AISI H13 temperado e revenido e dos diferentes tipos de camadas produzidas no mesmo, para fins de comparação. Os volumes das calotas de desgaste obtidas foram relacionados com as distâncias de deslizamento.

As amostras revestidas apresentaram resistências ao desgaste consideravelmente superiores a do aço AISI H13 substrato, demonstrando a efetividade dos processos empregados. Os melhores desempenhos foram os das camadas de $\mathrm{NbC}$ e $\mathrm{VC}$, que não apresentaram diferenças significativas entre si quanto ao desgaste, devido provavelmente, aos seus níveis de dureza semelhantes.

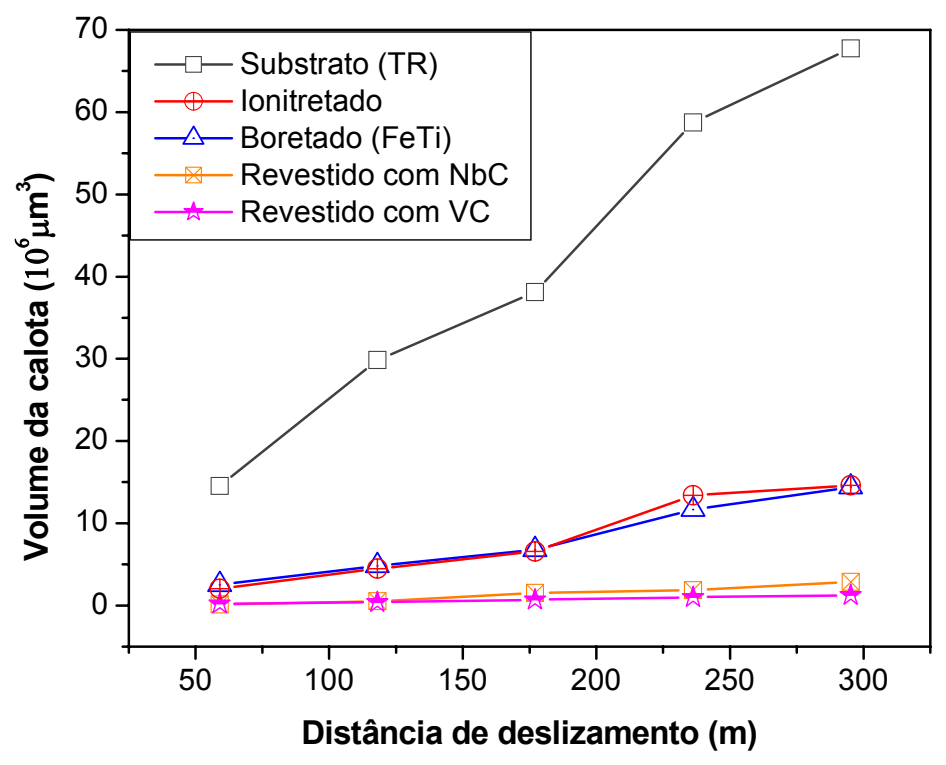

Figura 4.61 - Curvas de desgaste em micro-escala para o aço AISI H13: temperado/revenido (TR) e revestido com camadas de nitretos, carbonetos e boretos. 
As calotas de desgaste formadas nas camadas e no substrato do aço AISI H13, para uma distância de deslizamento de $177 \mathrm{~m}$, são mostradas na figura 4.62. $\mathrm{Na}$ camada de NbC (Fig. 4.62d) uma calota obtida para uma distância de deslizamento de $118 \mathrm{~m}$ também é mostrada.
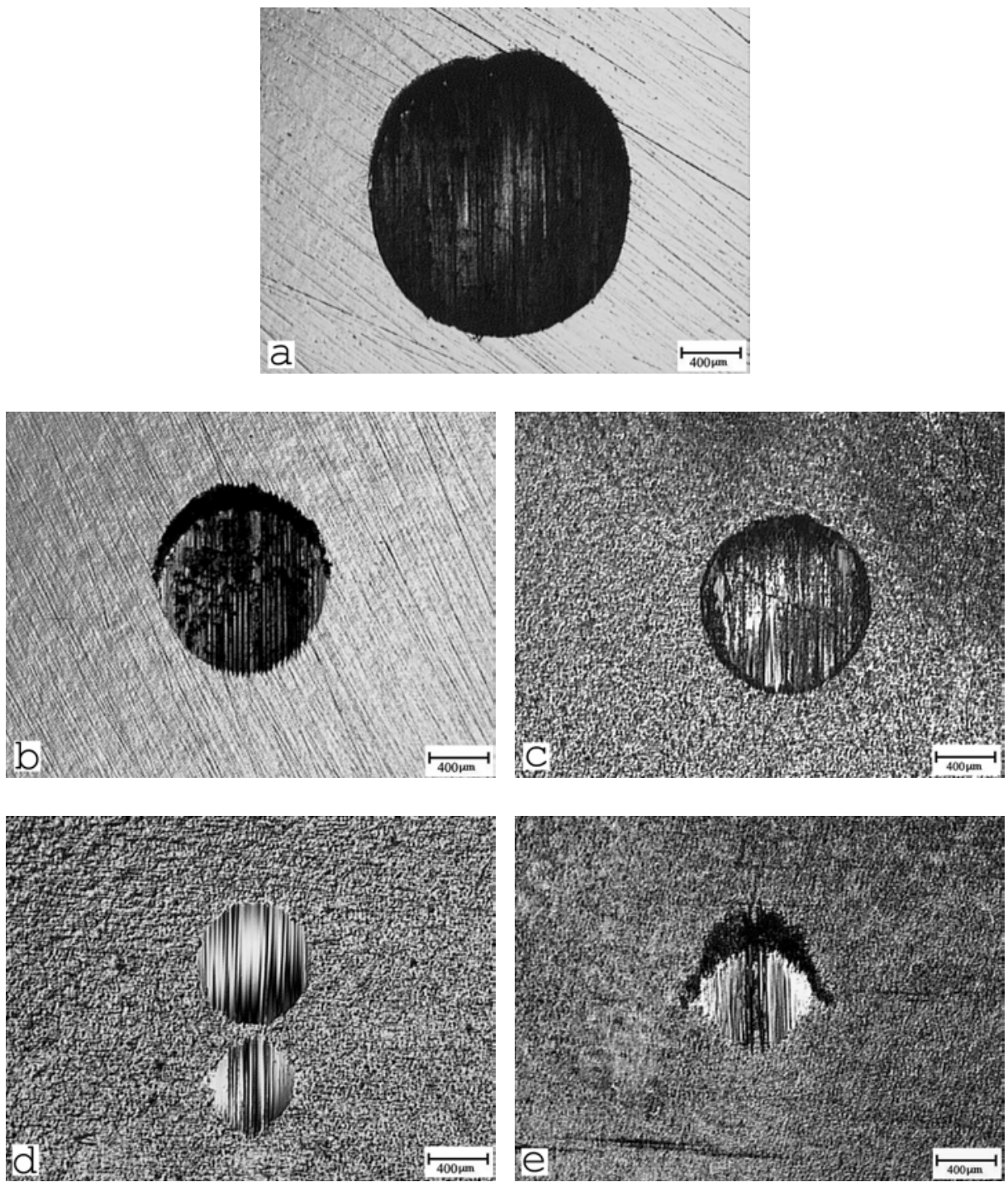

Figura 4.62 - Calotas formadas no aço AISI H13 após ensaio de desgaste em micro-escala, para uma distância de deslizamento de $177 \mathrm{~m}$. (a) Temperado/revenido, (b) Ionitretado, (c) Boretado (Fe-Ti), (d) Revestido com NbC (mostra-se também uma calota para uma distância de deslizamento de $118 \mathrm{~m}$ ), (e) revestido com VC. 
Verifica-se que todas as camadas apresentaram calotas de desgaste menores do que o substrato, destacando-se as camadas de NbC e VC (Fig. 4.62d e 4.62e). As camadas nitretada e boretada (Figs. 4.62 b e c), apresentaram calotas com tamanhos semelhantes.

As curvas de desgaste do substrato do aço AISI D2 temperado e revenido e dos diferentes tipos de camadas produzidas no mesmo são mostradas na figura 4.63. Observa-se também neste caso, que as amostras revestidas exibiram desempenhos ao desgaste muito superiores ao do substrato. Os menores volumes de desgaste foram observados nas camadas de carbonetos, devido provavelmente aos seus maiores valores de durezas. No caso das camadas de boretos verifica-se que a camada constituída predominantemente de FeB apresentou desempenho superior ao da camada com predominância de $\mathrm{Fe}_{2} \mathrm{~B}$.

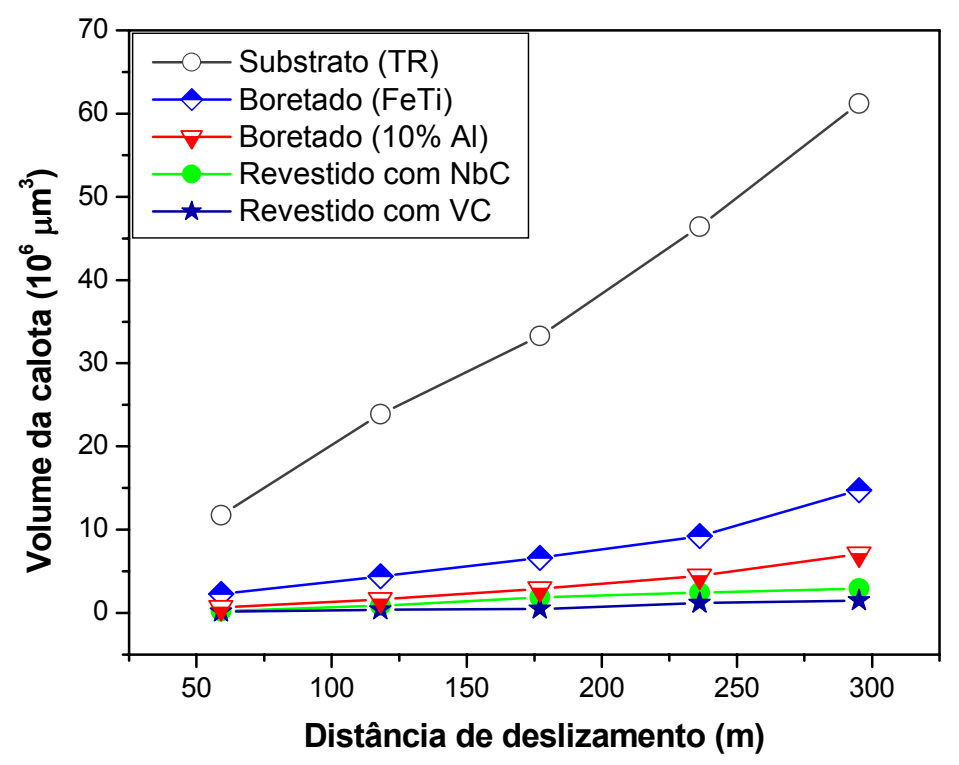

Figura 4.63 - Curvas de desgaste em micro-escala para o aço AISI D2: temperado/revenido (TR) e revestido com camadas de nitretos, carbonetos e boretos. 
Na figura 4.64 são mostradas as calotas de desgaste produzidas no aço AISI D2 e nas suas camadas, para uma distância de deslizamento de $177 \mathrm{~m}$, onde se constata que as menores calotas de desgaste foram as das camadas de $\mathrm{NbC}$ e VC (Figs. 4.64d e 4.64e), seguidas pelas camadas de boretos (4.64b e 4.64c). A calota formada no substrato foi muito maior do que as produzidas nas camadas.
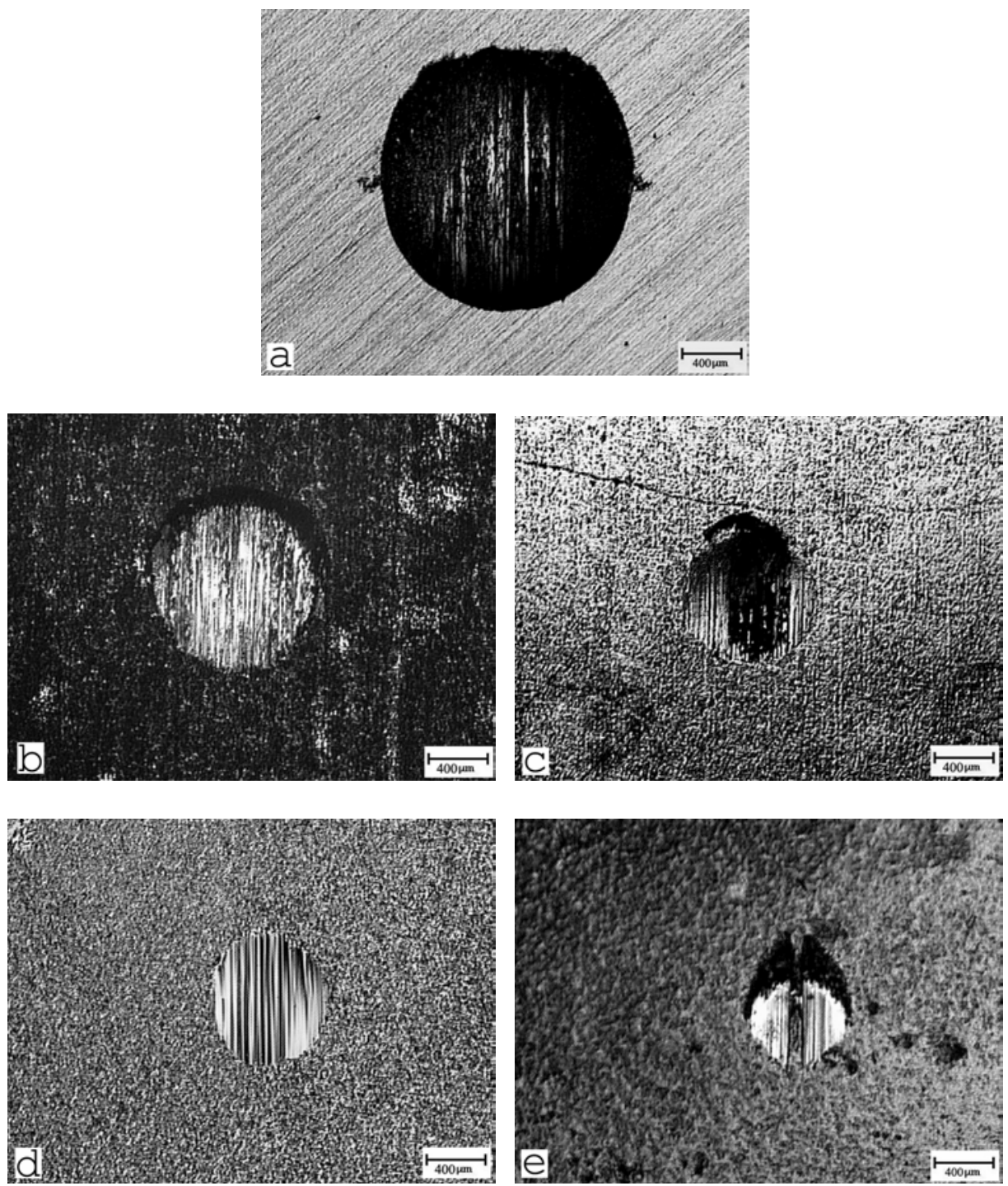

Figura 4.64 - Calotas formadas no aço AISI D2 após ensaio de desgaste em microescala, para uma distância de deslizamento de $177 \mathrm{~m}$. (a) Temperado/revenido, (b) Boretado (Fe-Ti), (c) Boretado (10\%Al), (d) Revestido com NbC, (e) revestido com VC. 
As resistências ao desgaste elevadas das camadas de carbonetos e de boretos devem-se às suas durezas elevadas e aos seus baixos coeficientes de atrito (Arai e Harper, 1991; Sinha, 1991). As propriedades tribológicas vantajosas das camadas de VC e Fe-B foram também reportadas por Wang (1997), Diebel et al. (2001) e Martini et al. (2004-a).

\subsection{Avaliação das superfícies de desgaste}

$\mathrm{Na}$ figura 4.65 apresentam-se as superfícies de desgaste das calotas obtidas em camadas de carbonetos e de boretos.

Embora os ensaios tenham sido realizados sem adição de abrasivo, registrou-se a presença de riscos paralelos e de algumas partes lisas nas superfícies de desgaste, evidenciando o desgaste abrasivo. Partículas oriundas da camada e da esfera podem mudar o modo de desgaste de adesivo para abrasivo. De acordo com Adachi e Hutchings (2003), os sulcos paralelos (desgaste por riscamento ou a dois corpos) devem-se a ação micro-cortante das partículas abrasivas que se fixam na esfera e são arrastadas através da superfície de contato, enquanto a superfície lisa (abrasão rolante ou a três corpos) é formada pela ação de muitas partículas pequenas rolando através da zona de contato. Bose e Wood (2005) também afirmaram que significativas marcas de riscamento podem ser causadas pela ação das partículas de desgaste aderidas à esfera.

As partículas abrasivas, que podem ser oriundas das camadas ou da esfera (o carboneto de cromo $\mathrm{Cr}_{3} \mathrm{C}_{2}$ apresenta durezas de 1350 a $2280 \mathrm{HV}$ ), são provavelmente, as responsáveis pela formação das ranhuras, como um resultado de suas elevadas durezas. As camadas de carbonetos apresentaram durezas na faixa de 2300 a $2500 \mathrm{HV}$ enquanto as durezas das camadas de boretos estiveram entre 1600 e $1750 \mathrm{HV}$, aproximadamente. 

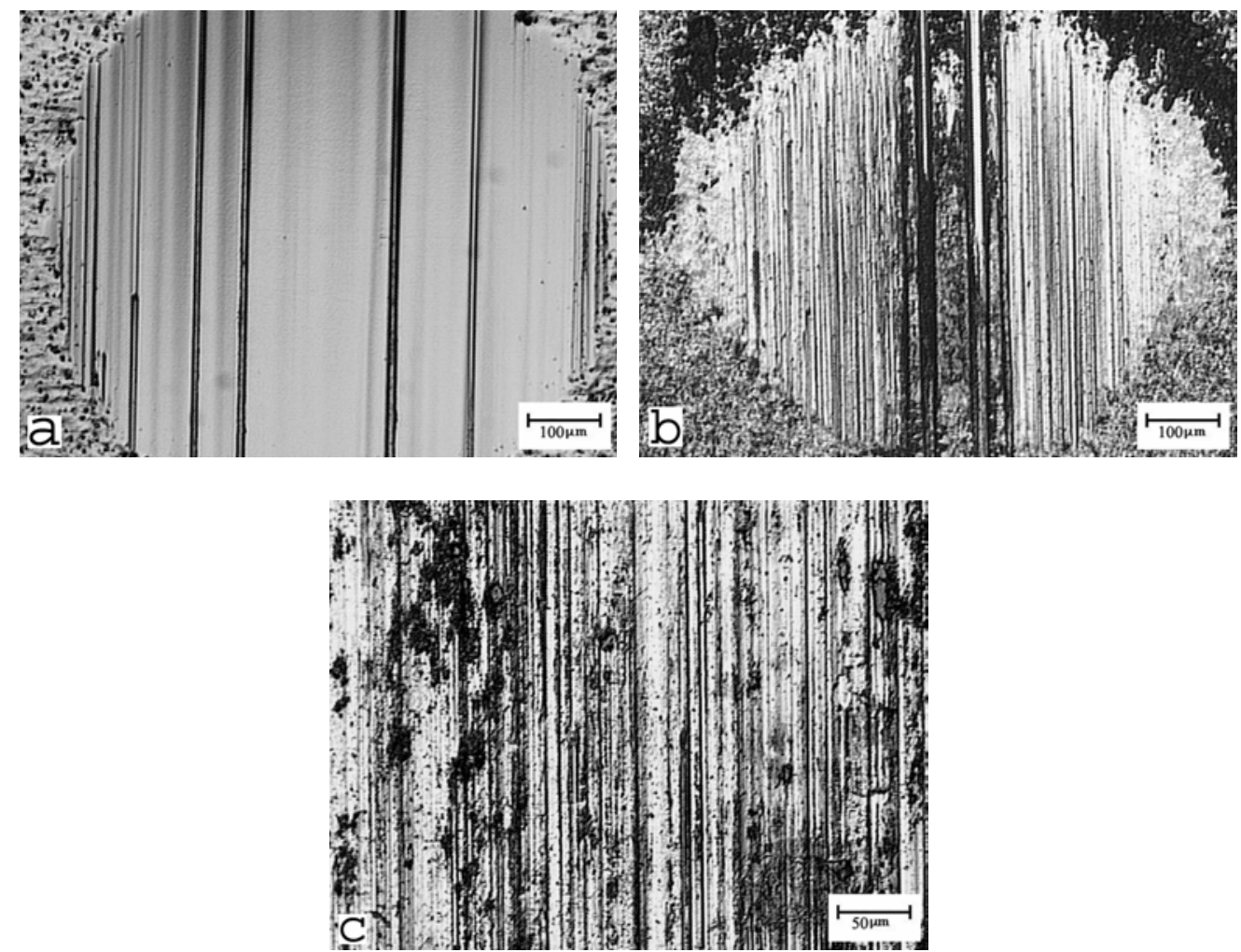

Figura 4.65 - Superfícies de desgaste das camadas, obtidas para uma distância de deslizamento de 177m: (a) H13 com NbC; (b) H13 com VC; (c) D2 boretado, no banho contendo $10 \% \mathrm{Fe}-\mathrm{Ti}+5 \% \mathrm{Al}$.

As superfícies de desgaste foram analisadas também por microscopia eletrônica de varredura (MEV), com análise química pontual por EDS. Avaliou-se um ponto da superfície da amostra, fora da calota, para ser comparado com os resultados das análises realizadas em pontos da superfície de desgaste das calotas.

Na figura 4.66a mostra-se a micrografia eletrônica da superfície de desgaste do aço AISI H13 temperado e revenido (substrato), obtida para uma distância de deslizamento de $177 \mathrm{~m}$. Os pontos 1 e 2 indicam onde foram realizadas as análises por EDS, cujos espectros são mostrados na figura 4.65b. Pode-se observar que os espectros são iguais, com a presença de $\mathrm{Fe}, \mathrm{Cr}$, Mo, $\mathrm{Si}$ e $\mathrm{V}$, que são os constituintes do aço $\mathrm{H} 13$. 

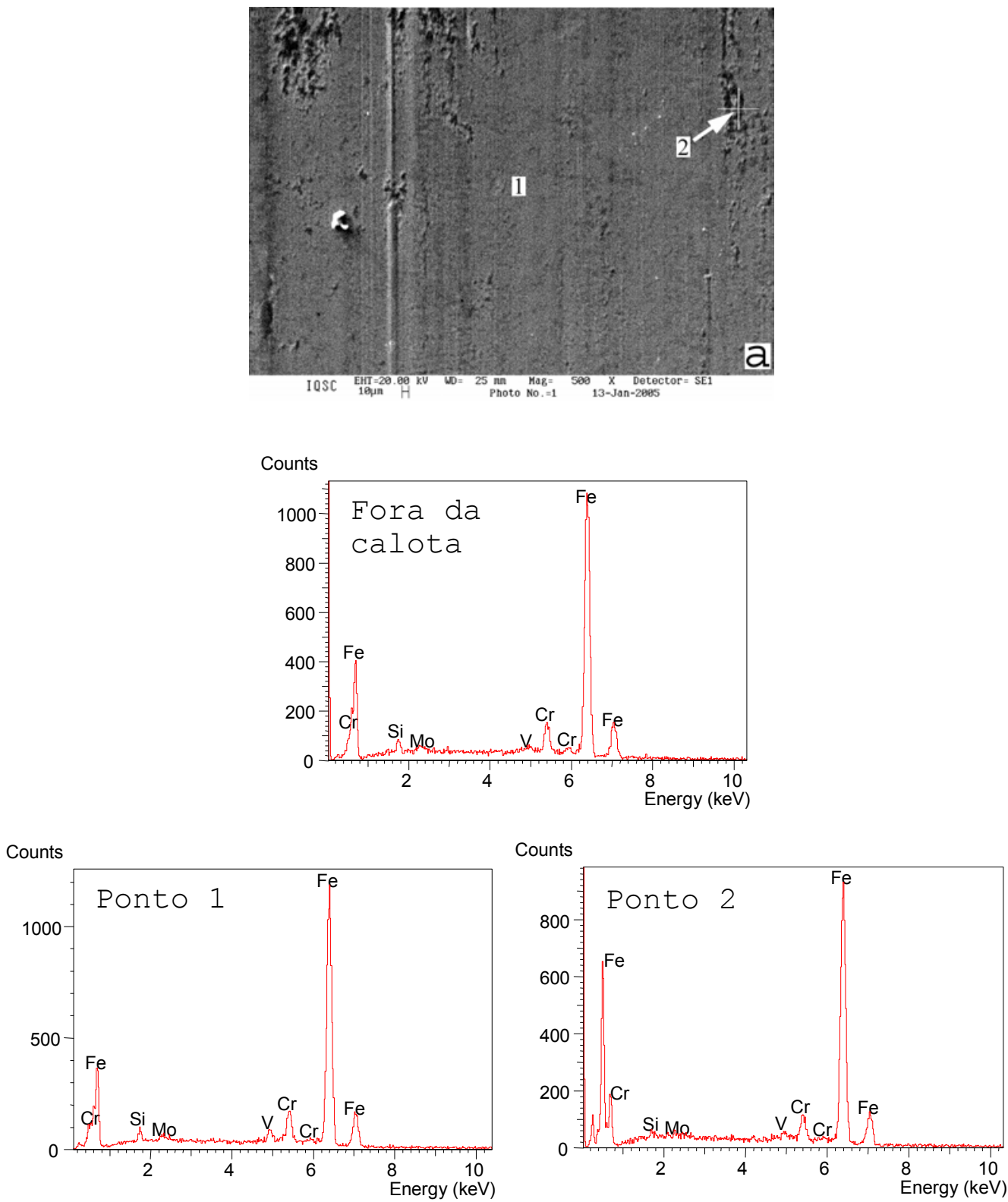

(b)

Figura 4.66 - (a) MEV e (b) EDS pontual da superfície de desgaste no aço AISI H13 temperado e revenido (substrato). Distância de deslizamento: $177 \mathrm{~m}$.

Nas figuras 4.67 e 4.68 são apresentados as micrografias eletrônicas e os resultados das análises por EDS das calotas de desgaste obtidas nas camadas de $\mathrm{NbC}$, nos aços $\mathrm{H} 13$ e D2, respectivamente. Nos dois casos, os resultados são semelhantes em todos os pontos analisados, detectando-se se a existência apenas 
de nióbio, que é o constituinte da camada, juntamente com o carbono. Nos pontos analisados não existe massa aderida.
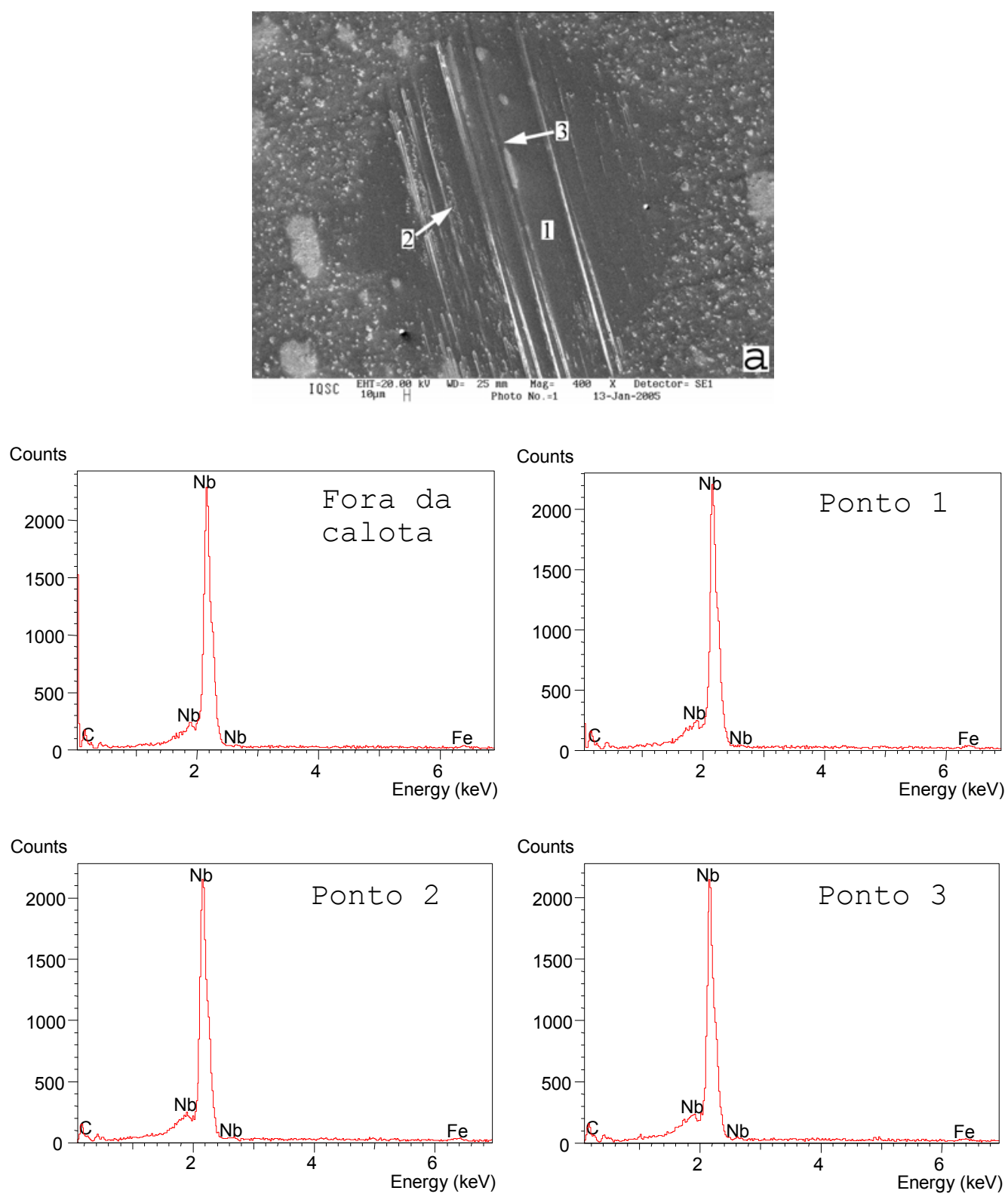

(b)

Figura 4.67 - (a) MEV e (b) EDS pontual da superfície de desgaste da camada de NbC. Substrato: aço H13. Distância de deslizamento: 236m. 

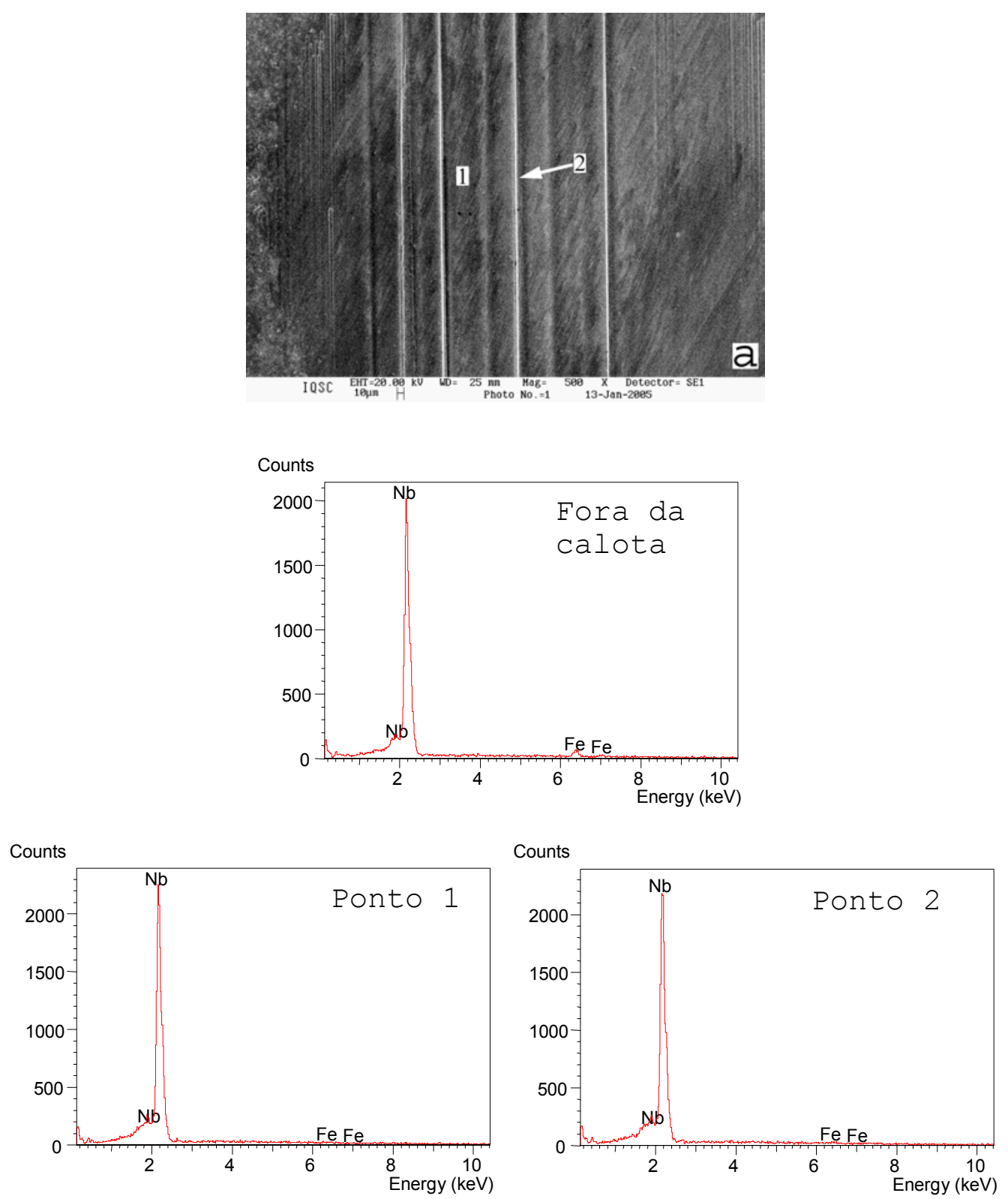

(b)

Figura 4.68 - (a) MEV e (b) EDS pontual da superfície de desgaste da camada de NbC. Substrato: aço D2. Distância de deslizamento: $177 \mathrm{~m}$.

As micrografias eletrônicas da calota de desgaste produzida na camada de VC obtida no aço AISI H13 são apresentadas nas figuras 4.69a e 4.69b (Pág. 107). No ponto $4(4.69 \mathrm{~b})$ verifica-se a presença de um material aderido à superfície de desgaste. Analisando-se os espectros de EDS (Fig. 4.69c) constata-se que 
praticamente não há diferença entre os pontos 1, 2 e 3, e fora da calota. Em relação ao ponto 4 registra-se o surgimento de um pico de elevada intensidade relativo ao Fe, indicando massa desse elemento aderida à superfície de desgaste (figura 4.69b), sendo provavelmente oriunda da esfera.

$\mathrm{Na}$ figura 4.70a (pág. 108) apresenta-se a micrografia eletrônica da superfície de desgaste para uma camada de boretos obtida no aço AISI H13, e na figura $4.70 \mathrm{~b}$ encontram-se os resultados das análises de EDS. Nos pontos 2 e 3 da micrografia destaca-se a presença de material aderido à superfície de desgaste. Nestes pontos, ao se analisar os espectros de EDS (figura 4.70b), observa-se um aumento na intensidade de um dos picos do $\mathrm{Fe}$, comparativamente com o ponto analisado fora da calota, indicando que o material aderido provavelmente é constituído de ferro, proveniente da esfera.

$\mathrm{Na}$ avaliação da camada de boreto obtida no aço AISI D2, a calota de desgaste analisada se apresentou lisa, sem a presença de material aderido, conforme mostrado na figura 4.71a (pág. 109). Os resultados de EDS obtidos nos pontos 1 e 2, e fora da calota, não apresentaram diferenças significativas (Fig. 4.71b). 

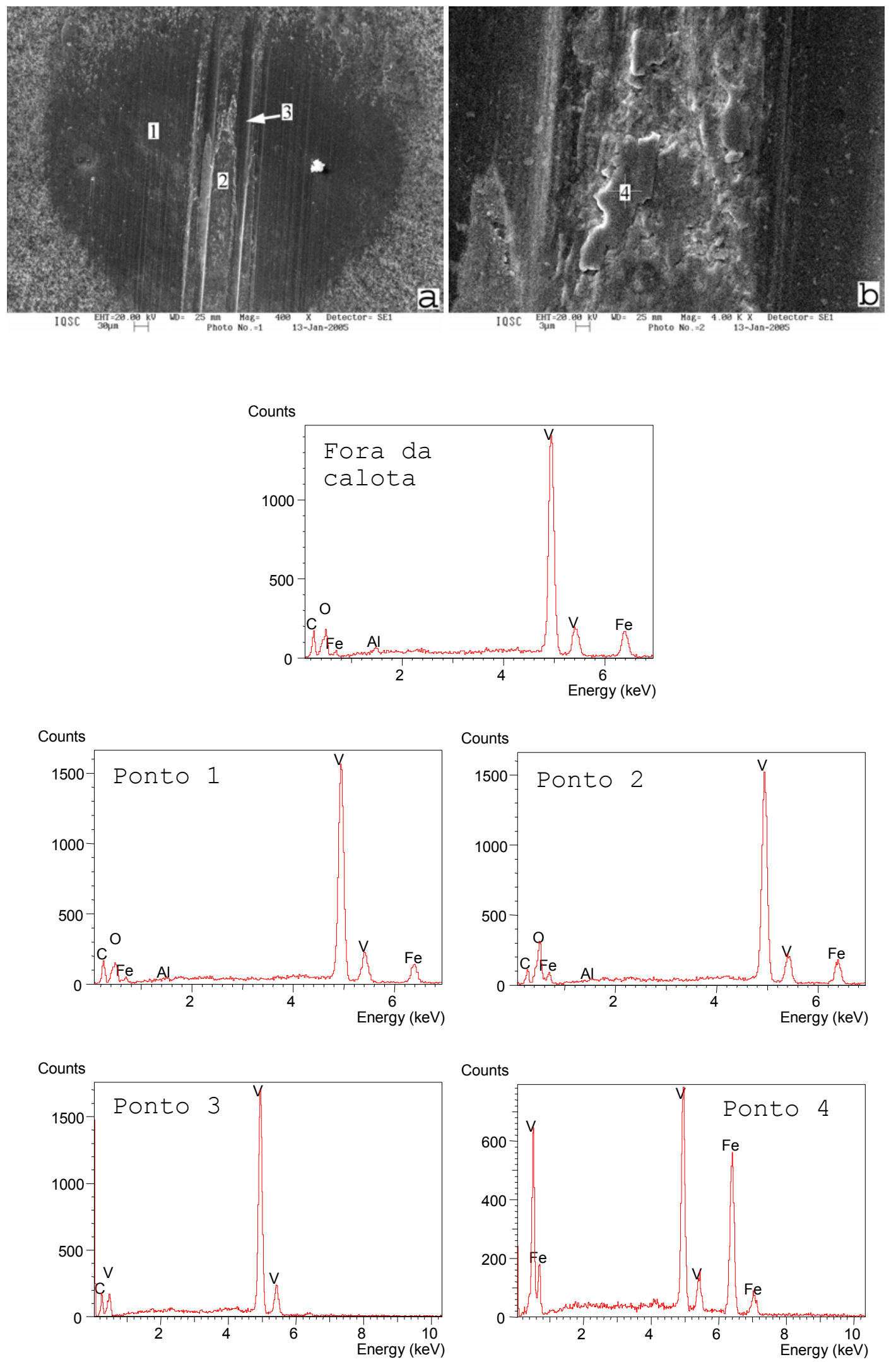

(c)

Figura 4.69 - (a) e (b) MEV e (c) EDS pontual da superfície de desgaste da camada de VC. Substrato: aço H13. Distância de deslizamento: $177 \mathrm{~m}$. 

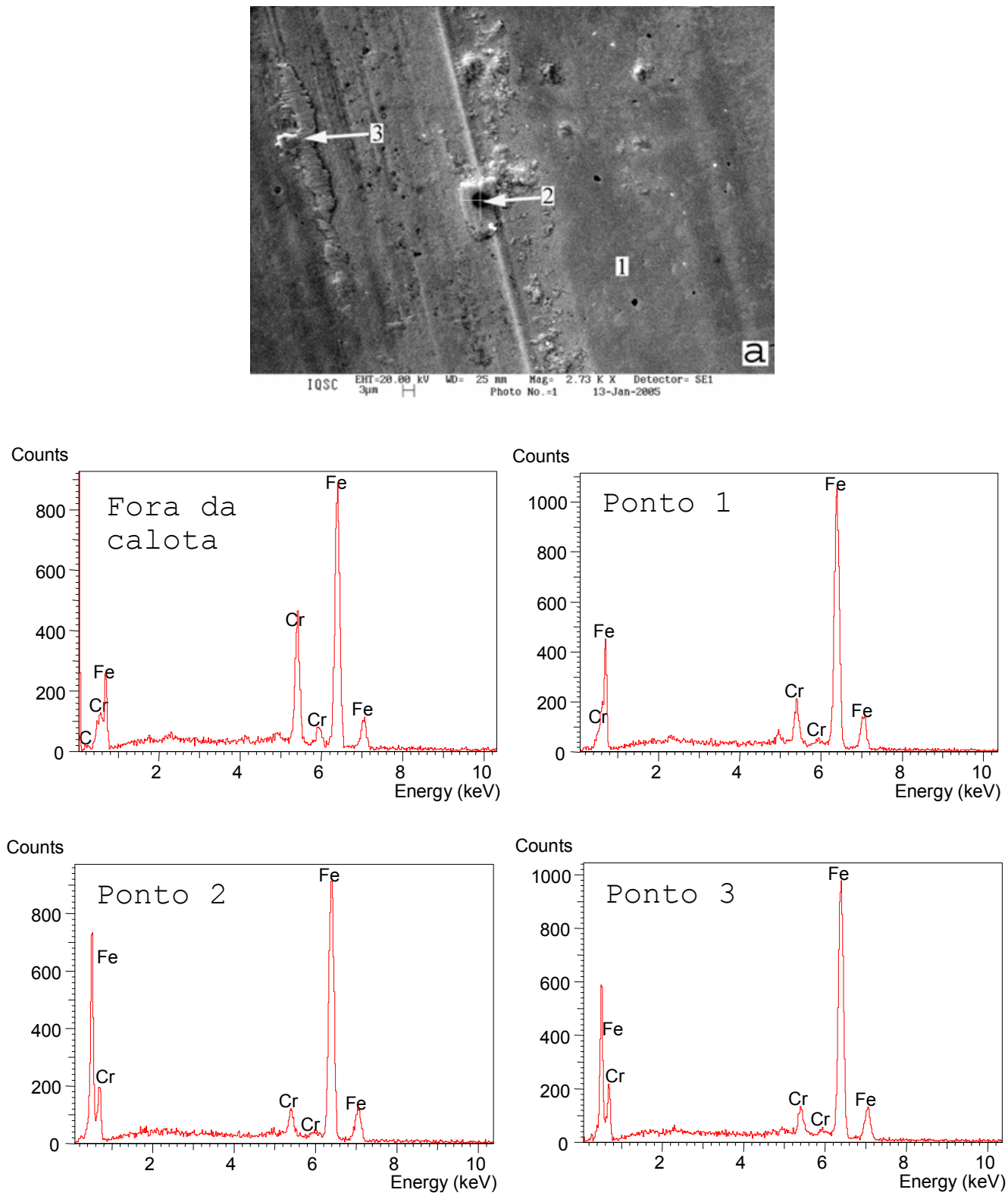

(b)

Figura 4.70 - (a) MEV e (b) EDS pontual da superfície de desgaste da camada de boreto. Substrato: aço H13. Banho: $10 \% \mathrm{Fe}-\mathrm{Ti}+5 \% \mathrm{Al}$. Distância de deslizamento: $177 \mathrm{~m}$. 

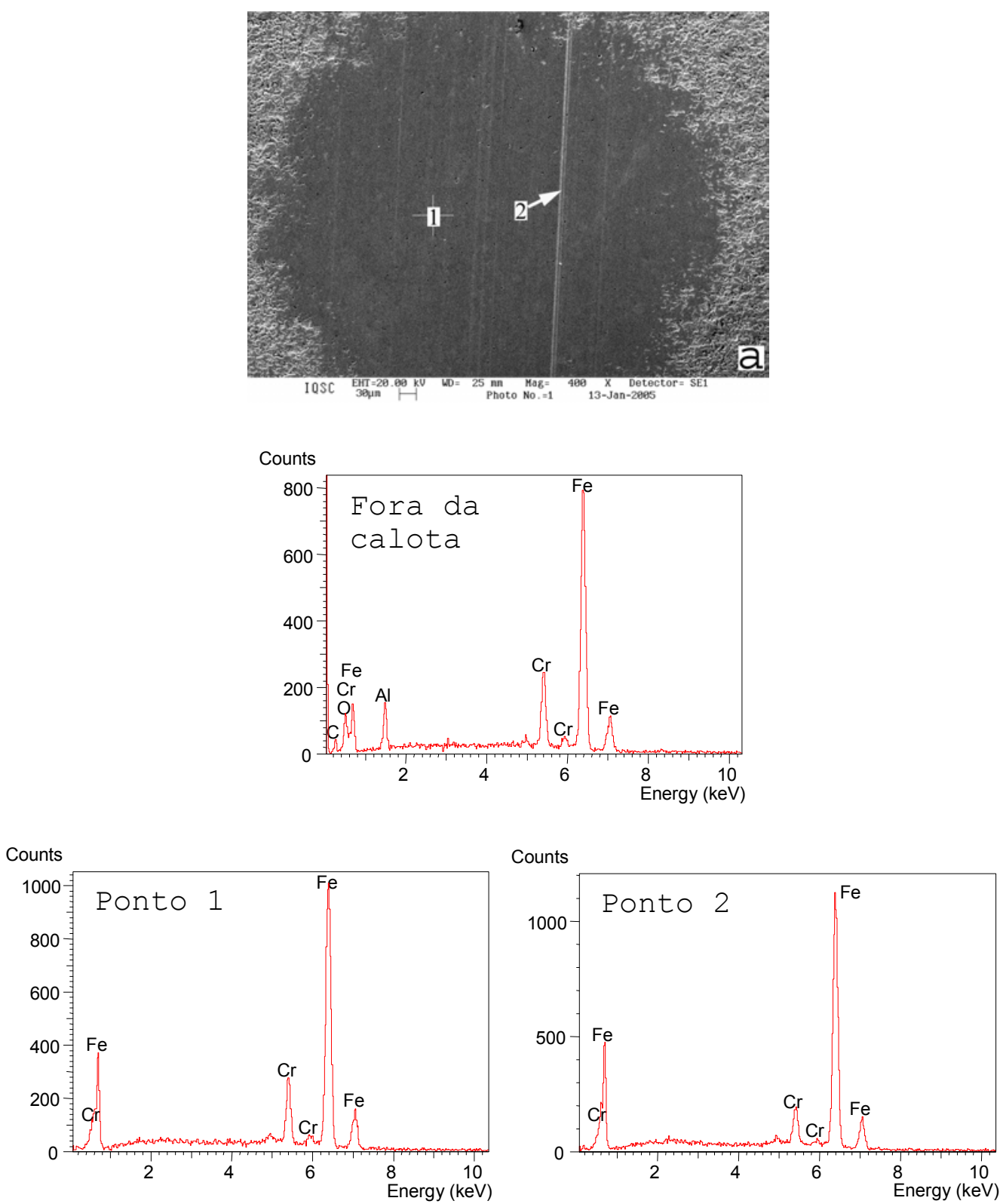

(b)

Figura 4.71 - MEV e EDS pontual da superfície de desgaste da camada boretada. Substrato: aço D2. Banho: 10\%Fe-Ti + 5\%Al. Distância de deslizamento: $177 \mathrm{~m}$. 


\section{CONCLUSÕES}

O presente trabalho teve como objetivo a produção de camadas de carbonetos e de boretos nos aços AISI H13 e D2, por meio de tratamentos termo-reativos em banhos de bórax, e as suas caracterizações, principalmente em termos da determinação de suas composições químicas e avaliação de suas resistências ao desgaste em micro-escala, sem o uso de abrasivos e com carga elevada. Diante dos resultados, chegou-se às seguintes conclusões:

- Os tipos das camadas obtidas foram dependentes das composições dos banhos.

- Nos banhos contendo Fe-Nb/Al as camadas obtidas nos dois aços constituíram-se de $\mathrm{NbC}$, enquanto nos banhos com adição de Fe-V/Al, formaram-se camadas de VC. Estas camadas apresentaram espessuras regulares e interfaces planas com os substratos. As camadas formadas no aço AISI D2 foram mais espessas, devido ao seu teor de carbono mais elevado.

- Nos banhos contendo Fe-Ti/Al, as camadas obtidas constituíram-se de boretos, indicando que o titânio agiu como um redutor químico no banho de bórax. Camadas de boretos também foram produzidas nos casos dos banhos com adição apenas do alumínio, em teores de 10 e 15\%Al. As camadas boretadas, constituídas principalmente de $\mathrm{Fe}_{2} \mathrm{~B}$ e $\mathrm{FeB}$, apresentaram interfaces irregulares com os substratos.

- Para o caso do banho misto contendo (Fe-Nb + Fe-Ti)/Al, as camadas constituíram-se unicamente de $\mathrm{NbC}$, sem a formação de carbonetos complexos. 
- Todas as camadas apresentaram excelentes aderências aos substratos, verificadas por meio de indentação Vickers nas interfaces camada/substrato, não tendo ocorrido o aparecimento de trincas ou o destacamento das camadas.

- Os níveis de dureza das camadas de boretos $(\sim 1600-1750 \mathrm{HV})$ e de carbonetos $(\sim 2300-2500 \mathrm{HV})$, foram de aproximadamente 2,5 e 3,5 vezes a dureza dos substratos, respectivamente.

- As resistências ao desgaste em micro-escala das camadas de carbonetos e de boretos foram muito superiores às dos substratos, destacando-se as camadas de carboneto de $\mathrm{Nb}$ e de $\mathrm{V}$, o que se atribui aos seus níveis de dureza mais elevados.

- O ensaio de desgaste em micro-escala, sob carga elevada e sem uso de abrasivo, implicou em desgaste do tipo adesivo-abrasivo, verificado na aparência das calotas de desgaste, com o registro de sulcos paralelos e regiões polidas, que é uma característica de desgaste abrasivo, e em alguns casos, com a presença de material aderido à superfície, evidenciando mecanismos adesivos de desgaste. 


\section{REFERÊNCIAS BIBLIOGRÁFICAS}

ADACHI, K.; HUTCHINGS, I.M. Wear-mode mapping for the micro-scale abrasion test. Wear, v.255, p.23-29, 2003.

ADACHI, K.; HUTCHINGS, I.M. Sensitivity of wear rates in the micro-scale abrasion test to test conditions and materials hardeness. Wear, v.258, p.318-321, 2005.

ALLSOPP, D.N.; HUTCHINGS, I.M. Micro-scale abrasion and scratch response of PVD coatings at elevated temperatures. Wear, v.251, p.1308-1314, 2001.

ARAI, T. Carbide coatings process by use of molten borax bath in Japan. J. Heat Treat., v.1, n.5, p.15-22, 1979.

ARAI, T. Carbide coating process by use of molten borax bath. Wire, v.31, n.3, p.102-104, 1981.

ARAI, T. Tool materials and surface treatments. J. Mater. Proc. Technol., v.35, p.515-528, 1992.

ARAI, T.; FUJITA, H.; SUGIMOTO, Y; OHTA, Y. Diffusion carbide coatings formed in molten borax systems. J. Mater. Eng., v.9, n.2, p.183-189, 1987.

ARAI, T.; FUJITA, H.; SUGIMOTO, Y; OHTA, Y. Vanadium carbonitride coating by immersing into low temperature salt bath. In: Heat Treating and Surface Engineering: New Technology and Practical Applications. George Krauss. ASM International, USA, 1988, pp. 49-53.

ARAI, T.; HARPER, S. Thermoreactive deposition/diffusion process. ASM Handbook, ASM International, Materials Park, Ohio, v.4, p.448-453, 1991.

ARAI, T.; MORIYAMA, S. Growth behavior of vanadium carbide coatings on steel substrates by a salt bath immersion coating process. Thin Solid Films, v.249, p.54-61, 1994.

ASKELAND, D. The Science and Engineering of Materials. Boston, PWS Publishing Company, 3.ed., 1994.

BADISCH, E.; MITTERER, C. Abrasive wear of high speed steels: Influence of abrasive particles and primary carbides on wear resistance. Tribology International, v.36, p.765-770, 2003.

BATISTA, J.C.A.; JOSEPH, M.C.; GODOY, C.; MATTHEWS, A. Micro-abrasive wear testing of PVD TiN coatings on untreated and plasma nitrided AISI H13 steel. Wear, v.249, p.971-979, 2002. 
BAYER, R.G. Wear testing. Metals Handbook, ASM International, Materials Park, $\mathrm{OH}, \mathrm{v} .8$, p.601-608, 1985.

BOSE, K.; WOOD, R.J.K. Optimum tests conditions for attaining uniform rolling abrasion in ball cratering tests on hard coatings. Wear, v.258, p.322-332, 2005.

BUNSHAH, R.F. PVD e CVD coatings. ASM Handbook, ASM International, Materials Park, Ohio, v.18, p.840-849, 1992.

CABEO E. C. et al., Plasma-assisted boriding of industrial components in a pulse d.c. glow discharge. Surf. Coat. Technol., v.116-119, p.229-233, 1999.

CHEN, F.-S.; LEE, P.-Y.; YEH, M.-C. Themal reactive deposition coating of chromium carbide on die steel in a fluidized bed furnace. Materials Chemistry and Physics, v.53, p.19-27, 1998.

CHEN, H.; Xu, C.; Zhou, Q.; Hutchings, I.M.; Shipway, P.H.; Liu, J. Micro-scale abrasive wear behaviour of HVOF sprayed and laser-remelted conventional and nanostructured WC-Co coatings. Wear, v.258, p.333-338, 2005.

CHICCO, B.; BORBIDGE, W.E.; SUMMERVILLE, E. Experimental study of vanadium carbide and carbonitride coatings. Mater. Sci. Eng. A, v.266, p.62-72, 1999.

CHICCO, B.; BORBIDGE, W.E.; SUMMERVILLE, E. Engineering the subsurface of borided AISI H13 steel. Surf. Eng., v.14, n.1, p.25-30, 1998.

CHILD, H.C.; PLUMB, S.A.; McDERMOTT, J.J. Carbide layer formation on steels in fused borax baths. Proceeding of the Heat Treatment'84, The Metals Society, p.5.1-5.7, 1984.

DIEBEL, J. R.; SRIDHARAN, K.; BULL, S. J. Evaluation of four commercially produced surface treatments. J. Mater. Eng. Perform., v.10, n.3, P. 263-269, 2001.

EYRE, T.S. Friction and wear control in industry. Metals and Materials, v.7, n.3, P. 143-148, 1991.

GEE, M.G. et al. Progress towards standardization of ball cratering. Wear, v.255, p.1-13, 2003.

GENEL, K.; OZBEK, I.; BINDAL, C. Kinetics of boriding of AISI W1 steel. Mater. Sci. Eng. A, v.347, p.311-314, 2003.

HOLMBERG, K. A concept for friction mechanisms of coated surfaces. Surf. Coat. Technol., v.56, p.1-10, 1992.

HOLLECK, H. Material selection for hard coatings. J. Vaccum Science Technology A, v.4, n.6, p.2661-2669, 1986.

JONES, A. H. Micro-scale abrasive wear of silicon nitride, sialon-TiB2 composites and D2 tool steel using a multiple load method. Wear, v. 258, p. 942-952, 2005. 
KHOEE, S.M.M.; ATA, A.; GECKINLI, A.E.; BOZKURT, N. VC \& NbC coating on DIN 115CrV3 steel in molten borax bath. Mater. Sci. Forum, v.163-165, p.627632, 1994.

KING, P.C.; REYNOLDSON, R.W.; BROWNRIGG, A.; LONG, J.M. Fluidized bed $\mathrm{CrN}$ coating formation on prenitrocarburized plain carbon steel. J. Mater. Eng. Perform., v.13(4), p.431-438, 2004.

KULKA, M.; PERTEK, A. The importance of carbon content beneath iron borides after boriding of chromium and nickel-based low-carbon steel. Applied Surface Science, v.214, p.161-167, 2003.

LEE, S.Y.; CHUNG, J.W.; KIM, K.B.; HAN, J.G., KIM, S.S. Duplex plasma surface treatment process on mild steel ans high alloyed tool steel, Surf. Coat. Technol., v.86-87, p. 325-331, 1996.

MARTINI, C.; PALOMBARINI, G.; POLI, G.; PRANDSTRALLER, D. Sliding and abrasive wear behavior of boride coatings. Wear, v.256, p.608-613, 2004-a.

MARTINI, C.; PALOMBARINI, G.; CARBUCICCHIO, M. Mechanism of thermochemical growth of iron borides on iron. J. Mater. Sci., v.39, p.933-937, 2004-b.

MATIAšOVSKÝ, K.; CHRENKOVÁ-PAUčÍROVÁ, M.; FELLNER, P.; MAKTA, M. Electrochemical and thermochemical boriding in molten salts. Surf. Coat. Technol., v.35, p.133-149, 1988.

MUÑOZ RIOFANO; CASTELETTI,L. C. Influência dos parâmetros de nitretação por plasma na dureza e na resistência ao desgaste por abrasão da camada nitretada em anéis de pistão. In: $9^{\circ}$ Encontro da Sociedade Portuguesa de Materiais, 1999, Guimarães. v. 1, p. 29-33.

OLIVEIRA, C.K.N.; CASTELETTI,L. C. Boretação do aço AISI H13 por deposição termo-reativa em banho de sal. In: Congresso Anual da Associação Brasileira de Metalurgia e Materiais-Internacional, 2004, São Paulo. Anais do 59º Congresso Anual da Associação Brasileira de Metalurgia e MateriaisInternacional, 2004. p. 3920-3927.

ÖZBEK, I.; KONDUK, B.A.; BINDAL, C.; UCISIK, A.H, Characterization of borided AISI 316L stainless steel implant. Vacuum, v.65, p. 521-525, 2002.

OZBEK, I.; BINDAL, C. Mechanical properties of boronized AISI W4 steel. Surf. Coat. Technol., v.154, p. 14-20, 2002.

PALOMBARINI, G.; CARBUCICCHIO, M. Influence of carbon on the chromium redistribution when boriding iron alloys. J. Mater. Sci. Lett., v.12, p. 797-798, 1993.

PLUMB, S. Toyota diffusion process shows advantages. Metallurgia, v.52, p. 59$61,1985$.

QUAEYHAEGENS, C.; KERKHOFS, M.; STALS, L.M.; VAN STAPPEN, M. Promising developments for new applications, Surf. Coat. Technol., v.80, p. 181-184, 1996. 
RUTHERFORD, K.L.; HUTCHINGS, I.M. A micro-abrasive wear test, with particular application to coated system. Surf. Coat. Technol., v.79, p.231-239, 1996.

RUTHERFORD, K.L.; HUTCHINGS, I.M. Theory and application of a micro-scale abrasive wear test. J. of Testing and Evaluation, v.25, n.2, p.250-260, 1997.

SELÇUK, B.; IPEK, R.; KARAMIS, M.B.; KUZUCU, V. An investigation on surface properties of treated low carbon and alloyed steels (boriding and carburizing). J. Mater. Proc. Technol., v.103, p.310-317, 2000.

SEN, S.; OZBEK, I.; SEN, U.; BINDAL, C. Mechanical behavior of borides formed on borided cold work tool steel. Surf. Coat. Technol., v.135, p.173-177, 2001.

SEN, S.; SEN, U.; BINDAL, C. The growth kinetics of borides formed on boronized AISI 4140 steel. Vacuum, v.77, n.2, p.195-202, 2005-a.

SEN, S.; SEN, U.; BINDAL, C. An approach to kinetic study of borided steels. Surf. Coat. Technol., v.191, n.2-3, p.274-285, 2005-b.

SEN, U. Kinetics of niobium carbide coating produced on AISI 1040 steel by thermoreactive deposition technique. Materials Chemistry and Physics, v.86, p.189194, 2004.

SEN, U.; SEN, S. The fracture toughness of borides formed on boronized cold work tool steels. Mater. Character., v.50, p. 261-267, 2003.

SHIPWAY, P.H. The role of test conditions on the micro-abrasive wear behaviour of soda-lime glass. Wear, v.233-235, p. 191-199, 1999.

SIDKY, P.S.; HOCKING, M.G. Review of inorganic coatings and coating processes for reducing wear and corrosion. British Corrosion Journal, v.34, n.3, p. 171183, 1999.

SINHA, A. K. Boriding (Boronizing). ASM Handbook, ASM International, v.4, p. 437-447, USA, 1991.

SIRVIO, E.H.; SULONEN, M. Abrasive wear of ion-plated titanium nitride coatings on plasma-nitrided steel surfaces. Thin Solid Films, v.96, p. 93, 1982.

SRICHAROENCHAI, P.; PORNNIMITTHUM, S.; BHANDHUBANYONG, P. Coating of tool steels with niobium carbide by TRD process. Proceeding of the $1^{\text {st }}$ International Automotive Heat Treatment Conference, ASM International, p.391-394, USA, 1998.

STAIA, M.H. et al. Application of ball cratering method to study abrasive wear. Surf. Eng., v.14, n.1, p.49-54, 1998.

STACHOWIAK, G.W.; BATCHERLOR, A.W. Engineering Tribology. Amsterdam, Elsevier Science Publishers B.V., 1993.

STACHOWIAK, G.B.; STACHOWIAK, G.W. Wear mechanisms in ball-cratering tests with large abrasive particles. Wear, v.256, p. 600-607, 2004. 
STACK, M.M.; MATHEW, M. Micro-abrasion transitions of metallic materials. Wear, v.255, p. 14-22, 2003.

SUBRAMANIAN, C.; STRAFFORD, K. N.; WILKS, T. P.; WARD, L. P. On the design of coating systems: metallurgical and other considerations. J. Mater. Proc. Technol., v.56, p.385-397, 1996.

SUBRAMANIAN, C.; STRAFFORD, K.N. Review of multicomponent and multilayer coatings for tribological applications. Wear, v. 165, p. 85-95, 1993.

TOKYO HEAT TREATING COMPANY LTD. Carbide coatings process: TD process. Tokyo, s.n.t.

TOPUZ, A.; TOPLU, D. Chromium carbide coating of steels by thermoreative diffusion process, Prakt. Metallogr., v. 36, p. 5-11, 1999.

TREZONA, R.I.; ALLSOPP, D.N.; HUTCHINGS, I.M. Transitions between two-body abrasive wear: influence of test conditions in the microscale abrasive wear test. Wear, v.225-229, p.205-214, 1999.

TREZONA, R.I.; HUTCHINGS, I.M. Three-body abrasive wear testing of soft materials. Wear, v.233-235, p.209-221, 1999.

TYLCZAK, J.H. Abrasive wear. ASM Handbook, ASM International, Materials Park, OH, USA, v.18, p. 185-190, 1992.

WALKOWICZ, J.; SMOLIK, J.; MIERNIK, K.; BUJAK, J. Duplex surface treatment of molds for pressure casting of aluminium, Surf. Coat. Technol., v. 97, p. 453464, 1997.

WANG, G.B. Wear mechanisms in vanadium carbide coated stees. Wear, v.212, p.25-32, 1997.

ZENG, X.T.; Zhang, S.; Muramatsu, T. Comparison of three advanced hard coatings for stamping applications, Surf. Coat. Technol., v.127, p. 38-42, 2000. 